$$
\begin{gathered}
\text { UNIVERZITET U BEOGRADU } \\
\text { FIZIČKIFAKULTET }
\end{gathered}
$$

M AR I J A M. PETKOVIĆ

\title{
PLAZMA ELEKTROLITIČKA
}

\section{OKSIDACIJA VENTILNIH METALA}

doktorska disertacija 
UNIVERSITY OF BELGRADE

FACULTY OF PHYSICS

MARIJA M. PETKOVIĆ

\section{PLASMA ELECTROLYTIC OXIDATION OF VALVE METALS}

Doctoral Dissertation

Belgrade, 2012 
Mentor doktorske disertacije:

dr Stevan Stojadinović, docent

Univerziteta u Beogradu Fizičkog fakulteta

Komisija za odbranu doktorske disertacije:

dr Stevan Stojadinović, docent Fizičkog fakulteta

dr Ljubiša Zeković, redovni profesor Fizičkog fakulteta

dr Rastko Vasilić, docent Fakulteta zaštite životne sredine, Edukons Univerzitet

Datum odbrane: 


\section{ZAHVALNICA}

Zahvaljujem se, pre svega, svom mentoru doc. dr Stevanu Stojadinoviću čije su dragocene sugestije, trud, podrška i nesebično zalaganje učinili da projekat izrade ove dotorske disertacije ostane ozbiljan, sveobuhvatan ali nikako težak.

Zahvaljujem se i doc. dr Rastku Vasiliću za ogroman doprinos u tumačenju eksperimentalnih rezultata i uvek novim idejama koje su usmeravale istraživački rad.

Veliku zahvalnost dugujem prof. dr Ljubiši Zekoviću koji je i pored mnogobrojnih obaveza kao dekan Fizičkog fakulteta, uvek pronalazio vremena i volje da mi pruži korisne savete i sugestije.

Zahvaljujem i svojim divnim kolegama: doc. dr Bećku Kasalici, mr Mirjani Sarvan, prof. dr Ivanu Belči i Zoranu Bokoru na nesebičnoj pomoći.

Zahvaljujem najtoplije i svoj porodici, pre svega sestri Vesni i bratu Vladimiru i dragim prijateljima: Goranu, Olgi, Aleksandri, Mariji i Jasmini na velikoj podršci i razumevanju.

Ovu doktorsku disertaciju posvećujem svojoj majci Snežani i ocu Miroljubu. 


\section{Plazma elektrolitička oksidacija ventilnih metala}

Ova doktorska disertacija bavi se proučavanjem fenomena Plazma Elektrolitičke Oksidacije (PEO) ventilnih metala (Al, Mg, Ti, Ta) i oksidnih slojeva koji se dobijaju u elektrolitima koji sadrže volfram, pre svega u 12-volframsilicijumskoj kiselini.

Primenom metoda optičke emisione spektroskopije i analize procesa u realnom vremenu, omogućeno je određivanje: temperature, elektronske gustine plazme, dimenzionalne distribucije i aktivne površine mikro pražnjenja.

Pokazano je da PEO procesi na svim ispitivanim metalima pokazuju tendenciju da se broj mikro pražnjenja smanjuje sa vremenom, a da površine poprečnih preseka mikro pražnjenja rastu. Sa porastom vremena PEO procesa broj kanala za pražnjenje se smanjuje, dok njihov dijametar raste i dolazi do povećanja hrapavosti oksidnih površina. Procenat aktivne površine istovremeno izložen događajima mikro pražnjenja takođe raste u početku PEO procesa, dostiže svoj maksimum, a potom polako opada.

Sve spektralne linije detektovane u optičko emisionim spektrima u toku PEO procesa pripadaju ventilnim metalima i jonskim i atomskim elementima prisutnim $u$ elektrolitu. Pored jasno izraženih atomskih i jonskih linija, u optičko emisionom spektru dobijenom tokom PEO procesa na magnezijumu, jasno je vidljiva i vibraciona traka $\mathrm{MgO}$ molekula, koja odgovara elektronskom prelazu sa pobuđenog $\mathrm{B}^{1} \Sigma^{+}$nivoa na osnovni elektronski nivo $\mathrm{X}^{1} \Sigma^{+}$. Na sličan način, u spektru dobijenom tokom PEO procesa na aluminijumu opaža se jaka vibraciona traka AlO sistema, koja odgovara elektronskom prelazu sa pobuđenog $\mathrm{B}^{2} \Sigma^{+}$nivoa na osnovni elektronski nivo $\mathrm{X}^{2} \Sigma^{+}$.

U slučaju PEO procesa na aluminijumu i magnezijumu, koristeći spektroskopske podatke dobijene za $\mathrm{AlO}, \mathrm{OH}$ i $\mathrm{MgO}$ trake, uz primenu kvantno-mehaničkih proračuna, određene su temperature plazme. Iz vibracionih traka $\mathrm{MgO}$ molekula procenjeno je da su temperature plazme $(11000 \pm 2000) \mathrm{K}$, dok su u slučaju podataka iz OH trake dobijene nešto niže vrednosti temperature $(3500 \pm 500) \mathrm{K}$. Iz analiza vibracione trake $\mathrm{AlO}$ molekula u slučaju PEO procesa u limunskoj kiselini procenjena temperatura je $(8000 \pm 2000) \mathrm{K}$. 
Oblik $\mathrm{H}_{\beta}$ linije, dobijen u toku PEO procesa na titanijumu i tantalu, se može pouzdano fitovati sa dva Lorencova profila. Iz poluširina fitovanih linija su dobijene dve elektronske koncentracije od $\sim 0.8 \cdot 10^{15} \mathrm{~cm}^{-3} \mathrm{i} \sim 2.1 \cdot 10^{16} \mathrm{~cm}^{-3}$. Ove dve elektronske koncentracije su bliske odgovarajućim elektronskim koncentracijama dobijenim iz spektralne analize $\mathrm{H}_{\beta}$ linije u toku PEO procesa na aluminijumu.

Posebna pažnja posvećena je istraživanju morfologije i hemijskog i faznog sastava oksidnih slojeva dobijenih PEO procesom na aluminijumu, titanijumu i tantalu sa idejom da se ispitaju novi, komercijalno prihvatljivi načini za dobijanje odgovarajućih bronzi. Bronze heteropoli kiselina su poznate po odličnim katalitičkim, poluprovodnim i antikorozivnim osobinama. Karakterizacija dobijenih oksidnih slojeva vršena je fizičko-hemijskim metodama: SEM-EDS mikro spektroskopijom, rentgenostrukturnom analizom, AFM mikroskopijom i Raman spektroskopijom.

U svim eksperimentima je pokazano da sadržaj volframa na površini raste sa trajanjem PEO procesa, dok sadržaj metala koji potiče od substrata opada. Kako se elementi iz elektrolita ugrađuju u toku PEO procesa u spoljnji sloj oksidne površine, to i sadržaj volframa raste. Oksidni slojevi su delimično kristalizovani i uglavnom se sastoje iz odgovarajućih oksida metala.

Ramanovi spektri oksidnih slojeva aluminijuma, titanijuma i tantala su slični referentnom Ramanovom spektru 12-silicijumvolframske kiseline izložene termalnom tretmanu na $550{ }^{\circ} \mathrm{C}$. Iz ovoga možemo zaključiti da su se tokom PEO procesa formirale odgovarajuće bronze tipa $\mathrm{ReO}_{3}$.

Ključne reči: Plazma elektrolitička oksidacija (PEO), ventilni metali, mikro pražnjenja, heteropoli kiseline, bronze.

Naučna oblast: Primenjena fizika

UDK broj: 53.086:533.9...15 (043.3) 


\section{Plasma electrolytic oxidation of valve metals}

This doctoral dissertation is focused on investigation of a relatively new, highvoltage anodization process, called Plasma Electrolytic Oxidation (PEO) on valve metals (such as $\mathrm{Al}, \mathrm{Mg}$, $\mathrm{Ti}$ and $\mathrm{Ta}$ ) and their oxide coatings obtained in tungsten containing heteropoly acids.

Very useful data concerning temperature, dimensional distribution of the microdischarges, their spatial density, and electron density were obtained using optical emission spectroscopy and real time imaging of PEO events. It is shown that the size of microdischarges becomes larger while their number decreases with increased time of PEO. Spatial density of microdischarges is the highest in the early stage of the PEO process and then slowly decreases. The percentage of oxide coatings' area simultaneously covered by active discharge sites decreases slowly with extended PEO time.

All atomic and ionic lines detected in optical emission spectra originate either from electrolyte or from the metal substrate. During the PEO process on magnesium, wide transition band was also recorded corresponding to the $\mathrm{v}^{\prime}-\mathrm{v}^{\prime \prime}=0$ band sequence of the $\mathrm{B}^{1} \Sigma^{+}-\mathrm{X}^{1} \Sigma^{+}$emission transition of MgO. During the PEO process on aluminum, visible band of $\mathrm{B}^{2} \Sigma^{+}-\mathrm{X}^{2} \Sigma^{+}$emission of $\mathrm{AlO}$ system was also detected. By applying spectroscopic, quantum-chemical and thermodynamical methods to analyze spectra in the range of those bands it was possible to determine the temperature of the microdischarges. In the case of PEO process on magnesium, calculated temperatures are about $11000 \mathrm{~K} \pm 2000 \mathrm{~K}$, while analysis of $\mathrm{OH}$ bands in the same sysstem yields sligtly lower value of $3500 \mathrm{~K} \pm 500 \mathrm{~K}$. Analysis of $\mathrm{AlO}$ band system gave temperature of 8000 $\mathrm{K} \pm 2000 \mathrm{~K}$.

The analysis of hydrogen Balmer $\mathrm{H}_{\beta}$ line shape in the case of PEO of tantalum and titanium, indicates the presence of two types of discharges during PEO process and the electron number densities of $\mathrm{Ne} \approx 0.8 \times 10^{15} \mathrm{~cm}^{-3}$ and $\mathrm{Ne} \approx 2.1 \times 10^{16} \mathrm{~cm}^{-3}$ are determined. These two electronic concentrations are similar to those obtained during the PEO process on aluminum. 
Morphology, chemical, and phase composition of oxide coatings on aluminum, titanium and tantalum are also investigated. The main goal was to find new, commercially acceptable, way of producing bronzes on surfaces of valve metals. Bronzes of heteropoly acids have very good catalytic and optical characteristics and as such can be used in many fields, such as catalysis, aerospace technology, and microelectronics. Characterization of oxide films produced by plasma electrolytic oxidation of valve metals was done utilizing scanning electron microscopy (SEM) equipped with energy dispersive spectroscopy (EDS), atomic force miscroscopy (AFM), and Raman spectroscopy. The crystallinity of the samples was analyzed using X-ray Diffraction (XRD).

The oxide coatings' morphology is strongly dependent on PEO time. Oxide coatings obtained in all systems under consideration show similar microstructure with two distinct regions: thin, compact inner layer adjacent to metal substrate and porous outer layer. The content of $\mathrm{W}$ is higher in porous outer layer while content of metal is higher in the inner layer. Oxide coatings are partly crystallized and mainly composed of metal oxides.

Raman spectra of oxide coatings on aluminum, titanium and tantalum are very similar to the referenceRraman spectrum of silicate tungsten bronze obtained by the thermal treatment of crystalline 12-tungstosilicic acid at $550{ }^{\circ} \mathrm{C}$, suggesting that obtained bronzes are of $\mathrm{ReO}_{3}$ type.

Keywords: Plasma electrolytic oxidation (PEO), valve metals, microdischarges, heteropoly acids, bronzes.

Scientific area: Applied physics

UDK number: 53.086:533.9...15 (043.3) 


\section{SADRŽAJ}

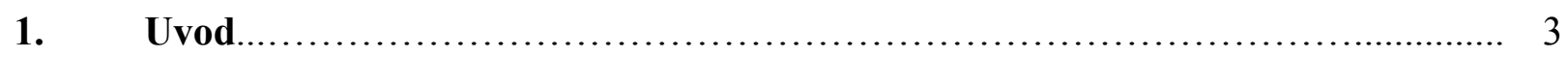

2. Plazma elektrolitička oksidacija (PEO) - pregled dosadašnjih rezultata............. 6

2.1. Mehanizam PEO procesa ....................................................... 6

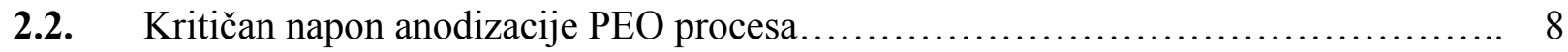

2.3. Nastanak i razvoj mikro pražnjenja u toku PEO procesa $\ldots \ldots \ldots \ldots \ldots \ldots \ldots \ldots \ldots \ldots . \quad 10$

2.4. Hemijske reakcije u plazmi u toku PEO procesa.................................................... 11

2.5. Osobine slojeva dobijenih PEO procesom .......................................................... 13

2.6. Osobine mikro pražnjenja u toku PEO procesa ................................................... 17

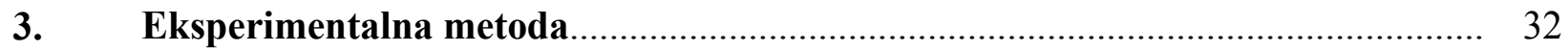

3.1. Ćelija za anodizaciju sa sistemom za termostatiranje elektrolita ............................ 32

3.2. Spektralna karakterizacija PEO procesa .............................................................. 33

3.3. Karakterizacija mikro pražnjenja u realnom vremenu......................................... 34

3.4. Karakterizacija oksidnih površina dobijene PEO procesom..................................... 34

4. Plazma eletktrolitička oksdacija aluminijuma............................................. 35

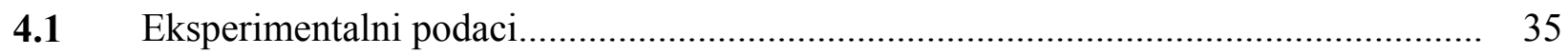

4.2 Optička karakterizacija i analiza PEO procesa na aluminijumu 35

u realnom vremenu.

4.2.1 Zavisnost napona i intenziteta luminescencije od vremena anodizacije..................... 36

4.2.2 Dinamika i distribucija mikro pražnjenja u toku PEO procesa.................................. 37

4.2.3 Spektralna karakterizacija PEO procesa........................................................... 39

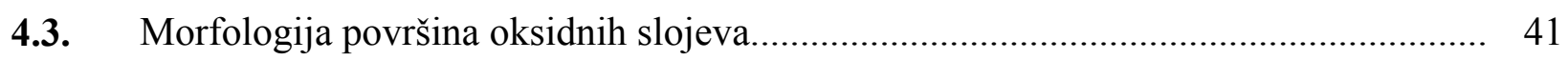

4.4. Hemijski i fazni sastav oksidnih površina....................................................... 42

5. Plazma elektrolitička oksidacija titanijuma .................................................. 47

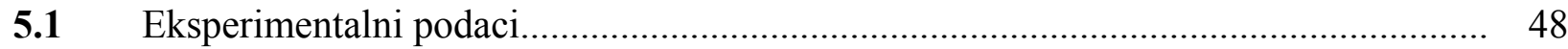


5.2 Optička karakterizacija i analiza PEO procesa na titanijumu

$\mathrm{u}$ realnom vremenu

5.2.1 Zavisnost napona i intenziteta luminescencije od vremena anodizacije.

5.2.2. Dinamika i distribucija mikro pražnjenja u toku PEO procesa...

5.2.3. Spektralna karakterizacija PEO procesa.

5.3. Morfologija površina oksidnih slojeva.

5.4. Hemijski i fazni sastav oksidnih slojeva......................................................... 54

6. Plazma elektrolitička oksidacija tantala ...................................................... 60

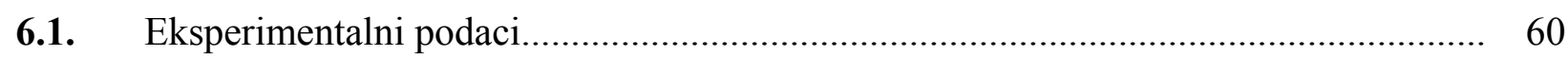

6.2. Optička karakterizacija i analiza PEO procesa na tantalu 61

u realnom vremenu.

6.2.1. Zavisnost napona $\mathrm{i}$ intenziteta luminescencije od vremena anodizacije.

6.2.2. Dinamika i distribucija mikro pražnjenja u toku PEO procesa.................... 60

6.2.3. Spektralna karakterizacija PEO procesa............................................................. 64

6.3. Morfologija površina oksidnih slojeva............................................................ 66

6.4. Hemijski i fazni sastav oksidnih slojeva............................................................ 68

7. Plazma elektrolitička oksidacija magnezijuma AZ31 ..................................... 73

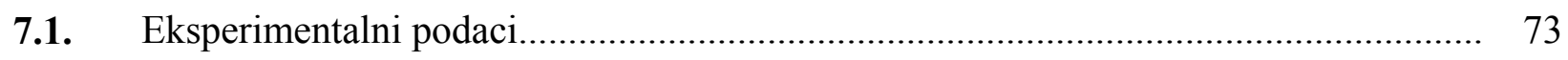

7.2. Optička karakterizacija i analiza PEO procesa na magnezijumu AZ31 74 $\mathrm{u}$ realnom vremenu.

7.2.1. Zavisnost napona $\mathrm{i}$ intenziteta luminescencije od vremena anodizacije.................... 74

7.2.2. Dinamika i distribucija mikro pražnjenja u toku PEO procesa................................. 75

7.2.3. Spektralna karakterizacija PEO procesa.......................................................... 77

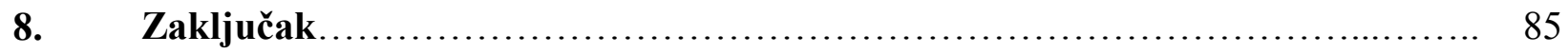

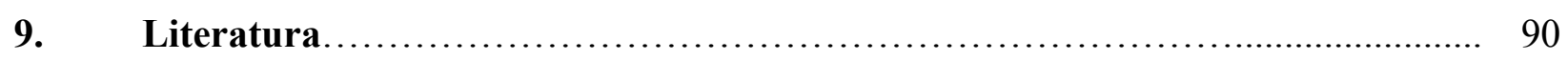




\section{UVOD}

Ubrzani tehnološki i industrijski razvoj koji prati kraj 20. i početak 21. veka, uslovio je ne samo potrebu za laganim, čvstim i otpornim materijalima na habanje i koroziju, već i potrebu za jednostavnijim, bržim i komercijalno povoljnijim tehnologijama za njihovu proizvodnju i zaštititu. Grupa elektrohemijskih procesa koji se u poslednje vreme koriste za dobijanje relativno debelih (do $500 \mu \mathrm{m}$ ), čvrstih (4 GPa do $23 \mathrm{GPa}$ ) i kompaktnih oksidnih slojeva na: magnezijumu, aluminijumu, titanijumu, cirkonijumu i ostalim ventilnim metalima i njihovim legurama, poznata je pod nazivom Plazma Elektrolitička Oksidacija (Plasma Electrolytic Oxidation - PEO) [1-5].

$\mathrm{Na}$ samom početku razvoja tehnologije PEO, postojalo je blago neslaganje u istraživačkim grupama oko naziva procesa pa se tako u radovima mogu pronaći termini: oksidacija u prisusutvu mikro pražnjenja (Microarc Oxidation, MAO) [6], anodna depozicija u prisustvu varničnih pražnjenja (Anodic Spark Deposition, ASD) [7-9] i slično. Sam termin Plazma Elektrolitička Oksidacija (PEO), pokazao se kao najpogodiniji i poslednjih godina zamenio je ostale.

Efekat PEO su pre 50-ak godina najpre zapazili naučnici iz bivšeg Sovjetskog Saveza i na temelju istraživanja za potrebe vojne industrije razvili su čitavu tehnologiju. Postoje nepotvrđeni podaci da su novi PEO materijali najpre korišćeni za izradu delova podmornica u bivšem Sovjetskom Savezu. U trci za razvoj PEO tehnologije sedamdesetih godina dvadesetog veka, uviđajući velike povoljnosti, ruskim naučnicima se pridružuju i naučnici iz Sjedinjenih Američkih Država i baza eksperimentalnih podataka o novim tretmanima polako, ali sigurno raste. Uporedo sa već patentiranim procesima baziranim na PEO efektu u SAD-u [10,11], Evropa i Izrael razvijaju svoje sopstvene verzije tehnologije, KEPLA-COAT i ALMAG-AL. Kasnije im se pridužuju i Kina, Japan i Australija.

Danas PEO tehnologije predstavljaju jednu od najrazvijenijih grana inžinjerstva površina. Posebno su značajne primene na legurama aluminijuma, magnezijuma i titanijuma. Neke od najpoznatijih svetskih kompanija su proteklih desetak godina preuzele dostignuća PEO istraživanja i danas pružaju usluge komercijalnih PEO tretmana. Jedna od najpoznatijih je Keronit Ltd iz Velike Britanije. 
Istraživačke grupe sa Univerziteta Cambridge i Sheffield smatraju se pionirima $u$ prikupljanju informacija o PEO procesima fokusiranim na karakterizaciju i testiranje oksidnih slojeva upravo na aluminijumu i titanijumu za koje postoji i najveći interes za primenu. Postoji i nekoliko komercijanih procesa kao što su Magoxid-Coat [12] i Tagnite [13] dostupnih u severnoj Americi a tiču se PEO procesa na magnezijumu.

Neke od najočiglednijih prednosti PEO tehnologije su:

- PEO je ekološki čista;

- Tehnologiju PEO je moguće primeniti na velikom broju metala i njihovih legura i na onima koje je ponekad teško anodizovati običnim postupkom;

- Ne zahteva velika finansijska ulaganja i ima visok odnos uloženog-dobijenog;

- Slojevi dobijeni na ovaj način su: uniformni, čvrsti, debeli, otporni na toplotne i hemijske tretmane i koroziju;

- PEO slojevi su delimično ili čak u potpunosti kristalizovani;

- Nije neophodan predtretman uzoraka metala.

Uz mnogobrojne prednosti, tehnologija PEO oksidacije ima i nedostatake. Pre svega, za postizanje visokih vrednosti napona koji prati PEO proces zahteva se upotreba nešto skupljih izvora, kao i stroga kontrola temperature elektrolita.

Proces PEO se sastoji od anodizacije metala u odgovarajućem elektrolitu uz primenu različitih potencijala izmedju elektroda i pojavu jakog električnog pražnjenja u blizini, na samoj površini ali i u samoj površini uzorka. Proces anodizacije se odvija do postizanja kritičnog napona i pojave svetlosnih efekta na površini metala [14], takozvanih mikro pražnjenja, u kojima se lokalno razvijaju izuzetno visoke temperature. Za razliku od obične anodizacije, PEO proces zahteva upotrebu jakih izvora za postizanje visokih vrednosti napona koje se uglavnom kreću u rasponu od $150 \mathrm{~V}$ do $1000 \mathrm{~V}$, bilo da se radi u direktnom ili naizmeničnom režimu. Vrednost kritičnog napona zavisi od materijala elektroda i vrste elektrolita. Na ovaj način nastaju oksidni slojevi željenih osobina: odlične termičke i hemijske otpornosti, otpornosti na koroziju, kompaktni su i čvrsti.

Značajnu ulogu u sastavu i osobinama PEO slojeva igra vrsta i koncentracija elektrolita. Grupu elektrolita koji se danas najčešće koriste u PEO procesima čine vodeni 
rastvori: $\mathrm{NaOH}$ [15], $\mathrm{Na}_{2} \mathrm{SiO}_{3}$ [16], $\mathrm{Na}_{3} \mathrm{PO}_{4}$ [17], $\mathrm{Na}_{2} \mathrm{Al}_{2} \mathrm{O}_{4}$ [18], $\mathrm{Na}_{2} \mathrm{WO}_{4} \cdot 2 \mathrm{H}_{2} \mathrm{O}$ [19] i pojedina heteropoli jedinjenja. Sa stanovišta odličnih katalitičkih, provodnih i poluprovodničkih osobina [20-23] posebno je zanimljiva poslednja grupa elektrolita, heteropoli kiseline i njihove soli koje sadrže volfram. Heteropoli kiseline smatraju se odličnim kandidatima u proizvodnji gorivnih ćelija i baterija [24-27] i kao materijali koji se mogu transformisati $\mathrm{u}$ nanoblokove [28]. Jedna od najpoznatijih i najupotrebljavanijih heteropoli kiselina je volframsilicijumska heteropoli kiselina (WSiA), molekulske formule $\mathrm{H}_{4} \mathrm{SiW}_{12} \mathrm{O}_{40}$. Ova kiselina, čiji anjon ima tipičnu Keggin-ovu strukturu [24,29,30], ima niskotemperaturni fazni prelaz u bronzu na približno $535{ }^{\circ} \mathrm{C}$ [25] i može se očekivati da posluži kao prekursor u proizvodnji odgovarajućih bronzi u toku PEO.

Merenja vršena na Katedri za Primenjenu fiziku i metrologiju Fizičkog fakulteta $u$ Beogradu imala su za cilj da istraže PEO fenomen na ventilnim metalima (aluminijum, titanijum, tantal i magnezijum) prvenstveno primenom metoda optičke emisione spektroskopije i analizom procesa u realnom vremenu. Ovim istraživanjima je omogućeno određivanje temperature plazma pražnjenja, elektronske gustine plazme, dimenzionalne distribucije i aktivne površine mikro pražnjenja.

Posebna pažnja je bila fokusirana na istraživanju morfologije, hemijskog i faznog sastava oksidnih površina dobijenih PEO procesom na aluminijumu, tantalu i titanijumu u elektrolitima koji sadrže volfram, pre svega u WSiA, sa idejom da se ispita dobijanje bronzi na nov i komercijalno povoljan način. Karakterizacija dobijenih površina je vršena fizičko hemijskim metodama: AFM mikroskopijom, SEM-EDS mikroskopijom, rentgeno strukturnom analizom $X$-zracima i Raman spektroskopijom.

Rad na ovoj doktorskoj disertaciji je delom finansiran od Ministarstva za nauku Republike Srbije u okviru projekata "Ugljenične i neorganske nanotube" i "Grafitne i neorganske nanostrukture niske dimenzionalnosti““.

Kao neposredni rezultat rada na ovoj disertaciji, u proteklih nekoliko godina je objavljen značajan broj radova u vrhunskim međunarodnim časopisima iz oblasti primenjene fizike, nauke o materijalima i elektrohemije. Dokaz velikog interesovanja za problematiku obrađenu u ovoj disertaciji je i veliki broj citata od strane vodećih istraživačkih grupa iz ove oblasti, koji predstavljaju dobar osnov za budući rad. U planu su istraživanja kojima bi se detaljno ispitale fotokatalitičke $\mathrm{i}$ antikorozivne osobine materijala dobijenih primenom PEO tehnike, što bi moglo biti od izuzetnog značaja za brojne primene. 


\section{PLAZMA ELEKTROLITIČKA OKSIDACIJA (PEO) - PREGLED DOSADAŠNJIH REZULTATA}

\subsection{Mehanizam PEO procesa}

Obična anodizacija metala je postupak prevlačenja površine metala zaštitnim oksidnim slojem u pogodnom elektrolitu primenom odgovarajućeg napona. Svi elektrodni procesi koji se dešavaju u toku obične anodizacije se uglavnom posmatraju u krajnje pojednostavljenom, dvofaznom sistemu koji čine elektroda-elektrolit i metal-elektrolit, ili pak pomešani oksid-elektrolit sistem sa graničnom površi koja je u stvari dvojni električni sloj. Konkurentni procesi oslobađanja gasnih molekula se obično u ovakvom sistemu zanemaruju ili uzimaju u obzir preko specijalnih korekcionih faktora (npr. doprinos struje ili koeficijent zaštite elektrode). Ovakvo pojednostavljenje nije uvek opravdano ako se uzme u obzir da eksperimentalni rezultati zavise i od procesa koji se dešavaju upravo u gasnoj fazi. PEO procesi se u stvari dešavaju u kompleksnijem, četvorofaznom sistemu koji čine: metaldielektrični sloj-gas-elektrolit [14,31,32].

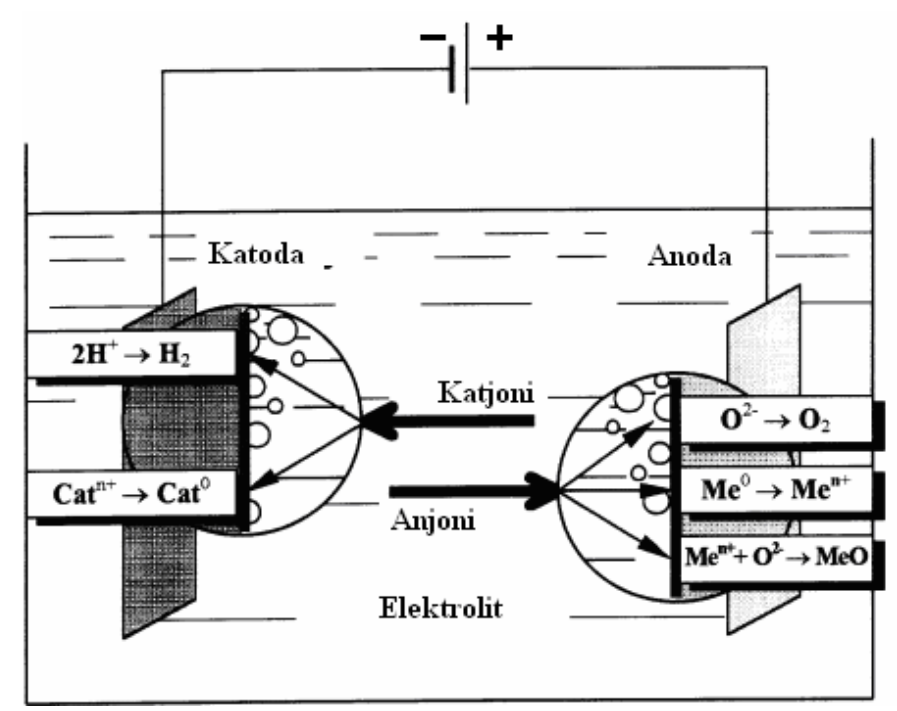

Slika 2.1. Elektrodni procesi u toku anodizacije metala u vodenim rastvorima [14]

Mehanizmom PEO procesa na aluminijumu bavile su se uglavnom istraživačke grupe na čelu sa Yerokhin-om [14,31,32] i Hussein-om [33,34]. Jedna od najopsežnijih studija je 
upravo predstavljena od strane Yerokhin-a i saradnika [14]. Oni su sproveli opsežno istraživanje mehanizma PEO procesa na aluminijumu uzimajući u obzir da je svaki PEO proces praćen oslobađanjem gasnih molekula kiseonika i rastom oksidacionog sloja na anodimetalu (SI. 2.1). Da li će doći do rastvaranja metala u elektrolitu ili rasta oksidnog sloja zavisi od hemijske aktivnosti elektrolita u odnosu na izabrani metal.

Na samom početku PEO proces podseća na običnu anodizaciju. Napon raste linearno i srazmerno debljini nastalog oksidnog sloja, sve dok se ne dostigne vrednost kritičnog napona. Kritičan napon zavisi od: vrste elektrolita, metala i uslova anodizacije i obično se kreće od nekoliko desetina volti do nekoliko stotina volti [33]. Dostizanje kritičnog napona je praćeno pojavom varničnih pražnjenja-sparkinga, odnosno mikro pražnjenja, na površini uzorka. Gustine struja u toku procesa dostižu vrednosti i do nekoliko desetina $\mathrm{A} / \mathrm{dm}^{2}$.

Strujno naponska karakteristika PEO procesa na aluminijumu u neposrednoj blizini anode (Sl. 2.2 tip-a) i dielektričnom filmu na površini elektrode (SI. 2.2 tip-b), pokazuje da se u oblasti niskih napona oba sistema ponašaju u skladu sa Omovim zakonom i rast napona je direktno proporcionalan porastu gustine struje $\mathbf{0}-\boldsymbol{U}_{\mathbf{1}} \mathrm{u}$ sistemu a i $\mathbf{0}-\boldsymbol{U}_{\mathbf{4}} \mathrm{u}$ sistemu b.

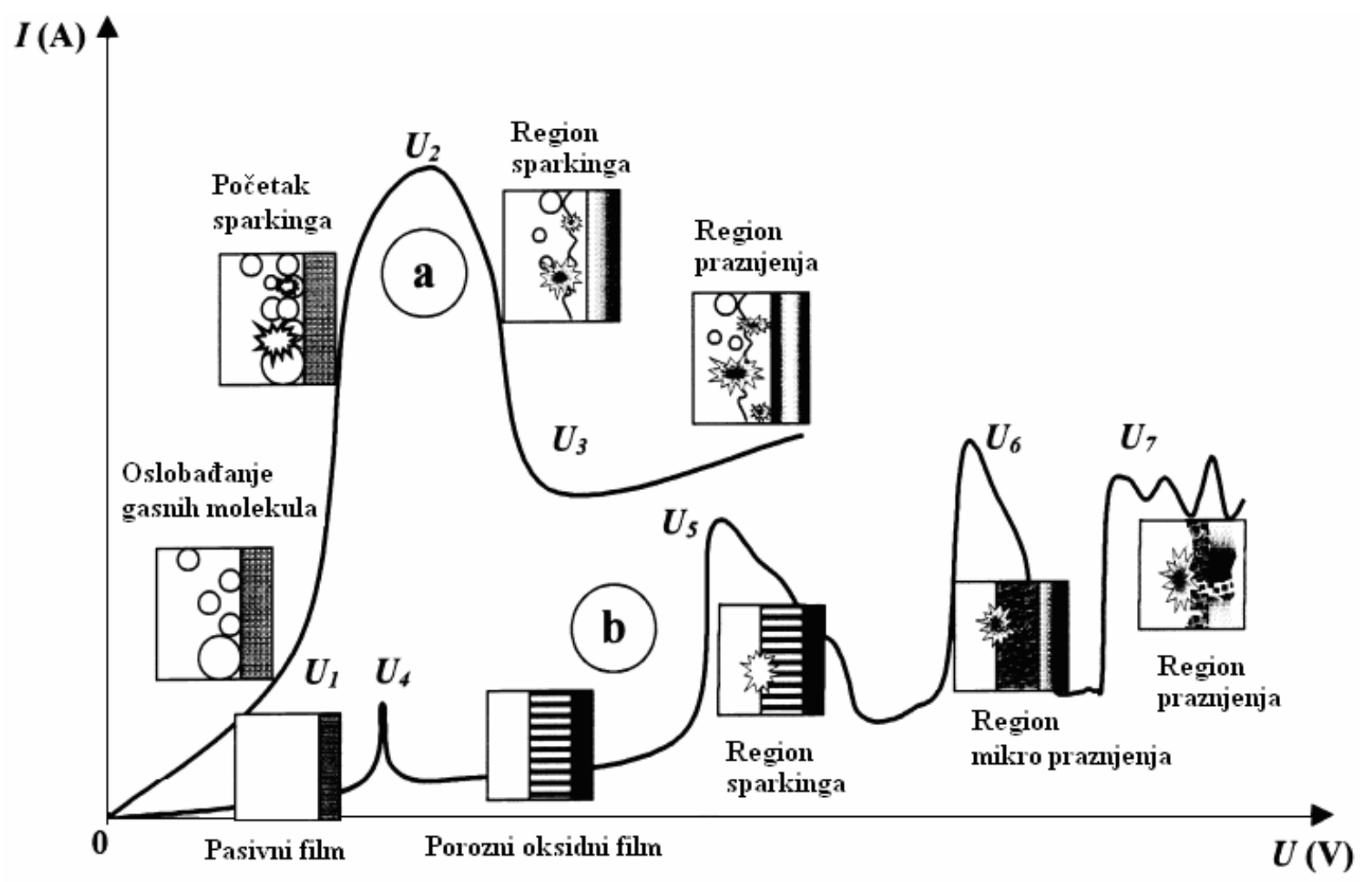

Slika 2.2. Strujno naponska karakteristika PEO procesa:

(a) u oblasti u blizini površine elektrode; (b) u dielektričnom filmu, na površini elektrode [14]. 
U slučaju sistema metal-elektrolit, u oblasti napona $\boldsymbol{U}_{1}-\boldsymbol{U}_{2}$, porast potencijala dovodi do oscilacija u jačini struje i uvek je praćen luminescencijom. Rast gustine struje je ograničen pojavom sloja gasnih molekula $\left(\mathrm{H}_{2} \mathrm{i}_{2}\right)$ i hemijskim reakcijama u njima u blizini površine elektrode. U oblastima u kojima elektroda ostaje u direktnom kontaktu sa elektrolitom, porast gustine struje se nastavlja i dovodi do lokalnog pregrejavanja elektrolita u kontaktu sa površinom sloja. Kada se postigne napon anodizacije $\boldsymbol{U}_{2}$, celokupna površina elektrode je prekrivena slojem izuzetno pregrejanog gasa niske propustljivosti. Jačina električnog polja u ovoj oblasti dostiže izuzetno visoke vrednosti, između $10^{6} \mathrm{~V} / \mathrm{m}$ i $10^{8} \mathrm{~V} / \mathrm{m}$, što je više nego dovoljno da u njemu otpočne proces jonizacije. Sam proces jonizacije najpre se manifestuje u vidu brzih mikro pražnjenja u gasnim mehurićima, a potom se uniformno proširuje po čitavoj površini uzorka. Hidrodimička stabilnost gasnog regiona u oblasti $\boldsymbol{U}_{\mathbf{2}}-\boldsymbol{U}_{3}$, uslovljava pad gustine struje i sada učestalija mikro pražnjenja su praćena i zvučnim efektima niske frekvencije.

Ponašanje sistema b je mnogo komplikovanje kada se posmatra zavisnost promene gustine struje sa naponom. U prvom koraku već formirani pasivni sloj oksida se rastvara sve dok se ne dostigne vrednost napona $\boldsymbol{U}_{\mathbf{4}}$ (jednak korozivnom potencijalu materijala, u ovom slučaju aluminijuma). U narednom koraku, u oblasti potencijala $\boldsymbol{U}_{4}-\boldsymbol{U}_{5}$, rast poroznog oksidnog sloja je praćen novim padom napona. Postizanjem potencijala $\boldsymbol{U}_{5}$, električno polje $\mathrm{u}$ oksidnom sloju dostiže kritičnu vrednost iznad koje dolazi do električnog proboja $[35,36]$ i opažaju se brža mikro pražnjenja. Pri naponu $\boldsymbol{U}_{\mathbf{6}}$, termalna jonizacija daje svoj doprinos mehanizmu sudarne jonizacije i sama mikro pražnjenja postaju veća ali se čitav proces sada usporava i broj mikro pražnjenja smanjuje. U oblasti potencijala $\boldsymbol{U}_{\mathbf{6}}-\boldsymbol{U}_{7}$, termalna jonizacija je delimično zaustavljena nagomilanim negativnim naelektrisanjem u oksidnom sloju dovodeći do njegovog kratkog dielektričnog raspada. Ovaj efekat je, prema Yerokhinu, praćen pojavom slabih i kratkoživećih mikro pražnjenja [14]. Zahvaljujući upravo takvim mikro pražnjenjima, na potencijalima koji su iznad $\boldsymbol{U}_{7}$, u oksidnom sloju se tokom njegovog rasta, ugrađuju elementi iz elektrolita, ali zbog postojanja negativnog naelektrisanja u oksidnom sloju, u ovoj oblasti napona može doći do termalnog pucanja sloja [37].

\subsection{Kritičan napon anodizacije PEO procesa}

Teorija jonizacije elektronskim udarima pokazuje se kao dovoljno dobra za objašnjenje dobijenih eksperimentalnih vrednosti napona na samom početku anodizacije, $u$ 
oblasti $\boldsymbol{U}_{\mathbf{1}}-\boldsymbol{U}_{2}$ na $\mathbf{S}$. 2.2 , uz pretpostavku da se proces jonizacije dešava $\mathrm{i} u$ vazdušnom balonu, neposredno uz površinu metala.

U slabo jonizovanom gasu (mali broj naelektrisanja u gasnom balonu), elektroni se $u$ toku svog haotičnog kretanja sudaraju uglavnom sa neutralnim atomima. Svaki elektron za vreme između dva sudara se ubrzava usled postojanja električnog polja. Pod određenim uslovima, za određenu vrstu i pritisak gasa i dovoljnu jačinu električnog polja, elektroni mogu da između dva sudara steknu dovoljnu energiju za vršenje sekundarnih jonizacija. U ovakvim uslovima, broj elektrona će se stalno povećavati, što će dovesti do formiranja elektronske lavine. Za opisivanje ovog dela procesa Townsend je uveo koeficijent jonizacije elektronskim udarom $\alpha$, koji predstavlja broj jonskih parova koje stvara elektron po jedinici dužine puta. On se takodje naziva prvim Townsend-ovim koeficijentom, a proces jonizacije elektronskim udarom $\alpha$-procesom. Koristeći upravo pomenuti koeficijent, jačina električnog polja se može približno izračunati iz jednačine (2.1) [38]:

$$
E_{e l}=(b \cdot p) \ln \left(\frac{\alpha}{a \cdot p}\right)
$$

gde su: $p$ (Pa) pritisak gasa, $b$ i $a$ eksperimentalne konstante. Koristeći jednačinu (2.1), Van [39] i Nie [40] su za konkretan slučaj anodizacije aluminijuma izračunali približan kritični napon od $40 \mathrm{~V}$, dok se eksperimentalno dobijene vrednosti kreću u rasponu od $40 \mathrm{~V}$ do $80 \mathrm{~V}$ $[39,40]$.

U oblasti napona $\boldsymbol{U}_{2}-\boldsymbol{U}_{3}$ na Sl. 2.2, kada jačine električnog polja dostižu vrednosti izmedju $10^{6} \mathrm{~V} / \mathrm{m}$ i $10^{8} \mathrm{~V} / \mathrm{m}$, napon $\boldsymbol{U}_{2-3}$ se može proceniti poznajući kritičnu vrednost Džulove toplote, $W_{\mathrm{c}}$ koja prati prelaz iz gasnog mehura u oksidni sloj.

$$
j \cdot U_{(2-3)}=W_{c},
$$

gde je $j$-gustina struje. Uz pretpostavku da je $W_{\mathrm{c}}$ vrednost bliska kritičnoj toploti ključanja vode $\left(\sim 8 \cdot 10^{5} \mathrm{~W} / \mathrm{m}^{2}\right)[41]$ i da gustina struje varira u opsegu od $4 \mathrm{kA} / \mathrm{m}^{2}$ do $10 \mathrm{kA} / \mathrm{m}^{2}$, lako se procenjuje da se vrednosti napona $\boldsymbol{U}_{2-3}$ kreću u rasponu od $80 \mathrm{~V}$ do $200 \mathrm{~V}$, što se odlično slaže sa eksperimentalnim rezultatima [40].

Napon proboja $U_{5}$ se računa uz pomoć eksperimentalno potvrđene i delimično modifikovane Gunterschultze-ove jednačine [34,35,37]: 


$$
U_{5}=\frac{E}{\alpha} \cdot \ln \left(\frac{z}{a \eta C^{b}}\right),
$$

gde su $a$ i $b$ konstante, $C$ je koncentracija elektrolita, $z$ elementarno naelektrisanje i $\eta$ deo elektronske struje u odnosu na ukupnu struju koja prolazi kroz sistem.

Vrednosti napona $\boldsymbol{U}_{6}$ i $\boldsymbol{U}_{7}$ se računaju na osnovu teorije termalne jonizacije u čvrstom stanju [38], uzimajući u obzir efektivnu debljinu (2h za $\boldsymbol{U}_{6}$ ) ili ukupnu debljinu (2h za $\boldsymbol{U}_{7}$ ) dielektričnog sloja. U tom slučaju se kritična jačina električnog polja može proceniti jednačinom [38] (2.4):

$$
E_{c 2}=\frac{\beta_{0} e^{\left(\beta_{o} t h \beta_{o}\right) / c} \sqrt{\frac{2 k}{a \gamma_{a 0}}}}{h c h \beta_{0}}
$$

gde su $\beta_{o}$ i $C$ tabelarni parametri, $k$ je toplotni koeficijent provodljivosti, $a$ je koeficijent iz jednačine $\gamma_{a}=\gamma_{a 0} e^{a\left(T-T_{o}\right)}, \quad \gamma_{a 0}$ električna provodljivost dielektrika na temperaturi $T_{0}$. Jednačina (2.4) se dobro slaže sa eksperimentalnim podacima ali samo za PEO slojeve debljine manje od $30 \mu \mathrm{m}[43]$.

\subsection{Nastanak i razvoj mikro pražnjenja u toku PEO procesa}

Postojeći modeli koji nastoje da objasne poreklo mikro pražnjenja u toku PEO procesa mogu se grubo podeliti u dve grupe. Prema prvom modelu [42,44-47], mikro pražnjenja nastaju kao rezultat dielektričnog proboja u oksidnom filmu, u jakom električnom polju, na mestima strukturnih defekata i nečistoća (SI. 2.3-a). Drugi predložen model [48-52] tretira pojavu mikro pražnjenja u gasnom balonu, u mikropori oksidnog filma (Sl. 2.3-b). Smatra se da je formiranje gasnog balona u mikropori i pojava mikro pražnjenja posledica dielektričnog proboja oksidnog sloja na dnu kanala. Pored ova dva modela, Hickling i Ingram [53] su predložili jedan alternativni model (Sl. 2.3-c). U njihovim eksperimentima, svetlosni efekti se javljaju na površini elektrolita, a na površini oksida se formira tanak, vazdušni štit. Oni smatraju da se sva pražnjenja dešavaju upravo u tom tankom, vazdušnom balonu uz samu površinu uzorka. 


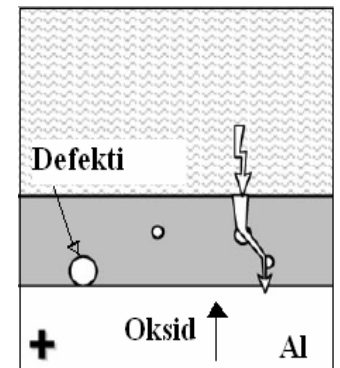

a)

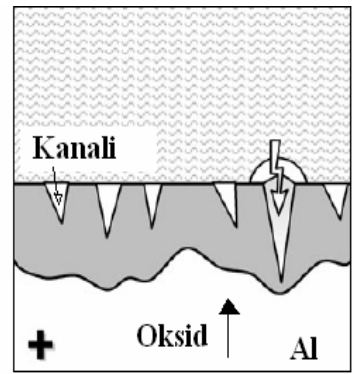

b)

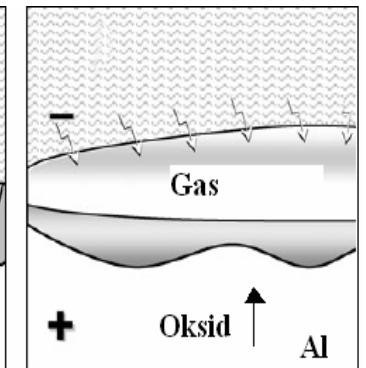

c)

Slika 2.3. Šematski prikaz modela nastanka mikro pražnjenja u toku PEO procesa [32]

Prema Yerokhin-u [32], elektronska emisija sa granice elektrolit-oksid u gasnu fazu, verovatniji je uzrok pojave mikro pražnjenja od dielektričnog proboja oksidnog sloja. Ipak, slobodni elektroni se mogu pojaviti na granici oksid-elektrolit u jakom elektičnom polju bez obzira da li postoji ili ne gasna faza u blizini. U tom slučaju, slobodni elektroni odmah stupaju u reakciju sa vodenim molekulima, formirajući gasne produkte $\left(\mathrm{H}_{2}\right.$ i $\left.\mathrm{O}_{2}\right)$ i stvarajući uslove za stvaranje i održavanje mikro pražnjenja.

\subsection{Hemijske reakcije u plazmi u toku PEO procesa}

Činjenicom da se u toku PEO lokalno mogu razviti vrlo visoke temperature za kratko vreme, može se objasniti formiranje specifičnih struktura na površini (metastabilnih visoko temperaturnih faza, neravnotežnih čvrstih rastvora i slično). Sve ove faze su rezultat odgovarajućih hemijskih reakcija u plazmi. U zavisnosti od eksperimentalnih uslova, pomenute reakcije se mogu odigrati u gasnom balonu u blizini elektrode ili na njenoj samoj površini.

Sve hemijske reakcije se u toku PEO procesa vrše u dva koraka. U prvom, dolazi do sudarne ili termalne jonizacije i disocijacije hemijskih vrsta prisutnih u elektrolitu [54]. Zahvaljujući snažnom egzotermnom efektu, proces je brz i plazma u kanalima za pražnjenje dostiže vrlo visoke temperature za vrlo kratko vreme $\sim 10^{-6} \mathrm{~s}$. Električno polje prisutno u kanalima razdvaja naelektrisanja i pozitivni joni odlaze u elektrolit, a negativni joni učestvuju u hemijskim procesima na površini elektrode.

U narednom koraku PEO procesa, temperatura u kanalima za pražnjenje naglo pada (brzina hlađenja se kreće oko $10^{8} \mathrm{~K} / \mathrm{s}$ ) i na površini filma ostaju zarobljene: metastabilne faze, prezasićeni čvrsti rastvori i druge neravnotežne faze. Na ovaj način se mogu dobiti $\alpha$ i $\gamma$ 
faza $\mathrm{Al}_{2} \mathrm{O}_{3}$ [55], $\mathrm{MgO}$ [56], $\mathrm{TiO}_{2}$ (anatas $\mathrm{i}$ rutil) [57], $\alpha-\mathrm{SiO}_{2}$ [58], $\delta-\mathrm{Nb}_{2} \mathrm{O}_{5}$ [59, 60], $\mathrm{CdNb}_{2} \mathrm{O}_{6}$ [61], $\mathrm{Al}_{2} \mathrm{TiO}_{5}$ [57], $\mathrm{BaTiO}_{3}$ [57], $\mathrm{NaNbO}_{3}$ [59] itd.

Predložen model hemijskih reakcija koje se dešavaju u toku anodizacije aluminijuma u alkalnim elektrolitima sastoji se iz [62-64]:

1. Formiranja oksidnog sloja usled migracija $\mathrm{Al}^{3+}$ jona na granici metal-oksid $\mathrm{i}$ anjonskih vrsta formiranih na granici oksid-elektrolit $[63,64]$ (SI. 2.1).

$$
2 \mathrm{Al}+9 \mathrm{H}_{2} \mathrm{O} \rightarrow \mathrm{Al}_{2} \mathrm{O}_{3}+6 \mathrm{H}_{3} \mathrm{O}+6 \mathrm{e}^{--}
$$

2. Hemijskog rastvaranja aluminijum oksida nakon uklanjanja zaštitnog oksidnog sloja:

$$
\begin{aligned}
& \mathrm{Al}_{2} \mathrm{O}_{3}+2 \mathrm{OH} \rightarrow 2 \mathrm{AlO}_{2}^{-}+\mathrm{H}_{2}, \\
& 2 \mathrm{AlO}_{2}{ }^{-}+2 \mathrm{H}_{3} \mathrm{O}^{+}+(\mathrm{n}-3) \mathrm{H}_{2} \mathrm{O} \leftrightarrow \mathrm{Al}_{2} \mathrm{O}_{3} \cdot \mathrm{nH}_{2} \mathrm{O} .
\end{aligned}
$$

\section{Izbacivanja aluminijuma u elektrolit:}

$$
\mathrm{Al}_{\mathrm{ej}}+3 \mathrm{OH}^{-} \rightarrow \mathrm{Al}(\mathrm{OH})_{3}+3 \mathrm{e}^{-}
$$

U konkretnom slučaju PEO procesa na aluminijumu u volframskim elektrolitima [19] na granici metal-oksid se u prvom koraku aluminijum oksiduje:

$$
\begin{aligned}
& 2 \mathrm{Al}+3 \mathrm{O}_{\text {solid }}^{2-} \rightarrow \mathrm{Al}_{2} \mathrm{O}_{3}+6 \mathrm{e}^{-}, \\
& \mathrm{Al} \rightarrow \mathrm{Al}_{\text {solid }}^{3+}+3 \mathrm{e}^{-},
\end{aligned}
$$

a na granici oksid-elektrolit:

$$
2 \mathrm{Al}_{\text {solid }}^{3+}+9 \mathrm{H}_{2} \mathrm{O} \rightarrow \mathrm{Al}_{2} \mathrm{O}_{3}+6 \mathrm{H}_{3} \mathrm{O}^{+}
$$

Volfram se iz elektrolita ugrađuje u PEO sloj zahvaljujući reakcijama [65]:

$$
\begin{gathered}
2 \mathrm{Al}_{\text {solid }}^{3+}+\left[\mathrm{WO}_{4}^{2-}\right]_{\text {electolyte }}+6 \mathrm{H}_{2} \mathrm{O} \rightarrow \mathrm{WO}_{3}+\mathrm{Al}_{2} \mathrm{O}_{3}+4 \mathrm{H}_{3} \mathrm{O}^{+}, \\
{\left[\mathrm{WO}_{4}^{2-}\right]_{\text {electrolyte }}+2 \mathrm{H}_{3} \mathrm{O}^{+} \rightarrow \mathrm{WO}_{3}+3 \mathrm{H}_{2} \mathrm{O} .}
\end{gathered}
$$


Jako električno polje u kanalima za pražnjenje privlači negativne jone $\mathrm{WO}_{4}{ }^{2-}$ koji se potom oksiduju prema reakciji (2.14) [66]:

$$
2\left[\mathrm{WO}_{4}^{2-}\right]_{\text {electrolyte }}-4 \mathrm{e}^{-} \rightarrow 2 \mathrm{WO}_{3}+\mathrm{O}_{2} \uparrow
$$

Hemijske vrste $\mathrm{WO}_{3}$, u sudaru sa prisutnim elementarnim aluminijumom, se mogu dalje redukovati do elementarnog volfram prema reakciji (2.15) [66]:

$$
\mathrm{WO}_{3}+2 \mathrm{Al} \rightarrow \mathrm{Al}_{2} \mathrm{O}_{3}+\mathrm{W}
$$

\subsection{Osobine slojeva dobijenih PEO procesom}

Kao što je pomenuto u uvodnom delu, PEO slojevi pokazuju odličnu otpornost na habanje, koroziju i visoku tvrdoću, ali i poželjne električne i izolatorske osobine [1-4]. Sve ove osobine, osim što zavise od kombinacije metala i elektrolita, zavise od mnogih eksperimentalnih parametara, a najviše od dužine trajanja procesa [67-77].

Debljine PEO slojeva mogu dostići vrednosti i od nekoliko stotina $\mu \mathrm{m}$. Brzina rasta je uglavnom linearna [78-83] i kreće se od nekoliko stotina $\mu \mathrm{m}$ do svega nekoliko nm po minuti u zavisnosti od izbora elektrolita, metala i gustine struje.

Morfologija PEO površina pre svega zavisi od vremena anodizacije, vrste metala koji se anodizira i izbora elektrolita. U svim dosada publikovanim radovima, prikazane su PEO površine ispunjene kraterima i pukotima, kao posledica mikro pražnjenja u oksidnim slojevima, na i u blizini površine uzorka (SI. 2.4). Pore su uglavnom okružene materijalom u kraterskim strukturama izbačenim iz kanala za pražnjenje koji se u kontaktu sa elektrolitom naglo ohladio. Dimenzije svih struktura kreću se od nekoliko $\mu \mathrm{m}$ pa do nekoliko stotina nm. Sundararajan, Rama Krishna i Shen [78,84] su ispitivali kako se dijametar poprečnog preseka kratera menja sa dužinom PEO procesa na aluminijumu. Obe studije su zapazile gotovo linearan porast dijametra poprečnog preseka sa vremenom anodizacije. Eksperimentalni podaci Sunderarajan-a i Rama Krishna-a pokazuju da su poprečni preseci PEO struktura $1 \mathrm{~min}$ od početka procesa $\sim 1.4 \mu \mathrm{m}$, a da nakon $30 \mathrm{~min}$ ta vrednost iznosi gotovo $2.4 \mu \mathrm{m}$. Rezultati se odnose na 5 najvećih pora pronađenih na uzorku. Ovo je, može se reći, gornja granica kada su u pitanju dimenzije mikropora i kratera. Shen i saradnici su dobili nešto veći porast $\mathrm{u}$ dijametrima poprečnih preseka kratera za ista vremena anodizacije (sa $\sim 1 \mu \mathrm{m}$ nakon 
1 min PEO vremena na $\sim 9 \mu \mathrm{m}$ nakon $30 \mathrm{~min}$ ), ali nisu precizirali na koji način su vršili odabir reprezentativnih pora [84].

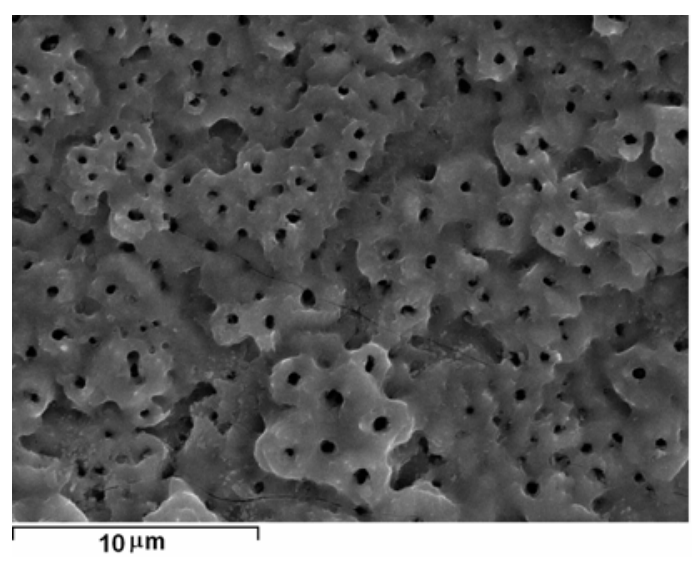

Slika 2.4. Tipična morfologija oksidne površine dobijene PEO procesom

Dok dimenzije pora i kratera rastu sa vremenom PEO, njihov broj, odnosno gustina, se smanjuje. Objašnjenje leži u samom mehanizmu PEO procesa. Kako debljina sloja raste, broj mesta gde je otpor struji mali (nečistoće i razne vrste nepravilnosti na površini metala) se smanjuje pa samim tim i broj mikro pražnjenja u blizini, na površini i u kanalima. Pošto gustina struje ostaje nepromenjena, a broj potencijalnih slabih mesta je smanjen, prolaz struje se lokalizuje upravo na tim mestima i mikro pražnjenja postaju dimenzionalno veća a samim tim i površine poprečnih preseka kratera i pukotina rastu.

Sundararajan i Rama Krishna su pratili i kako se sa PEO vremenom menja površinska gustina pora i kratera na aluminijumu. Prema njihovim rezultatima, gustina pora i kratera posle 1 min od početka PEO procesa iznosi $\sim 1.1 \cdot 10^{16} \mathrm{~m}^{-2}$, da bi nakon 30 min pala za dva reda veličine, na $\sim 5 \cdot 10^{14} \mathrm{~m}^{-2}$, dok su Curran i Clyne publikovali podatak od $\sim 1.4 \cdot 10^{10} \mathrm{~m}^{-2} \mathrm{za}$ PEO slojeve debljine $\sim 5 \mu \mathrm{m}$ (nastale nakon 5 min PEO vremena) $\mathrm{i} \sim 1 \cdot 10^{9} \mathrm{~m}^{-2}$ za slojeve debljine $40 \mu \mathrm{m}$ (100 $\mathrm{min})[78,85]$.

Pogodna metoda za procenu mikro tvrdoće PEO slojeva je nanoindentacija. Ova metoda se može koristiti samo ukoliko je moguće ostvariti da PEO sloj ne pukne izložen pritisku indentera. Mikro tvrdoća se proračunava iz odnosa dubine prodiranja dijamantske igle i upotrebljene sile pritiska. Curran and Clyne, u slučaju PEO slojeva na aluminjumu, prijavljuju vrednosti od $20 \mathrm{GPa}$ [85]. Nešto niže vrednosti su u slučaju PEO slojeva na magnezijumu dobili Arrabal i saradnici, počev od 2.0 GPa do 4.4 GPa [74]. Primećena je tendencija da je mikro tvrdoća PEO slojeva najveća u početnim fazama PEO procesa i da 
potom naglo opada. Slično ponašanje pokazuju i uzorci aluminijuma anodizirani u vodenom rastvoru $0.01 \mathrm{M} \mathrm{Na} \mathrm{WO}_{4} \cdot 2 \mathrm{H}_{2} \mathrm{O}$ [19]. Na Sl. 2.5. je dat izgled dela površine uzorka aluminijuma izložen testu nanoindentacije, dok je uticaj PEO vremena na mikro tvrdoću prikazan na SI. 2.6. Kao što se može i očekivati, visoke vrednosti mikro tvrdoće se vezuju za PEO slojeve koji nastaju u prvih 5 min procesa, dok je već nakon 10 min ta vrednost duplo niža. U završnim fazama PEO procesa na aluminijumu nastaju slojevi čija mikro tvrdoća ne prelazi vrednost oko $1 \mathrm{GPa}$. Poznajući kako se mikro tvrdoća menja sa PEO vremenom moguće je za konkretnu kombinaciju metala, elektrolita i eksperimentalnih uslova dobijati materijale željene mikro tvrdoće.

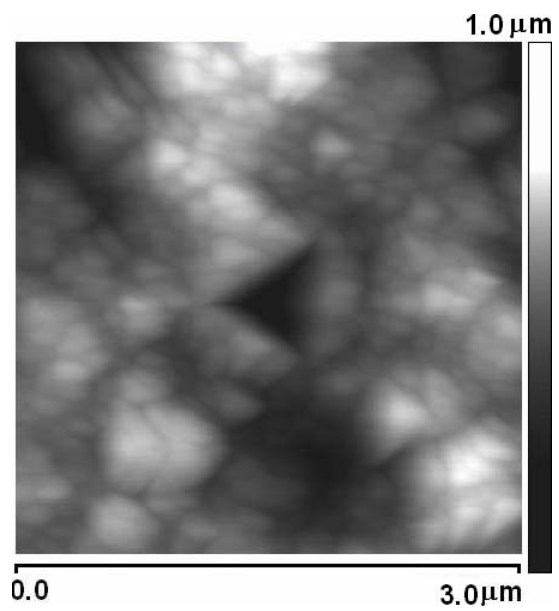

Slika 2.5. Izgled PEO površine nakon procesa nanoindentacije na sloju dobijenom PEO procesom na aluminijumu u $0.01 \mathrm{M} \mathrm{Na}_{2} \mathrm{WO}_{4} \cdot 2 \mathrm{H}_{2} \mathrm{O}[19]$.

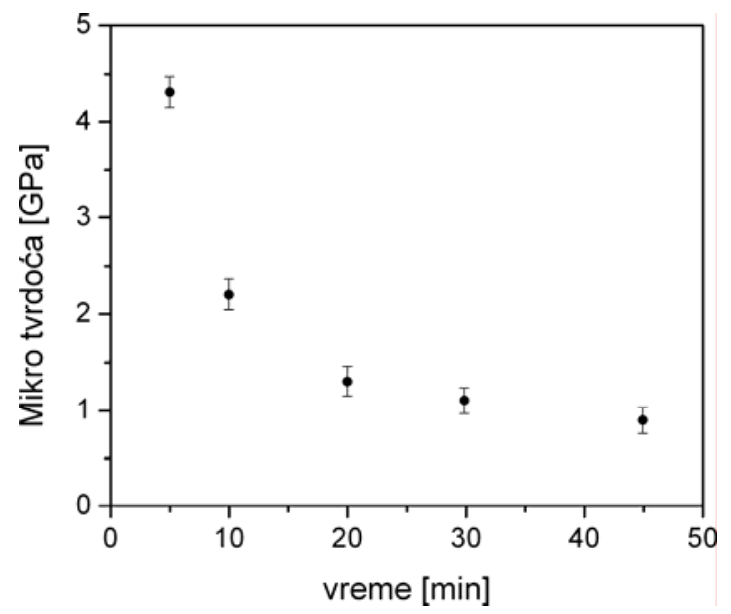

Slika 2.6. Uticaj vremena PEO procesa na mikro tvrdoću oksidnih površina na aluminjumu dobijenih u $0.01 \mathrm{M} \mathrm{Na}_{2} \mathrm{WO}_{4} \cdot 2 \mathrm{H}_{2} \mathrm{O}$ [19]. 
Rezultati snimanja poprečnih preseka PEO slojeva (SI. 2.7) ukazuju na postojanje dva morfološki različita regiona:

1. Kompaktni unutrašnji sloj, koji je izuzetno čvrst,

2. Porozni površinski sloj.

Ovakva morfološka razdvojenost sloja dobijenog PEO procesom na aluminijumu je dokumentovana u brojnim radovima [32,70,81,86,87]. Dvoslojne prevlake dobijene PEO tehnikom su detektovane i na magnezijumu [88, 89] i titanijumu [90].

Postoje i istaživačke grupe koje razlikuju i treći, tanak barijerni sloj (debeo svega nekoliko nm), neposredno uz samu površinu metala [3,5]. Pokazano je i da unutrašnji, barijerni sloj pruža zaštitu površine metala od korozije, dok srednji, kompaktni deo sloja pruža PEO materijalima visoku mikro tvrdoću.

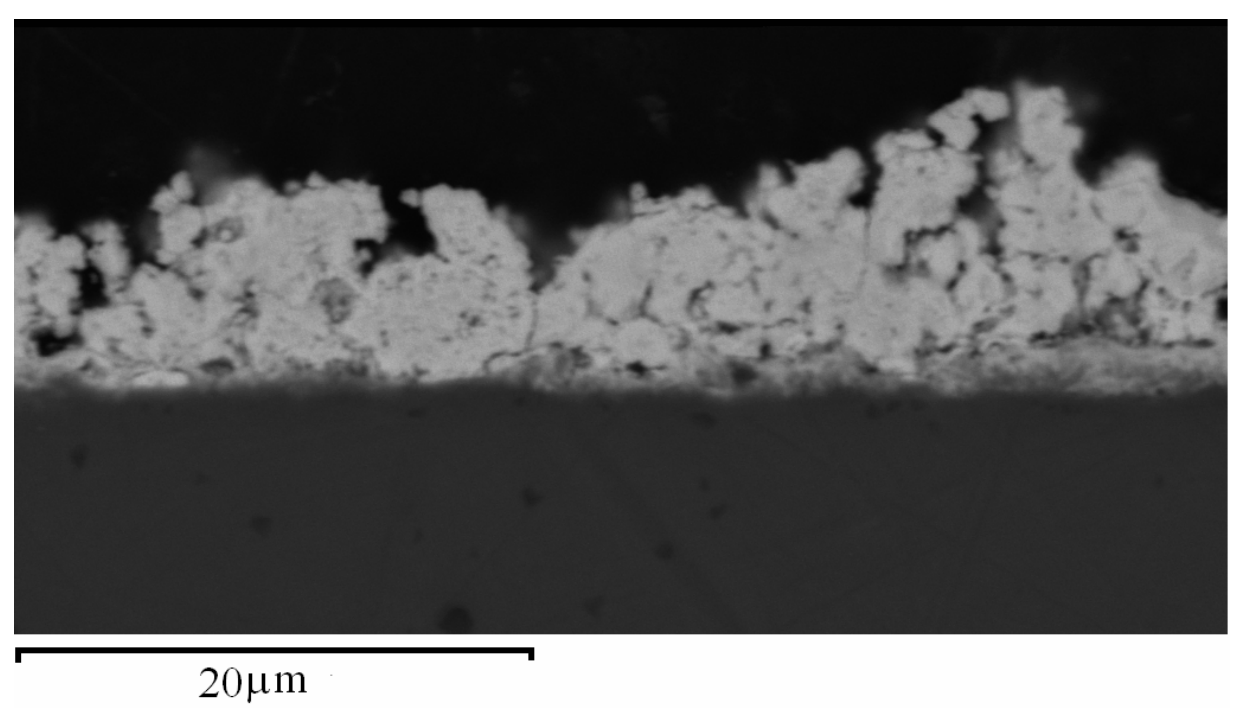

Slika 2.7. Poprečni presek PEO sloja na aluminijumu

Zahvaljujući visokim temperaturama koje prate sve PEO procese, u sastavu PEO slojeva mogu se pronaći različite kristalne strukture u zavisnosti od kombinacije elektrolita i metala [14]. PEO procesi na aluminjumu uglavnom daju dve karakteristične faze aluminijum oksida, $\alpha$ (koja je ujedno najstabilnija forma ovog oksida [32,78]) i $\gamma$ aluminu $[78,79,81,87]$. Prijavljeno je i postojanje poliamorfnih struktura $\delta$ i $\theta$ alumine. $\gamma-\mathrm{Al}_{2} \mathrm{O}_{3}$ se najjednostavnije može formirati običnom termalnom oksidacijom aluminijuma. Jednom formirana, može se direktno transformisati $\mathrm{u} \alpha$ oblik, ili preko pomenutih polimorfnih struktura, $\delta$ i $\theta$ alumine [91-93]. Prelaz iz $\gamma-\mathrm{Al}_{2} \mathrm{O}_{3} \mathrm{u} \delta-\mathrm{Al}_{2} \mathrm{O}_{3}$ zahteva temperature $\sim 1023 \mathrm{~K}$, a za prelaz iz $\delta-\mathrm{Al}_{2} \mathrm{O}_{3} \mathrm{u}$ 
$\theta-\mathrm{Al}_{2} \mathrm{O}_{3}$ neophodno je ostvariti temperature od $1273 \mathrm{~K}$. Svaka od ovih formi se na temperaturama iznad $1473 \mathrm{~K}$ transformiše $\mathrm{u}$ stabilnu $\alpha-\mathrm{Al}_{2} \mathrm{O}_{3}$, i zato je njena detekcija u PEO sloju jasni indikator da su se u toku procesa, lokalno razvile izuzetno visoke temperature.

Kristalne faze su detektovane i kod PEO procesa na magnezijumu. Izdvajaju se kristali: $\mathrm{MgO}, \mathrm{MgSiO}_{4}, \mathrm{MgSiO}_{3}$ i $\mathrm{Mg}_{3}\left(\mathrm{PO}_{4}\right)$ u zavisnosti od izbora elektrolita [74,89]. U slučaju titanijuma, uglavnom se detektuju dve faze $\mathrm{TiO}_{2}$ : anatas i rutil $[5,95]$.

\subsection{Osobine mikro pražnjenja u toku PEO procesa}

Poznavanjem osobina mikro pražnjenja (površina poprečnog preseka mikro pražnjenja, dimenzionalna distribucija, površinska gustina, temperatura i elektronske gustine u mikro pražnjenjima) može se kompletirati objašnjenje mikro struktura i osobina slojeva koji nastaju u PEO procesu, kao i kinetika njihovog rasta. Ispitivanje mikro pražnjenja podrazumeva nekoliko pristupa:

1. Snimanje pojedinačnih događaja (mikro pražnjenja) u realnom vremenu.

2. Ispitivanje električnih parametara procesa.

3. Optička emisiona spektroskopija.

4. Karakterizacija mikro struktura nastalih kao posledica mikro pražnjenja.

Snimanje pojedinačnih događaja mikro pražnjenja u realnom vremenu je moguće ostvariti upotrebom kamera čije je vreme ekspozicije bar za red veličine manje od trajanja procesa pražnjenja ( $>100 \mu \mathrm{s})$ [74]. U takvim uslovima mogu se dobiti podaci o trajanju događaja, prostornoj gustini i njihovoj distribuciji u toku vremena. Snimanjem mikro pražnjenja u realnom vremenu u toku PEO procesa na aluminijumu u alkalnom rastvoru koji sadrži silicijum, Yerokhin i saradnici [32] procenjuju da se površine poprečnih preseka mikro pražnjenja kreću u opsegu od $0.01 \mathrm{~mm}^{2}$ do $1.35 \mathrm{~mm}^{2} \mathrm{i}$ da su u toku čitavog procesa dominantna mala mikro pražnjenja $\left(\sim 0.02 \mathrm{~mm}^{2}\right)$. Populacija srednjih mikro pražnjenja dostiže svoj maksimum 35 min nakon početka (27 \%) i u završnoj fazi opada na 11 \%. Procenat velikih mikro pražnjenja u odnosu na ukupnu populaciju monotono raste kako proces odmiče i na samom kraju dostiže vrednost od 12 \%. Istovremeno, sa porastom veličine mikro pražnjenja, smanjuje se njihova prosečna površinska gustina i procenat površine koji je simultano prekriven događajima raste sa $3 \%$ na $6 \%$. 

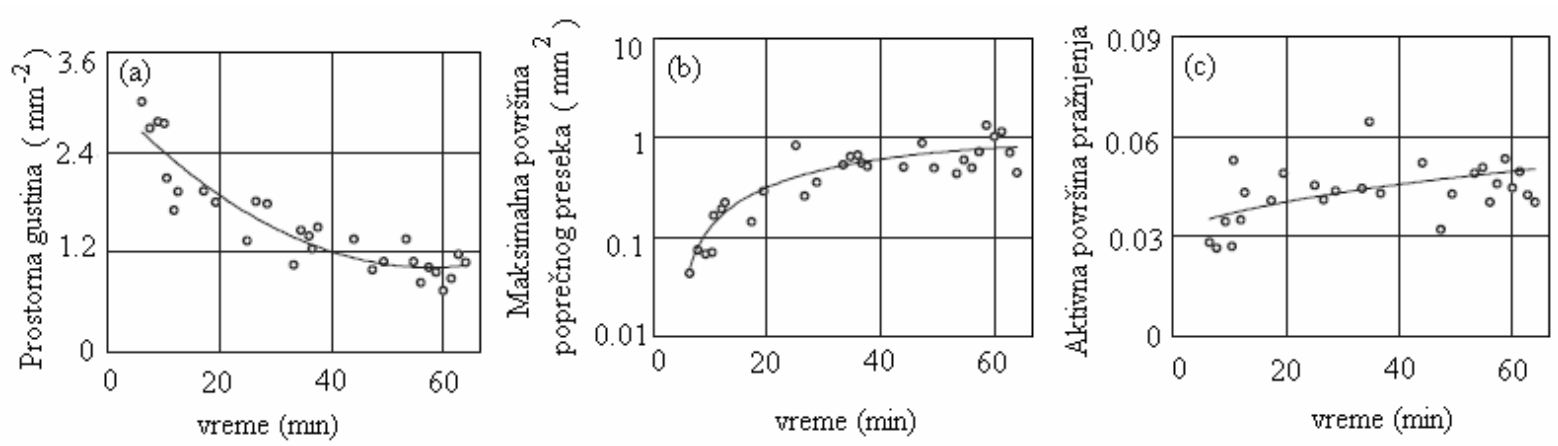

Slika 2.8. Promene karakteristika mikro pražnjenja sa PEO vremenom:

(a) površinska gustina mikro pražnjenja; (b) poprečni presek najzastupljenijih mikro pražnjenja;

(c) procenat površine prekriven aktivnim mikro pražnjenjima [32]

Matykina i saradnici [96] sprovode slično ispitivanje na titanijumu ukazujući na različite etape u razvoju mikro pražnjenja i povezujući ih sa vrednostima napona. Utvrđeno je da se u prvih nekoliko sekundi nakon početka anodizacije, na površini uzorka oslobađa samo veći broj gasnih molekula (Sl. 2.9-a). Kada napon anodizacije dostigne vrednost od $285 \mathrm{~V}$, javljaju se i prva mala mikro pražnjenja dok pri naponima od $330 \mathrm{~V}$ do $350 \mathrm{~V}$ dolazi do pojave prvih većih mikro pražnjenja oslobođenih od vazdušnog prstena (dimenzije poprečnog preseka $\sim 100 \mu \mathrm{m})$ (SI. 2.9). Kada napon anodizacije dostigne vrednosti od $430 \mathrm{~V}$, mikro pražnjenja dostižu najveću dimenziju i menjaju boju iz plave u svetlo roze. Prema Matykini prosečne dužine trajanja mikro pražnjenja kreću se u opsegu od 100 ms do 800 ms, a veličina od $80 \mu \mathrm{m}$ do $380 \mu \mathrm{m}$.

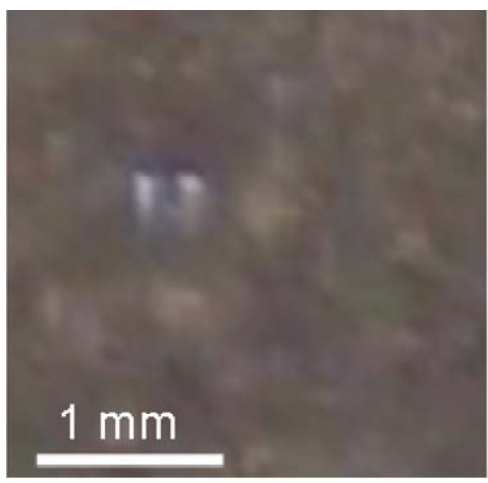

(a)

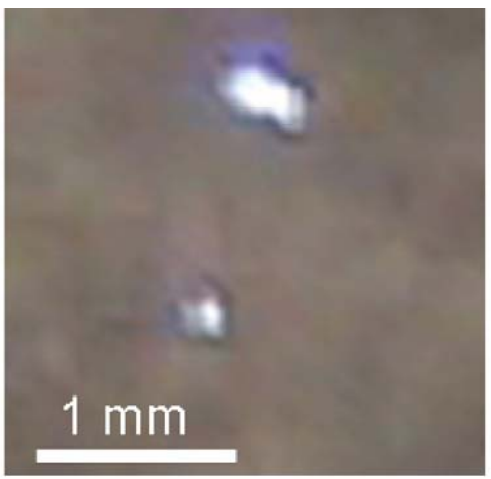

(b)

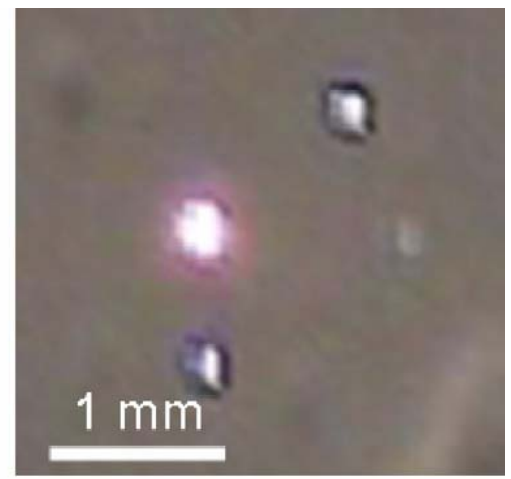

(c)

Slika 2.9. Snimci PEO procesa na titanijumu u realnom vremenu pri različitim naponima

$$
\text { ( j= } 20 \mathrm{~mA} / \mathrm{cm}^{2} \text { u } 0.026 \mathrm{M} \mathrm{Na}_{3} \mathrm{PO}_{4} \text { ): (a) } 300 \mathrm{~V} \text {; (b) } 370 \mathrm{~V} \text {; (c) } 435 \mathrm{~V} \text { [96]. }
$$


Istraživanja S. Moon-a [15] potvrđuju da se broj mikro pražnjenja vremenom smanjuje a njihova veličina raste u toku PEO procesa, nezavisno do upotrebljenog metala $\mathrm{i}$ elektrolita.

Optički emisioni spektri snimljeni u toku PEO procesa u sebi nose informacije o temperaturi i elektronskoj gustini mikro pražnjenja [33,81, 97-100]. Podaci dobijeni iz spektara atomskih i jonskih linija su upotrebljivi samo ukoliko se snimaju instrumentima visoke rezolucije. Identifikacija spektralnih linija se vrši putem dostupnih baza atomskih i jonskih linija (NIST-ove), pri čemu se vodi računa koje su mogućnosti detekcije sistema. Osnovni problem kada je u pitanju spektralna karakterizacija PEO procesa, jeste vremenska i prostorna nehomogenost pojave mikro pražnjenja na površini. U stvari PEO spektri su rezultat vremenske integracije zračenja od strane detekcionog sistema. Sve se dodatno komplikuje i kada se uzme u obzir da su intenziteti prilično niski i da je potrebno dugo vreme integracije da bi se podaci mogli iskoristiti. Sve se to prevazilazi korišćenjem spektrometara visoke svetlosne snage i niske rezolucije.

Linije koje se koriste za računanje elektronske temperature moraju pripadati istoj atomskoj ili jonskoj vrsti i biti posledica prelaza sa istog jonizacionog nivoa. Procenjene temperature mikro pražnjenja u toku PEO procesa se u velikoj meri razlikuju od istraživačke grupe do istraživačke grupe. Van i saradnici [39] je procenjuju na 800-3000 K dok Markov [101], Kurze [102] i Tcherhenko [103] daju znatno više podatke, počev od $3000 \mathrm{~K}$ do 6000 K. Grupa naučnika na čelu sa Haugil’nykh-om [104] je došla i do podatka od $10000 \mathrm{~K}$ do 20000 K. D. Kharitonov i saradnici su u svojim spektroskopskim analizama identifikovali postojanje dva tipa pražnjenja, pražnjenja u vrelom jezgru u kanalu (6800 K do $9500 \mathrm{~K})$ i u hladnijoj okolini (1600 K do $2000 \mathrm{~K}$ ) [43].

Hussein i saradnici [33], koriste relativne intenzitete Al I u cilju procene elektronske gustine i temperature mikro pražnjenja. Njihovi rezultati ukazuju da se elektronske temperature kreću u opsegu od $4500 \mathrm{~K} \pm 450 \mathrm{~K}$ do $10000 \mathrm{~K} \pm 1000 \mathrm{~K}$, podaci dobijeni iz odnosa intenziteta Al I linija koje se nalaze na $396.2 \mathrm{~nm}$ i $309.1 \mathrm{~nm}$. Uz pretpostavke da je u pitanju optički tanka plazma i da u plazmi postoji delimična termodinamička ravnoteža (LTE), moguće je iz relativnih intenziteta linija iste atomske vrste izračunati elektronsku temperaturu uz pomoć jednostavne formule (2.16) [78]:

$$
\frac{I(1)}{I(2)}=\frac{A_{m n}(1) g_{m}(1) \lambda_{0}(2)}{A_{m n}(2) g_{m}(2) \lambda_{0}(1)} \exp -\left[\frac{E_{m(2)}-E_{m(1)}}{k t}\right] \text {, }
$$


gde su:

$k t$ : termalna energija;

$I(1)$ i $I(2)$ : relativni intenziteti linija iste atomske vrste;

$A_{m n}(i)$ : verovatnoća prelaza;

$g_{m}(i)$ : statistička težina energetskog nivoa;

$E_{m}(i)$ : energija energetskog nivoa;

$\lambda_{o}(i)$ : talasna dužina u centru linije izmerena u vakumu.

Gornja jednačina je primenljiva samo ukoliko važi Boltzmann-ov zakon raspodele. $\mathrm{Na}$ osnovu jednačine (2.16) procenjeno je da se elektronske temperature kreću u rasponu od $4000 \mathrm{~K}$ do $7000 \mathrm{~K}$ i da niže elektronske temperature odgovaraju počecima pražnjenja. Hussein i saradnici u svojim proračunima zanemaruju sve efekte krajeva linija. U istoj studiji procenjene su i elektronske gustine iz Štarkovog širenja $\mathrm{H}_{\beta}$ linije na $(1.5 \pm 0.23) \cdot 10^{22} \mathrm{~m}^{-3} \mathrm{i}$ $(2.4 \pm 0.23) \cdot 10^{22} \mathrm{~m}^{-3}$.

Jovović i saradnici [105] određuju elektronske gustine u toku PEO procesa na aluminijumu koristeći linije vodonika $\mathrm{H}_{\beta}$ i $\mathrm{H}_{\alpha}$ i aluminijuma $\mathrm{Al}$ II na $704.2 \mathrm{~nm}$. Elektronske temperature određuju iz atomskih linija W I i jonskih linija kiseonika O II. U svom eksperimentu, koriste aluminijumske uzorke visoke čistoće (99.999\%). PEO proces sprovode u 0.01 M natrujum volframatu (pH-8.6) i 0.1 M limunskoj kiselini (pH-2.8) pri konstantnoj gustini struje od $50 \mathrm{~mA} / \mathrm{cm}^{2}$. Za dobijanje uskih profila linija, ova grupa istraživača koristi tri različita sistema. Za snimanje $\mathrm{H}_{\beta}$ linije niskog intenziteta opredeljuju se za sistem visoke spektralne rezolucije i visoke svetlosne moći $(0.67 \mathrm{~m}$ Cherny-Turner spektrometar sa linearnom disperzijom od $0.83 \mathrm{~nm} / \mathrm{mm}$ ). Zadovoljavajići profil $\mathrm{H}_{\alpha}$ linije snimaju na sistemu $2 \mathrm{~m}$ Eber spektrometra sa linearnom disperzijom od $0.74 \mathrm{~nm} / \mathrm{mm}$ i blejzom rešetke na $550 \mathrm{~nm}$. Odgovarajuće profile Al II linija dobijaju na instrumentu iste rezolucije ali ovoga puta sa blejzom na $750 \mathrm{~nm}$. Da bi se rezultati elektronske gustine mogli međusobno upoređivati, svi spektri su uvek snimani u istom trenutku anodizacije, sedam minuta od početka PEO procesa, sa vremenom integracije $10 \mathrm{~s}$ do $30 \mathrm{~s}$.

Na SI. 2.10. prikazan je tipični optičko emisioni spektri PEO procesa aluminijuma u limunskoj kiselini i natrijum volframatu u vidljivoj oblasti od $380 \mathrm{~nm}$ do $850 \mathrm{~nm}$. Prikazani spektri se jedino razlikuju po prisustvu dve jake linije Na I na $588.99 \mathrm{~nm}$ i $589.89 \mathrm{~nm}$ i nekoliko slabijih W I linija. 

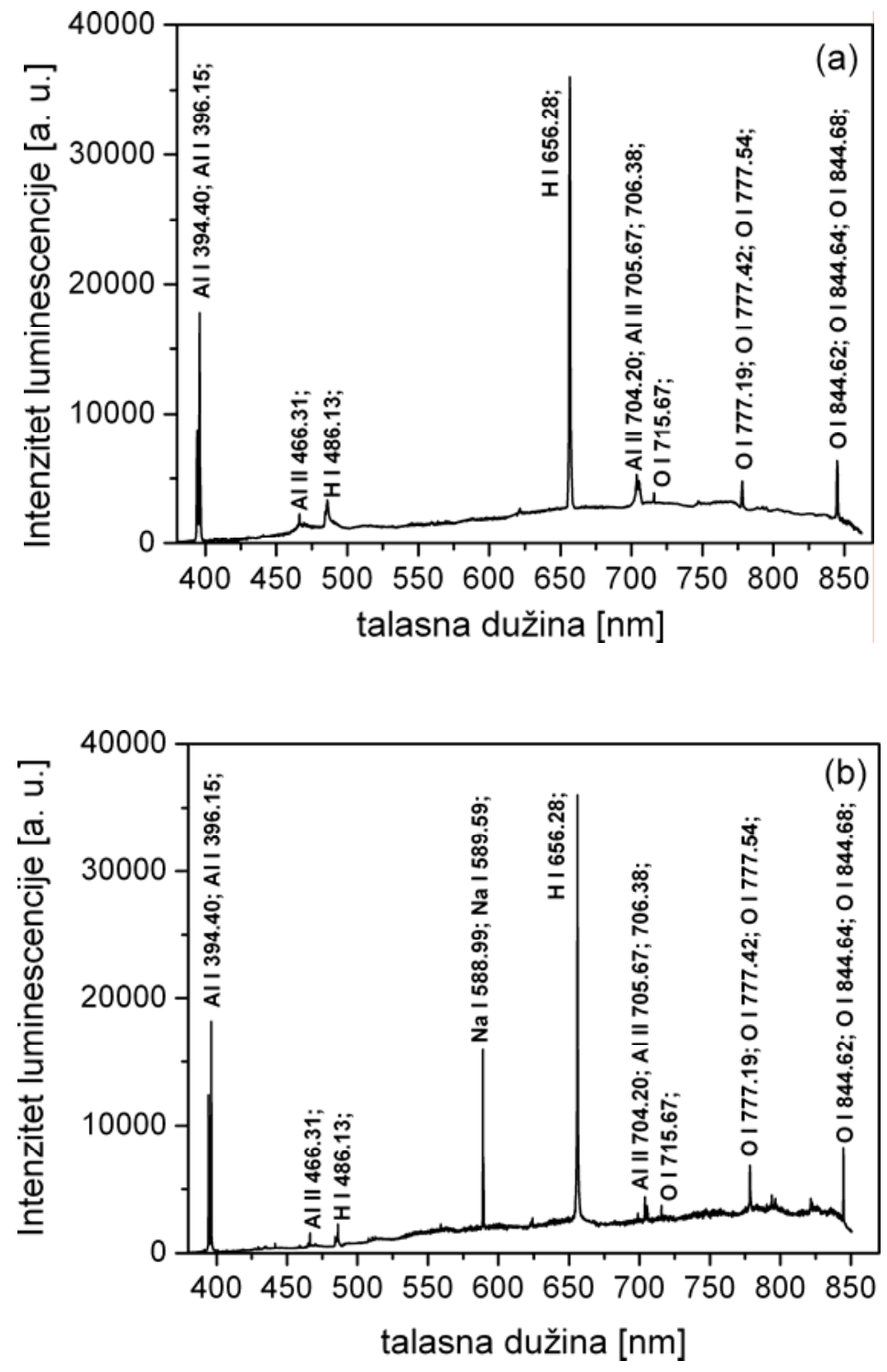

Slika 2.10. Optičko emisioni spektar PEO procesa na aluminiju u: (a) limunskoj kiselini: (b) natrijum volframatu [105].

Elektronska gustina je računata iz podataka profila $\mathrm{H}_{\beta}(486.13 \mathrm{~nm}), \mathrm{i}_{\alpha}(656.28 \mathrm{~nm})$ linija (SI. 2.11). Oblik $H_{\alpha}$ linije je moguće adekvatno fitovati samo sa dva Lorencova profila sa poluširinama na polovinama maksimuma (FWHM) od $0.1 \mathrm{~nm}$ i $0.6 \mathrm{~nm}$. Ovim Lorencovim profilima odgovaraju elektronske gustine od $\mathrm{Ne}=0.7 \cdot 10^{16} \mathrm{~cm}^{-3}$ i $\mathrm{Ne}=1.0 \cdot 10^{17} \mathrm{~cm}^{-3}[106]$. Ipak, i pored visokog kvaliteta fitovanja ove rezultate treba uzeti sa rezervom zbog postojanja visoke samoapsorpcije $\mathrm{H}_{\alpha}$ linije koja utiče na širenje krajeva profila i ne daje pouzdane rezultate elektronske gustine. Postojanje izrazite samoapsorpcije $\mathrm{H}_{\alpha}$ linije je moguće potvrditi nakon analize profila $\mathrm{H}_{\beta}$ linije. Uprkos inteferenciji sa trakom AlO radikala (Sl 2.11-b.), 
gornji deo profila ove linije omogućava dobru procenu poluširine na $0.17 \mathrm{~nm}$ i to odgovara elektronskoj gustini $\mathrm{Ne}=0.8 \cdot 10^{15} \mathrm{~cm}^{-3}$ (procenjena greska je $\pm 20 \%$ ).

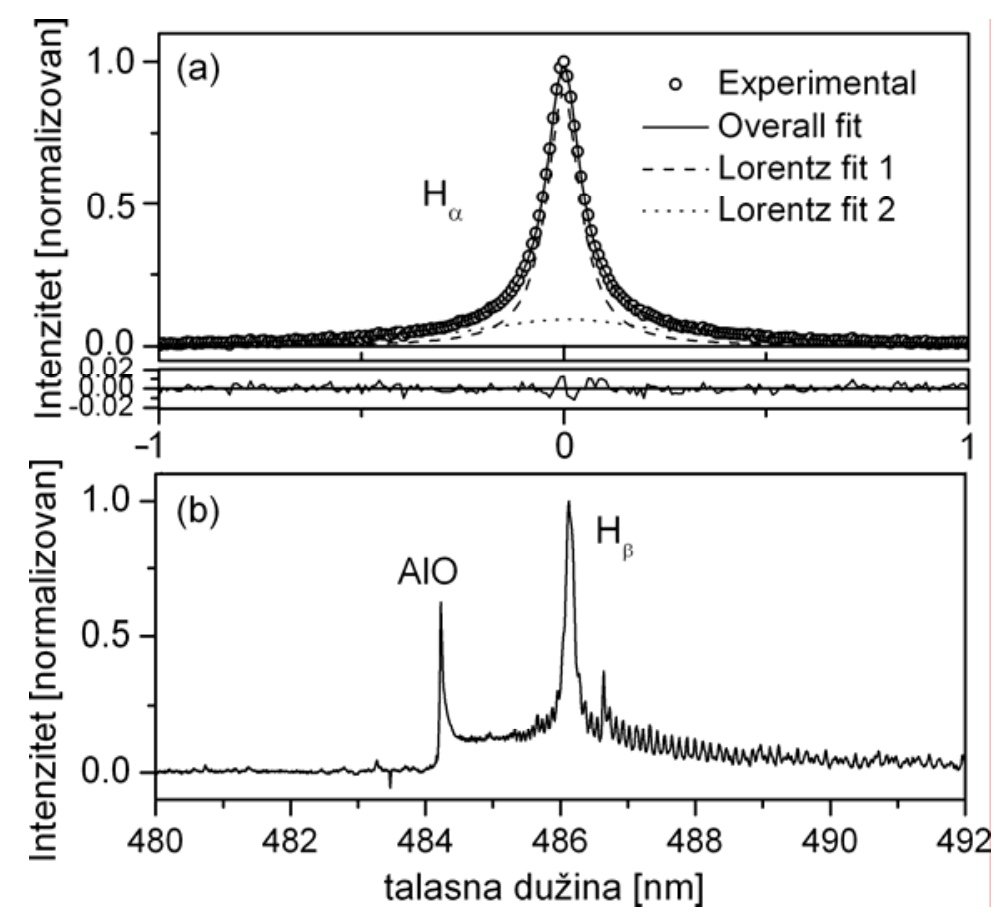

Slika 2.11. (a) Eksperimentalni profil $H_{\alpha}$ linije, fitovan sa dva Lorentz-ova profila; b) $H_{\beta}$ linija u blizini $A l O$ trake [105].

Uticaj trake AlO radikala na niže delove profila $\mathrm{H}_{\beta}$ linije je moguće izbeći korišćenjem nekog drugog ventilnog metala kod koga se neće javljati molekulske trake u blizini. Korišćenjem profila $\mathrm{H}_{\beta}$ linije u slučaju PEO procesa na tantalu dobijaju se elektronske gustine $\mathrm{Ne}=2.2 \cdot 10^{16} \mathrm{~cm}^{-3}$ (procenjena greška je $\pm 30 \%$ ) [105]. Oba rezultata su značajno niža od rezultata koji je dobijen fitovanjem profila $\mathrm{H}_{\alpha}$ linje potvrđujući da se uticaj samoapsorpcije ne može zanemariti.

Korišćenjem uskog profila $\mathrm{H}_{\beta}$ linije moguće je izvući još jedan zaključak-pobuđeni vodonikovi atomi imaju nisku Doppler-ovu temperaturu koja ne prelazi $3000 \mathrm{~K}$. Da je drugačije, mogao bi, umesto Lorencovog da se pojavi Voight-ov profil [108]. Detektovanje tako niskih temperatura se slaže sa procenom temperature $\mathrm{OH}$ radikala od strane Dunleavy-a [97] što dokazuje da se pražnjenja događaju u malim kanalima na površini metala.

Elektronske gustine je moguće izračunati i korišćenjem profila Al II linije koji odgovara multipletu broj 3. (prelaz: $3 \mathrm{~s} 4 \mathrm{~s}-3 \mathrm{~s}\left({ }^{2} \mathrm{~S}\right) 4 \mathrm{p}$ ), SI. 2.12 [105]. Za poluširinu od $0.08 \mathrm{~nm}$, 
dobijene su elektronske gustine: $N e=5 \cdot 10^{16} \mathrm{~cm}^{-3}$ i $N e=7.5 \cdot 10^{16} \mathrm{~cm}^{-3}$, tj. srednja vrednost sa greškom od $20 \%, N e \sim 6.0 \cdot 10^{16} \mathrm{~cm}^{-3}$. Rezultati su dobijeni za elektronske temperature od $40000 \mathrm{~K}[105]$.

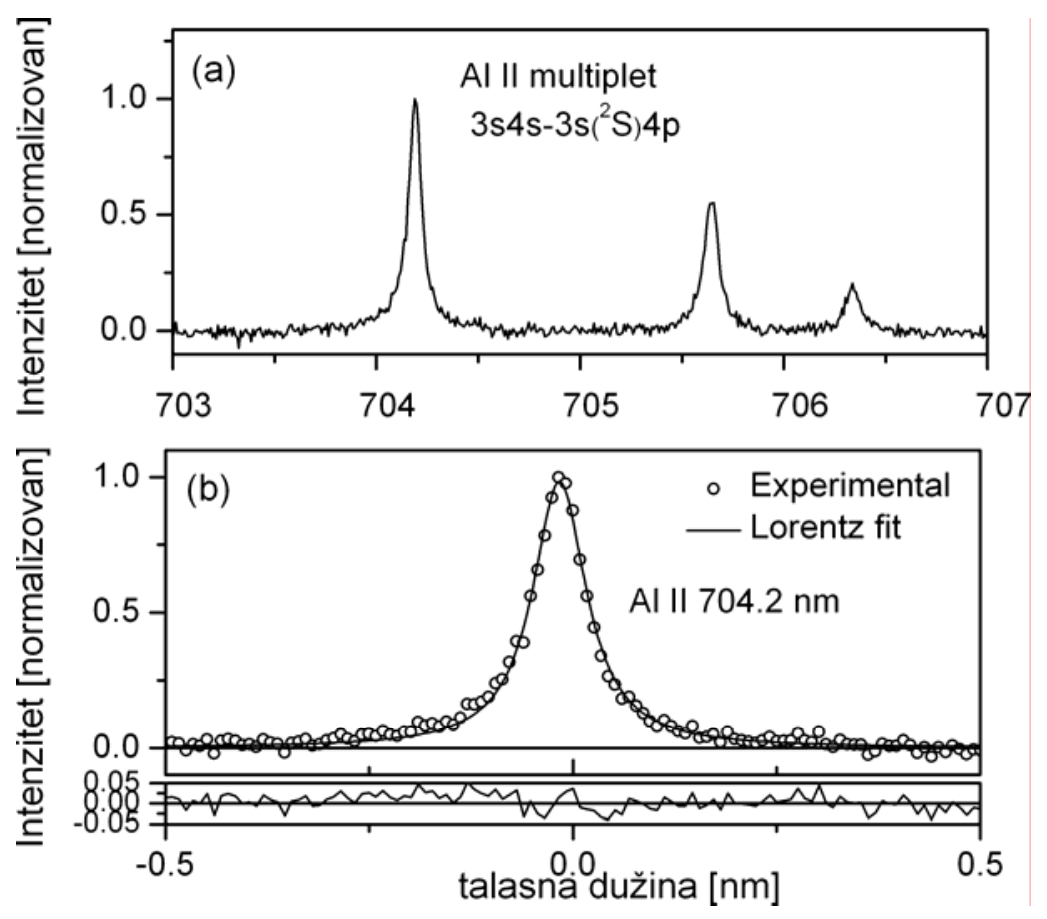

Slika 2.12. (a) $3 s 4 s-3 s(2 S) 4 p$ multiplet Al II; (b) eksperimentalni profil Al II linije na $704.2 \mathrm{~nm}$ sa najboljim mogućim fitovanjem [105].

Jonske linije kiseonika O II su prisutne u toku čitavog procesa sa slabim intenzitetima pa su samim tim oslobođene od samoapsorpcije. Ipak i one nisu najidealnije rešenje jer se koncentracija kiseonika $u$ toku PEO procesa značajno menja i može uticati na procenu elektronske temperature [109]. Boltzmann-plot tehnika za O II linije daje elektronske temperature od oko $40000 \mathrm{~K}$, dok se iz W I linija dobija elektronska temperatura od oko 3300 $\mathrm{K}$.

Temperatura mikro pražnjenja se može proceniti i iz intenziteta vibracione trake AlO. Jedna takva studija sprovedena je od strane Stojadinovića i saradnika u toku PEO oksidacije aluminijuma u limunskoj kiselini [110]. Luminescentni spektar u opsegu talasnih dužina od $500 \mathrm{~nm}$ do $556 \mathrm{~nm}$ (talasnih brojeva od $18000 \mathrm{~cm}^{-1}$ do $20000 \mathrm{~cm}^{-1}$ ) [110] dat je na SI. 2.13. AlO traka u luminescentnom spektru poslužila je za proračun relativne populacije vibracionih nivoa $\mathrm{B}^{2} \Sigma^{+}$elektronskog stanja a odatle i za procenu temperature mikro pražnjenja. 


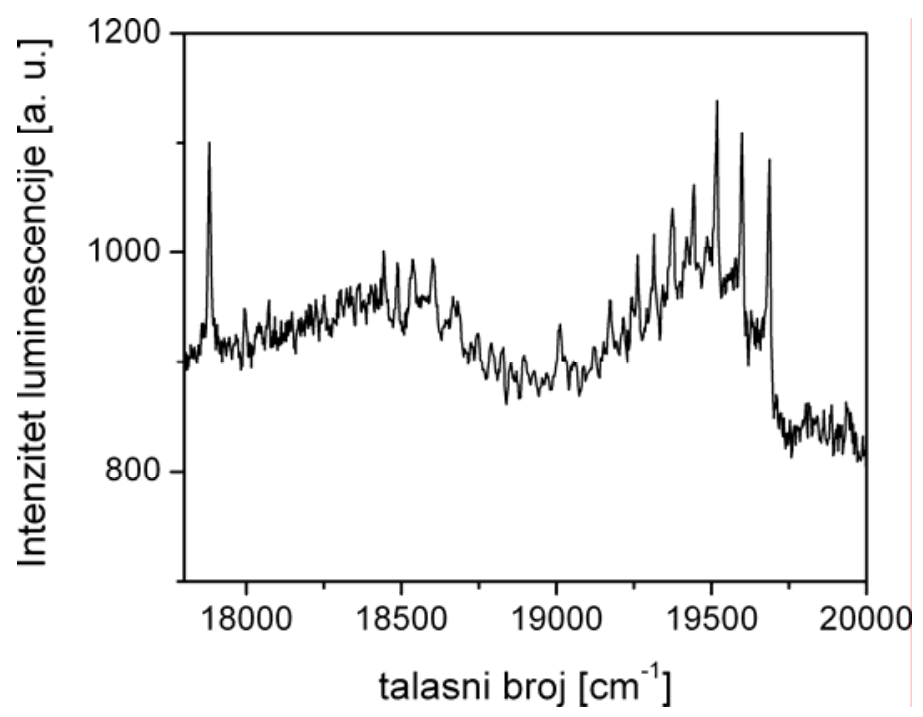

Slika 2.13. Luminescentni spektar PEO oksidacije aluminijuma u oblasti talasnih brojeva od $18000 \mathrm{~cm}^{-1}$ do $20000 \mathrm{~cm}^{-1}$ [110].

Uz pretpostavku postojanja termalne ravnoteže i računanjem odgovarajućih F-C fakora (Franck-Condon) i vibracionih prelaznih momenata (TM), moguće je dobiti informaciju o populaciji $\mathrm{B}^{2} \Sigma^{+}$elektronskog stanja, a odatle i temperaturu plazme.

Na Sl. 2.14 prikazane su vrednosti relativne naseljenosti $\mathrm{B}^{2} \Sigma^{+}$elektronskog stanja, za $v^{\prime}=0,1,2,3,4,5$. Oznakom F-C su naznačeni eksperimentalni rezultati F-C faktora objavljeni od strane Londhe [111], F-C $\mathrm{C}_{\exp }$ su podaci dobijeni od strane Stojadinovića i saradnika, računati preko molekulskih parametra objavljenih od strane Saksena-e [112]. TM su podaci dobijeni računanjem vibracionih prelaznih momenata putem parametara takođe publikovanih od strane Saksena-e, dok su odgovarajući elektronski momenti računati ab initio teorijom [113]. Odgovarajuće temperature na osnovu podataka o populaciji su: $\sim 8000 \mathrm{~K}$ (FC podaci), $\sim 6800 \mathrm{~K}$ (F-C $\mathrm{C}_{\exp }$ podaci) i $\sim 9400 \mathrm{~K}$ (TM podaci). Primećuje se da su F-Cexp podaci za više od $1000 \mathrm{~K}$ razlikuju od $\mathrm{F}-\mathrm{C}$ podataka, dok se uzimanjem u obzir promena elektronskih prelaznih momenata sa dužinom veze, procenjene temperature skoro $1500 \mathrm{~K}$ više od F-C podataka, gde oni nisu razmatrani. Kombinacijom sva tri rezultata, pomenuta temperatura mikro pražnjenja se procenjuje na $8000 \mathrm{~K} \pm 2000 \mathrm{~K}$. 

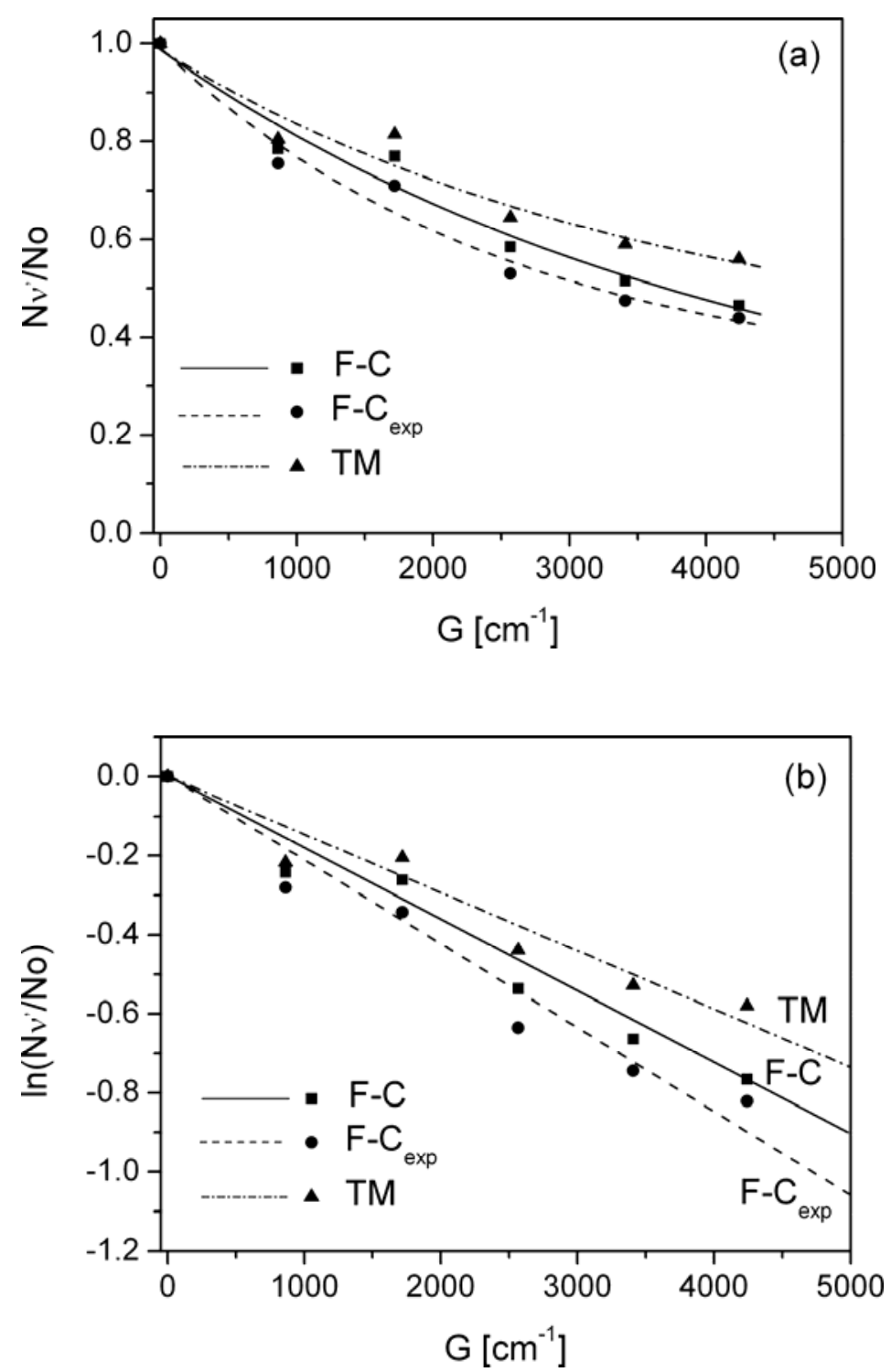

Slika 2.14. (a) Relativna naseljenost vibracionih nivoa $B^{2} \Sigma^{+}$elektronskog stanja, $v^{\prime}=0,1,2,3,4,5$ ( na slici sa leva na desno) izračunata na osnovu distribucije intenziteta snimljene trake; (b) logaritam relativne naseljenosti vibracionih nivoa $v^{\prime}=0,1,2,3,4,5$ u funkciji odgovarajuće vrednosti termova [110].

Eksperimentalni intenziteti spektralnih linija izračunati na osnovu F-C faktora i uz pretpostavku temperature od $8000 \mathrm{~K}$ prikazani su na Sl. 2.15. Sa slike se jasno vidi da rezultati dobijeni ovim proračunom daju veoma dobro slaganje sa eksperimentalnim rezultatima.

Temperatura od $8000 \mathrm{~K}$ je u stvari vibraciona temperatura. U slučaju termalne ravnoteže, na temperaturi od $8000 \mathrm{~K}$, naseljenost $\mathrm{B}^{2} \Sigma^{+}$stanja je samo $3 \%$ u odnosu na osnovno elektronsko stanje. To je dovoljno da dovede do pojave emisionog spektra AlO 
radikala, ako su oni prisutni u dovoljnoj koncentraciji na tako visokim temperaturama. Serija rezultata proračuna sastava plazme za odnos $\mathrm{Al}: \mathrm{O}=2: 3$ i temperature do $11000 \mathrm{~K}$ data je na SI. 2.16 [110].

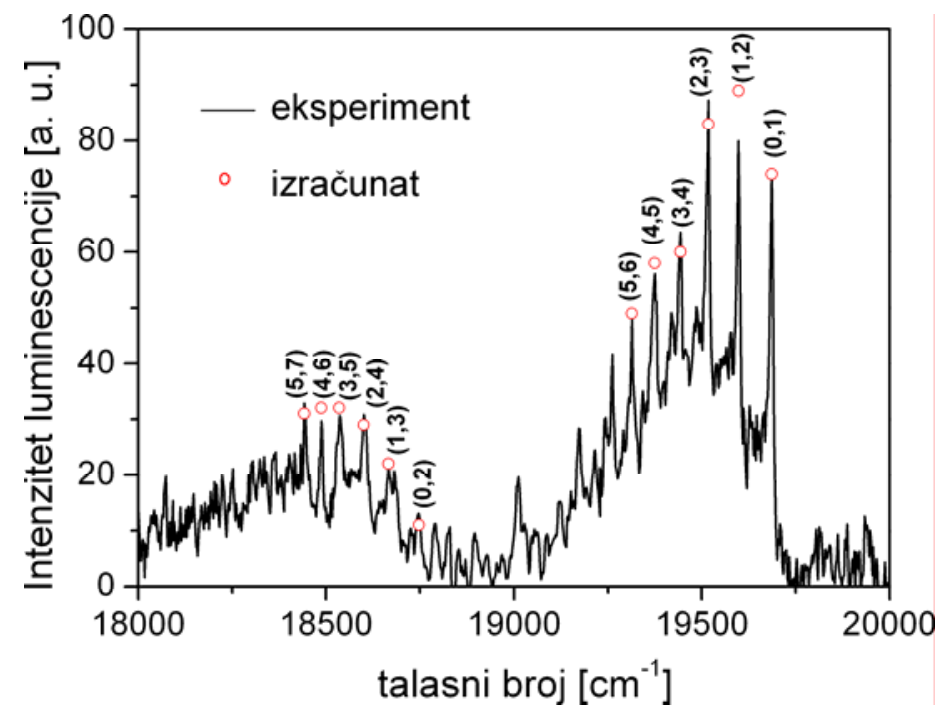

Slika 2.15. Eksperimentalni luminescentni spektar koji odgovara elektronskom prelazu $\mathrm{B}^{2} \Sigma^{+}-\mathrm{X}^{2} \Sigma^{+} \mathrm{AlO}$ sistema, $v^{\prime}-v^{\prime}{ }^{\prime}=-1$ i -2 nakon oduzetih doprinosa anodne luminescencije. Kružićima su označeni maksimumi izračunati na osnovu procenjene naseljenosti $\mathrm{B}^{2} \Sigma^{+}$stanja [110].

Na temperaturi od $8000 \mathrm{~K}$, sastav plazme čine $\mathrm{Al}$ atomi i $\mathrm{Al}^{+}$joni (99.96\%), dok ostatak od $\sim 0.04 \%$ priprada pomenutom AlO sistemu. To je dovoljno visoka koncentracija da se u spektru jave trake AlO radikala. Situacija se ne menja značajnije ni na nešto širem temperaturnom opsegu. Primećuje se samo da se koncentracije atomskog $\mathrm{Al}$ i jonskog $\mathrm{Al}^{+}$ izjednačavaju na temperaturi od $9000 \mathrm{~K}$, a da je jonska vrsta dominantnija na višim temperaturama. Izračunata elektronska gustina na $8000 \mathrm{~K}$ iznosi $\sim 1.2 \cdot 10^{17} \mathrm{~cm}^{-3}$ (i praktično je jednaka elektronskoj gustini $\mathrm{Al}^{+}$jona), dok su na temperaturama od $6000 \mathrm{~K}$ i $10000 \mathrm{~K}$ elektronske gustine oko $1.4 \cdot 10^{16} \mathrm{~cm}^{-3}$ i $1.7 \cdot 10^{17} \mathrm{~cm}^{-3}$, respektivno. Ove vrednosti se značajno razlikuju od elektronskih gustina procenjenih od strane Jovovića i saradnika [105]. 

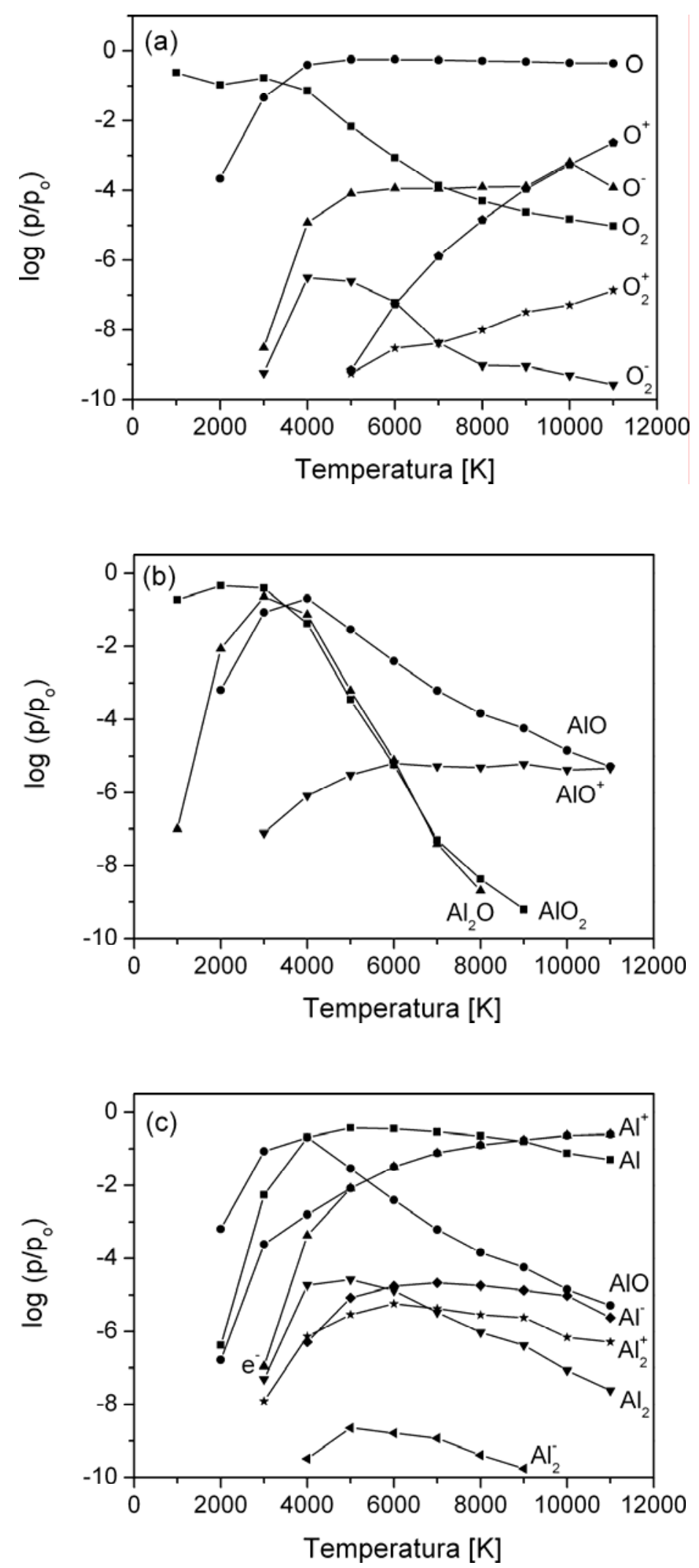

Slika 2.16. Ravnotežni sastav plazme za smešu aluminijuma i kiseonika u molskom odnosu 2:3.

(a) Molekulske vrste sa kiseonikom; (b) Molekulske vrste koje sadrže i aluminijum i kiseonik;

(c) Molekulske vrste koje sadrže isključivo aluminijum, AlO i elektrone [110]. 
Termalni uticaj energije koja se oslobodi u toku mikro pražnjenja na PEO sloj, tj. moguće povećanje temperature oksidnog sloja, može se proceniti na osnovu jednačine (2.17) [32]:

$$
\Delta T=q \frac{\chi}{\lambda V_{i}}
$$

U pomenutoj jednačini $V_{i}$ je zapremina oksidnog sloja zagrejanog od strane mikro pražnjenja, $\chi$ je termalna difuzivnost i u slučaju aluminijuma iznosi $6.9 \cdot 10^{-7} \mathrm{~m}^{2} \mathrm{~s}^{-1}, \lambda$ je toplotna provodljivost $\left(3.35 \mathrm{Wm}^{-1} \mathrm{~K}^{-1}\right)$, a $q$ specifičan otpor na temperaturi od $1073 \mathrm{~K}$ $\left(3.5 \cdot 10^{6} \Omega \mathrm{m}\right)$ [114]. Promenjiva veličina $q$ zavisi od gustine struje jednog događaja, odnosno mikro pražnjenja, i njena srednja vrednost se može proceniti deljenjem ukupne gustine struje za neki kratak vremenski period sa površinom koja je u tom kratkom intervalu izložena događajima mikro pražnjenja. Moguće povećanje temperature sloja prema jednačini (2.17) dato je na Sl. 2.17.

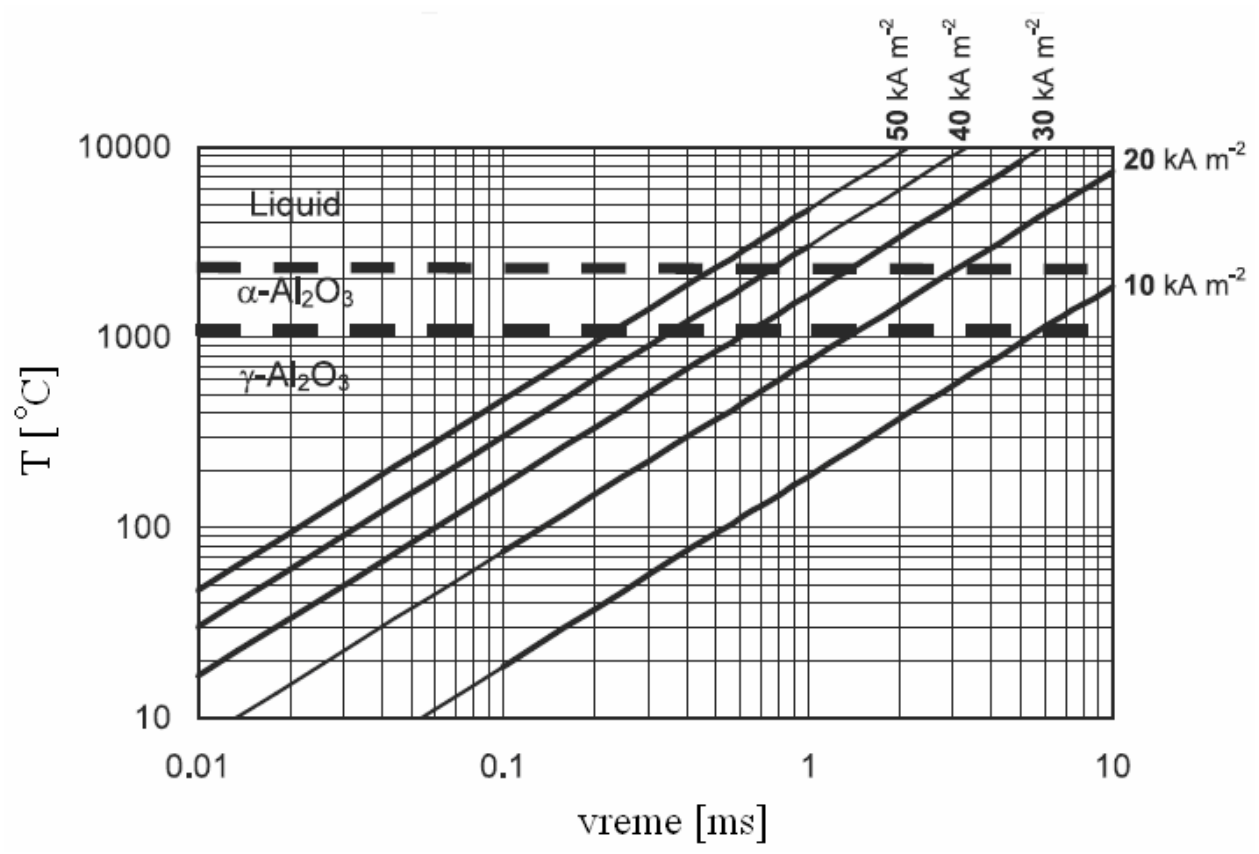

Slika 2.17. Procenjeno povećanje temperature PEO sloja u zavisnosti od gustine struje pojedinačnog mikro pražnjenja [32]

Praćenje električnih parametara u toku procesa omogućava direktno merenje: struje mikro pražnjenja, trenutne ukupne snage koja se oslobodi, ukupnog naelektrisanje koje se 
prenosi u toku procesa i energije koja se pritom utroši. Pošto su električna merenja podložna uticaju spoljnih parametara, treba biti izuzetno pažljiv u tumačenju rezultata i poznavati sve uticajne veličine.

U pomenutoj studiji procene termalnog uticaja procesa na PEO sloj [32] merenjem ukupne gustine struje u nekom definisanom vremenskom intervalu, Yerokhin i saradnici su izračunali srednju gustinu struje koja se oslobodi u toku jednog mikro pražnjenja (od $18 \mathrm{kAm}^{-2}$ do $50 \mathrm{kAm}^{-2}$ za dužinu događaja $\leq 7.5 \mathrm{~ms}$ ) i primetili da ta vrednost monotono opada sa vremenom PEO procesa.

Rezultati osciloskopskih merenja promene napona i struje izolovanog događaja mikro pražnjenja u završnoj fazi PEO procesa na aluminijumu prikazani su na Sl. 2.18 [115]. Izmereno je postepeno smanjenje napona $(\sim 200 \mathrm{mV}) \mathrm{u}$ toku perioda od $\sim 1 \mu \mathrm{s}$. Procenjene su dimenzije mikro pražnjenja na osnovu dimenzija kanala na PEO površini (površina poprečnog preseka $\sim 10^{-4} \mathrm{~mm}^{2}$ ) i na osnovu svih tih podataka aproksimirana je prosečna energija koja se oslobodi po događaju $\sim 0.2 \mu \mathrm{J}$ i prosečna gustina struje $\sim 10^{9} \mathrm{~A} / \mathrm{m}^{2}$.

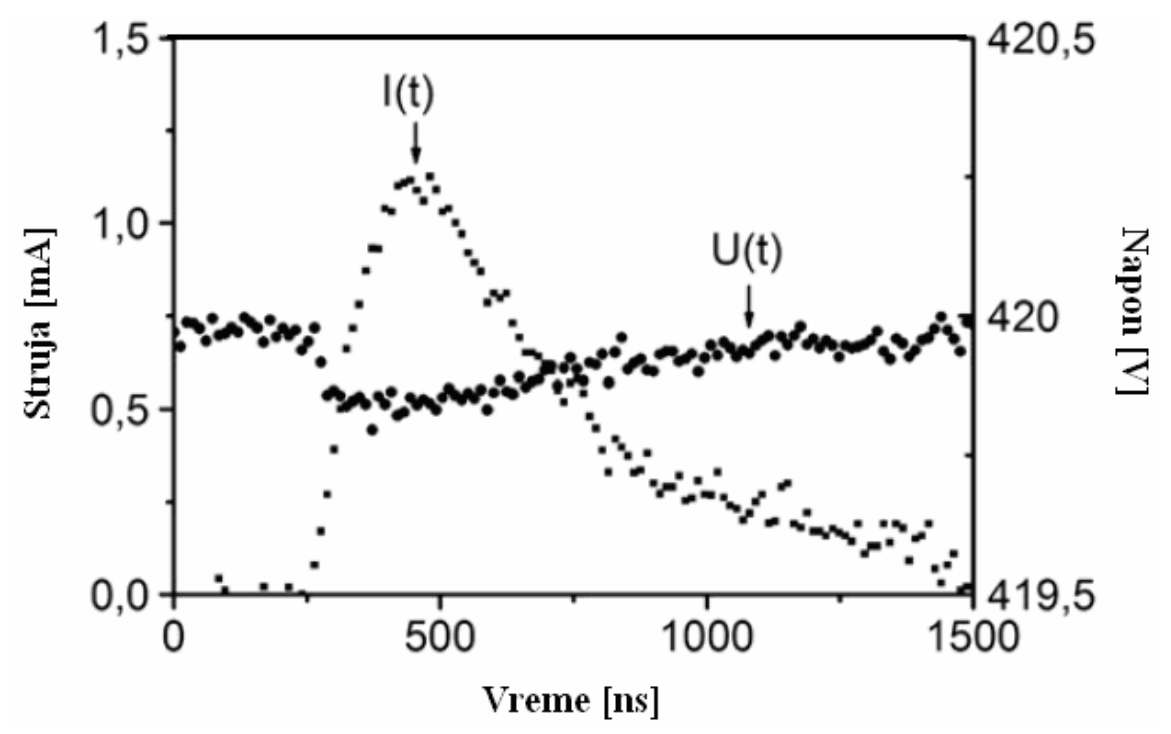

Slika 2.18. Promene u struji i naponu u toku jednog događaja mikro pražnjenja na [115]

Bao Van i saradnici [39] u slučaju dva izolovana događaja mikro pražnjenja dolaze do znatno viših podataka o vremenu trajanja mikro pražnjenja 200 $\mu \mathrm{s}$, dok je vremenski period između dva uzastopna mikro pražnjenja procenjen na $\sim 300 \mu$ s. Ova grupa istraživača je dobila podatke i o srednjog gustini struje u opsegu od $2.1 \cdot 10^{8} \mathrm{~A} / \mathrm{m}^{2}$ i $2.83 \cdot 10^{8} \mathrm{~A} / \mathrm{m}^{2}$. 
Tabela 2.1. Podaci o vremenu života mikro pražnjenja iz različitih izvora

\begin{tabular}{|c|c|c|c|}
\hline Substrat & Metoda merenja & Vreme života $[\mu \mathrm{s}]$ & Izvor \\
\hline Nikl & Električna merenja & $\sim 200$ & [39] \\
\hline Aluminijum & Električna merenja & $\sim 1$ & [81] \\
\hline \multirow[t]{2}{*}{ Magnezijum } & Električna merenja & $50-1100$ & {$[74]$} \\
\hline & & $10-100$ & [97] \\
\hline \multirow[t]{2}{*}{ Aluminijum } & Optička merenja & $100-500$ & [49] \\
\hline & & $10-20$ & {$[117]$} \\
\hline Titanijum & Električna merenja & $10-20$ & {$[118]$} \\
\hline Titanijum & Električna merenja & $\leq 7500$ & [119] \\
\hline Titanijum & Optička merenja & $35000-800000$ & [96] \\
\hline Aluminijum & Teorija & $250-3500$ & {$[32]$} \\
\hline
\end{tabular}

Tabela 2.2. Prosečna gustina struje po događaju mikro pražnjenja za različite substrate

\begin{tabular}{l|c|c}
\hline \multicolumn{1}{c|}{ Substrat } & $\begin{array}{c}\text { Prosečna gustina struje po } \\
\text { događaju A } / \mathrm{m}^{2}\end{array}$ & Izvor \\
\hline Nikl & $2.1 \cdot 10^{8}, 2.83 \cdot 10^{8}$ & {$[39]$} \\
Aluminijum & $\sim 10^{9}$ & {$[115]$} \\
Aluminijum & $2 \cdot 10^{4}-5 \cdot 10^{4}$ & {$[32]$} \\
& $1 \cdot 10^{7}, 3 \cdot 10^{8}$ & {$[121]$} \\
Aluminium & $2 \cdot 10^{8}$ & {$[120]$} \\
\hline
\end{tabular}


Novija istraživanja Arrabal-a sa saradnicima [74] pružaju bolji uvid u vezu između električnih parametra i mikro pražnjenja. Oni su u slučaju PEO procesa na magnezijumu uspeli da sinhronizuju optičku detekciju jednog događaja i vrednosti električnih parametra struje i napona. Za praćenje mikro pražnjenja, koristili su ultrabrze kamere koje snimaju od 1000-20000 frejmova u sekundi i došli su do podatka da vremena trajanja mikro pražnjenja leže u opsegu od $0.05 \mathrm{~ms}$ do $0.185 \mathrm{~ms}$. Najduže izmerena vremena su u opsegu od $\leq 1 \mathrm{~ms}$ do $\leq 4 \mathrm{~ms}$, dok je prosečno vreme u toku PEO procesa od 0.5-1.1 ms. Potvrdili su i da se u slučaju PEO procesa na magnezijumu populacija tih dugoživećih mikro pražnjenja povećava kako proces napreduje.

Dunleavy i saradnici prijavljuju vremenske intervale $\sim 10 \mu$ s do $100 \mu$ s [97]. Slične rezultate prijavljuju i Long [116], Snizhko [117] i Gnedenkov [118]. Tabelarni prikaz različitih istraživačkih grupa o vremenskom intervalu trajanja mikro pražnjenja dat je u Tabeli 2.1, a u Tabeli 2.2. dat je tabelarni prikaz prosečnih gustina stuje izolovanih događaja na različitm substratima. 


\section{EKSPERIMENTALNA METODA}

U ovom poglavlju biće opisane metode i instrumenti korišćeni za ispitivanje osobina mikro pražnjenja i morfologije PEO slojeva na ventilnim metalima. Detaljniji eksperimentalni uslovi anodizacije pojedinačnih metala u smislu: predtretmana, primenjenje gustine struje, temperature i vrste elektrolita, biće dati u okviru zasebnih poglavlja sa eksperimentalnim rezultatima.

\section{1. Ćelija za anodizaciju sa sistemom za termostatiranje elektrolita}

Uzorci svih ventilnih metala su anodizirani u elektrolitičkoj ćeliji prikazanoj na Sl. 3.1. Ćelija se sastoji od staklene kivete sa ravnim prozorima dimenzija $40 \mathrm{~mm}$ x $50 \mathrm{~mm}$ x $70 \mathrm{~mm}$, nosača za anodu koji omogućava postavljanje uzorka ventilnog metala (1) u željeni položaj, dve platinske žice kao katode (2) i PTC senzora zalivenog u teflonsku cevčicu koji služi za merenje temperature elektrolita u blizini uzorka. Prilikom PEO procesa dolazi do promene temperature i isparavanja elektrolita, te je potrebno izvršiti njegovo termostatiranje. Aparatura za termostatiranje elektrolita sastoji se od peristatičke pumpe (4) i razmenjivača toplote (5).

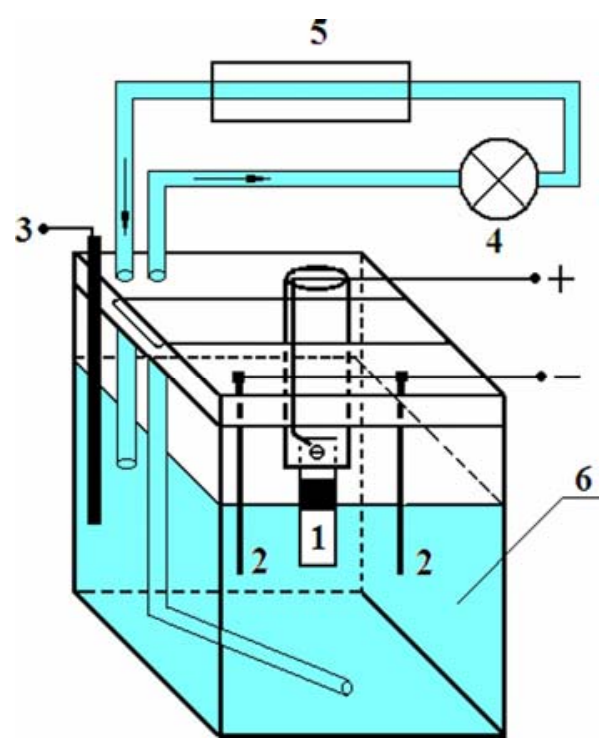

Slika 3.1. Šematski prikaz ćelije za anodizaciju 


\subsection{Spektralna karakterizacija PEO procesa}

Spektralna karakterizacija PEO procesa je izvršena pomoću spektrografskog sistema zasnovanom na ICCD kameri (Intensified Charge Coupled Device), namenjenom za vremenski razložena merenja slabih svetlosnih intenziteta u širokom opsegu talasnih dužina. Optičko detekcioni sistem sastoji se od ulazne optike, optičkog spektrografa sa difrakcionom rešetkom od 1200 zareza/mm (opsega od $43 \mathrm{~nm}$ ) i veoma osetljive ICCD hlađene kamere, visoke kvantne efikasnosti u vidljivom delu spektra, proizvođača Princeton Instruments (SI. 3.2). CCD čip se sastoji od 620 × 256 aktivnih piksela, svaki dimenzija $26 \mu \mathrm{m}$ x $26 \mu \mathrm{m}$. Da bi se smanjila struja mraka, CCD čip je hlađen na $-40^{\circ} \mathrm{C}$. Optičko detekcioni sistem je korišćen za više položaja difrakcione rešetke, sa preklapanjem od $10 \mathrm{~nm}$. Time je omogućeno snimanje emisionih spektara u opsegu od $380 \mathrm{~nm}$ do $850 \mathrm{~nm}$.

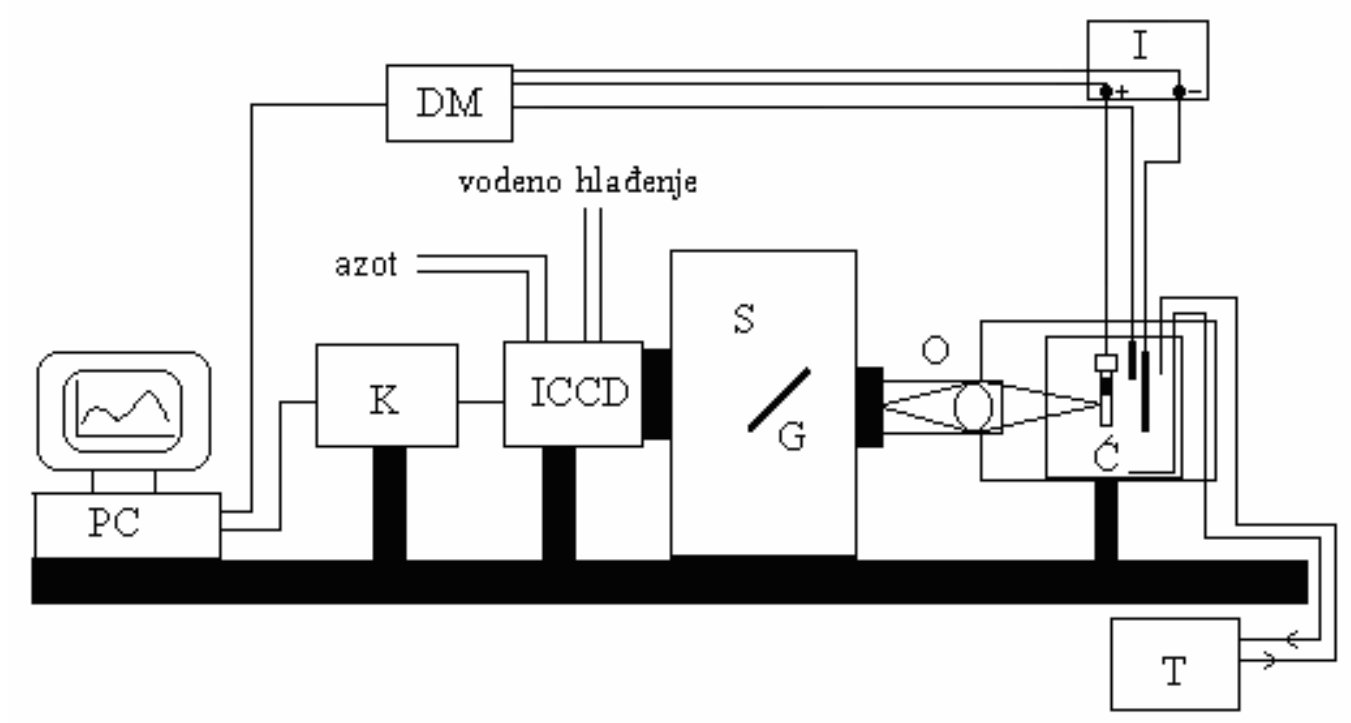

Slika 3.2. Šematski prikaz aparature za spektralnu karakterizaciju PEO procesa: I - izvor napajanja, Ć - ćelija za elektrolizu, T - sistem za termostatiranje elektrolita, O - ulazna optika, S - spektrograf, G - difrakciona rešetka (1200 zareza/mm), ICCD kamera ( tip PI MAX:1024), K - kontroler ST 133, DM - višekanalni digitalni multimetar HP 34970A, PC - računar.

Za dobijanje spektara veće rezolucije kod anodizacije uzoraka titanijuma korišćen je Czerny-Turner spektrometar (McPherson, Model 207, f/4.7, inverzna linearna disperzija $0.83 \mathrm{~nm} / \mathrm{mm}$ ) sa CCD detektorom hlađenim na $-10{ }^{\circ} \mathrm{C}$. Ovaj sistem omogućava dobijanje linija profila vrlo bliskog Gausovom sa poluširinom od $0.030 \mathrm{~nm}$. 


\subsection{Karakterizacija mikro pražnjenja u realnom vremenu}

Snimanje PEO procesa u realnom vremenu (real-time images) ostvareno je pomoću kamere DCR-DVD110 (800K pixela CCD, 40x optički zum i žižne daljine filtera 40 mm), proizvođača Sony. Vremenska rezolucija merenja ograničena je intervalom između dva frejma od $40 \mathrm{~ms}$ i brzinom otvora od 1/100 s. Sve informacije su odvojene po frejmovima i svaki od njih je obrađen softverom koji je izrađen u samoj laboratoriji. Softver omogućava prebrojavanje mikro pražnjenja po frejmu i određivanje prostorne gustine pražnjenja uzimajući u obzir i njihovu dimenzionalnu distribuciju.

\subsection{Karakterizacija oksidnih slojeva dobijenih PEO procesom}

Morfologija i hrapavost dobijenih oksidnih slojeva ispitivani su na AFM-u (Atomic Force Microscopy; Veeco Instruments, model Dimension V). Odgovarajući mikrografi su dobijeni u tapping modu u ambijentalnim uslovima uz upotrebu tipova TAP300 (rezonantna frekvencija $300 \mathrm{kHz}$ i konstanta sile $40 \mathrm{~N} / \mathrm{m}$ ). Podaci o hrapavosti su dobijeni korišćenjem softvera diNanoScope, verzija 7.0.

Hemijski sastav dobijenih slojeva ispitivan je skenirajućim elektronskim mikroskopom (SEM), JOEL 840A sa dodatkom za EDS analizu (EDS-Energy Dispersive Spectroscopy.

Kristalnost i fazni sastav uzoraka su analizirani XRD instrumentom Phillips PW 1050 u Bragg-Brentano geometriji sa Ni-filtriranim $\mathrm{CuK}_{\alpha}(\lambda=1.54178 \mathrm{~A})$ zračenjem.

Ramanski spektri oksidnih površina su dobijeni na micro-Raman TriVista 557 trodelnom spektrometru uz korišćenje linije na $514.5 \mathrm{~nm} \mathrm{Ar}^{+} / \mathrm{Kr}^{+}$jonskog lasera. Da bi se sprečilo pregrejavanje uzorka, korišćena je isključivo niska snaga lasera $(<10 \mathrm{~mW})$. 


\section{PLAZMA ELEKTROLITIČKA OKSIDACIJA ALUMINIJUMA}

Potreba za lakšim, trajnijim i mehanički otpornijim materijalima učinila je aluminijum i njegove legure odličnim kandidatima za primenu pre svega u avio i automobilskoj industriji, a potom i u ostalim industrijskim granama [109,123-125]. Ipak, pre bilo kakve primene, potrebno je pronaći načine da se poboljšaju slaba otpornost aluminijuma na habanje i koroziju, kao i njegova loša površinska mikro tvrdoća.

PEO oksidacija se pokazala kao efektivna i jeftina metoda koja za kratko vreme proizvodi modifikovane i poboljšane površine na aluminijumu [126,127,128]. U velikom broju radova pokazano je kvalitet na ovaj način dobijenih slojeva zavisi od gustine struje anodizacije, kao i od sastava i temperature elektrolita [79,85,129,130]. Pokazano je da veće gustine struje i niže temperature elektrolita favorizuju rast PEO sloja. Ma i saradnici [131] su utvrdili da se PEO slojevi nastali iz rastvora koji sadrži silicijum odlikuju dobrom otpornošću na habanje, dok oni formirani u rastvorima sa fosforom pokazuju odličnu otpornost na koroziju. Eksperimentalni podaci Gu-a [132] za PEO proces na aluminijumu u vodenom rastvoru $\mathrm{NaOH}$ su pokazali da su slojevi nastali u elektrolitima koji sadrže fosfor termički stabilniji.

U ovom poglavlju biće predstavljeni rezultati optičke karakterizacije i analize mikro pražnjenja u realnom vremenu, kao i rezultati analize morfologije i hemijskog i faznog sastava dobijenih oksidnih slojeva. [133]. Svi eksperimenti su izvršeni u vodenom rastvoru volframsilicijumske heteropolikiseline (WSiA).

\subsection{Eksperimentalni podaci}

Oksidne površine su formirane na uzorcima aluminijuma dimenzija: $25 \mathrm{~mm}$ x $5 \mathrm{~mm}$ x $0.25 \mathrm{~mm}$, čistoće 99.5\%. Pre same anodizacije, uzorci su u ultrazvučnoj kadi odmašćeni u acetonu, etanolu i destilovanoj vodi. Tako očišćeni uzorci, sušeni su u struji toplog vazduha i anodizirani u $0.001 \mathrm{M}$ vodenom rastvoru WSiA. Anodizacija je vršena u elektrolitičkoj ćeliji u režimu konstantne struje od $25 \mathrm{~mA} / \mathrm{cm}^{2}$. U toku anodizacije, temperatura elektrolita je održavana konstantnom $(19 \pm 1){ }^{\circ} \mathrm{C}$. 


\subsection{Optička karakterizacija i analiza PEO procesa na aluminijumu u realnom vremenu}

\subsubsection{Zavisnost napona i intenziteta luminescencije od vremena anodizacije}

Na SI. 4.1. data je tipična zavisnost napona anodizacije i intenziteta luminescencije u toku anodizacije aluminijuma u WSiA.

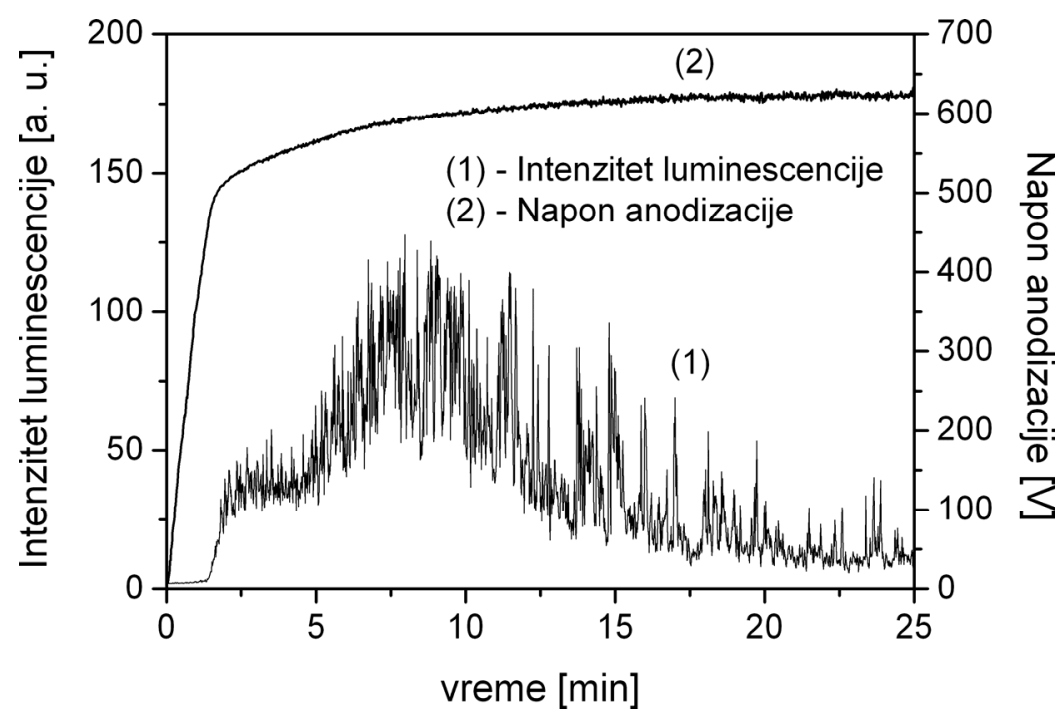

Slika 4.1. Zavisnost napona i intenziteta luminescencije od vremena anodizacije.

Na naponskoj krivi se jasno uočavaju tri etape PEO procesa. U skladu sa predloženim mehanizmom [31], na samom početku (prvih 70 s) PEO procesa na aluminijumu napon anodizacije linearno raste sa rastom barijernog oksidnog sloja. Dostizanjem kritičnog napona anodizacije, koji za date uslove anodizacije (gustinu struje od $25 \mathrm{~mA} / \mathrm{cm}^{2}$ i temperaturu elektrolita od $19{ }^{\circ} \mathrm{C}$ ) iznosi $\sim 500 \mathrm{~V}$, na površini uzorka se javljaju mikro pražnjenja, ravnomerno raspoređena po čitavoj površini, Sl. 4.2-a. Uniformni rast barijernog sloja prekida se dielektričnim probojem praćenim odstupanjem od linearnosti na krivoj zavisnosti napona od PEO vremena.

Ukupna gustina struje $\mathrm{u}$ toku anodizacije aluminijuma je suma komponenti jonske $\mathrm{i}$ elektronske gustine struje. U prvoj etapi procesa, jonska struja je za nekoliko redova veličine veća od elektronske komponente i da bi se jačina električnog polja održala konstantnom, napon anodizacije mora linearno da raste sa porastom debljine sloja (SI. 4.1). Kada lavina ubrzanih elektrona u provodnoj zoni dostigne svoju kritičnu vrednost, javlja se dielektrični proboj i naponska kriva odstupa od linearnosti. U ovoj etapi, potrebni su manji naponi da bi 
se ukupna gustina struje održala konstantnom. U završnim fazama procesa, doprinos elektronske struje ukupnoj gustini je daleko veći od jonske i nagib naponske krive dostiže skoro nultu vrednost.

Na Sl. 4.1 pokazana je i zavisnost intenziteta luminescencije od vremena anodizacije. Uniformni rast oksidnog sloja je praćen anodnom luminescencijom (galvanoluminescencija GL) [134] koja je posledica ekscitacije luminescentnih centara u neelastičnim sudarima sa elektronima elektronske lavine $\mathrm{u}$ jakom električnom polju $\left(10^{6}-10^{8} \mathrm{~V} / \mathrm{cm}\right)$. GL intenzitet raste kvazi-eksponencijalno sa naponom anodizacije, odnosno sa vremenom anodizacije. Postizanjem kritičnog napona anodizicije, na anodnu luminescenciju se superponira svetlosni intenzitet izazvan probojima i ukupan intenzitet luminescencije raste.

\subsubsection{Dinamika i distribucija mikro pražnjenja u toku PEO procesa}

Snimanje pojedinačih svetlosnih efekata (mikro pražnjenja) u realnom vremenu omogućava praćenje dinamike pojave i veličine mikro pražnjenja u toku PEO procesa na aluminijumu. Na Sl. 4.2 prikazana je pojava mikro pražnjenja u različitim etapama PEO procesa. Mikro pražnjenja se, u toku PEO procesa, generišu prilikom proboja na takozvanim "slabim mestima" na površini uzorka. Slaba mesta na površini uzorka mogu biti pukotine, nečistoće, oštre ivice i slično. Na tim mestima je otpor kretanju elektrona manji i struja pronalazi svoj put kroz oksidni sloj. Pošto se broj"slabih mesta" smanjuje sa rastom PEO sloja, prolaz iste gustine struje biva lokalizovan na preostalim mestima, uslovljavajući manji broj mikro pražnjenja u završnim etapama procesa i porast njihovih površina poprečnog preseka.

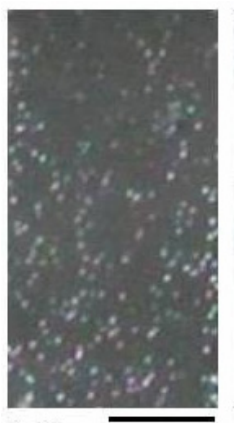

(a) $\overline{5 \mathrm{~mm}}$

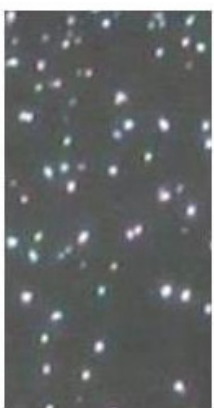

(b)

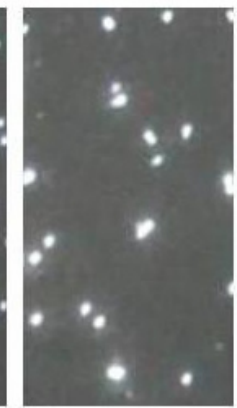

(c)

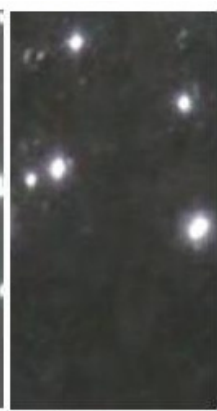

(d)

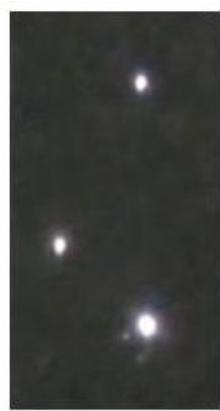

(e)

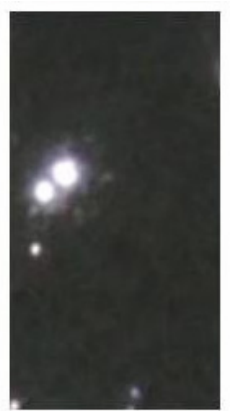

(f)

Slika 4.2. Pojava mikro pražnjenja u različitim etapama PEO procesa:

(a) $1.5 \mathrm{~min}$; (b) $3 \mathrm{~min}$; (c) $5 \mathrm{~min}$; (d) $15 \mathrm{~min}$; (e) $30 \mathrm{~min}$; (f) $60 \mathrm{~min}$. 
Na Sl. 4.3-a. pokazano je kako se menja prostorna gustina mikro pražnjenja (broj mikro pražnjenja po jedinici površine) u toku PEO procesa. Zavisnost procenta aktivne površine pražnjenja tj., procenat površine uzorka koji je u datom trenutku posmatranja izložen mikro pražnjenjima različitih veličina, u toku procesa na aluminijumu data je na SI. 4.3-b.

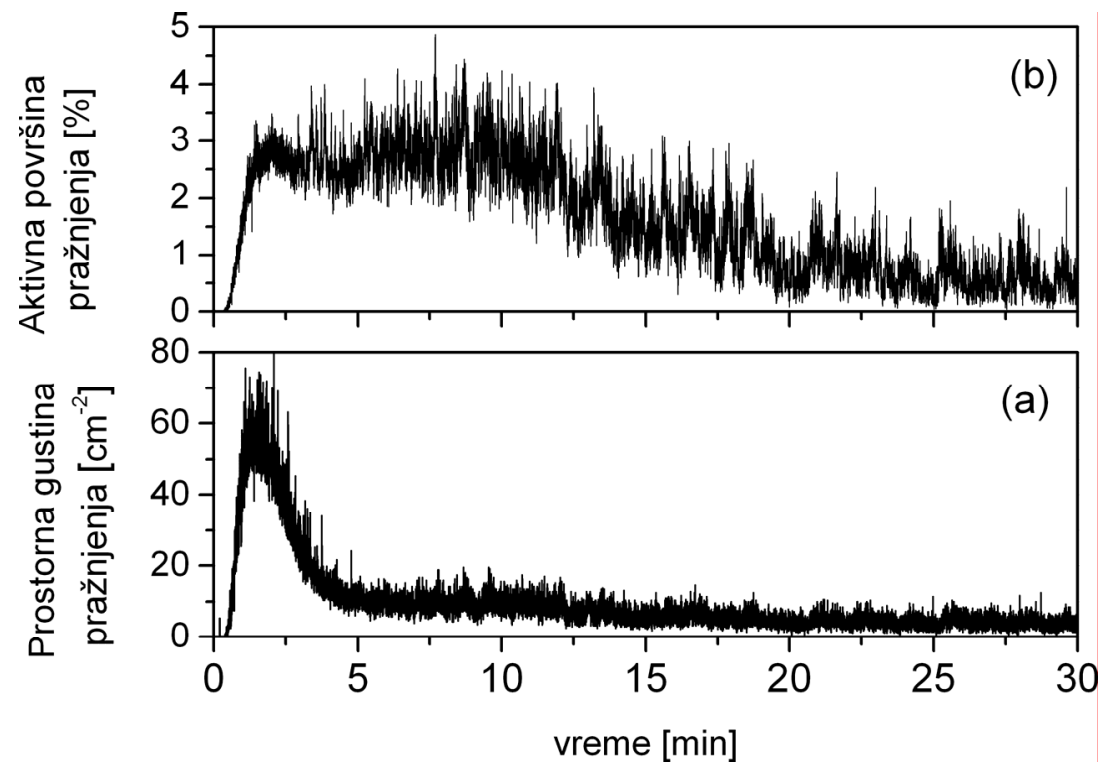

Slika 4.3. Karakteristike mikro pražnjenja u različitim etapama PEO procesa: (a) prostorna gustina mikro pražnjenja; (b) procenat okside površine istovremeno pokrivena aktivnim mestima za mikro pražnjenje.

Kao što se i može očekivati, najveća prostorna gustina mikro pražnjenja se javlja u prvim minutima procesa $\left(\sim 1.5 \mathrm{~min}\right.$ od početka) i iznosi $\sim 70 \mathrm{~cm}^{-2}$, a potom naglo pada na $\sim 10$ $\mathrm{cm}^{-2}$ i u narednih 10 min ostaje konstantna. Procenat aktivne površine istovremeno izložen događajima mikro pražnjenja takođe raste prvih 1.5 min PEO procesa i dostiže svoj maksimum od $2.5 \%$, a potom u narednih 10 minuta opada.

Na Sl. 4.4 je grafički prikazana dimenzionalna distribucija veličina mikro pražnjenja sa vremenom PEO. Prva, mala mikro pražnjenja su vidljiva $\sim 1.5 \min$ od početka anodizacije (Sl. 4.4-a). Relativno mala mikro pražnjenja, (površina poprečnog preseka $<0.2 \mathrm{~mm}^{2}$ ) prisutna su u svim fazama procesa, ali na samom početku PEO procesa njihova koncentracija u ukupnom broju je najveća i iznosi 92 \%. (Sl. 4.4-a). Kako proces napreduje, njihova koncentracija se smanjuje i $10 \mathrm{~min}$ od početka PEO procesa iznosi 48 \%. Velika mikro pražnjenja se mogu zapaziti u kasnijim fazama PEO procesa. 

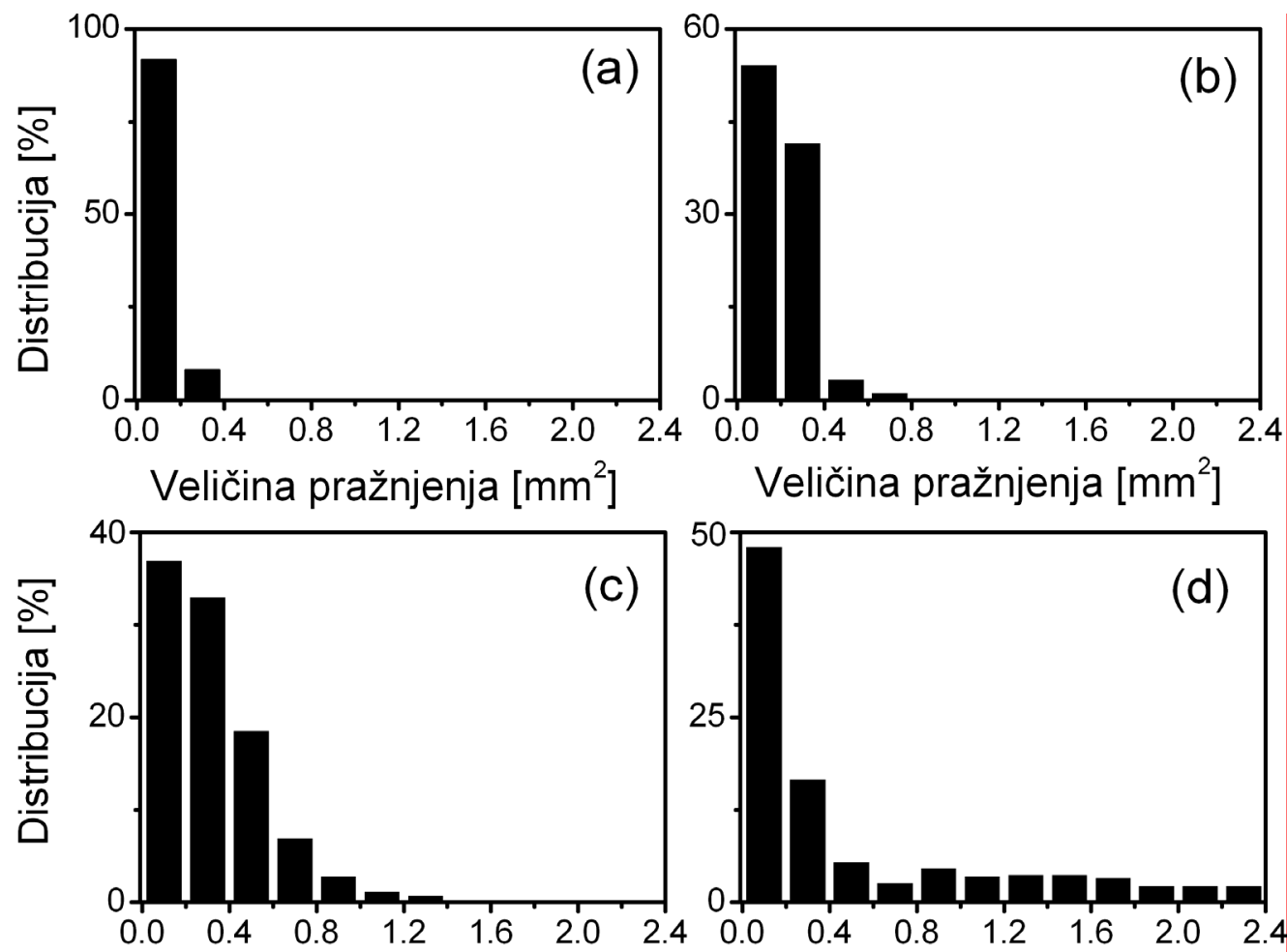

Veličina pražnjenja $\left[\mathrm{mm}^{2}\right]$

Veličina pražnjenja $\left[\mathrm{mm}^{2}\right] \quad$ Veličina pražnjenja $\left[\mathrm{mm}^{2}\right]$

Slika 4.4. Dimenzionalna distribucija veličine mikro pražnjenja u različitim fazama PEO procesa:

(a) $1.5 \mathrm{~min}$, (b) $3 \mathrm{~min}$, (c) $5 \mathrm{~min}$ i (d) $10 \mathrm{~min}$

\subsubsection{Spektralna karakterizacija PEO procesa}

Tipičan optičko emisioni spektar mikro pražnjenja na aluminijumu u toku PEO procesa u oblasti talasnih dužina od $380 \mathrm{~nm}$ do $850 \mathrm{~nm}$ dat je na SI. 4.5. Sve detektovane linije $\mathrm{u}$ spektrima pripadaju aluminijumu $\mathrm{i}$ jonskim $\mathrm{i}$ atomskim vrstama prisutnim $\mathrm{u}$ elektrolitu. Najintenzivnije linije u spektru pripadaju Balmerovoj seriji za vodoniik, $H_{\alpha}$ na $656.28 \mathrm{~nm} \mathrm{i} \mathrm{H}_{\beta}$ na $486.13 \mathrm{~nm}$. Najintezivnije linije na nižim talasnim dužinama (394.40 nm i $396.15 \mathrm{~nm}$ ) pripadaju atomskom aluminijumu. Jonske linije Al II su i triplet na $705.20 \mathrm{~nm}$, $705.67 \mathrm{~nm}$ i $706.38 \mathrm{~nm}$. Atomski kiseonik se u spektru javlja u vidu tripleta na $777.19 \mathrm{~nm}$, $777.42 \mathrm{~nm}$ i $777.54 \mathrm{~nm}$ i na $844.62 \mathrm{~nm}, 844.64 \mathrm{~nm}$ i $844.68 \mathrm{~nm}$. 


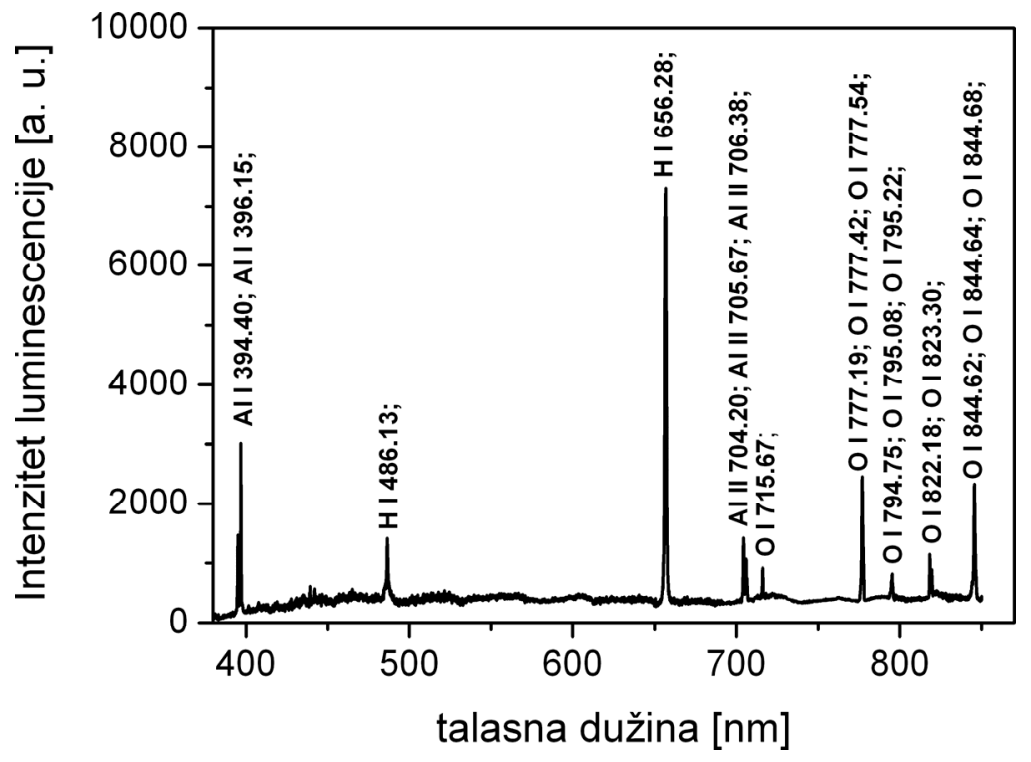

Slika 4.5. Optičko emisioni spektar dobijen u toku PEO procesa na aluminijumu u opsegu talasnih dužina od $380 \mathrm{~nm}$ do $850 \mathrm{~nm}$

Detaljan optičko emisioni spektar u oblasti talasnih dužina od $380 \mathrm{~nm}$ do $500 \mathrm{~nm}$ dat je na Sl. 4.6. Mnoge linije koje potiču od O II i W I, kao i jaka vibraciona traka AlO sistema na 484.2 nm lako se mogu uočiti.

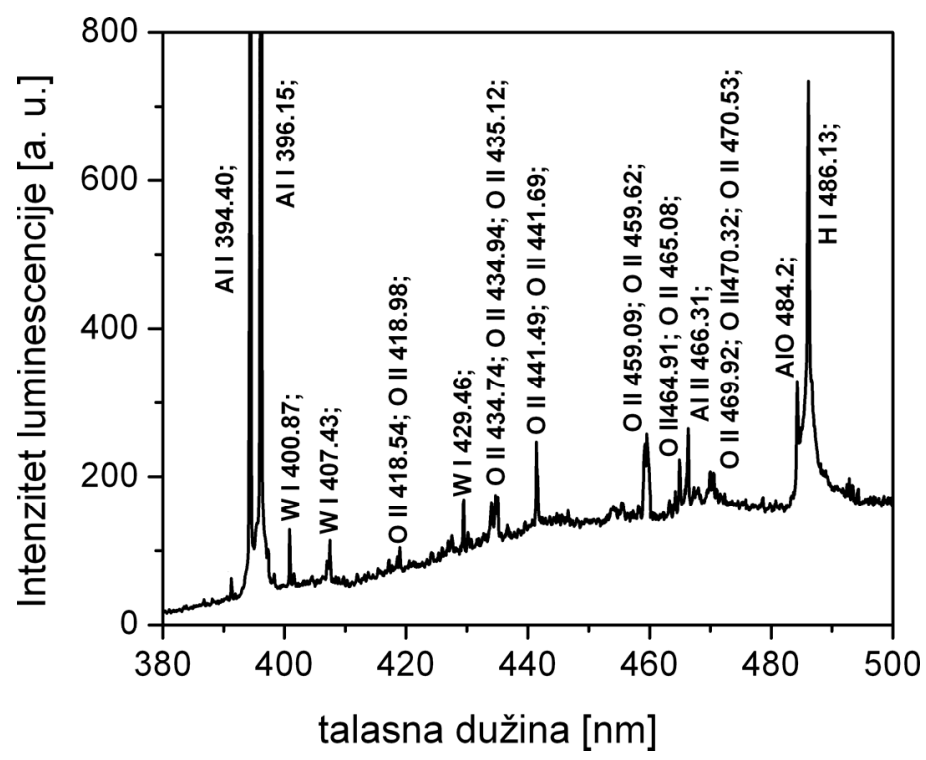

Slika 4.6. Optičko emisioni spektar dobijen u toku PEO procesa u opsegu talasnih dužina od $380 \mathrm{~nm}$ do $500 \mathrm{~nm}$. 


\subsection{Morfologija površina oksidnih slojeva}

Na Sl. 4.7 prikazani su AFM mikrografi površine oksidnih slojeva dobijenih u različitim etapama PEO procesa. Sa porastom vremena PEO procesa broj kanala za pražnjenje se smanjuje, dok njihov dijametar raste, što je u korelaciji sa rezultatima analize PEO procesa u realnom vremenu.
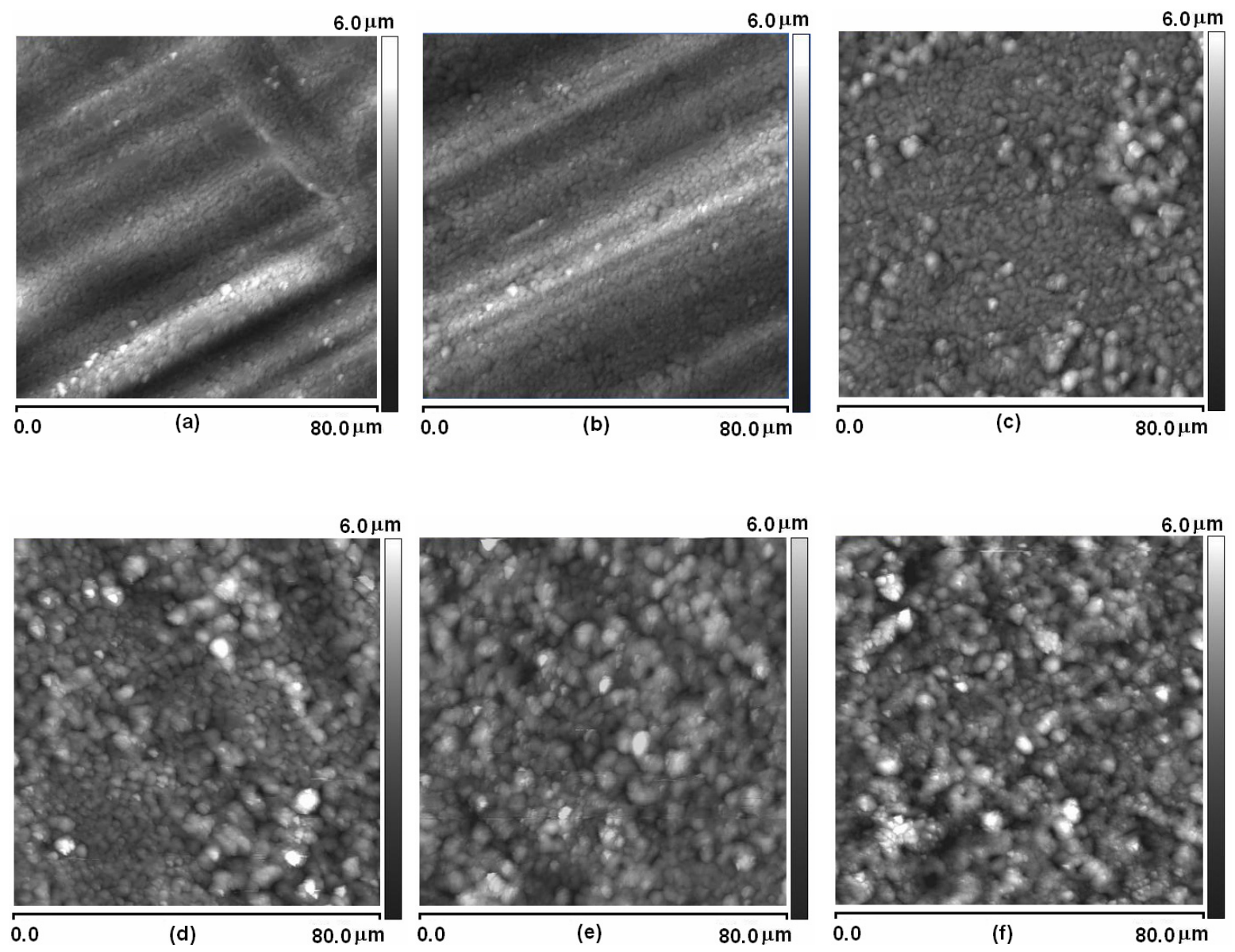

Slika 4.7. AFM slika površina PEO slojeva u različitim etapama PEO procesa:

(a) $3 \mathrm{~min}$; (b) $5 \mathrm{~min}$; (c) $10 \mathrm{~min}$; (d) $20 \mathrm{~min}$; (e) $30 \mathrm{~min}$; (f) $60 \mathrm{~min}$.

Detaljnom analizom na ovaj način dobijenih mikroskopskih slika se pokazuje da deblje oksidne površine imaju veću hrapavost (Sl. 4.8). U početnoj fazi PEO procesa kanali za mikro pražnjenja su ravnomerno distribuirani i oksidne površine imaju malu hrapavost. Kako se broj mikro kanala za pražnjenje smanjuje, a njihov dijametar raste, javljaju se neuniformnosti na površini oksidnog sloja, što dovodi do povećanja hrapavosti. 


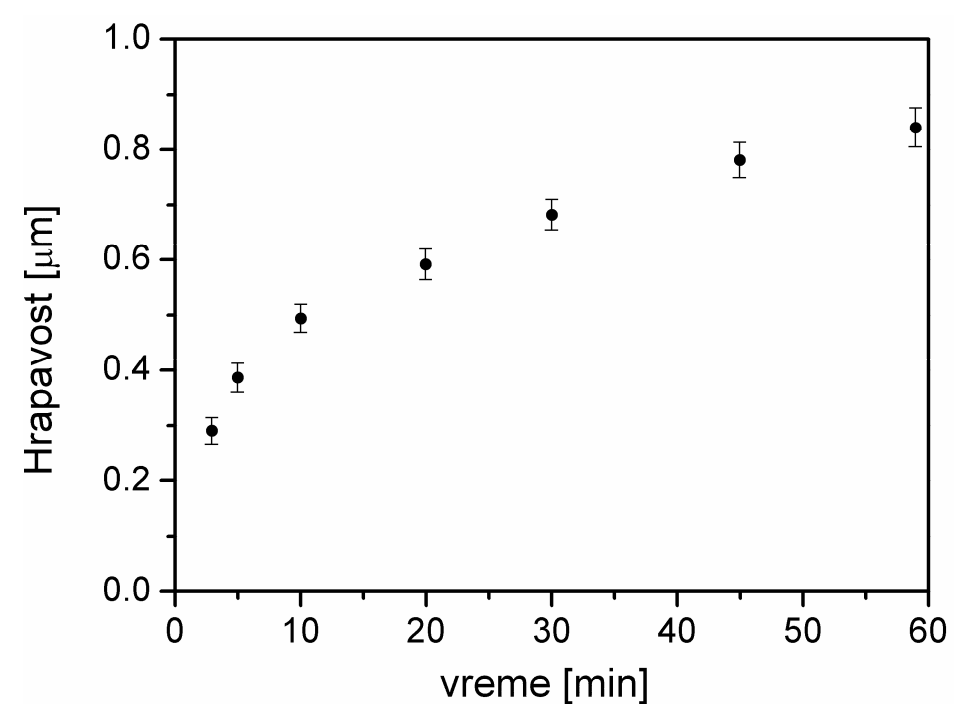

Slika 4.8. Uticaj vremena PEO procesa na hrapavost oksidnih površina.

\subsection{Hemijski i fazni sastav oksidnih slojeva}

Početak PEO procesa na aluminjumu u WSiA prati rast oksidnog sloja na granicama aluminijum-oksid i oksid-elektrolit. Ovaj rast je rezultat migracije $\mathrm{O}^{2-} / \mathrm{OH}^{-}$i $\mathrm{Al}^{3+}$ jona $\mathrm{kroz}$ oksidni sloj u prisustvu jakog električnog polja. Osnovne oksido-redukcione reakcije koje prati ovaj deo proces su :

$$
\begin{aligned}
& 2 \mathrm{Al}+3 \mathrm{O}^{2-}{ }_{\text {solid }} \rightarrow \mathrm{Al}_{2} \mathrm{O}_{3}+6 \mathrm{e}^{-}, \\
& \mathrm{Al} \rightarrow \mathrm{Al}^{3+}{ }_{\text {solid }}+3 \mathrm{e}^{-} .
\end{aligned}
$$

$\mathrm{Na}$ granici oksid-elektrolit, $\mathrm{Al}^{3+}$ joni reaguju sa molekulima vode prema reakciji:

$$
2 \mathrm{Al}^{3+}{ }_{\text {solid }}+9 \mathrm{H}_{2} \mathrm{O} \rightarrow \mathrm{Al}_{2} \mathrm{O}_{3}+6 \mathrm{H}_{3} \mathrm{O}^{+}
$$

Istovremeno sa rastom oksidnog sloja, anjonske komponente elektrolita, privučene jakim električnim poljem, dospevaju u kanale za pražnjenje, a katjonske vrste izbačene su u elektrolit. Izbačeni oksidovani aluminijum uvećava debljinu oksidnog sloja u samoj okolini kanala stvarajući karakteristične kraterske strukture na površini (Sl. 4.7).

U kanalima za pražnjenje se odvija i termalni prelaz molekula heteropolikiselina prema reakciji: 


$$
\mathrm{H}_{4} \mathrm{SiW}_{12} \mathrm{O}_{40} \rightarrow \mathrm{SiO}_{2}+12 \mathrm{WO}_{3}+2 \mathrm{H}_{2} \mathrm{O},
$$

a potom i dalja oksido-redukcija $\mathrm{WO}_{3}$ oksida sa prisutnim aluminijumom:

$$
\mathrm{WO}_{3}+2 \mathrm{Al} \rightarrow \mathrm{Al}_{2} \mathrm{O}_{3}+\mathrm{W} .
$$

SEM slika oksidne površine formirane PEO procesom posle 10 minuta prikazana je na Sl. 4.9. EDS spektri su snimljeni na dva različita mesta oksidne površine: u kanalu za pražnjenje (spectrum 1) i u okolini kanala za pražnjenje (spectrum 2). EDS analiza pokazuje da su glavni elementi detektovani na površini aluminijum, kiseonik i volfram. Sadržaj aluminijuma i volframa je mnogo veći u kanalima za pražnjenje (spectrum 1) nego u okolini kanala (spectrum 2), što potvrđuje mehanizam rasta sloja opisan na početku ovog paragrafa.

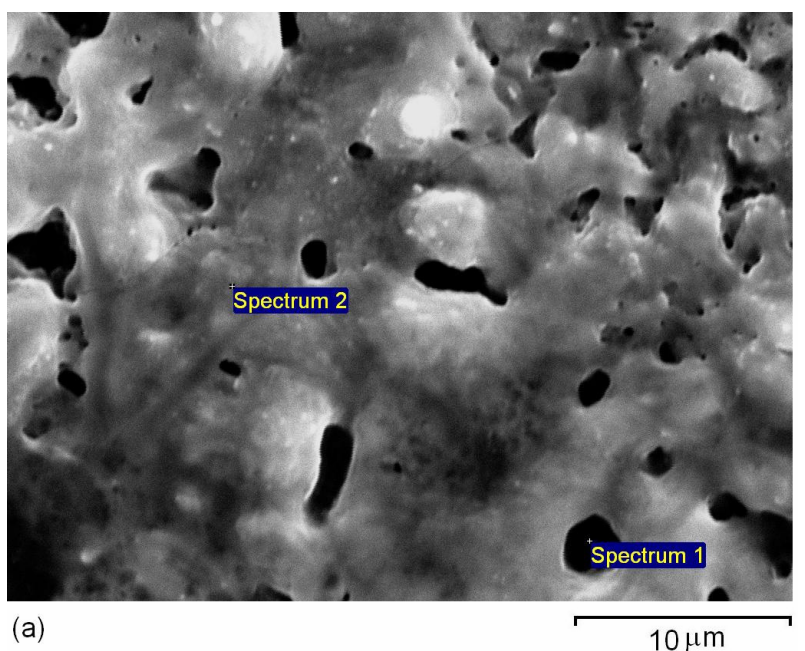

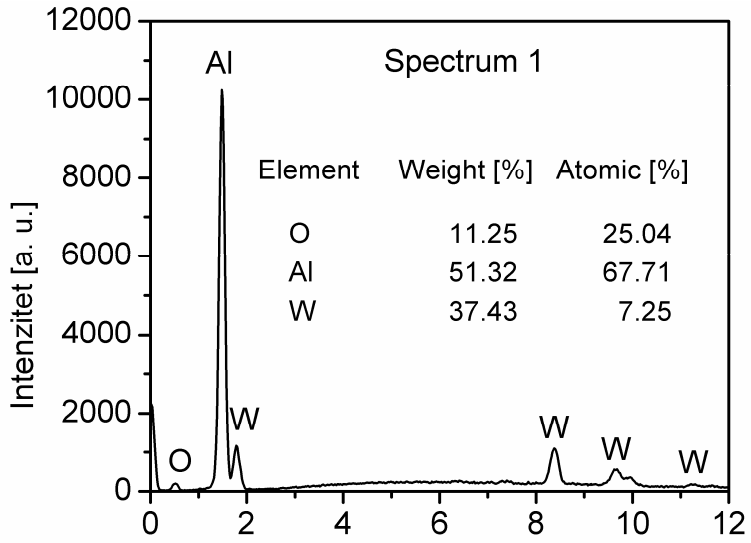

(b)

$$
\text { Energija [keV] }
$$

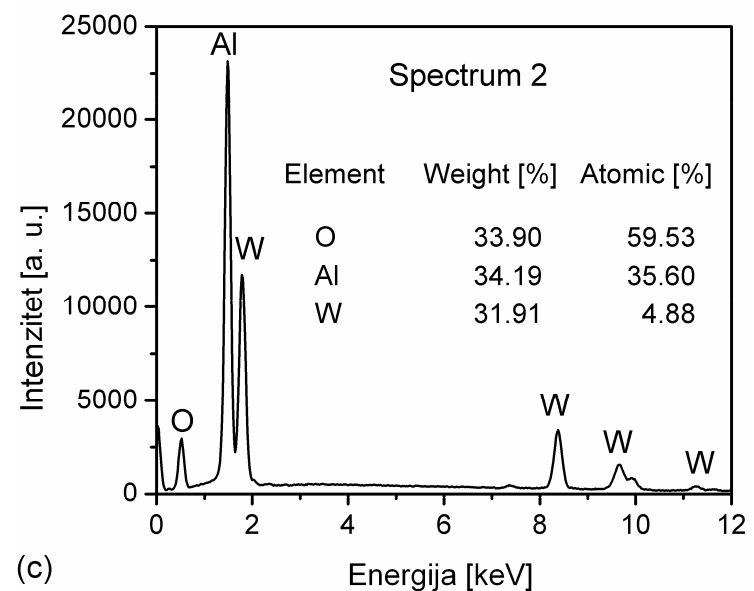

(c)

Slika 4.9. (a) SEM slika oksidne površine dobijene PEO procesom posle $10 \mathrm{~min}$; (b) EDS spektar snimljen u kanalu za pražnjenje; (c) EDS spektar snimljen u okolini kanala za pražnjenje. 
SEM slike poprečnog preseka oksidnih slojeva dobijenih u različitim etapama PEO procesa prikazane su na SI. 4.10. Jasno se uočavaju dva razdvojena regiona: tanji, barijerni sloj uz samu površinu metala i spoljni porozni sloj. Debljina spoljašnjeg sloja zavisi od dužine PEO tretmana. Rezultati EDS analize sastava PEO sloja, za dva uzorka na tri različite dubine prikazani su u Tabeli 1.1.

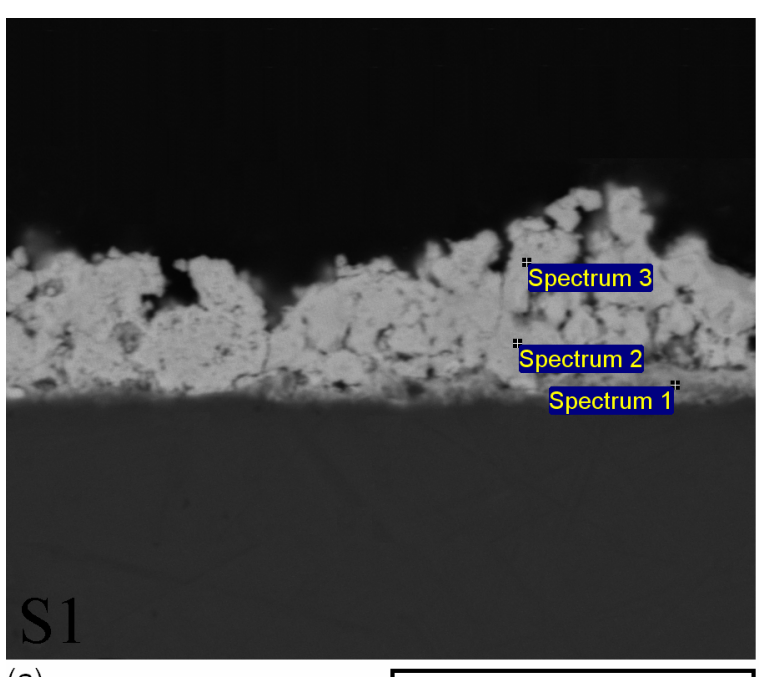

(a)

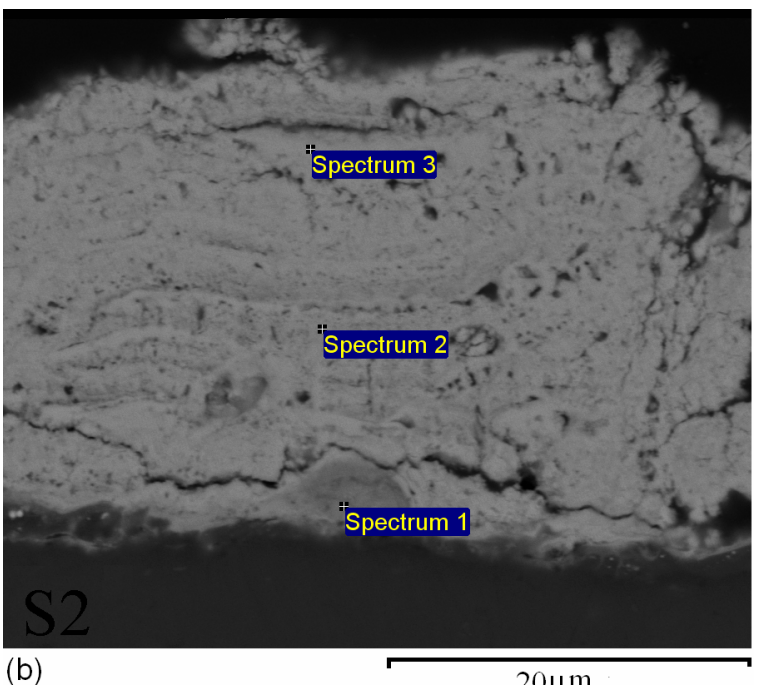

$20 \mu \mathrm{m}$

Slika 4.10. SEM slike poprečnih preseka površina uzorka aluminijuma u različitim etapama PEO procesa: (a) $20 \mathrm{~min}$; (b) $45 \mathrm{~min}$.

Tabela 4.1. EDS analiza sastava slojeva sa SI. 4.10.

\begin{tabular}{c|lccc}
\hline \multirow{2}{*}{ Uzorak } & \multicolumn{4}{|c}{ Atomska težina (\%) } \\
\hline \multirow{4}{*}{ S1 } & O & Al & W \\
\hline & Spectrum 1 & 66.66 & 27.73 & 5.61 \\
& Spectrum 2 & 77.23 & 1.12 & 21.65 \\
& Spectrum 3 & 78.87 & 1.38 & 19.76 \\
\hline \multirow{3}{*}{ S2 } & Spectrum 1 & 69.08 & 20.90 & 10.02 \\
& Spectrum 2 & 76.83 & 0.16 & 23.01 \\
& Spectrum 3 & 75.47 & 0.56 & 23.98 \\
\hline
\end{tabular}


Očekivano, sadržaj aluminijuma je najveći u unutrašnjem, barijernom sloju. Nasuprot tome, sadržaj W raste kako se udaljavamo od granice aluminijum-oksidni sloj, sugerišući da se volframski oksidi formiraju upravo u spoljašnjem PEO sloju, na granici PEO slojelektrolit. Sadržaj kiseonika se može smatrati konstantnim u poređenju sa Al i W.

XRD spektri za četiri oksidne površine formirane PEO procesom u toku različitog vremena prikazani su na Sl. 4.11. Oksidne površine su delimično kristalizovane i uglavnom se sastoje od $\gamma-\mathrm{Al}_{2} \mathrm{O}_{3} \mathrm{i} \mathrm{WO}_{3}$. Elementarni aluminijum uglavnom potiče od substrata i zato su difrakcione linije aluminijuma toliko jake.

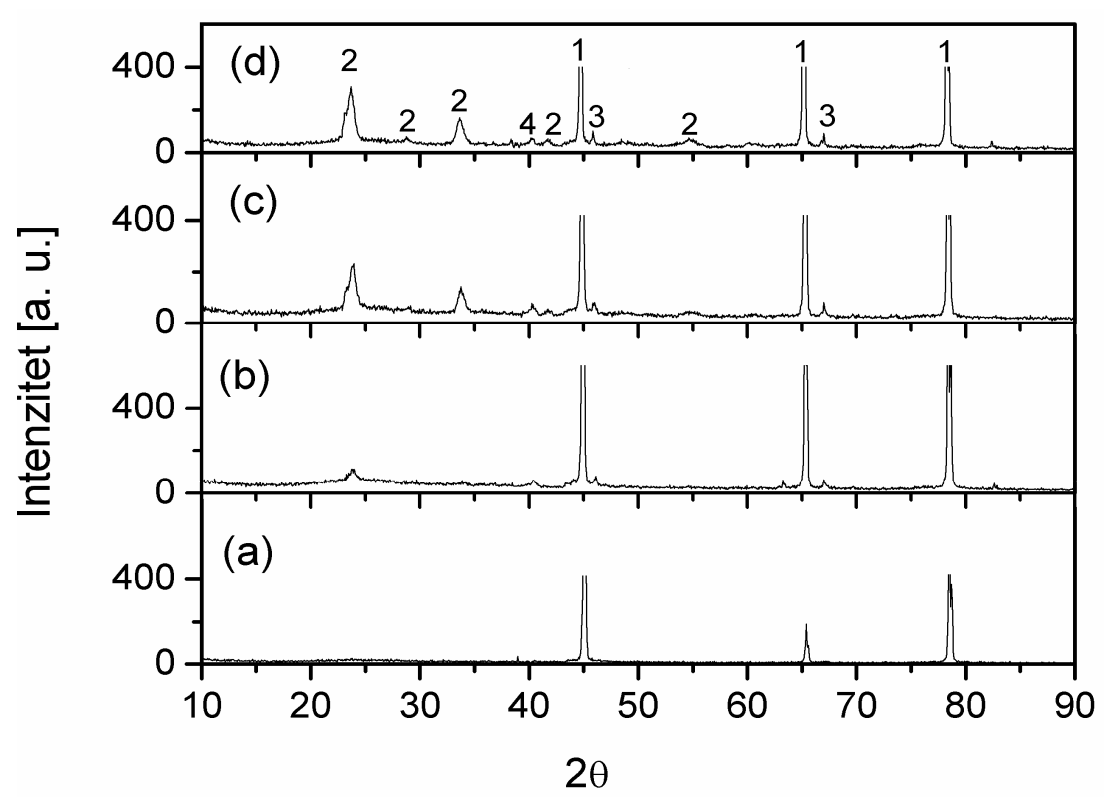

Slika 4.11. XRD spektri oksidnih slojeva u različitim etapama PEO procesa:

(a) $5 \mathrm{~min}$; (b) $10 \mathrm{~min}$; (c) $20 \mathrm{~min}$; (d) $30 \mathrm{~min}$. Difrakcione linije: (1) $\mathrm{Al}$; (2) $\mathrm{WO}_{3}$; (3) $\gamma-\mathrm{Al}_{2} \mathrm{O}_{3}$; (4) W.

Ramanovi spektri dobijenih oksidnih slojeva na aluminijumu daju uvid u formiranje kovalentnih veza i potvrdu da su se u procesu anodizacije zaista formirale volframske bronze. Na Sl. 4.12-a dat je referentni Ramanov spektar WSiA izložene termalnom tretmanu na $550{ }^{\circ} \mathrm{C}$, dok Ramanovi spektri na Sl. 4.12-b i Sl. 4.12-c odgovaraju oksidnim slojevima nastalim nakon $5 \mathrm{~min}$ i $30 \mathrm{~min}$ PEO procesa, respektivno. U slučaju oba spektra uzorka evidento je prisustvo WO vibracionih traka na $801 \mathrm{~cm}^{-1}, 685 \mathrm{~cm}^{-1}, 268 \mathrm{~cm}^{-1} \mathrm{i} 108 \mathrm{~cm}^{-1}$. 


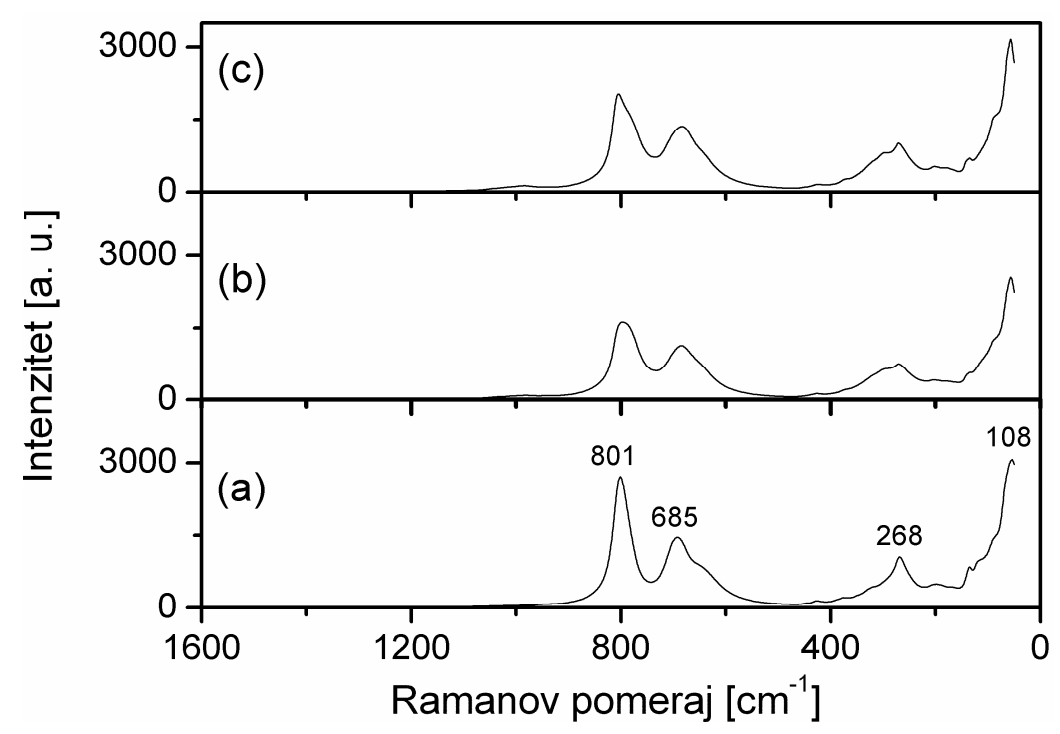

Slika 4.12. Ramanovi spektri: (a) referentni spektar uzorka WSiA nakon termalnog tretmana na $550{ }^{\circ} \mathrm{C}$;

(b) spektar oksidnog sloja dobijen nakon 5 min PEO tretmana;

(c) spektar oksidnog sloja dobijen nakon 30 min PEO tretmana.

Sličnost referentnog Ramanovog spektra i Ramanovih spektara oksidnih slojeva na aluminijumu ukazuje i na njihov sličan sastav. Krajnji zaključak je da su se u PEO procesu formirale odgovarajuće bronze tipa $\mathrm{ReO}_{3}$ sa karakterističnim istežućim vibracionim trakama (W-O-W) na $805 \mathrm{~cm}^{-1}$ i $706 \mathrm{~cm}^{-1}$ i savijajućom trakom na $273 \mathrm{~cm}^{-1}$ [13]. Vibraciona traka na $1000 \mathrm{~cm}^{-1}$ pripisuje se istežućim vibracijama Si-O sistema [32]. 


\section{PLAZMA ELEKTROLITIČKA OKSIDACIJA TITANIJUMA}

Zahvaljujući dobrim mehaničkim osobinama, hemijskoj stabilnosti, visokoj tački topljenja i prilično dobroj biokompatibilnosti, titanijum i njegove legure pronalaze sve veću primenu u avio industriji [135,136], automobilskoj industriji [137], industriji implantata [5,138-140], energetici [141] i vojnoj industriji [142].

Sa druge strane, titanijum i njegove legure pokazuju niz nedostataka u smislu korozivnosti i triboloških osobina. Jedan od načina da se te osobine poboljšaju jeste stvaranje zaštitnih slojeva nekom od dostupnih metoda [143,144]. Neke od tehnika koje se koriste u cilju dobijanja modifikovanih slojeva na titanijumu su: površinska oksidacija [145], elektrohemijski tretman [146], sol-gel metod [147,148], hidrotermalni tretman [149], kombinacija hidrotermalog i elektrohemijskog tretmana [150,151] i plazma-sprej metoda [152]. Većina njih zahteva skupe aparature, dosta vremena ili visoko temperaturne procese čija je primena ograničena termalnom stabilnošću samih slojeva. PEO tehnika izlazi na kraj sa svim ovim nedostacima.

Yerokhin i saradnici su među prvima primenili PEO u cilju dobijanja slojeva željenih osobina na čistom Ti, ali i njegovoj leguri Ti-6Al-4V [14,153]. Svoj doprnos istraživanju PEO procesa i morfologije slojeva na titanijumu daje i grupa istraživača predvođena Xue-om [154]. Oni su ujedno pokazali da se korišćenjem asimetričnog AC izvora napona dobijaju intenzivnija mikro pražnjenja na površini, da dolazi do delimičnog rastvaranja oksida u negativnom poluciklusu i formiranja rutil faze. Rutil faza pokazuje jedan od najvećih indeksa refrakcije.

Han i saradnici su pokazali da električni parametri i sastav elektrolita igraju značajnu ulogu u PEO procesima na titanijumu [155]. Ispitivali su slojeve dobijene u 4 različita elektrolita i otkrili da morfologija i njihov sastav u potpunosti zavise od izbora elektrolita $i$ primenjenog napona.

Pogodnim izborom parametara PEO procesa na titanijumu, mogu se poboljšati njegova otpornost na koroziju i habanje. Biokompatibilnost titatnijuma se može poboljšati različitim elektrohemijskim tretmanima u elektrolitima koji sadrže kalcijum i fosfor kakvi su: trikalcijum fosfat ili hidroksiapatiti [156-158]. Materijali koji na taj način nastaju imaju sličan hemijski sastav kao i kosti. 
U ovom istraživanju opredelili smo se da ispitujemo morfologiju i sastav slojeva nastalih u toku PEO procesa na titanijumu u elektrolitima koji sadrže volfram. Oksidni slojevi koji sadrže volfram imaju odlične katalitičke i poluprovodničke osobine [159] i izuzetnu otpornost na koroziju [160-163].

U ovom poglavlju dati su rezultati PEO procesa na titanijumu u dve heteropoli kiseline 12-volframsilicijumova kiselina (WSiA) i 12-volframfosforna kiselina (WPA) [164]. Obe imaju niskotemperaturne fazne prelaze (ispod $\left.600{ }^{\circ} \mathrm{C}\right)[165,166]$ i očekivano je da će se u uslovima visokih temperatura koje prate pražnjenja generisati volframovi oksidi. Optički emisioni spektri i podaci iz video analiza u realnom vremenu PEO procesa na titanijumu za dve korišćene heteropolikiseline $\left(\mathrm{H}_{4} \mathrm{SiW}_{12} \mathrm{O}_{40}\right.$ i $\left.\mathrm{H}_{3} \mathrm{PW}_{12} \mathrm{O}_{46} 6 \mathrm{H}_{2} \mathrm{O}\right)$ ne pokazuju bitnije razlike.

\subsection{Eksperimentalni podaci}

Oksidne površine su formirane na uzorcima titanijuma dimenzija $25 \mathrm{~mm}$ x $5 \mathrm{~mm}$ x $0.25 \mathrm{~mm}$ i čistoće $99.5 \%$. Pre postupka anodizacije uzorci su odmašćeni u ultrazvučnoj kadi u acetonu, etanolu i destilovanoj vodi. Tako očišćeni uzorci, sušeni su u struji toplog vazduha i anodizirani u $0.001 \mathrm{M}$ vodenom rastvoru WSiA i $0.001 \mathrm{M}$ vodenom rastvoru WPA. Anodizacija titanijuma je vršena u elektrolitičkoj ćeliji u režimu konstantne gustine struje od $150 \mathrm{~mA} / \mathrm{cm}^{2}$. U toku anodizacije, temperatura elektrolita je održavana konstantnom $(21 \pm 1)^{\circ} \mathrm{C}$.

\subsection{Optička karakterizacija i analiza PEO procesa na titanijumu u realnom vremenu}

\subsubsection{Zavisnost napona $i$ intenziteta luminescencije od vremena anodizacije}

$\mathrm{Za}$ razliku od ostalih ventilnih metala, PEO procesi na titanijumu u različitim elektrolitima ne pokazuju reproducibilnost kada je u pitanju napon proboja. U jednom broju slučajeva, proboj nije praćen pojavom mikro pražnjenja već samo oslobađanjem kiseonika [35-37]. To nije slučaj ako se kao elektrolit koriste heteropoli kiseline WSiA i WPA, pa smo se u ovom slučaju odlučili za njihovo korišćenje.

Na Sl. 5.1 pokazano je kako se napon anodizacije i intenzitet luminescencije menjaju sa vremenom u slučaju anodizacije titanijuma u WSiA. U početnoj fazi PEO procesa, rast 
oksidnog sloja, pri konstantnoj gustini struje, je praćen malim oscilacijama u naponskoj krivi. Poreklo tih oscilacija još uvek nije objašnjeno. U ovoj fazi procesa, za razliku od aluminijuma [19,167] i magnezijuma [168], titanijum ne pokazuje fenomen galvanoluminescencije.

Kada napon anodizacije dostigne vrednost od $420 \mathrm{~V}$, na površini uzorka pojavljuju se prva mikro pražnjenja. Početak proboja je praćen smanjenjem nagiba naponske krive i naglim povećanjem intenziteta luminescencije (SI. 5.1).

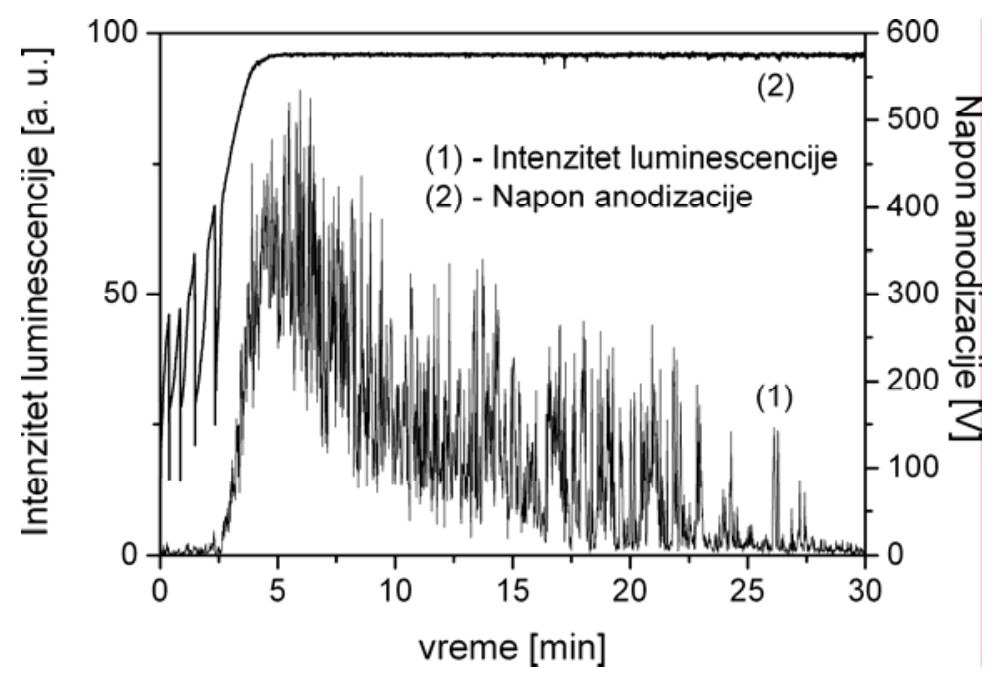

Slika 5.1. Zavisnost napona i intenziteta luminescencije od vremena anodizacije.

\subsubsection{Dinamika i distribucija mikro pražnjenja u toku PEO procesa}

Kao i u slučaju PEO procesa na aluminijumu, u dinamici pojave mikro pražnjenja na površini titanijuma izdvaja se nekoliko različitih etapa. Na samom početku anodizacije, zapažaju se uglavnom mala mikro pražnjenja sa prosečnim poprečnim presekom $\sim 0.025 \mathrm{~mm}^{2}$ (SI. 5.2-a.). Kako PEO proces napreduje tako i veličina mikro pražnjenja raste, dok se istovremeno njihov broj smanjuje (Sl. 5.2 b-d).

Površinska gustina mikro pražnjenja je maksimalna $\sim 1$ min od početka PEO procesa da bi se u narednih 2 min smanjila sa $250 \mathrm{~cm}^{-2}$ na $30 \mathrm{~cm}^{-2}$ (SI. 5.3-a). U isto vreme i procenat oksidne povšine prekriven aktivnim mestima za mikro pražnjenja dostiže svoj maksimum ( $\sim \%$ ) a potom monotono opada (Sl. 5.3-b.) 


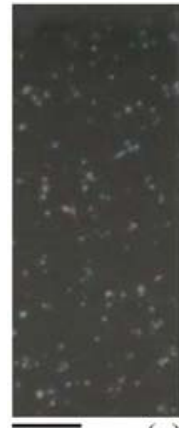

$\overline{2 \mathrm{~mm}}$

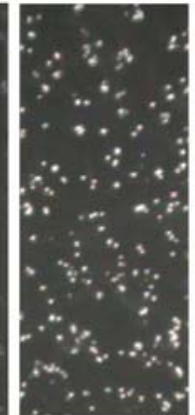

(b)

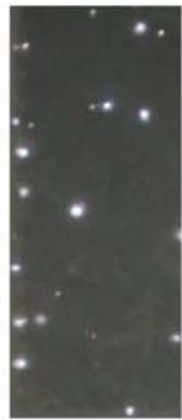

(c)

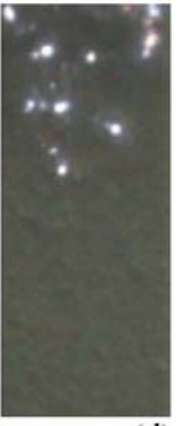

(d)

Slika 5.2. Pojava mikro pražnjenja u različitim etapama PEO procesa: (a) 10s; (b) 1 min; (c) 5 min; (d) 30 min.
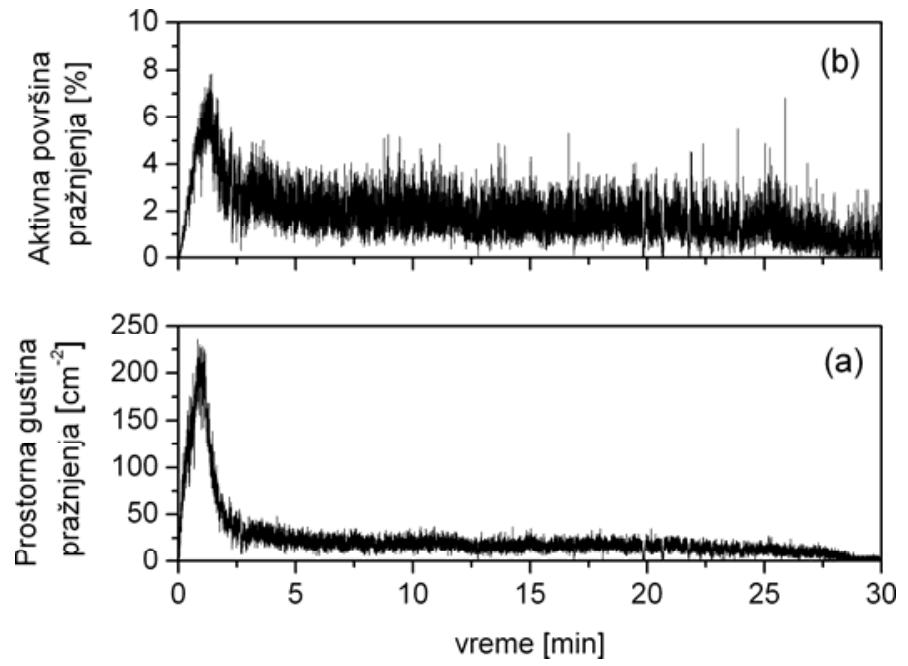

Slika 5.3. Karakteristike mikro pražnjenja u različitim etapama PEO procesa: (a) prostorna gustina mikro pražnjenja; (b) procenat okside površine istovremeno pokrivena aktivnim mestima za mikro pražnjenje.

Dimenzionalna distribucija mikro pražnjenja (SI. 5.4) daje detaljniji uvid $u$ procentualnu zastupljenost njihovih dimenzija u toku procesa. Koncentracija malih mikro pražnjenja (površina poprečnog preseka $<0.1 \mathrm{~mm}^{2}$ ) na samom početku procesa je skoro $100 \%$ (Sl. 5.4-a), da bi se postepeno smanjivala i u završnim fazama dostigla vrednost od oko $32 \%$ (SI. 5.4-d).

Za razliku od malih mikro pražnjenja koja su prisutna u toku celog PEO procesa, procenat srednjih mikro pražnjenja (površina poprečnog preseka u rasponu od $0.1 \mathrm{~mm}^{2}$ do $0.3 \mathrm{~mm}^{2}$ ) je zanemarljiv na samom početku, ali se postepeno povećava i dostiže svoj maksimum $(\sim 50 \%) \sim 5$ min nakon početka PEO procesa. Velika mikro pražnjenja (površina poprečnog preseka $>0.3 \mathrm{~mm}^{2}$ ) primećuju se tek u završnim fazama anodizacije . 

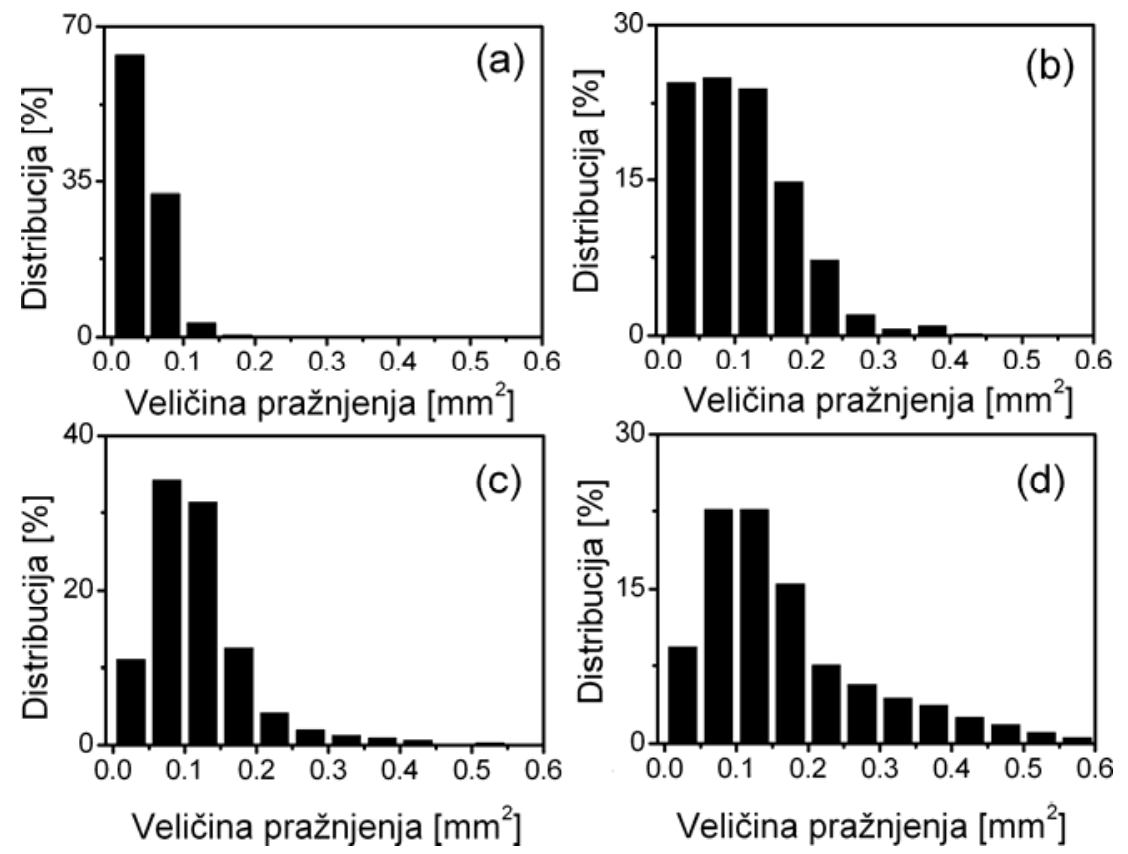

Slika 5.4. Dimenziona distribucija mikro pražnjenja u različitim etapama PEO procesa u WSiA:

(a) $1 \mathrm{~min}$; (b) $5 \mathrm{~min}$; (c) $15 \mathrm{~min}$; (d) $30 \mathrm{~min}$.

\subsubsection{Spektralna karakterizacija PEO procesa}

Tipični optičko emisioni spektar mikro pražnjenja na titanijumu u toku PEO procesa u oblasti talasnih dužine od $380 \mathrm{~nm}$ do $860 \mathrm{~nm}$ dat je na Sl. 5.5.

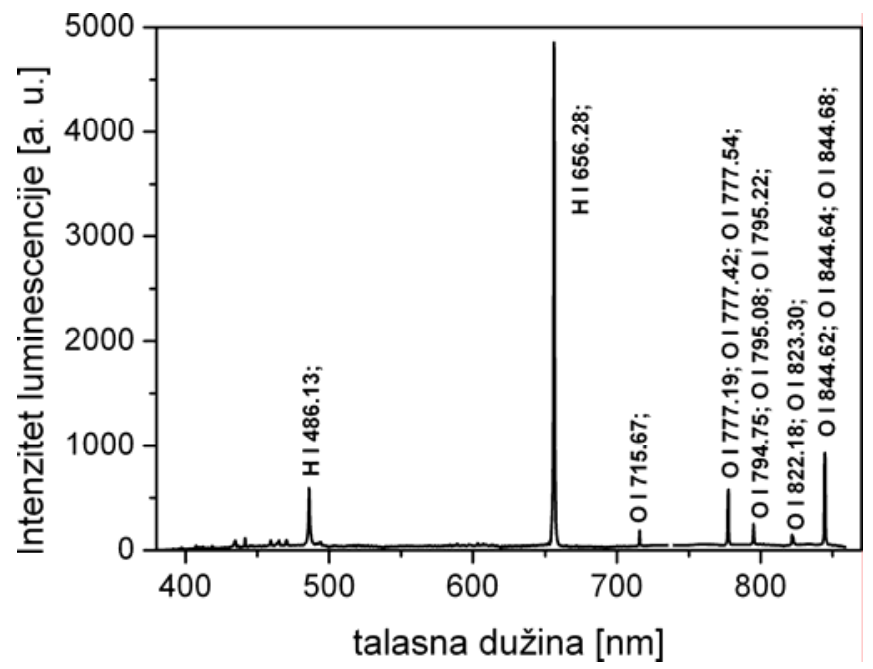

Slika 5.5. Optičko emisioni spektar dobijen u toku PEO procesa u opsegu talasnih dužina od $380 \mathrm{~nm}$ do $860 \mathrm{~nm}$. 

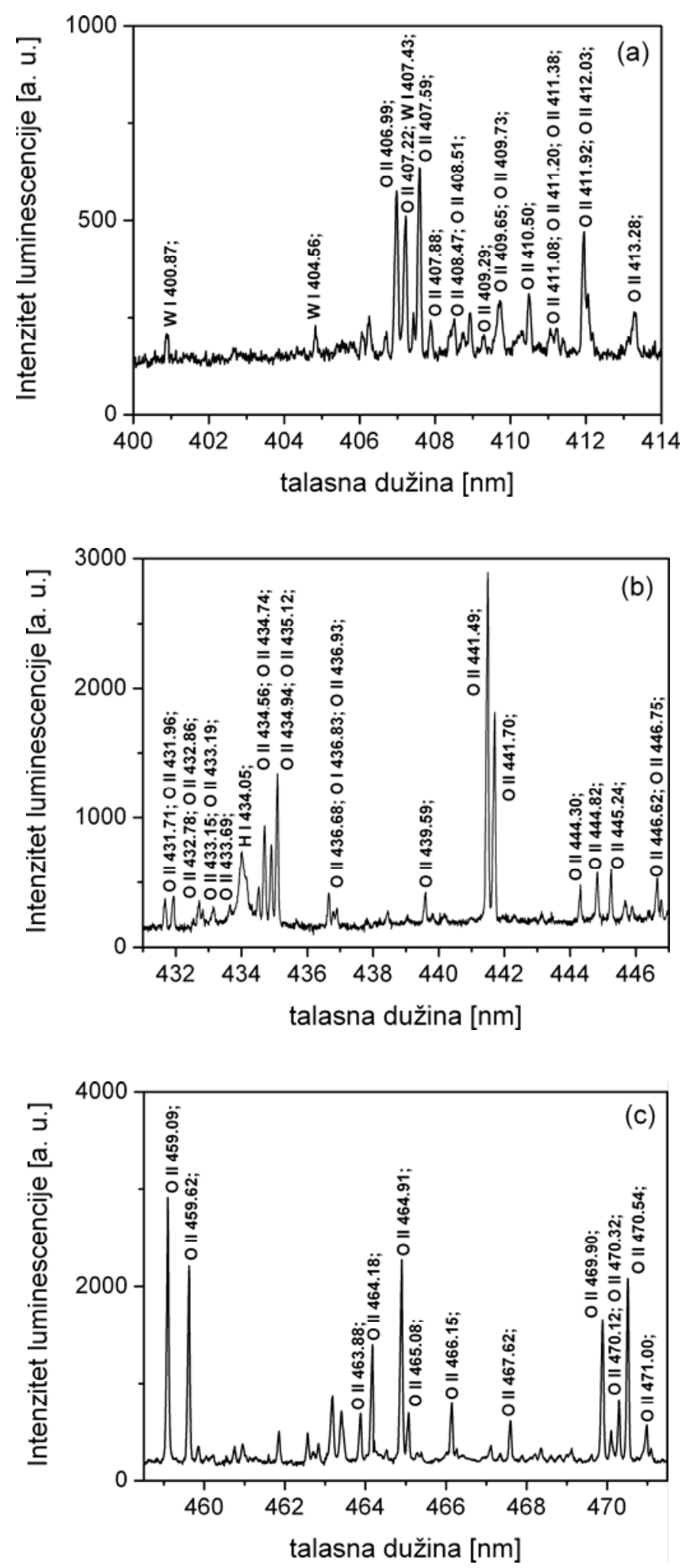

Slika 5.6. Optičko emisioni spektar visoke rezolucije u toku PEO procesa u opsegu talasnih dužina:

(a) $400 \mathrm{~nm}-414 \mathrm{~nm}$; (b) $431-447 \mathrm{~nm}$; (c) $459.5 \mathrm{~nm}-471.5 \mathrm{~nm}$ 
Identifikacija atomskih i jonskih linija ostvarena je preko NIST-ove spektralne baze podataka. Najizražajnije linije koje se zapažaju u spektru, pripadaju vodoniku i Balmerovoj seriji: $\mathrm{H}_{\alpha}(656.28 \mathrm{~nm})$ i $\mathrm{H}_{\beta}(486.13 \mathrm{~nm})$. Pored njih, prisutan je i triplet linija kiseonika O I na: $844.62 \mathrm{~nm}, 844.64 \mathrm{~nm}, 844.68 \mathrm{~nm}$ i O I linije na $777.19 \mathrm{~nm}, 777.42 \mathrm{~nm}, 777.54 \mathrm{~nm}$. Detektovane su i linije O I na $715.67 \mathrm{~nm}, 822.18 \mathrm{~nm}$ i $823.30 \mathrm{~nm}$. Linije titanijuma nisu zapažene u spektru.

U cilju identifikacije slabih linija na nižim talasnim dužinama, kao i za analizu oblika spektralnih linija, korišćen je spektrometar visoke rezolucije. Relevantni spektralni regioni su prikazani na SI. 5.6. Upotrebom spektrofotometra visoke rezolucije omogućena je detekcija jonskih linija kiseonika O II, linija volframa W I, kao i Balmerove linije vodonika $\mathrm{H}_{\gamma}$ $(434.05 \mathrm{~nm})$

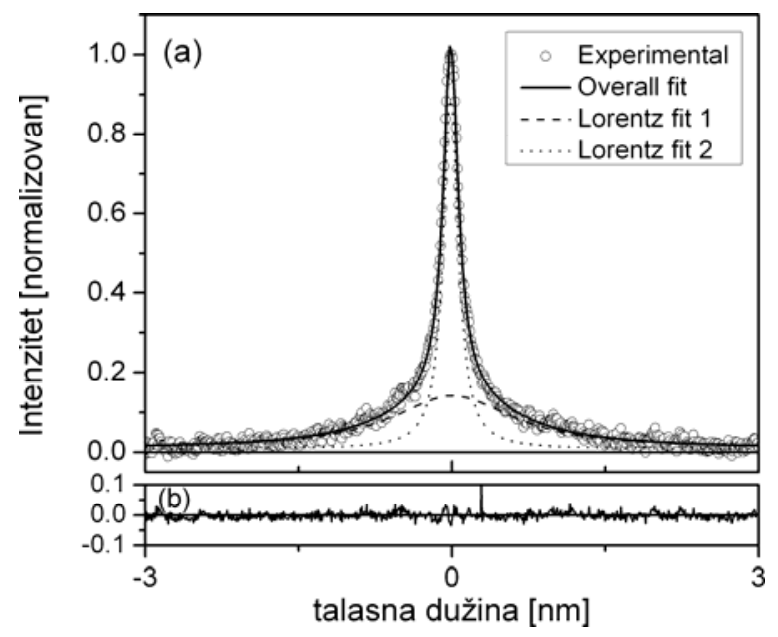

Slika 5.7. (a) Eksperimentalni profil $\mathrm{H}_{\beta}$ linije, fitovan sa dva Lorentz-ova profila; (b) grafik razlike fita $i$ eksperimentalnih rezultata

Za merenje elektronskih koncentracija korišćena je Balmerova linija $\mathrm{H}_{\beta}$. Balmerova linija $H_{\alpha}$ je veoma jaka u toku PEO procesa (SI. 5.5) i jako samoapsorbovana. Iz tog razloga $\mathrm{H}_{\alpha}$ linija nije pogodna za pouzdanu analizu oblika spektralnih linija. Slaba Balmerova linija $\mathrm{H}_{\gamma}$ u PEO procesu interferira sa O II linijama (SI. 5.6-b) i takođe nije pouzdana za analizu. Oblik $\mathrm{H}_{\beta}$ linije se može pouzdano fitovati samo sa dva Lorencova profila (Sl. 5.7). Poluširina linije na polovini maksimuma, za viši gornji profil $\mathrm{H}_{\beta}$ linije, je $\sim 0.18 \mathrm{~nm}$, dok je za široki, donji profil $\sim 1.56 \mathrm{~nm}$. Ovim poluširinama odgovaraju elektronske koncentracije od $\sim 0.8 \cdot 10^{15} \mathrm{~cm}^{-3}$ i $\sim 2.1 \cdot 10^{16} \mathrm{~cm}^{-3}$, respektivno [107]. Ove dve elektronske koncentracije su 
bliske odgovarajućim elektronskim koncentracijama dobijenih iz spektralne analize $\mathrm{H}_{\beta}$ linije u toku PEO procesa na aluminijumu [105].

\subsection{Morfologija površina oksidnih slojeva}

Izgled površine uzorka titanijuma pre i u ranim etapama PEO procesa u WSiA dat je na SI. 5.8. Jasno se uočava prisustvo pukotina i kanala na mestima gde su se lokalizovala mikro pražnjenja i lokalno razvijale visoke temperature za vrlo kratko vreme. Primećuje se i da se broj tih kanala smanjuje sa PEO vremenom, a njihov prečnik povećava. Sa porastom debljine oksidnog sloja, broj potencijalnih mesta gde struja može da prođe (pukotine i druge nepravilnosti u sloju) smanjuje pa se samim tim protok struje lokalizuje na preostalim “slabim mestima” proizvodeći mikro pražnjenja većih dimenzija, odnosno kanale većih prečnika. Sa porastom debljine oksidnog sloja očigledno je da raste i njegova hrapavost.
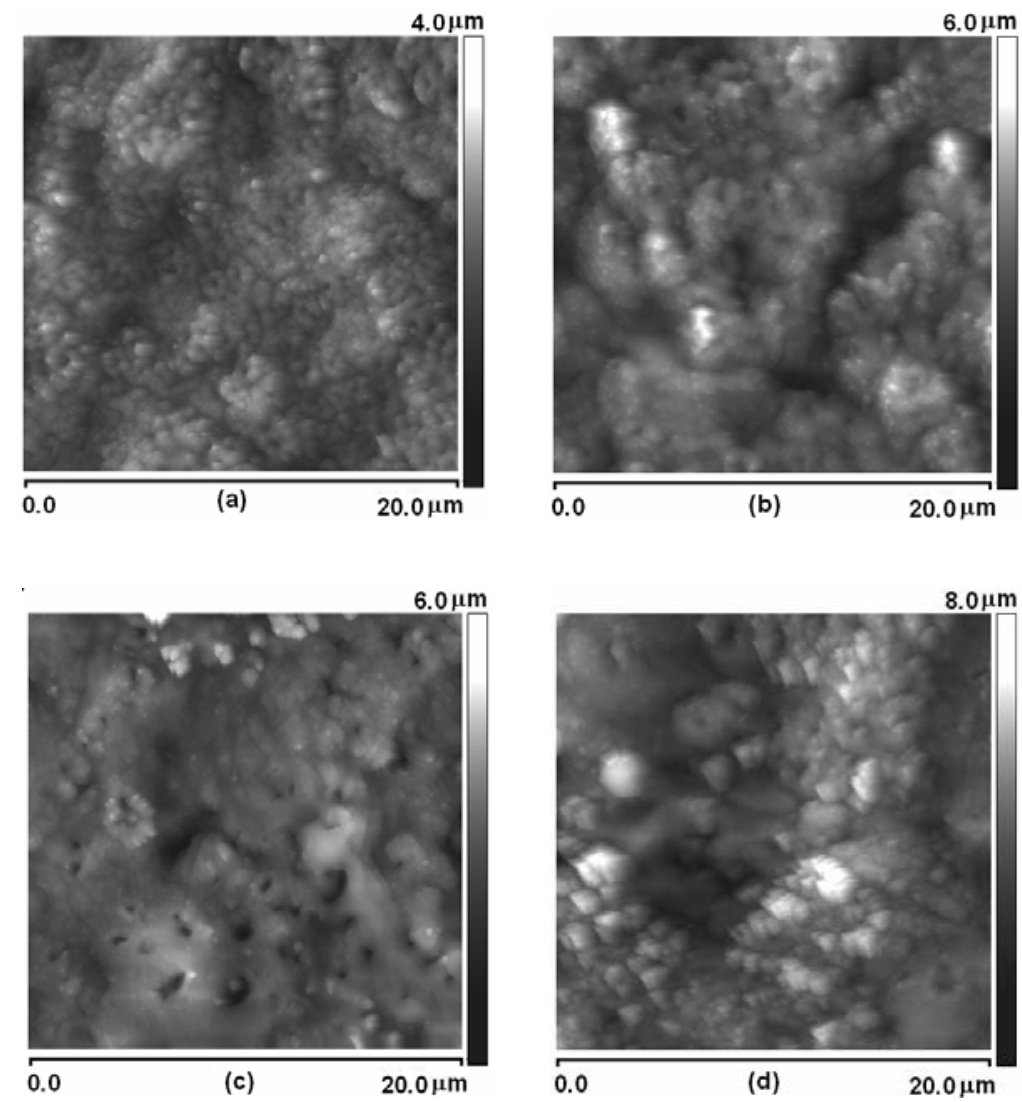

Slika 5.8. AFM slike oksidnih površina: (a) pre PEO procesa; (b) 30 s od početka PEO procesa; (c) $150 \mathrm{~s}$ od početka PEO procesa; (c) $600 \mathrm{~s}$ od početka PEO procesa. 


\subsection{Hemijski i fazni sastav oksidnih slojeva}

U početku anodizacije titanijuma, oksidni sloj raste na granicama titanijum-oksid i oksid-elektrolit kao rezultat migracije $\mathrm{O}^{2-} / \mathrm{OH}^{-}$i $\mathrm{Ti}^{4+}$ jona kroz oksidni sloj zahvaljujući postojanju jakog električnog polja. Početni rast oksidnog sloja na titanijumu je rezultat reakcije:

$$
\mathrm{T}_{\mathrm{i}}+2 \mathrm{H}_{2} \mathrm{O} \rightarrow \mathrm{T}_{\mathrm{i}} \mathrm{O}_{2}+4 \mathrm{H}^{+}+4 \mathrm{e}^{-}
$$

U toku PEO procesa visoke temperature i pritisci u kanalima za pražnjenje dovode do dekompozicije heteropoli kiselina [35]:

$$
\begin{aligned}
& \mathrm{H}_{4} \mathrm{SiW}_{12} \mathrm{O}_{40} \rightarrow \mathrm{S}_{\mathrm{i}} \mathrm{O}_{2}+12 \mathrm{WO}_{3}+2 \mathrm{H}_{2}, \\
& 2 \mathrm{H}_{3} \mathrm{PW}_{12} \mathrm{O}_{40} \cdot 6 \mathrm{H}_{2} \mathrm{O} \rightarrow \mathrm{P}_{2} \mathrm{O}_{5}+24 \mathrm{WO}_{3}+15 \mathrm{H}_{2} \mathrm{O} .
\end{aligned}
$$
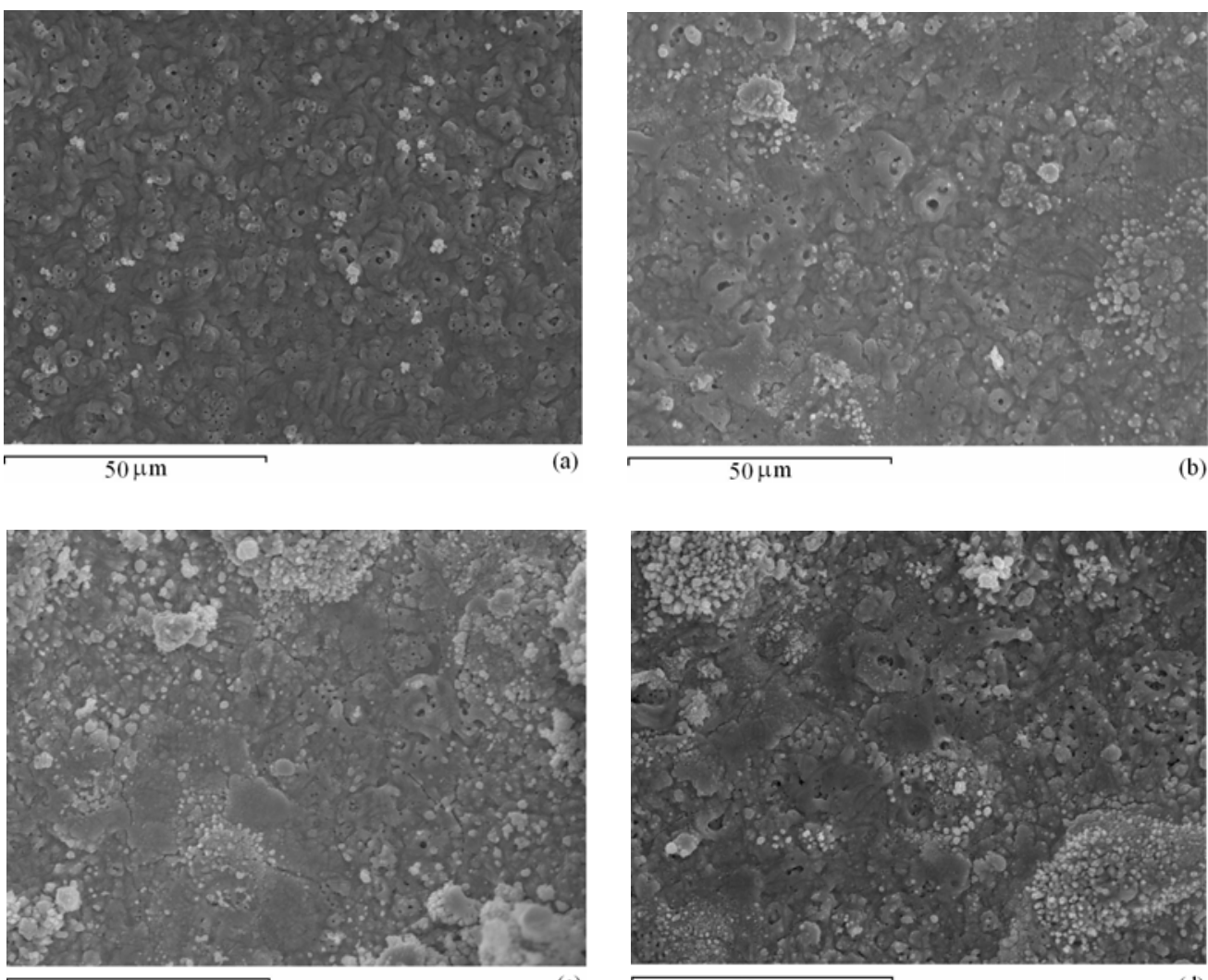

(c)

$50 \mu \mathrm{m}$

Slika 5.9. SEM površine formirane u WSiA u različitim etapama PEO procesa:

(a) $3 \mathrm{~min}$; (b) $10 \mathrm{~min}$; (c) $20 \mathrm{~min}$; (d) $30 \mathrm{~min}$. 
Na SI. 5.9 prizakane su SEM slike oksidnih površina dobijenih PEO procesom u WSiA. Integralni EDS spektri za dva PEO sloja na titanijumu sa SI. 5.9 (jedan nastao nakon 3 min i drugi nastao nakon 30 min PEO tretmana), prikazani su na SI. 5.10. U sastavu oba sloja potvrđeno je prisustvo kiseonika, titanijuma i volframa iz elektrolita. Očigledno je da sadržaj volframa na površini raste sa trajanjem PEO procesa, dok sadržaj titanijuma opada. $\mathrm{TiO}_{2}$ se formira oksidacijom titanijuma u toku PEO procesa na granici titanijum-oksid, i to je razlog zašto je sadržaj titanijuma veći u početnoj fazi PEO procesa. Kako se elementi iz elektrolita ugrađuju u toku PEO procesa u spoljašnji deo oksidnog sloja, to i sadržaj volframa raste ukazujući da se $\mathrm{WO}_{3}$ uglavnom formira u spoljašnjem delu oksidnog sloja.

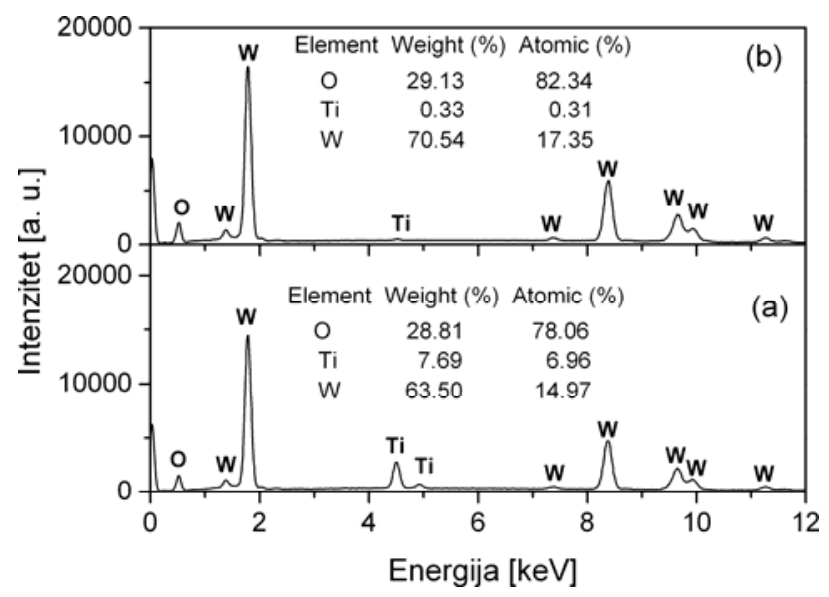

Slika 5.10. EDS analiza oksidnih slojeva dobijenih u WSiA u različitim etapama PEO procesa:

(a) $3 \mathrm{~min}$; (b) $30 \mathrm{~min}$.

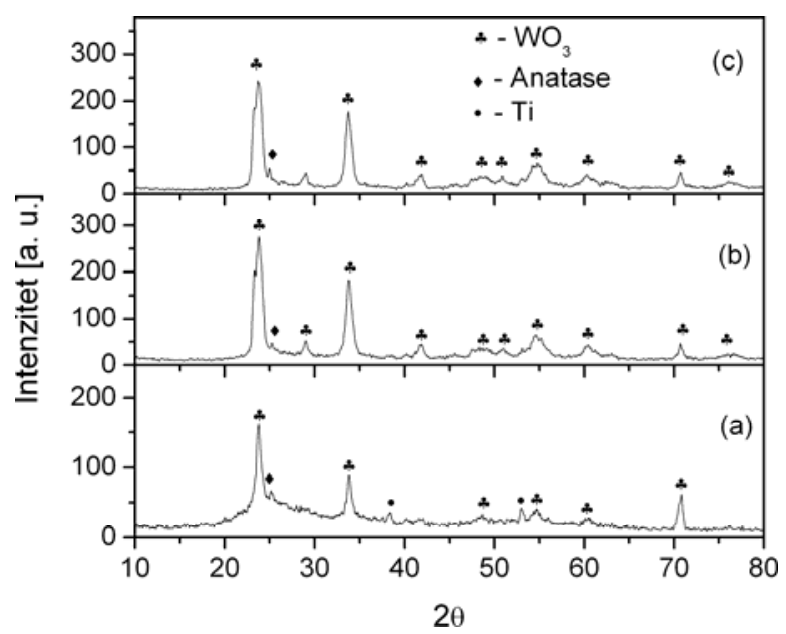

Slika 5.11. XRD spektri oksidnih slojeva dobijenih u WSiA u različitim etapama PEO procesa:

(a) $3 \mathrm{~min}$; (b) $15 \mathrm{~min}$; (c) $30 \mathrm{~min}$. 
XRD spektri oksidnih površina na titanijumu dobijene u WSiA je prikazan na SI. 5.11. Slojevi su delimično kristalizovani u formi oksida $\mathrm{WO}_{3} \mathrm{i}_{\mathrm{TiO}}$ (anatas), a najjače difrakcione linije u spektru potiču od elementarnog titanijuma iz substrata.

Na Sl. 5.12 prizakane su SEM slike oksidne površine dobijene PEO procesom u WPA. Integralni EDS spektri za dva PEO sloja na titanijumu sa SI. 5.12 (jedan nastao nakon 3 min PEO tretmana i drugi nastao nakon 30 min PEO tretmana), prikazani su na Sl. 5.13. U sastavu oba sloja takođe je potvrđeno prisustvo kiseonika, titanijuma i volframa iz elektrolita. Elementarni sastav je isti kao kod slojeva dobijenih u WSiA, sa razlikom da u slučaju PEO procesa u WPA odnos volframa, titanijuma i kiseonika ostaje skoro konstantan.

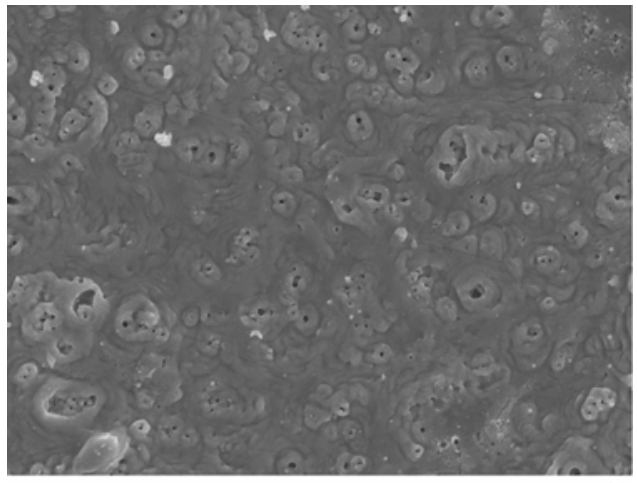

$50 \mu \mathrm{m}$

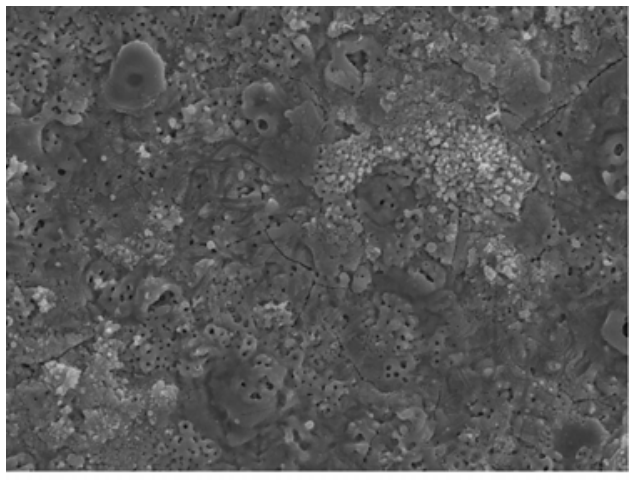

$50 \mu \mathrm{m}$ (a)

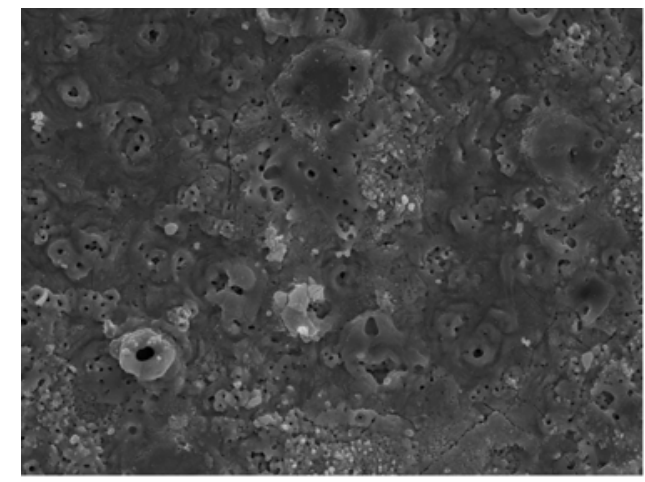

(c)

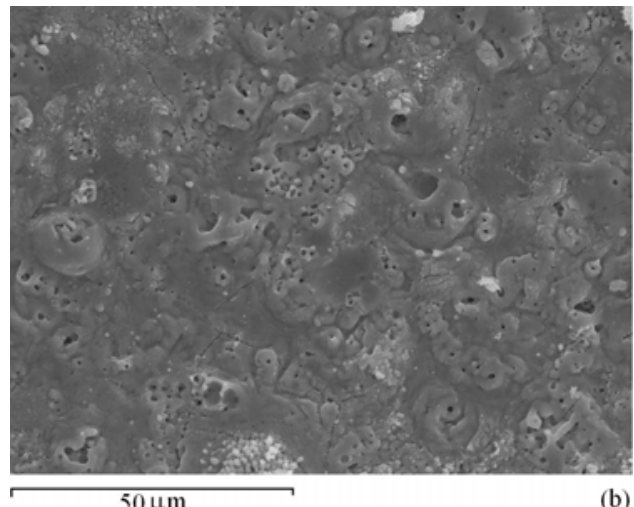

(b)

Slika 5.12. SEM površine formirane u WPA u različitim etapama PEO procesa:

(a) $3 \mathrm{~min}$; (b) $10 \mathrm{~min}$; (c) $20 \mathrm{~min}$; (d) $30 \mathrm{~min}$.

Dva su razloga zašto se to dešava. Prvi je što su prezentovani EDS rezultati integralni, odnosno predstavljaju elementarni sastav cele površine. Dobro je poznato da se elementarni sastav u spoljnjem delu oksidnog sloja dobijenog PEO tehnikom razlikuje od elementarnog 
sastava u kanalima za pražnjenje. Drugo, WPA je jača heteropoli kiselina od WSiA i rastvara dobijene oksidne slojeve mnogo više nego WSiA. To dovodi do proširenja kanala za pražnjenje oksidnih slojeva dobijenih u WPA, u odnosu na kanale dobijene u WSiA, odnosno do manje brzine rasta oksidnih slojeva. Posledica toga je skoro konstantan elementarni sastav oksidnih slojeva dobijenih u WPA.

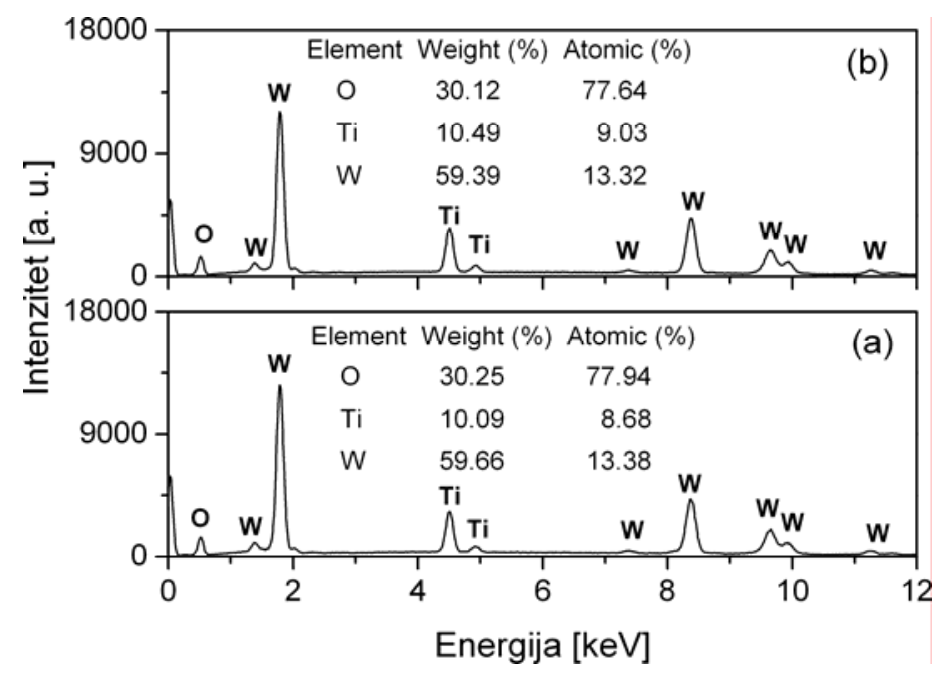

Slika 5.13. EDS analiza PEO slojeva u WPA u različitim etapama procesa: (a) 3 min; (b) 30 min.

XRD spektri oksidnih slojeva na titanijumu dobijenih u WPA su prikazani na Sl. 5.14. Slojevi su delimično kristalizovani u formi oksida $\mathrm{WO}_{3}$ i anatasa.

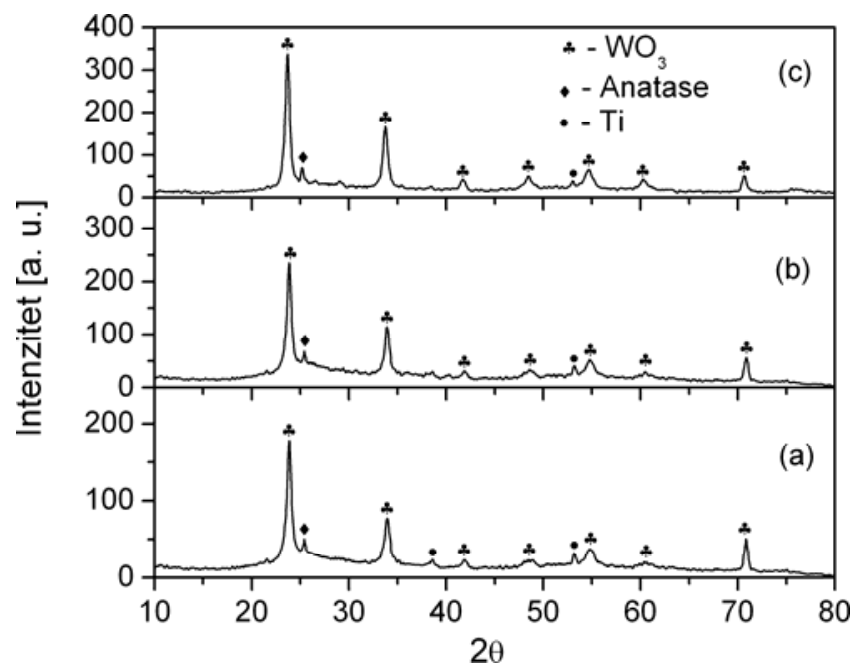

Slika 5.14. XRD spektri oksidnih slojeva dobijenih u WSiA u različitim etapama PEO procesa:

(a) $3 \mathrm{~min}$; (b) $30 \mathrm{~min}$; (c) $30 \mathrm{~min}$. 


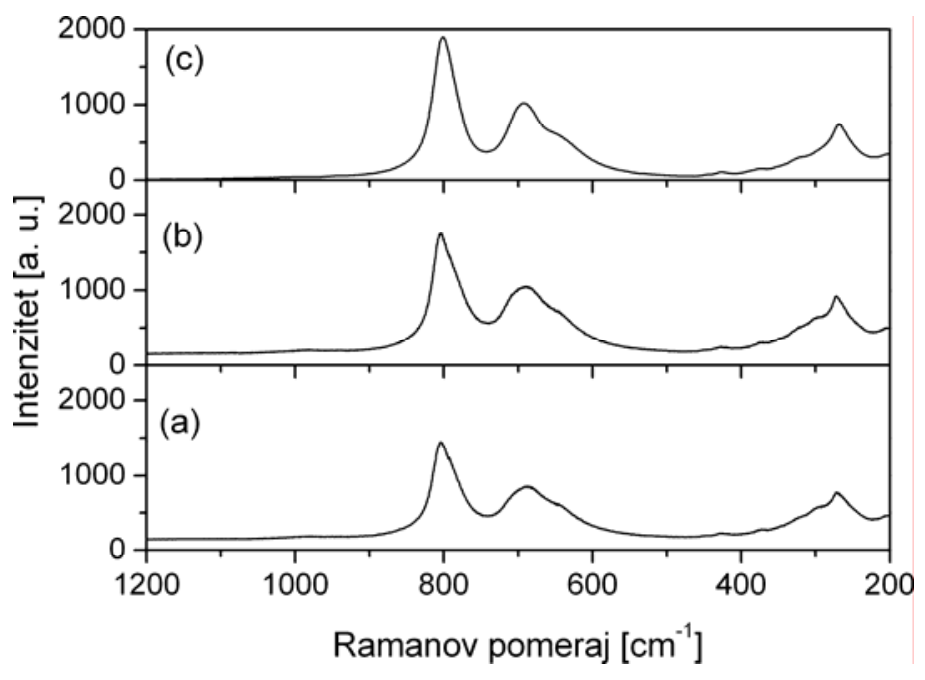

Slika 5.15. Ramanovi spektri: (a) referentni spektar uzorka WSiA nakon termalnog tretmana na $550{ }^{\circ} \mathrm{C}$;

(b) spektar oksidnog sloja dobijen nakon 5 min PEO tretmana;

(c) spektar oksidnog sloja dobijen nakon 15 min tretmana.

Ramanovi spektri oksidnih slojeva dobijeni u različitim fazama PEO procesa (SI. 5.14-b,c) su identični referentnom Ramanovom spektru WSiA izložene termalnom tretmanu na $550{ }^{\circ} \mathrm{C}$ (SI. 5.14-a). Ovo ukazuje da su se na površini titanijuma formirale volframske bronze. 


\section{PLAZMA ELEKTROLITIČKA OKSIDACIJA TANTALA}

Zahvaljujući visokoj tački topljenja, čvrstoći i izvanrednoj otpornosti na hemijske tretmane, tantal je interesantna podloga za dobijanje slojeva otpornih na visoke temperature, koroziju i jake hemijske tretmane [169-174].

Tantal oksid $\left(\mathrm{Ta}_{2} \mathrm{O}_{5}\right)$ se intenzivno koristi u industriji tankih filmova, izolatora, ali i kao antireflektujući materijal $[175,176]$. Smatra se jednim od najboljih materijala za izradu sočiva i optičkih vlakana i sve to zahvaljujući svojoj hemijskoj i mehaničkoj stabilnosti, vrlo niskim optičkim gubicima sa dužinom vlakna i visokim refraktornim indeksom (n 2.2 na talasnoj dužini $633 \mathrm{~nm}$ ) [177-179]. Pored ostalog, materijali koji sadrže tantal pokazuju i izuzetnu otpornost na toplotne tretmane [180].

Neke od tehnika dobijanja oksidnih slojeva na tantalu podrazumevaju termalnu oksidaciju [181], anodnu oksidaciju [182], spaterovanje [183], depoziciju fotohemijskim uparavanjem [184] (Chemical Vapour Deposition, CVD), tehnike na granici metal-organska faza [185] i depoziciju pulsnim laserom ( Pulsed Laser Deposition, PLD) [186].

Uprkos brojnim prednostima oksidnih slojeva na tantalu, ne postoji veliki broj naučnih studija koje se bave istraživanjem PEO procesa na tantalu. Naročito su interesantni slojevi sa ugrađenim volframom koji se ističu po svojim odličnim katalitičkim, poluprovodničkim i antikorozivnim osobinama [21,22]. U ovom poglavlju biće predstavljena istraživanja PEO procesa na tantalu u WSiA [187].

\subsection{Eksperimentalni podaci}

Oksidne površine su formirane na uzorcima tantala dimenzija $25 \mathrm{~mm}$ x $5 \mathrm{~mm}$ x 0.12 mm i čistoće 99.9\%. Pre same anodizacije, uzorci su očišćeni acetonom, etanolom i destilovanom vodom u ultrazvučnoj kadi. Tako očišćeni uzorci, sušeni su u struji toplog vazduha i anodizirani u $0.001 \mathrm{M}$ vodenom rastvoru WSiA. Anodizacija tantala je vršena u elektrolitičkoj ćeliji u režimu konstantne gustine struje od $70 \mathrm{~mA} / \mathrm{cm}^{2}$. U toku anodizacije, temperatura elektrolita je održavana konstantnom $(21 \pm 1){ }^{\circ} \mathrm{C}$. 


\subsection{Optička karakterizacija i analiza PEO procesa na tantalu u realnom vremenu}

\subsubsection{Zavisnost napona $i$ intenziteta luminescencije od vremena anodizacije}

Na Sl. 6.1 data je tipična zavisnost napona anodizacije i intenziteta luminescencije u toku anodizacije tantala u WSiA. Očigledno je da tantal ne pokazuje galvanoluminescentne fenomene koji se javljaju kod aluminijuma. Na naponskoj krivi jasno se uočavaju tri etape PEO procesa, slično kao kod aluminijuma. Početak anodizacije (prvih $20 \mathrm{~s}$ procesa) je očekivano praćen linearnim porastom napona anodizacije sa nagibom od $16.7 \mathrm{~V} / \mathrm{s}$ [188]. Ova etapa anodizacije podseća na običnu anodizaciju i praćena je formiranjem kompaktnog, barijernog, oksidnog sloja. Uniformni rast barijernog oksidnog sloja prekinut je dielektričnim probojem (dostizanjem vrednosti napona od oko $420 \mathrm{~V}$ ), što se manifestuje odstupanjem naponske krive od linearnosti i pojavom mikro pražnjenja na površini tantala (Sl. 6.2-b.) [189].

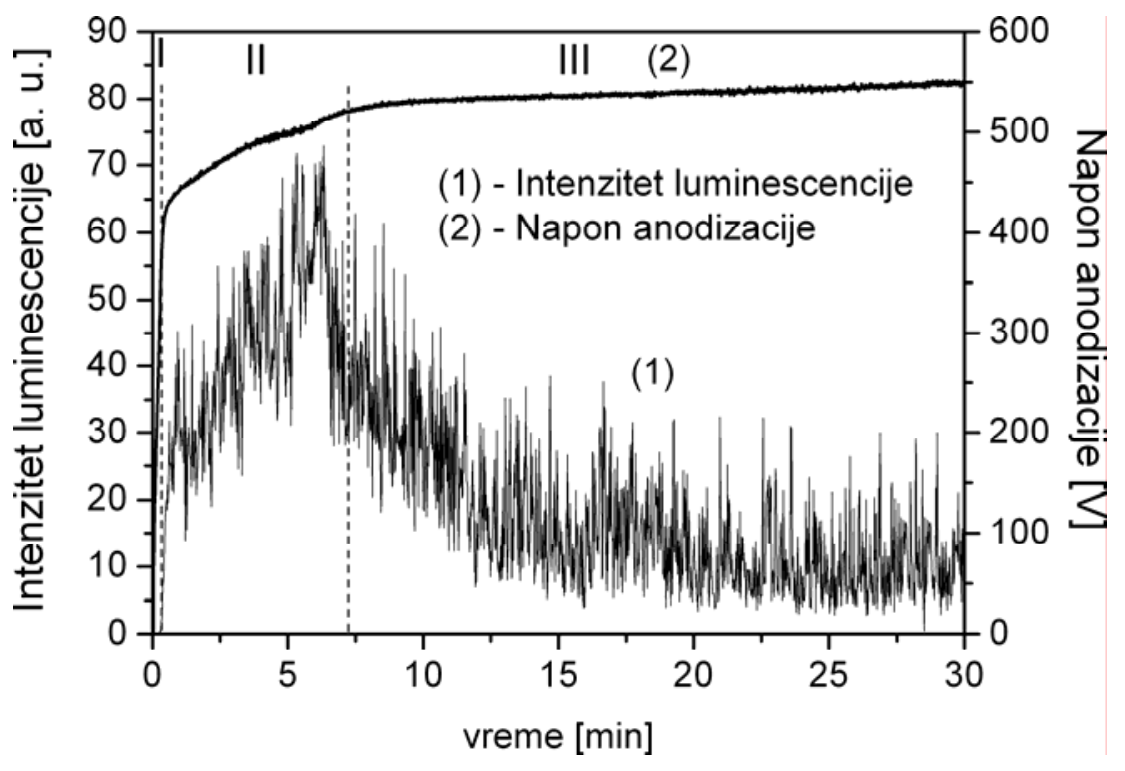

Slika 6.1. Zavisnost napona i intenziteta luminescencije od vremena anodizacije.

\subsubsection{Dinamika i distribucija mikro pražnjenja u toku PEO procesa}

Na Sl. 6.2 prikazane su vizuelne karakteristike mikro pražnjenja u različitim etapama PEO procesa. Intenzivno oslobađanje gasa uočava se već nakon nekoliko sekundi od početka anodizacije (SI. 6.2-a). Mala mikro pražnjenja, sa srednjom površinom poprečnog preseka od 
$\sim 0.05 \mathrm{~mm}^{2}$, vidljiva su 20 sekundi nakon početka anodizacije, praćena formiranjem mehura gasa na oksidnoj površini (Sl. 6.2-b). Kako PEO proces napreduje tako i veličina mikro pražnjenja raste dok se, istovremeno njihov broj smanjuje (Sl. 6.2 c-h).

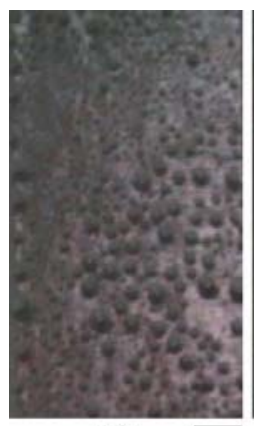

(a) $1 \overline{\mathrm{mm}}$

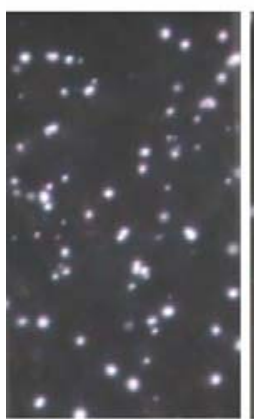

(e)

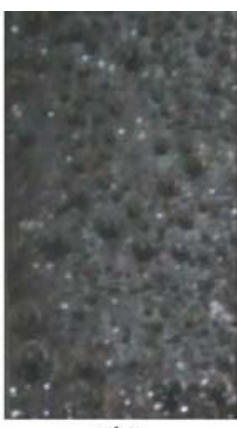

(b)

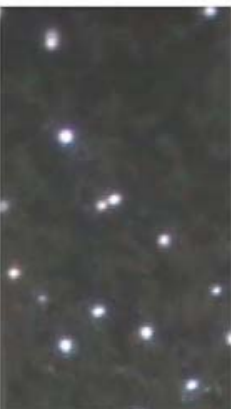

(f)

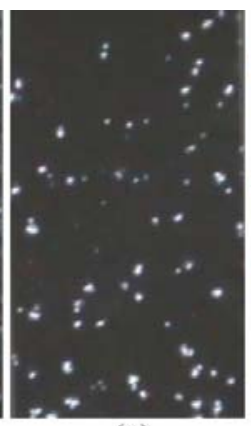

(c)

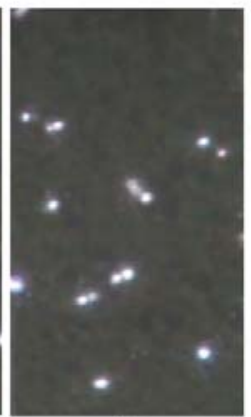

(g)

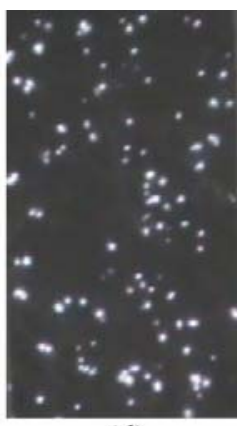

(d)

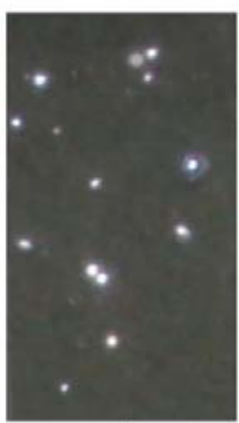

(h)

Slika 6.2. Pojava mikro pražnjenja u različitim etapama PEO procesa: (a) $10 \mathrm{~s}$; (b) $20 \mathrm{~s}$; (c) $1 \mathrm{~min}$; (d) $3 \mathrm{~min}$; (e) $5 \mathrm{~min}$; (f) $15 \mathrm{~min}$; (g) $30 \mathrm{~min}$; (h) $45 \mathrm{~min}$.

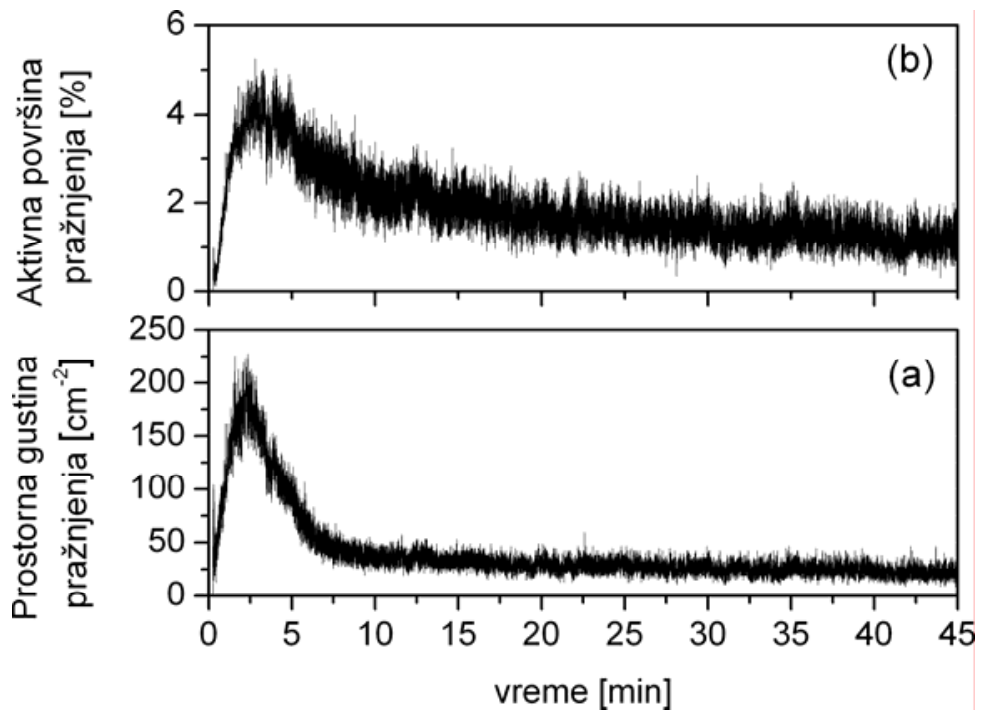

Slika 6.3. Karakteristike mikro pražnjenja u različitim etapama PEO procesa: (a) prostorna gustina mikro pražnjenja; (b) procenat oksidne površine istovremeno pokrivena aktivnim mestima za mikro pražnjenje. 
Evolucija prostorne gustine mikro pražnjenja je prikazana na Sl. 6.3-a. Prostorna gustina mikro pražnjenja je najveća nakon 2.5 minuta od početka PEO procesa, a zatim se postepeno smanjuje narednih 5 minuta sa $\sim 225 \mathrm{~cm}^{-2}$ do $\sim 50 \mathrm{~cm}^{-2}$ i potom ostaje približno konstantna. Procenat oksidne površine, istovremeno pokrivene aktivnim mestima za mikro pražnjenje, takođe je najveći posle 2.5 minuta od početka PEO procesa ( $5 \%)$ i potom monotono opada (SI. 6.3-b).
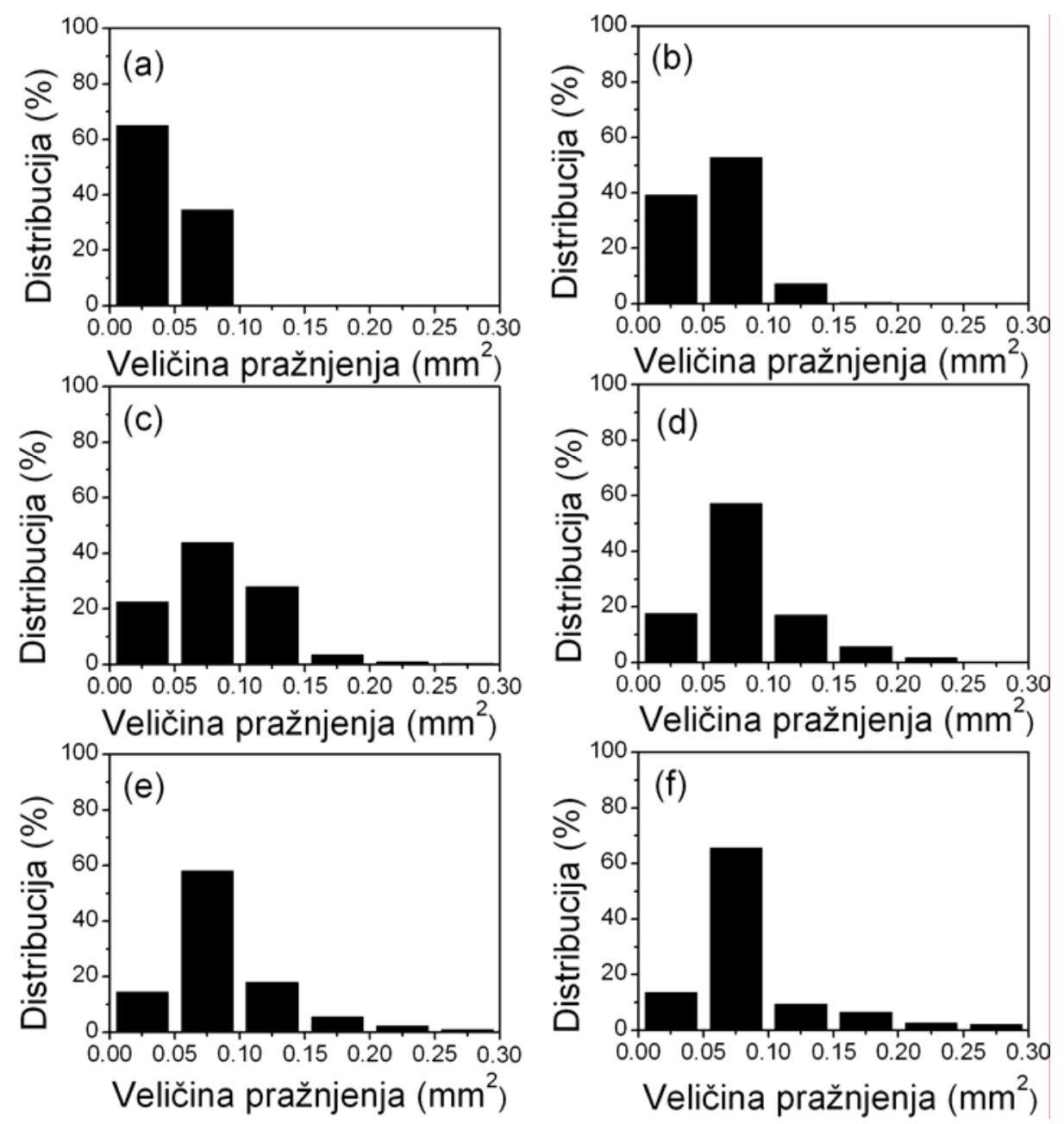

Slika 6.4. Dimenzionalna distribucija mikro pražnjenja u različitim etapama PEO procesa:

(a) $2.5 \mathrm{~min}$; (b) $5 \mathrm{~min}$; (c) $10 \mathrm{~min}$; (d) $15 \mathrm{~min}$; (e) $30 \mathrm{~min}$; (f) $45 \mathrm{~min}$.

Dimenzionalna distribucija mikro pražnjenja tokom PEO procesa je prikazana na SI. 6.4. $U$ toku čitavog PEO procesa zastupljena su relativno mala mikro pražnjenja $\left(<0.1 \mathrm{~mm}^{2}\right)$. Na samom početku PEO procesa njihova koncentracija dostiže $100 \%$ od ukupne populacije (SI. 6.4-a), da bi nakon 45 min od početka anodizacije, opala na $75 \%$ (Sl. 6.4-f). Procenat 
mikro pražnjenja srednje veličine $\left(0.1 \mathrm{~mm}^{2}\right.$ do $\left.0.2 \mathrm{~mm}^{2}\right)$ je zanemarljiv na samom početku procesa, ali raste sa PEO vremenom i nakon 10 min dostiže svoju maksimalnu vrednost od 32 \%. Na samom kraju PEO procesa, procenat mikro pražnjenja srednjih veličina iznosi oko $17 \%$. Velika mikro pražnjenja $\left(>0.2 \mathrm{~mm}^{2}\right)$ se mogu detektovati tek u završnim fazama PEO procesa.

\subsubsection{Spektralna karakterizacija PEO procesa}

Tipičan emisioni spektar mikro pražnjenja PEO procesa na tantalu, u spektralnom opsegu od $380 \mathrm{~nm}$ do $850 \mathrm{~nm}$ je prikazan na Sl. 6.5. Detaljniji emisioni spektri u opsegu od $380 \mathrm{~nm}$ do $480 \mathrm{~nm}$ i u opsegu od $700 \mathrm{~nm}$ do $850 \mathrm{~nm}$ su prikazani na Sl. 6.5-b i c, respektivno. Jasno definisane spektralne linije ukazuju na postojanje elektronskih prelaza. Za identifikaciju atomskih i jonskih linija korišćena je NIST-ova baza podataka. Jake linije $\mathrm{H}_{\alpha}$ (656.27 nm) i $\mathrm{H}_{\beta}(486.13 \mathrm{~nm})$ pripadaju Balmerovoj seriji vodonika. Jake linije su i linije kiseonika O I na 844.62 nm, 844.64 nm i 844.68 nm i O I na 777.19 nm, 777.42 nm, 777.66 nm. Takođe su detektovane i mnoge linije koje potiču od O I, O II i H ${ }_{\gamma}(434.05$ nm) (Sl. 6.5). Kontinualna emisija između $380 \mathrm{~nm}$ i $850 \mathrm{~nm}$ je posledica radijativne rekombinacije elektrona, ubačenih u provodnu zonu oksida i umnoženih u lavinskim procesima, na nečistoćama u oksidnim slojevima [98,167]. Za razliku od spektara dobijenih u slučaju PEO procesa na aluminijumu, detektovane spektralne linije potiču isključivo od elemenata prisutnih u elektrolitu. [105]. Izostanak elektronskih prelaza koji potiču od substrata je posledica mnogo više temperature topljenja tantala $\left(\sim 3000{ }^{\circ} \mathrm{C}\right) \mathrm{u}$ odnosu na aluminijum $\left(660^{\circ} \mathrm{C}\right)$.

Slično, kao i slučaju PEO procesa na titanijumu, za merenje elektronskih koncentracija korišćena je Balmerova linija $\mathrm{H}_{\beta}$ [189]. Intenzivna Balmerova linija $\mathrm{H}_{\alpha}$ je jako samoapsorbovana, dok je Balmerova linija $\mathrm{H}_{\gamma}$ slaba i u PEO procesu interferira sa O II linijama. $\mathrm{H}_{\beta}$ linija se može pouzdano fitovati samo sa dva Lorencova profila sa poluširinama linije na polovini maksimuma od $\sim 0.18 \mathrm{~nm}$ i $\sim 1.56 \mathrm{~nm}$. Ovim poluširinama odgovaraju elektronske koncentracije od $\sim 0.9 \cdot 10^{15} \mathrm{~cm}^{-1} \mathrm{i} \sim 2.2 \cdot 10^{16} \mathrm{~cm}^{-1}$, respektivno. Ove dve elektronske koncentracije su bliske odgovarajućim elektronskim koncentracijama dobijenim iz spektralne analize $\mathrm{H}_{\beta}$ linije $\mathrm{u}$ toku PEO procesa na aluminijumu i titanijumu. 

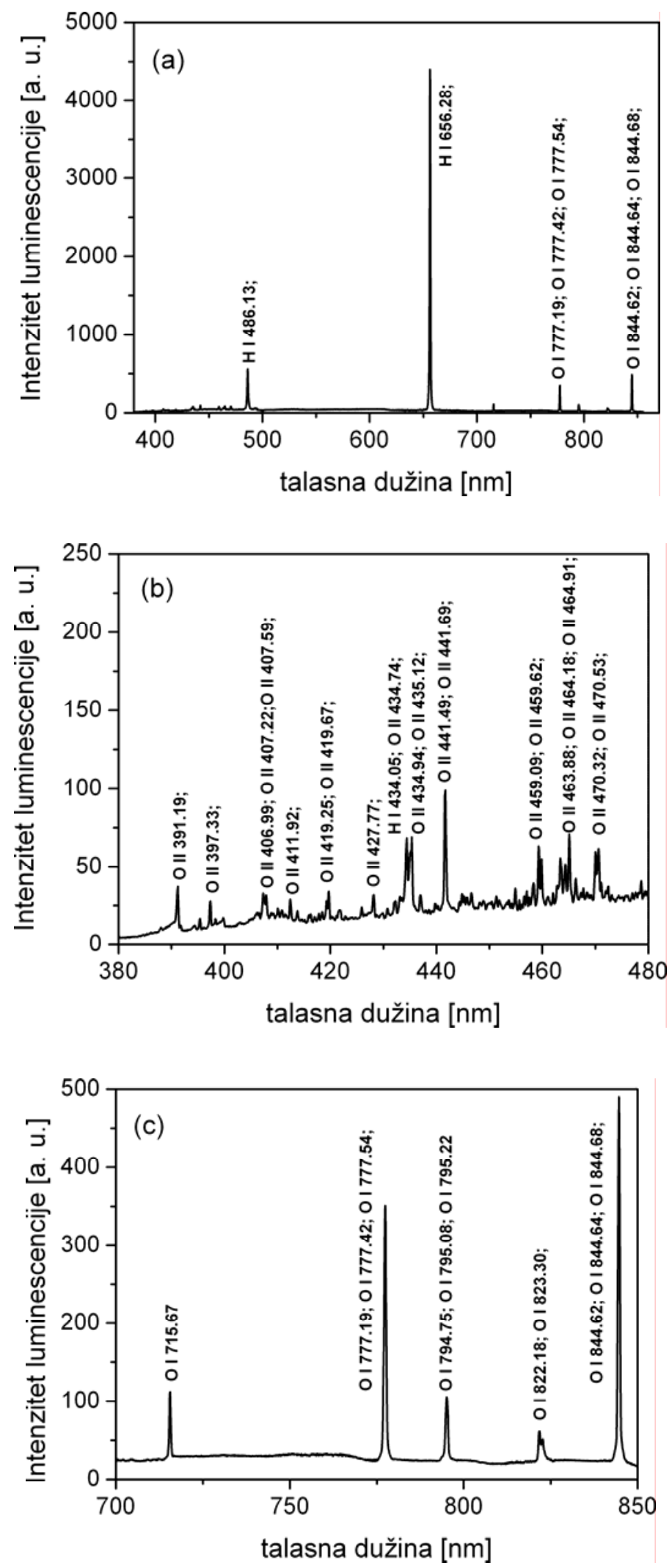

Slika 6.5. Optičko emisioni spektar dobijen u toku PEO procesa u opsegu talasnih dužina:

(a) $380 \mathrm{~nm}-850 \mathrm{~nm}$; (b) $380 \mathrm{~nm}-480 \mathrm{~nm}$; (c) $700 \mathrm{~nm}-850 \mathrm{~nm}$. 


\subsection{Morfologija površina oksidnih slojeva}

Evaluacija morfologije PEO površina dobijenih na tantalu prikazana je na Sl. 6.6. Pre nego što se u toku anodizacije dostigne napon proboja, na površini tantala formira se kompaktan barijerni oksidni sloj (Sl. 6.6-a.). Nakon postizanja napona proboja, površina uzorka postaje bogata mnogobrojnim pukotinama, porama i kanalima. U toku PEO procesa dijametar kanala za mikro pražnjenja raste, a njihov broj se smanjuje.
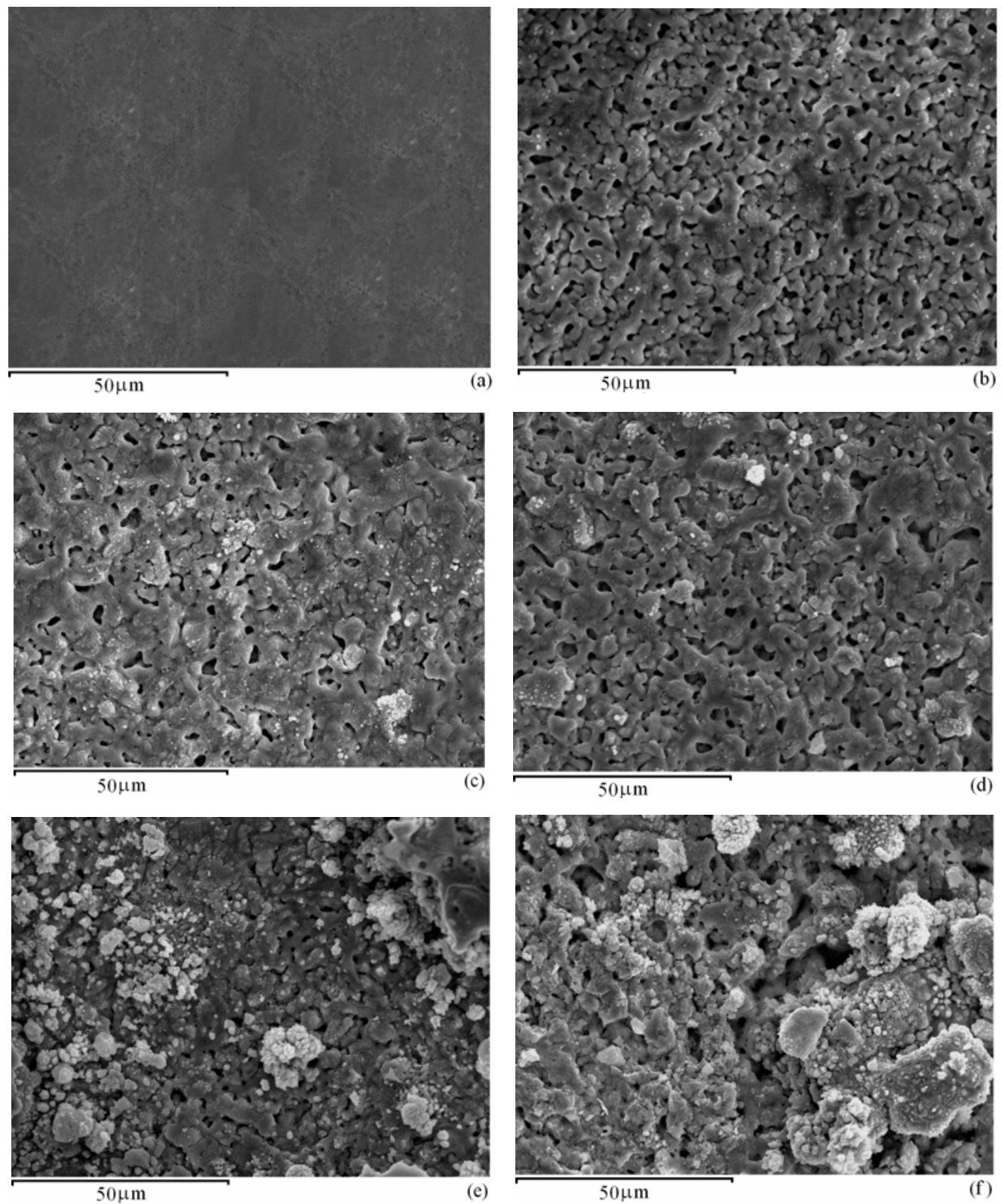

Slika 6.6. SEM slika oksidnih površina u različitim etapama PEO procesa:

(a) $15 \mathrm{~s}$; (b) $3 \mathrm{~min}$; (c) $10 \mathrm{~min}$; (d) $15 \mathrm{~min}$; (e) $30 \mathrm{~min}$; (d) $45 \mathrm{~min}$. 
Na Sl. 6.7 prikazane su trodimenzionalne AFM slike dobijene u različitim etapama PEO procesa. U početku PEO procesa kanali za pražnjenje su ravnomerno raspoređeni i oksidne površine imaju manju hrapavost. Kako broj kanala za pražnjenje opada sa vremenom PEO procesa, neuniformnosti na oksidnoj površini se javljaju što dovodi do povećanja hrapavosti. Uticaj vremena PEO procesa na hrapavost oksidnih površina prikazan je na SI.

6.8 .
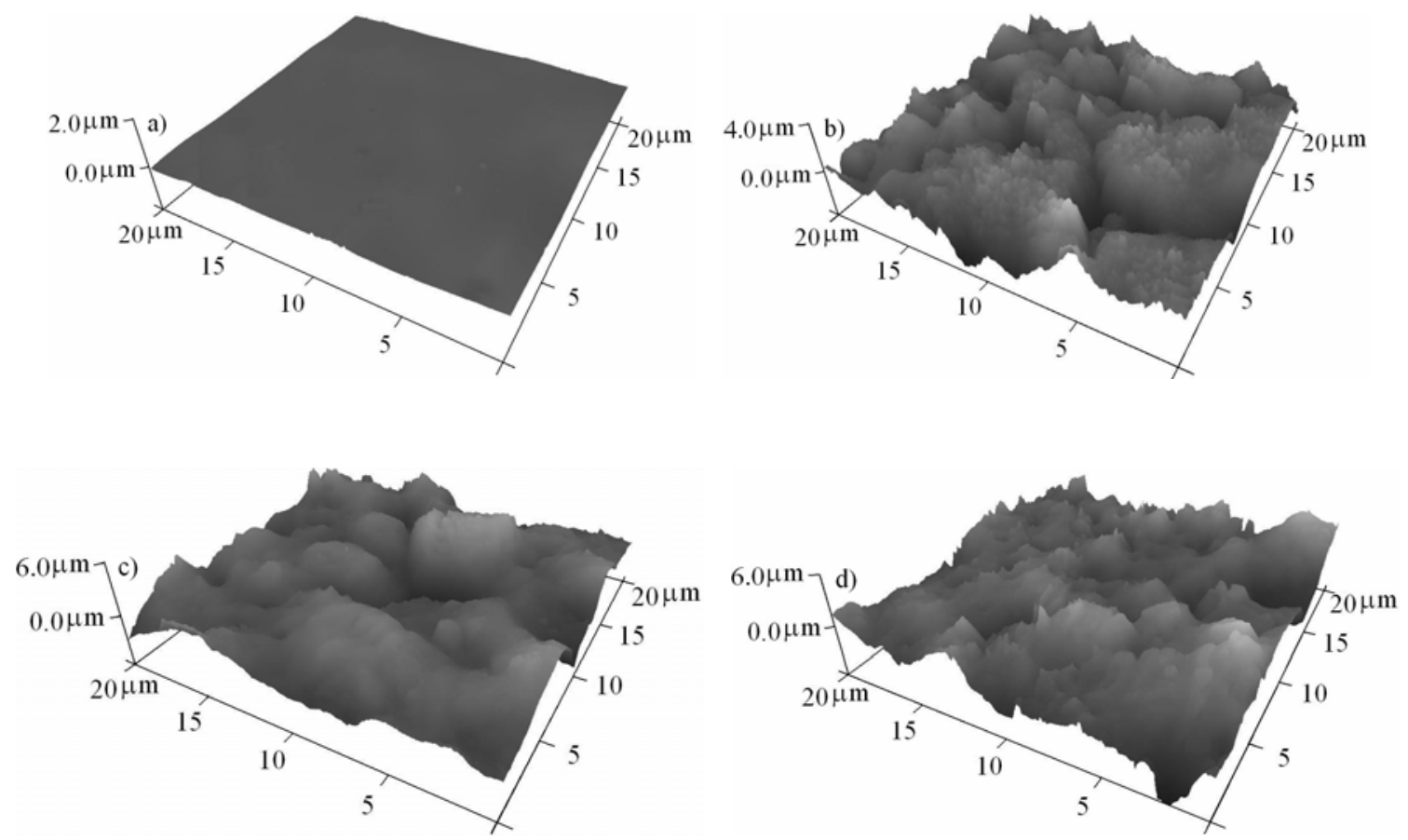

Slika 6.7. Trodimenzionalne AFM slike površina oksidnih slojeva u različitim etapama PEO procesa:

(a) $15 \mathrm{~s}$; (b) $3 \mathrm{~min}$; (c) $10 \mathrm{~min}$; (d) $30 \mathrm{~min}$.

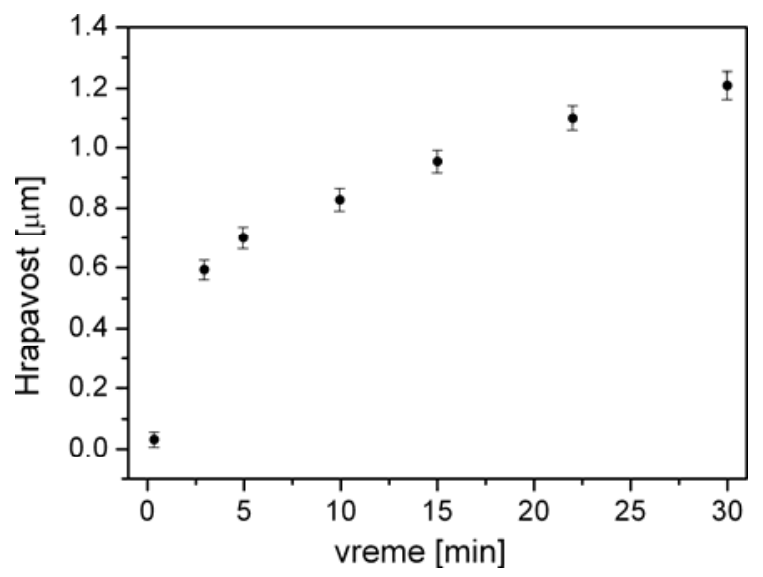

Slika 6.8. Uticaj vremena PEO procesa na hrapavost površina oksidnih slojeva. 
Na Sl. 6.9 prikazane su SEM slike poprečnog preseka oksidnih površina na tantalu. Prosečna debljina sloja u toku čitavog procesa raste brzinom od oko $1.3 \mu \mathrm{m} / \mathrm{min}$. Slojevi pokazuju tipičnu mikrostrukturu sa dva jasno izražena regiona: tanji, kompaktni unutrašnji sloj pri samom substratu i udaljeni porozni sloj.
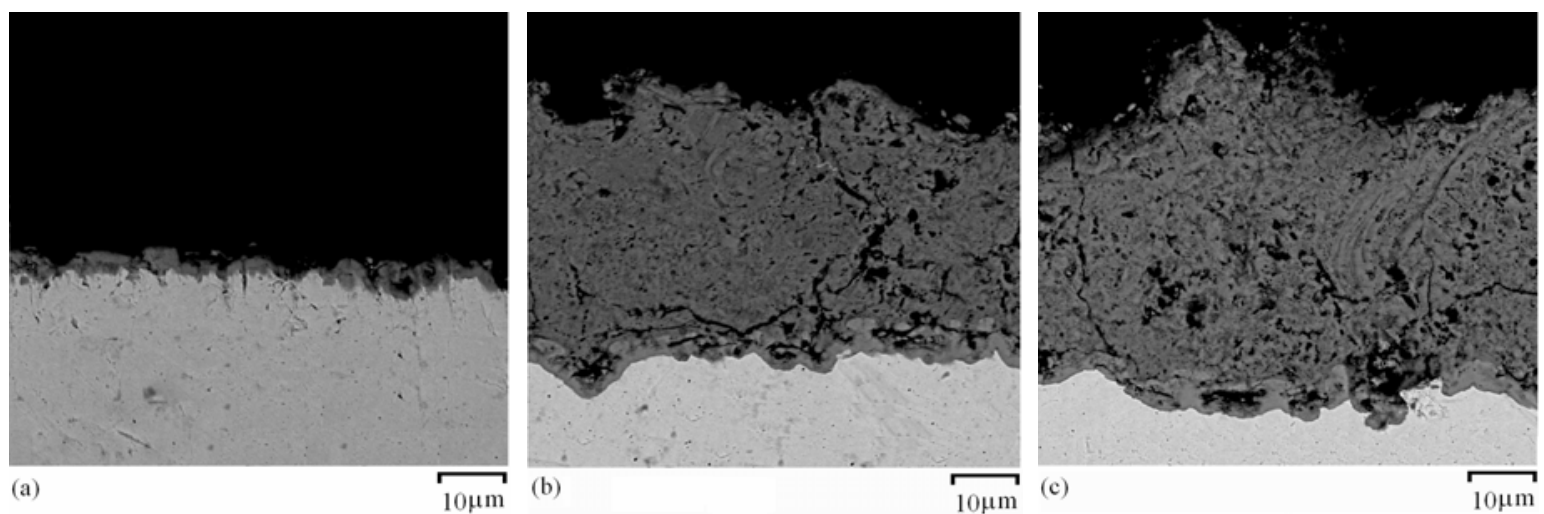

Slika 6.9. SEM slika poprečnog preseka oksidnih slojeva dobijenih PEO procesom:

(a) $10 \mathrm{~min}$ : (b) $30 \mathrm{~min}$; (c) $45 \mathrm{~min}$.

\subsection{Hemijski i fazni sastav oksidnih slojeva}

Kao što je već rečeno, PEO proces u sebi kombinuje proces formiranja oksida, njegovog rastvaranja u elektrolitu i dielektrični proboj. Na samom početku anodizacije tantala, oksidni sloj raste na granici tantal-oksid i oksid-elektrolit migracijom $\mathrm{O}^{2-} / \mathrm{OH}^{-}$i Ta ${ }^{5+}$ jona kroz oksidni sloj u prisustvu jakog električnog polja. U isto vreme, male količine nekih komponenti iz elektrolita se ugrađuju u sam oksidni sloj.

Glavna hemijska reakcija na granici tantal-oksid je:

$$
\mathrm{Ta} \rightarrow \mathrm{Ta}^{5+}+5 \mathrm{e}^{-}
$$

dok je na granici oksid-elektrolit:

$$
4 \mathrm{H}_{2} \mathrm{O}-4 \mathrm{e}^{-} \rightarrow \mathrm{O}_{2} \uparrow+4 \mathrm{H}^{+}+2 \mathrm{H}_{2} \mathrm{O}
$$

Ukupna reakcija je:

$$
2 \mathrm{Ta}+5 \mathrm{H}_{2} \mathrm{O}-10 \mathrm{e}^{-} \rightarrow \mathrm{Ta}_{2} \mathrm{O}_{5}+10 \mathrm{H}^{+}
$$


Usled pojavljivanja mesta sa lokalizovano visokom temperaturama i pritiscima dolazi do termalnog raspada WSiA [165]:

$$
\mathrm{H}_{4} \mathrm{SiW}_{12} \mathrm{O}_{40} \rightarrow \mathrm{S}_{\mathrm{i}} \mathrm{O}_{2}+12 \mathrm{WO}_{3}+2 \mathrm{H}_{2} \mathrm{O}
$$

U Tabeli 6.1 su dati rezultati EDS analize sastava oksidnih slojeva dobijenih PEO tehnikom na tantalu u vodenom rastvoru WSiA sa Sl. 6.6. Glavni elementi prisutni u dobijenim oksidnim slojevima su tantal, kiseonik, volfram i silicijum. Procentni sastav kiseonika se veoma malo menja sa vremenom PEO procesa, dok se procenat volframa povećava, a tantala smanjuje.

Tabela 6.1. Rezulatati EDS analize oksidnih površina sa Sl. 6.6.

\begin{tabular}{c|cccc}
\hline & \multicolumn{4}{|c}{ Atomski (\%) } \\
Uzorak & $\mathrm{O}$ & $\mathrm{Ta}$ & $\mathrm{W}$ & $\mathrm{Si}$ \\
\hline Fig. 6.6-a & 76.0 & 24.0 & 3.5 & 7.1 \\
Fig. 6.6-b & 72.3 & 17.1 & 10.0 & 3.0 \\
Fig. 6.6-c & 75.6 & 11.4 & 10.2 & $<0.3$ \\
Fig. 6.6-d & 80.3 & 9.5 & 18.4 & $<0.3$ \\
Fig. 6.6-e & 79.8 & 1.8 & 27.6 & $<0.3$ \\
Fig. 6.6-f & 71.0 & 1.4 & & \\
\hline
\end{tabular}

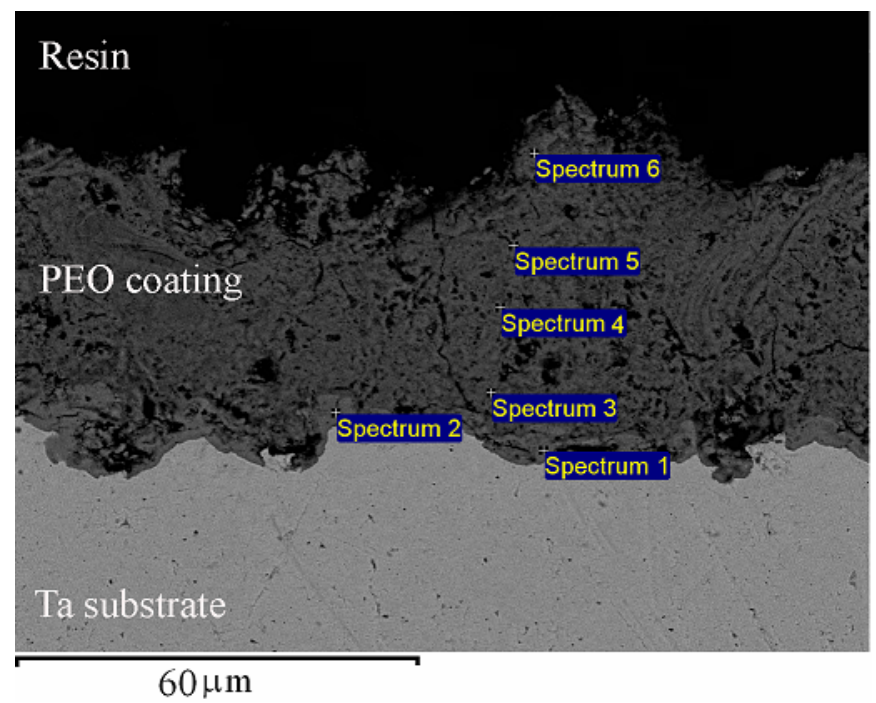

Slika 6.10. SEM slika poprečnog preseka uzorka Ta anodiziranog $45 \mathrm{~min}$. 
Sl. 6.10. pokazuje poprečni presek uzorka anodiziranog 45 min sa označenim regiona na kojima su vršena EDS merenja. Rezultati EDS analize su dati u Tabeli 6.2. Očigledno je da se hemijski elementi iz elektrolita u toku PEO procesa ugrađuju u oksidni sloj. Sadržaj Ta je veći u unutrašnjem sloju. Nasuprot tome, procentni sadržaj W je veći u poroznom, udaljenijem sloju ukazujući da se $\mathrm{WO}_{3}$ uglavnom formira u spoljašnjem sloju. Sadržaj Si je ispod granice detekcije sistema.

Tabela 6.2. Rezulatati EDS analize poprečnog preseka uzorka anodiziranog 45 min.

\begin{tabular}{lccc}
\hline & \multicolumn{2}{c}{ Atomski (\%) } & \\
& $\mathrm{O}$ & $\mathrm{Ta}$ & $\mathrm{W}$ \\
\hline Spectrum 1 & 73.08 & 26.20 & 0.72 \\
Spectrum 2 & 74.54 & 24.74 & 0.73 \\
Spectrum 3 & 79.25 & 0.39 & 20.36 \\
Spectrum 4 & 78.13 & 0.00 & 21.87 \\
Spectrum 5 & 77.53 & 0.00 & 22.47 \\
Spectrum 6 & 76.85 & 0.00 & 23.15 \\
& & & \\
\hline
\end{tabular}

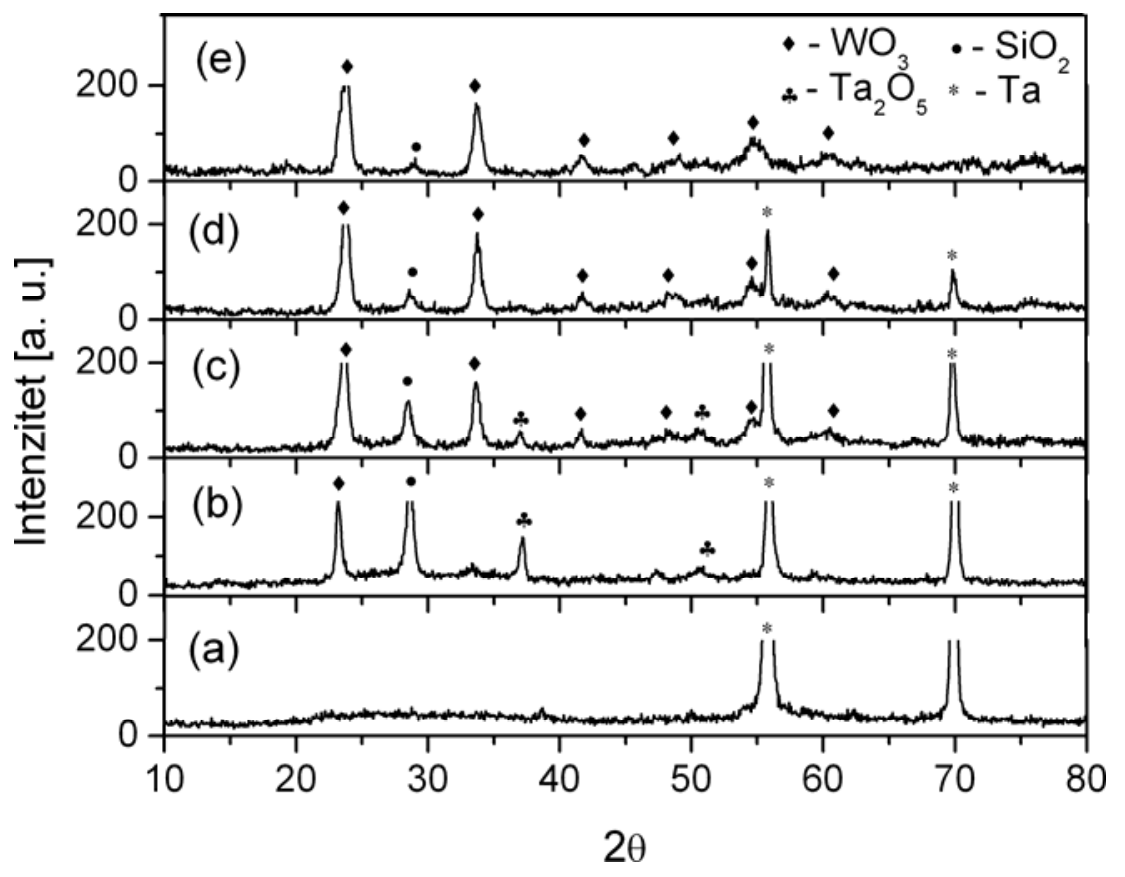

Slika 6.11. XRD spektri oksidnih slojeva u različitim etapama PEO:

(a) $15 \mathrm{~s}$; (b) $5 \mathrm{~min}$; (c) $15 \mathrm{~min}$; (d) $30 \mathrm{~min}$; (e) $60 \mathrm{~min}$. 
XRD spektri za pet oksidnih slojeva formiranih PEO procesom na tantalu prikazani su na Sl. 6.11. Pre postizanja napona proboja prisutan je samo amorfni oksidni sloj tantala (SI. 6.11-a). Elementarni tantal potiče uglavnom iz substrata i stoga su te difrakcione linije i najjače. Nakon dostizanja napona proboja, oksidni sloj je delimično kristalizovan i prisutne su kristalne faze $\mathrm{Ta}_{2} \mathrm{O}_{5}, \mathrm{WO}_{3} \mathrm{i} \mathrm{SiO}_{2}$. Sadržaj $\mathrm{WO}_{3}$ se povećava sa PEO vremenom dok se sadržaj $\mathrm{Ta}_{2} \mathrm{O}_{5}$ i $\mathrm{SiO}_{2}$ istovremeno smanjuje. Na Sl. 6.12 su prikazane fotografije površina tantala nakon različitog vremena trajanja PEO procesa. Zelene površine su karakteristične za $\mathrm{WO}_{3}[190]$.

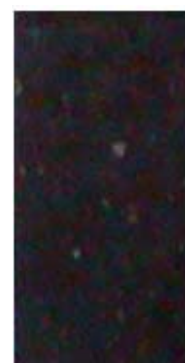

(a)

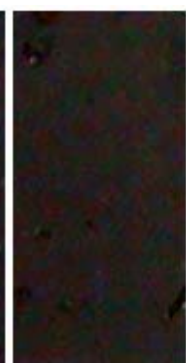

(b)

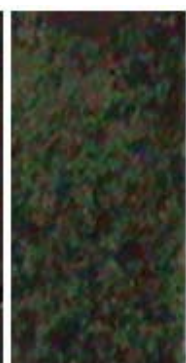

(c)

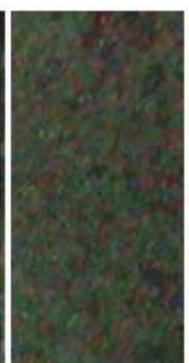

(d)

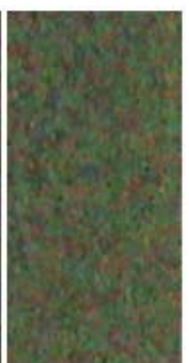

(e)

Slika 6.12. Slike površina oksidnih slojeva na tantalu formiranih u različitim etapama PEO procesa: (a) $5 \mathrm{~min}$; (b) $10 \mathrm{~min}$; (c) $15 \mathrm{~min}$; (d) $30 \mathrm{~min}$; (e) $45 \mathrm{~min}$.

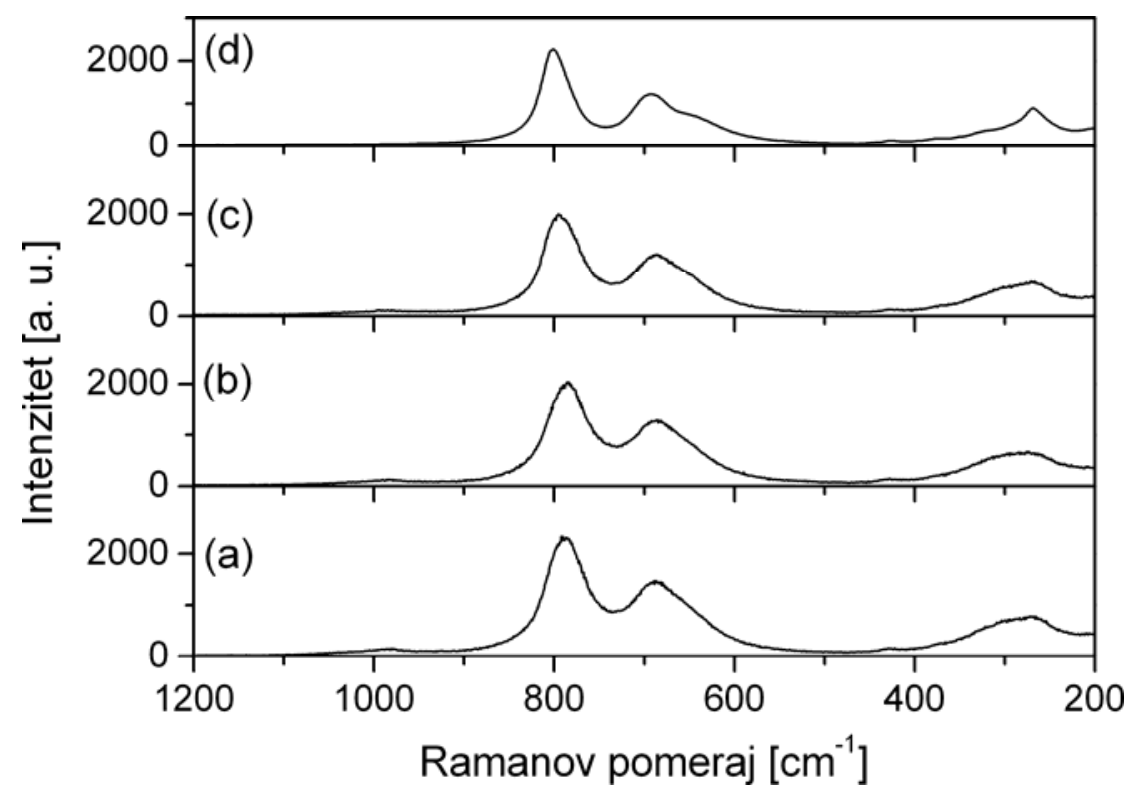

Slika 6.13. Ramanovi spektri: (a) spektar oksidnog sloja dobijen nakon $15 \mathrm{~min}$;

(b) spektar oksidnog sloja nakon 30 min; (c) spektar oksidnog sloja nakon 45 min PEO tretmana;

(d) referentni spektar uzorka WSiA nakon termalnog tretmana na $550{ }^{\circ} \mathrm{C}$. 
Ramanovi spektri oksidnih slojeva dobijenih u različitim fazama PEO procesa (SI. 6.13-a,b,c) su identični referentnom Ramanovom spektru WSiA izložene termalnom tretmanu na $550{ }^{\circ} \mathrm{C}$ (SI. 6.13-d). Ovo ukazuje da su se na površini tantala formirale volframske bronze. 


\section{PLAZMA ELEKTROLITIČKA OKSIDACIJA MAGNEZIJUMA AZ31}

Magnezijum i njegove legure pokazuju odlične fizičke i mehaničke osobine (veliku čvrstoću u poređenju sa težinom i gustinom), visoku toplotnu provodljivost, visoku dimenzionalnu stabilnost, dobre elektromagnetne zaštitne i visoke prigušne karakteristike. Pored toga, magnezijum i njegove legure se lako obrađuju i recikliraju [192-194].

Odnos čvrstoće prema težini čini ga idealnim metalom za primenu u automobilskoj i avio industiji, gde je upravo smanjenje težine metala ili legura jako značajno. Koristi se u izradi kompjuterskih komponenti, mobilnih telefona, prenosivih alata $\mathrm{i} u$ domaćinstvu. Magnezijum i njegove legure se koristi i kao implantanti zbog male težine i dobre biokompatibilnosti [195].

Na žalost, magnezijum i njegove legure su podložne koroziji [196]. Velika reaktivnost i mala koroziona otpornost ograničavaju primenu ovih materijala. Najlakši put da se spreči korozija magnezijuma je zaštita prevlačenjem oksidnim slojem. Time se sprečava direktan kontakt osnove metala i okoline. Povećanje korozione otpornosti magnezijuma i njegovih legura moguće je postići: elektrohemijskim postupcima prevlačenja, nanošenjem konverzionih prevlaka, anodizacijom, gasno-faznim depozicionim procesima, lasersko površinskim legiranjem, nanošenjem organskih prevlaka ili nanošenjem drugih vrsta prevlaka alternativnim postupcima [197-198]. U poslednje vreme kao jedan od najboljih postupaka za ovakvu vrstu tretmana na magnezijumu pokazala se PEO.

U ovom poglavlju, izložiće se rezultati istraživanja PEO procesa na leguri magnezijuma AZ31 u vodenom rastvoru koji se sastoji od $\mathrm{Na}_{2} \mathrm{SiO}_{3} \cdot 5 \mathrm{H}_{2} \mathrm{O}$ i $\mathrm{KOH}[199,200]$.

\subsection{Eksperimentalni podaci}

Oksidne površine su formirane na uzorcima magnezijumove legure AZ31 (96\% Mg, $3 \% \mathrm{Al}, 1 \% \mathrm{Zn}$, Goodfellow) dimenzija $25 \mathrm{~mm}$ x $5 \mathrm{~mm}$ x $0.25 \mathrm{~mm}$. Pre postupka anodizacije uzorci su odmašćeni u ultrazvučnoj kadi u acetonu, etanolu i destilovanoj vodi. Tako očišćeni uzorci, sušeni su u struji toplog vazduha i anodizirani u vodenom rastvoru koji se sastoji od 4 $\mathrm{g} / \mathrm{L} \mathrm{Na}_{2} \mathrm{SiO}_{3} \cdot 5 \mathrm{H}_{2} \mathrm{O}$ i $4 \mathrm{~g} / \mathrm{L} \mathrm{KOH}$. Anodizacija magnezijuma je vršena u elektrolitičkoj ćeliji u 
režimu konstantne gustine struje od $100 \mathrm{~mA} / \mathrm{cm}^{2}$. U toku anodizacije, temperatura elektrolita je održavana konstantnom $(21 \pm 1){ }^{\circ} \mathrm{C}$.

\subsection{Optička karakterizacija i analiza PEO procesa na magnezijumu AZ31 u realnom vremenu}

\subsubsection{Zavisnost napona $i$ intenziteta luminescencije od vremena anodizacije}

Na SI. 7.1 data je tipična zavisnost napona anodizacije i intenziteta luminescencije $u$ toku anodizacije magnezijuma. $U$ zavisnosti od trenda napona i intenziteta luminescencije $u$ toku anodizacije, jasno se mogu uočiti tri etape anodizacije.

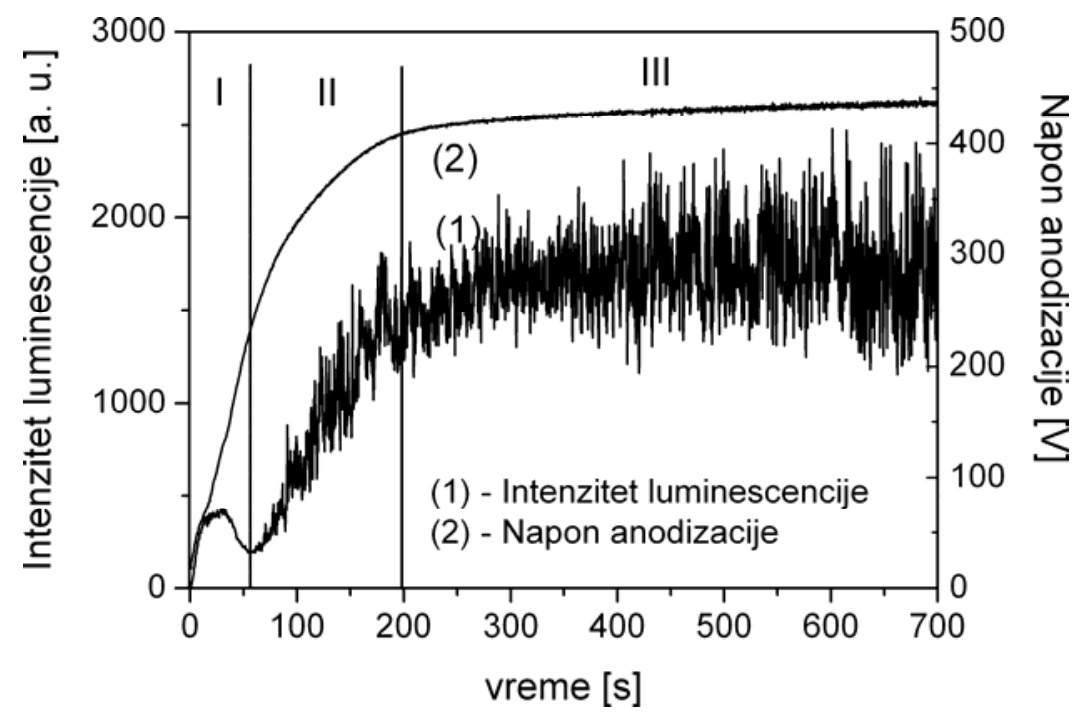

Slika 7.1. Zavisnost napona i intenziteta luminescencije od vremena anodizacije

$\mathrm{Na}$ samom početku procesa, napon anodizacije raste linearno sa vremenom do oko $230 \mathrm{~V}$, sa nagibom od $3.76 \mathrm{~V} / \mathrm{s}$. Rast napona anodizacije praćen je konstantnim rastom debljine oksidnog sloja. Istovremeno se javlja slaba anodna luminescencija (galvanoluminescencija). Dostizanjem napona proboja, naponska kriva počinje da lagano odstupa od linearnosti (oblast II na Sl. 7.1) i kao kod PEO procesa kod drugih ventilnih metala, javlja se veliki broj mikro pražnjenja ravnomerno raspoređenih po čitavoj površini uzorka. U ovoj etapi PEO procesa ne postoji potreba za tako visokim naponima kao u etapi I da bi se ukupna gustina struje održala konstantnom i samim tim je i nagib naponske krive u 
ovoj oblasti niži. Luminescenija mikro pražnjenja se kombinuje sa anodnom i ukupna luminescencija u toku PEO vremena raste. U završnoj fazi procesa (oblast III) na SI. 7.1 elektronska komponenta gustine struje postaje dominantna i skoro u potpunosti nezavisna od debljine oksidnog filma. U ovoj etapi, nagib naponske krive dostiže skoro nultu vrednost.

\subsubsection{Dinamika i distribucija mikro pražnjenja u toku PEO procesa}

Na Sl. 7.2 prikazana je pojava mikro pražnjenja u različitim etapama PEO procesa. Prva mikro pražnjenja se mogu uočiti na završetku etape I. Kao i u slučaju PEO procesa na aluminijumu, titanijumu i tantalu, veličina mikro pražnjenja raste, ali se njihov broj smanjuje sa vremenom.

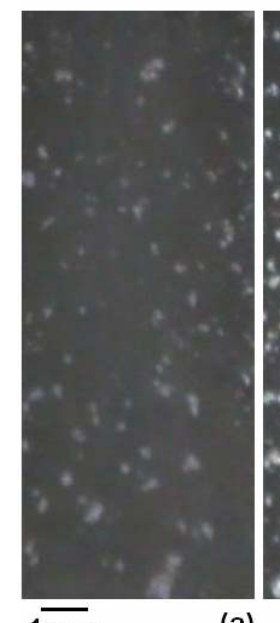

.$\overline{\mathrm{mm}}$

(a)

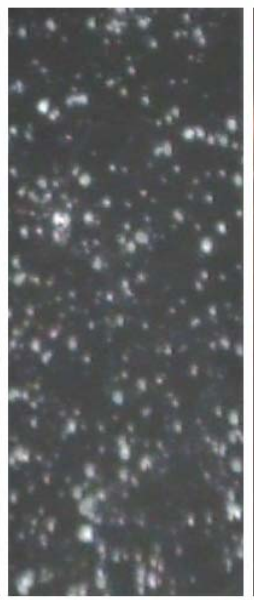

(b)

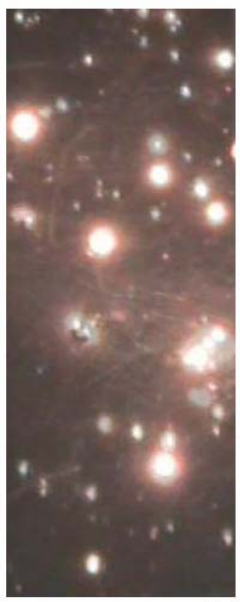

(c)

Slika 7.2. Pojava mikro pražnjenja u različitim etapama PEO procesa: (a) $5 \mathrm{~s}$; (b) $100 \mathrm{~s}$; (c) $200 \mathrm{~s}$.

Na SI. 7.3-a. pokazano je kako se menja prostorna gustina mikro pražnjenja u toku PEO procesa. Vidi se da je prostorna gustina mikro pražnjenja najveća $\sim 80$ s nakon početka PEO procesa, ali se u narednih 200 s značajno smanjuje i ostaje gotovo konstantna. Procenat oksidne površine istovremeno pokrivene aktivnim mestima za mikro pražnjenje, takođe je najveći posle $120 \mathrm{~s}$ od početka procesa ( 6\%) i zatim ostaje skoro konstantan (Sl. 7.3-b). 

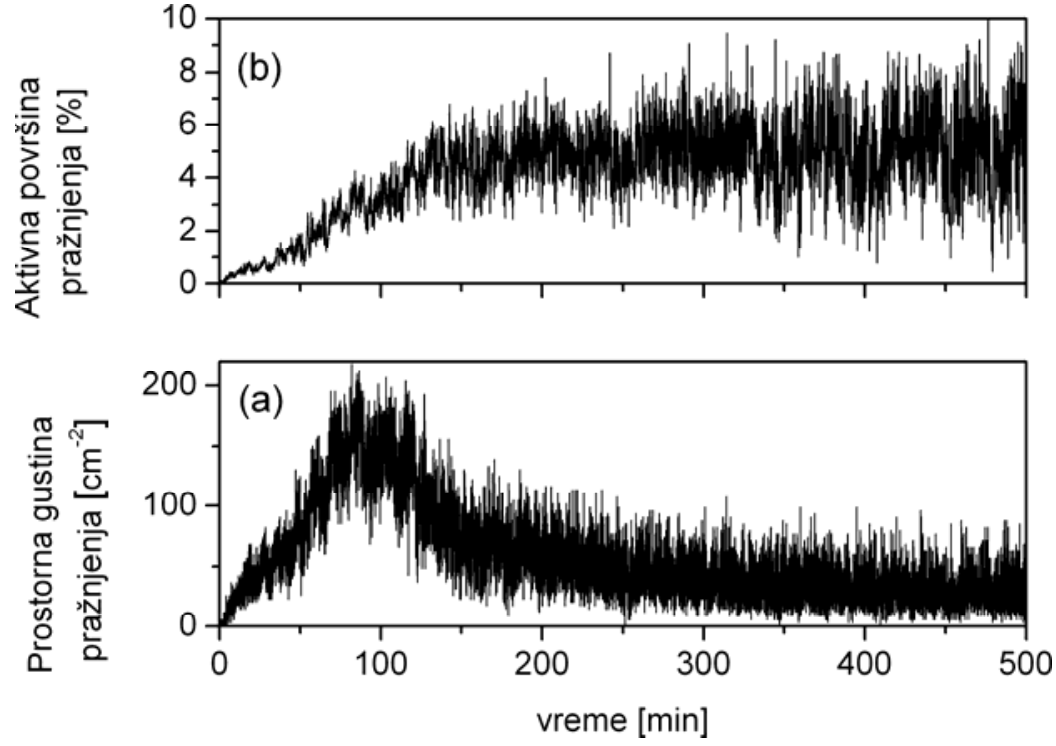

Slika 7.3. Karakteristike mikro pražnjenja u različitim etapama PEO procesa: (a) prostorna gustina mikro pražnjenja; (b) procenat oksidne površine istovremeno pokrivena aktivnim mestima za mikro pražnjenje.
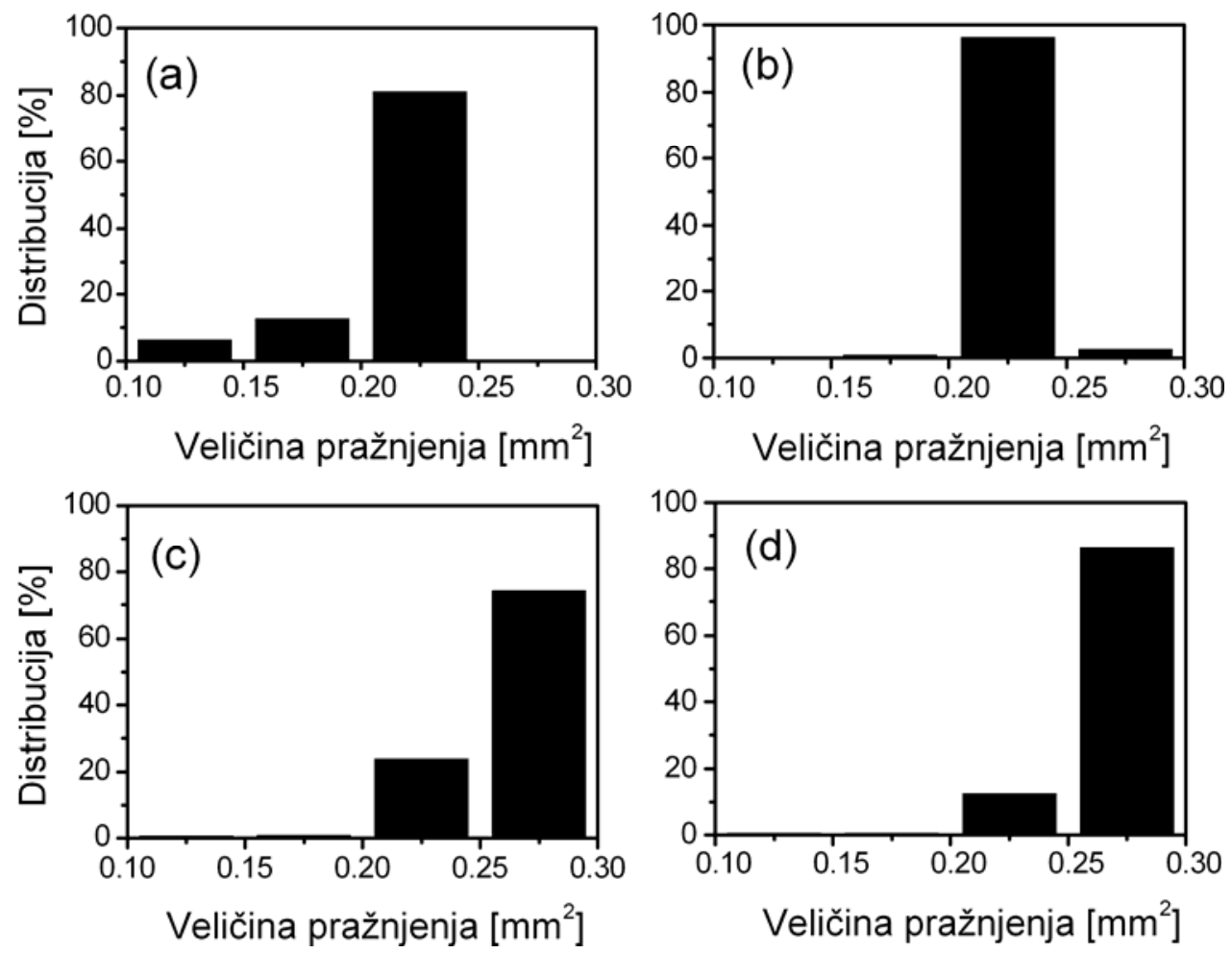

Slika 7.4. Dimenzionalna distribucija veličine mikro pražnjenja u različitim fazama PEO procesa: (a) $10 \mathrm{~s}$; (b) $80 \mathrm{~s}$; (c) $200 \mathrm{~s}$; (d) $300 \mathrm{~s}$. 
Dimenzionalna distribucija mikro pražnjenja data je na SI. 7.4. Mala mikro pražnjenja (površina poprečnog preseka $<0.15 \mathrm{~mm}^{2}$ ) javljaju se samo na početku procesa. Mikro pražnjenja srednje veličine (površina poprečnog preseka u rasponu od $0.15 \mathrm{~mm}^{2}$ do $0.25 \mathrm{~mm}^{2}$ ) prisutna su sve vreme anodizacije i njihova frakcija u odnosu na sva mikro pražnjenja dostiže skoro 100 \% nakon 80 s. Velika mikro pražnjenja (površina poprečnog preseka $>0.25$ ) postaju dominantna u daljim fazama PEO procesa, nakon $300 \mathrm{~s}$.

Morfologija površina oksidnih slojeva na magnezijumu dobijenih $\mathrm{u}$ različitim etapama PEO procesa je prikazana na SI. 7.5. Na početku anodizacije, sa linearnim porastom napona formira se relativno kompaktan barijerni oksidni sloj (Sl. 7.5-a). Površine uzoraka snimljene nakon proboja pokazuju veliki broj pukotina, pora i kanala (SI. 7.5-b,c). Porast veličine mikro pražnjenja je posledica redukovanja mesta za proboj kroz koje sada prolazi veća gustina struje. Morfologija površina oksidnih slojeva formiranih na magnezijumu jasno pokazuje da se broj mikro pora smanjuje, a njihova veličina raste tokom PEO procesa.

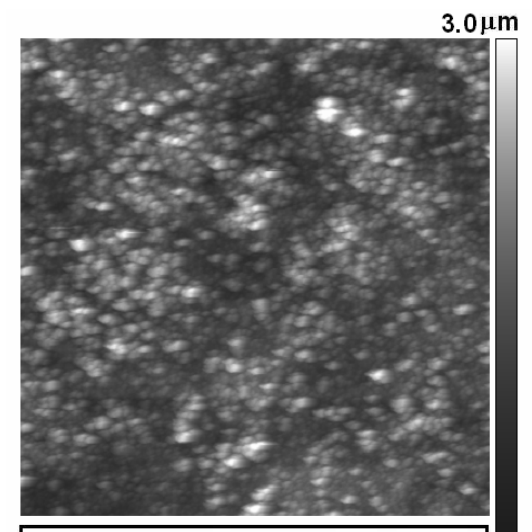

0.0

(a)

$60.0 \mu \mathrm{m}=0.0$

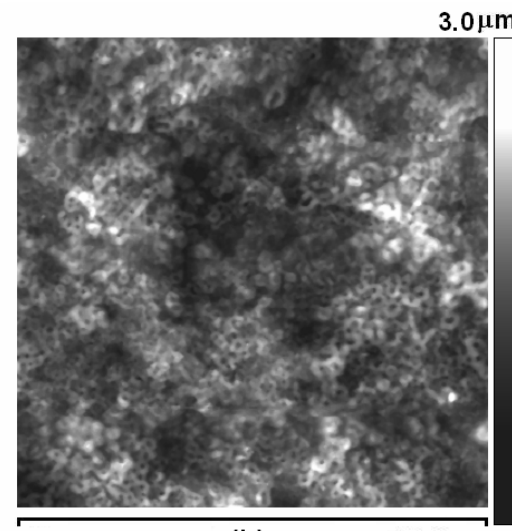

(b)

$60.0 \mu \mathrm{m}$

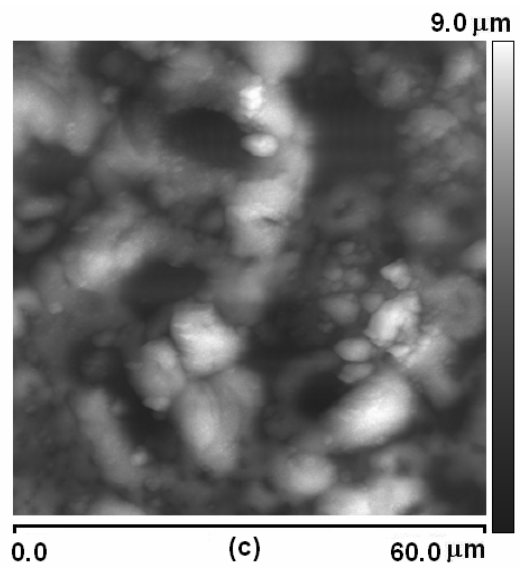

Slika 7.5. AFM slike površina oksidnih slojeva na magnezijumu u različitim etapama PEO procesa: (a) pre pojave prvih mikro pražnjenja (150 V); (b) pri naponu od $350 \mathrm{~V}$; (c) 4 min nakon počeka PEO procesa.

\subsubsection{Spektralna karakterizacija PEO procesa}

Tipičan emisioni spektar mikro pražnjenja tokom PEO procesa na magnezijumu, $u$ spektralnom opsegu od $370 \mathrm{~nm}$ do $850 \mathrm{~nm}$ je prikazan na SI. 7.6-a. Detaljniji emisioni spektar u opsegu od $380 \mathrm{~nm}$ do $510 \mathrm{~nm}$ prikazan na Sl. 7.6-b. Jasno definisane spektralne linije ukazuju na postojanje elektronskih prelaza. Za identifikaciju atomskih i jonskih linija 
korišćena je NIST-ova baza podataka. Sve identifikovane jonske i atomske linije u spektru potiču ili iz elektrolita ili od same magnezijumove legure.
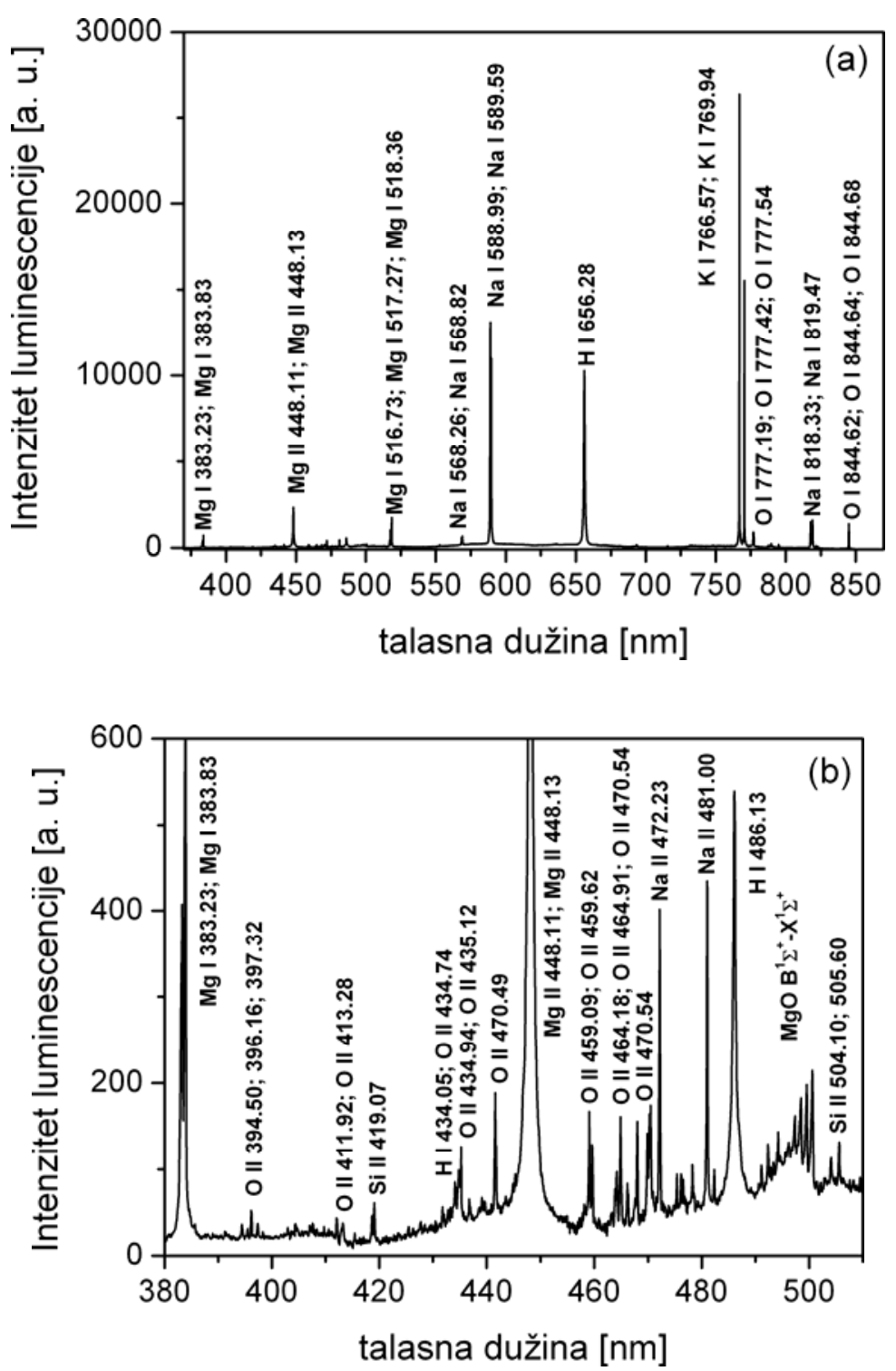

Slika 7.6. Optičko emisioni spektar dobijen u toku PEO procesa u opsegu talasnih dužina:

(a) $370 \mathrm{~nm}-850 \mathrm{~nm}$; (b) $380 \mathrm{~nm}-510 \mathrm{~nm}$.

Najjače linije su atomske linije K I na $766.57 \mathrm{~nm}$ i $769.94 \mathrm{~nm}$, Na I na $588.99 \mathrm{~nm}$ i $589.59 \mathrm{~nm}$, Balmerova $\mathrm{H}_{\alpha}$ na 656, $28 \mathrm{~nm}$, jonske linije $\mathrm{Mg}$ II na $448.11 \mathrm{~nm}$ i $448.13 \mathrm{~nm}$ i Mg I na $516.73 \mathrm{~nm}, 517.27 \mathrm{~nm}$ i $518.36 \mathrm{~nm}$. U spektru se primećuju i linije kiseonika, O I na $777.19 \mathrm{~nm}, 777.42 \mathrm{~nm}$ i $777.54 \mathrm{~nm}$, tri na $844.62 \mathrm{~nm}, 844.64 \mathrm{~nm}$ i $844.66 \mathrm{~nm}$, zatim Na I na 818.33 i $819.47 \mathrm{~nm}, \mathrm{Mg}$ I na $383.23 \mathrm{~nm}$ i $383.83 \mathrm{~nm}$. Emisioni spektar u oblasti talasnih 
dužina od $380 \mathrm{~nm}$ do $510 \mathrm{~nm}$ ukazije na prisustvo Balmerovih linija vodonika, $\mathrm{H}_{\beta}$ (486.13 nm) i $\mathrm{H}_{\gamma}(434.05 \mathrm{~nm})$, slabijih linija O II, Si II i Na II. Pored jasno izraženih atomskih i jonskih linija, u opsegu talasnih dužina od $490 \mathrm{~nm}$ do $501 \mathrm{~nm}$, jasno je vidljiva i traka $\mathrm{MgO}$ koja odgovara prelazu sa pobuđenog $\mathrm{B}^{1} \Sigma^{+}$nivoa na osnovni $\mathrm{X}^{1} \Sigma^{+}$. Luminescentni spektar prelaza $\mathrm{B}^{1} \Sigma^{+}-\mathrm{X}^{1} \Sigma^{+}$molekula MgO sa pridruženim trakama, predstavljen je na Sl. 7.7 [12].

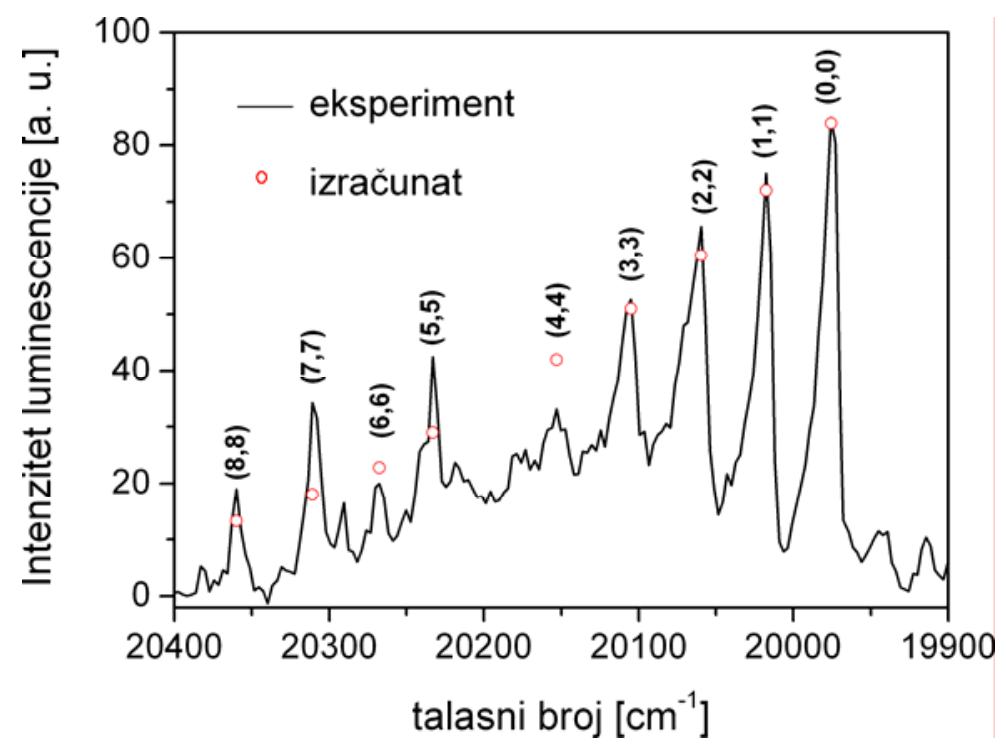

Slika 7.7. Luminescentni spektar između $19950 \mathrm{~cm}^{-1}$ i $20400 \mathrm{~cm}^{-1}$, trake $\left(v^{\prime}, v^{\prime \prime}\right)$ prelaza $\mathrm{B}^{1} \Sigma^{+}-\mathrm{X}^{1} \Sigma^{+}$sistema MgO. Kružići predstavljaju maksimume dobijene računskim putem.

U Tabeli 7.1 su predstavljene eksperimentalne i izračunate vrednosti termova za elektronski prelaz $\mathrm{B}^{1} \Sigma^{+}-\mathrm{X}^{1} \Sigma^{+}$sistema $\mathrm{MgO}$ dobijene od strane različitih istraživačkih grupa uključujući i naše rezultate .

Druga kolona Tabele 7.1 (Exp. 1) predstavlja eksperimentalne podatke prelaza $v^{\prime}-v^{\prime \prime}=0$ dobijene od strane Ghosh-a [201] i saradnika. Relativne vrednosti termova u odnosu na položaj trake (0-0) date su u zagradi ispod apsolutne vrednosti $\mathrm{u} \mathrm{cm}^{-1}$. Ova grupa istraživača predlaže sledeću formulu za računanje vrha trake:

$$
\widetilde{v}_{h}=19967+\left(751 v^{\prime}-3.06 v^{\prime 2}\right)-\left(716 v^{\prime \prime}-5.96 v^{\prime \prime 2}\right),
$$

koja se u slučaju $v^{\prime}-v^{\prime \prime}=0$ :

$$
\widetilde{v}_{h}=19967+35 v+2.9 v^{2}
$$


Uz primenu odgovarajućeg fitovanja dobijene su vrednosti u koloni Fit 1. Poređenjem sa eksperimentalnim podacima iz kolone Exp. 1 uočava se dobro slaganje jedino trake 4-4.

Eksperimentalni podaci Lagerqvist-a [202] i Pešića [203] prikazani su u kolonama Exp. 2 i Exp. 3, dok su rezultati Pearse i Gaydon [204] dati u koloni Exp. 4.

Pešić uspešno uzima u obzir korekciju u odnosu na vrh trake i za izračunavanje termova koristi formulu:

$$
\widetilde{v}_{0}=19983.97+\left[796.08\left(v^{\prime}+\frac{1}{2}\right)-4.44\left(v^{\prime}+\frac{1}{2}\right)^{2}\right]-\left[758.38\left(v^{\prime \prime}+\frac{1}{2}\right)-4.84\left(v^{\prime \prime}+\frac{1}{2}\right)^{2}\right]
$$

koja za prelaz $v^{\prime}=v^{\prime \prime} \equiv v$ postaje:

$$
\widetilde{v}_{0}=20003.6+38.09 v+0.39 v^{2}
$$

Ova formula se ne pokazuje dobro za trake $v^{\prime}=v^{\prime \prime} \geq 5$, termovi izračunati ovom formulom ne pokazuju dovoljno sličnosti sa eksperimentalnim vrednostima Exp. 1 i Exp. 2.

Formula koja se najčešće koristi za izračunavanja vibracionih termova data je od strane Huber-a i Herzberg-a [205]:

$$
\begin{aligned}
& \widetilde{v}_{0}\left(X^{2} \Sigma^{+}\right)=785.06\left(v^{\prime \prime}+\frac{1}{2}\right)-5.18\left(v^{\prime \prime}+\frac{1}{2}\right)^{2}, \\
& \widetilde{v}_{0}\left(B^{2} \Sigma^{+}\right)=19984.0+824.08\left(v^{\prime}+\frac{1}{2}\right)-4.76\left(v^{\prime}+\frac{1}{2}\right)^{2} .
\end{aligned}
$$

koja za prelaz $v^{\prime}-v^{\prime \prime}=0$ postaje:

$$
\widetilde{v}_{0}\left(B^{2} \Sigma^{+}\right)-\widetilde{v}_{0}\left(X^{2} \Sigma^{+}\right)=20003.6+39.44 v+0.42 v^{2} .
$$

Termovi izračunati na ovaj način dati su u koloni Fit 4. Iako se formula (7.5) pokazala pouzdanija u postupku proračuna termova od formula (7.1) i (7.3), jer uzima u obzir korekcije vibracionih frekvencija, nju je nemoguće uspešno koristiti za računanje pozicija $v^{\prime}-v^{\prime \prime}>4$. 
Tabela 7.1. Pozicije $v^{\prime}-v^{\prime \prime}=0$ traka $\left(\mathrm{cm}^{-1}\right)$ prelaza $\mathrm{B}^{1} \Sigma^{+}-\mathrm{X}^{1} \Sigma^{+}$za MgO. (a-Ref. [201], b-Ref. [202], c-Ref. [206], d-Ref. [204], e-Ref [199]., f-Ref. [206])

\begin{tabular}{|c|c|c|c|c|c|c|c|c|c|c|}
\hline$v^{\prime}-v^{\prime \prime}$ & $\begin{array}{c}\operatorname{Exp} 1^{\mathrm{a}} \\
\widetilde{v}_{h}\end{array}$ & $\begin{array}{c}\operatorname{Exp} .2^{b} \\
\widetilde{v}_{h}\end{array}$ & $\begin{array}{c}\operatorname{Exp} .3^{\mathrm{c}} \\
\widetilde{v}_{h}\end{array}$ & $\begin{array}{c}\operatorname{Exp} .4^{\mathrm{d}} \\
\widetilde{v}_{h}\end{array}$ & $\begin{array}{c}\operatorname{Exp} .5^{\mathrm{e}} \\
\widetilde{v}_{h}\end{array}$ & $\begin{array}{c}\text { Fit } 1^{\mathrm{a}} \\
\widetilde{v}_{h}\end{array}$ & $\begin{array}{c}\text { Fit } 2^{\mathrm{c}} \\
\tilde{v}_{h}\end{array}$ & $\begin{array}{c}\text { Fit } 3^{\mathrm{c}} \\
\widetilde{v}_{0}\end{array}$ & $\begin{array}{c}\text { Fit } 4^{\mathrm{f}} \\
\widetilde{v}_{0}\end{array}$ & $\begin{array}{c}\text { Fit } 5^{\mathrm{e}} \\
\widetilde{v}_{0}\end{array}$ \\
\hline $0-0$ & $\begin{array}{r}19966 \\
(0)\end{array}$ & $\begin{array}{r}19965 \\
(0)\end{array}$ & $\begin{array}{r}19967 \\
(0)\end{array}$ & $\begin{array}{r}19971 \\
(0)\end{array}$ & $\begin{array}{r}19976 \\
(0)\end{array}$ & $\begin{array}{r}19967 \\
(0)\end{array}$ & $\begin{array}{r}19966 \\
(0)\end{array}$ & $\begin{array}{r}20003 \\
(0)\end{array}$ & $\begin{array}{r}20004 \\
(0)\end{array}$ & $\begin{array}{r}20004 \\
(0)\end{array}$ \\
\hline $1-1$ & $\begin{array}{r}20007 \\
(41)\end{array}$ & $\begin{array}{r}20007 \\
(42)\end{array}$ & $\begin{array}{r}20008 \\
(41)\end{array}$ & $\begin{array}{r}20013 \\
(42)\end{array}$ & $\begin{array}{r}20018 \\
(42)\end{array}$ & $\begin{array}{r}20005 \\
(38)\end{array}$ & $\begin{array}{r}20008 \\
(41)\end{array}$ & $\begin{array}{r}20241 \\
(38)\end{array}$ & $\begin{array}{r}20044 \\
(40)\end{array}$ & $\begin{array}{r}20044 \\
\quad(40)\end{array}$ \\
\hline $2-2$ & $\begin{array}{r}20049 \\
(83)\end{array}$ & $\begin{array}{r}20051 \\
\quad(86)\end{array}$ & $\begin{array}{r}20049 \\
(82)\end{array}$ & $\begin{array}{r}20057 \\
(86)\end{array}$ & $\begin{array}{r}20060 \\
(84)\end{array}$ & $\begin{array}{r}20049 \\
(82)\end{array}$ & $\begin{array}{r}20049 \\
(83)\end{array}$ & $\begin{array}{r}20081 \\
(78)\end{array}$ & $\begin{array}{r}20084 \\
(81)\end{array}$ & $\begin{array}{r}20084 \\
\quad(81)\end{array}$ \\
\hline $3-3$ & $\begin{array}{r}20093 \\
(127)\end{array}$ & $\begin{array}{r}20097 \\
(132)\end{array}$ & $\begin{array}{r}20092 \\
(125)\end{array}$ & $\begin{array}{r}20103 \\
(132)\end{array}$ & $\begin{array}{r}20106 \\
(130)\end{array}$ & $\begin{array}{c}20098 \\
(131)\end{array}$ & $\begin{array}{r}20092 \\
(125)\end{array}$ & $\begin{array}{r}20121 \\
(118)\end{array}$ & $\begin{array}{r}20126 \\
(122)\end{array}$ & $\begin{array}{r}20127 \\
(123)\end{array}$ \\
\hline $4-4$ & $\begin{array}{r}20146 \\
(180)\end{array}$ & & $\begin{array}{r}20137 \\
(170)\end{array}$ & $\begin{array}{r}20153 \\
(182)\end{array}$ & $\begin{array}{r}20153 \\
(177)\end{array}$ & $\begin{array}{r}20153 \\
(186)\end{array}$ & $\begin{array}{r}20134 \\
(168)\end{array}$ & $\begin{array}{r}20162 \\
(159)\end{array}$ & $\begin{array}{r}20168 \\
(164)\end{array}$ & $\begin{array}{r}20171 \\
(167)\end{array}$ \\
\hline $5-5$ & $\begin{array}{r}20200 \\
(234)\end{array}$ & & & $\begin{array}{r}20204 \\
(233)\end{array}$ & $\begin{array}{r}20231 \\
(255)\end{array}$ & $\begin{array}{r}20215 \\
(248)\end{array}$ & & $\begin{array}{r}20203 \\
(200)\end{array}$ & $\begin{array}{r}20211 \\
(208)\end{array}$ & $\begin{array}{r}20216 \\
(213)\end{array}$ \\
\hline $6-6$ & $\begin{array}{r}20257 \\
(291)\end{array}$ & & & $\begin{array}{c}20262 \\
(291)\end{array}$ & $\begin{array}{r}20268 \\
(292)\end{array}$ & $\begin{array}{r}20281 \\
(314)\end{array}$ & & $\begin{array}{r}20245 \\
(243)\end{array}$ & $\begin{array}{r}20255 \\
(252)\end{array}$ & $\begin{array}{r}20265 \\
(261)\end{array}$ \\
\hline $7-7$ & $\begin{array}{r}20304 \\
(338)\end{array}$ & & & $\begin{array}{r}20309 \\
(338)\end{array}$ & $\begin{array}{r}20310 \\
(334)\end{array}$ & $\begin{array}{r}20354 \\
(387)\end{array}$ & & $\begin{array}{r}20289 \\
(286)\end{array}$ & $\begin{array}{r}20300 \\
(297)\end{array}$ & $\begin{array}{r}20316 \\
(312)\end{array}$ \\
\hline $8-8$ & $\begin{array}{r}20347 \\
(381)\end{array}$ & & & & $\begin{array}{r}20360 \\
(384)\end{array}$ & $\begin{array}{r}20433 \\
(466)\end{array}$ & & $\begin{array}{r}20333 \\
(330)\end{array}$ & $\begin{array}{r}20346 \\
(342)\end{array}$ & $\begin{array}{r}20372 \\
(368)\end{array}$ \\
\hline $9-9$ & $\begin{array}{r}20388 \\
(422)\end{array}$ & & & & & $\begin{array}{r}20517 \\
(550)\end{array}$ & & $\begin{array}{r}20377 \\
(374)\end{array}$ & $\begin{array}{r}20393 \\
(389)\end{array}$ & $\begin{array}{r}20434 \\
(430)\end{array}$ \\
\hline
\end{tabular}

Zaključak je da nijedna od ovih formula ne može u potpunosti reprodukovati eksperimentalne rezultate za veće vrednosti $v$ jer razlika u talasnim brojevima sukcesivnih 
traka prati kvadripolnu zavisnost samo u slučaju prvih nekoliko termova. U skladu sa tim, naši rezlutati u koloni Exp. 5. su dati sa tačnošću $\pm 5 \mathrm{~cm}^{-1}$.

Složen kvantno-mehanički i termodinamički aparat primenjen u analizi MgO trake $\mathrm{B}^{1} \Sigma^{+}-\mathrm{X}^{1} \Sigma^{+}$, uz izmerenu distribuciju intenziteta, omogućava dobru procenu populacije nižih vibracionih nivoa $\mathrm{i}$ viših elektronskih stanja, a iz toga i procenu temperature plazme uz pretpostavljenu lokalnu termodinamičku ravnotežu za sve stepene slobode [199]. Iz procenjene naseljenosti vibracionih nivoa $\mathrm{B}^{1} \mathrm{X}^{+}$sistema $\mathrm{MgO}$ za prelaze $(0-0),(1-1),(2-2) \mathrm{i}$ (3-3), uz pretpostavku termalne ravnoteže procenjene su temperature $11000 \mathrm{~K} \pm 2000 \mathrm{~K}$ [199], nešto više nego za AlO sistem (8000 K $\pm 2000 \mathrm{~K})$ [110].

Postavlja se pitanje, da li je emisioni spektar $\mathrm{MgO}$ vrste, iz čijih je intenziteta procenjena temperatura plazme od $11000 \mathrm{~K}$ moguće dobiti na toj temperaturi, tj. da li je populacija $\mathrm{MgO}$ vrsta u pobuđenom stanju dovoljna da se detektuje taj spektar. U tom cilju, pretpostavljeno je stanje lokalne termodinamičke ravnoteže i sastav plazme od $\mathrm{Mg}: \mathrm{O}: \mathrm{H} \mathrm{u}$ odnosu $1: 1: 1$. Za temperature do $12000 \mathrm{~K}$ i pritiske od $10^{5,} 10^{6}, 10^{7}$ i $10^{8}$ i računat je sastav plazme. Pošto je ovaj odnos samo pretpostavljen, radi poređenja, isti sastav je računat i za odnose pomenutih vrsta: 1:1:0, 0:1:1 i 0:1:2 kako bi se procenio uticaj izbora na konačan rezultat. SI. 7.8 pokazuje rezultat jednog takvog složenog proračuna za odnos $\mathrm{Mg}: \mathrm{O}, 1: 1$ i različite pritiske [199].

Na Sl. 7.8-a su predstavljeni rezultati za pritiske od $10^{5} \mathrm{~Pa}$. Na temperaturama oko $11000 \mathrm{~K}$, parcijalni pritisak $\mathrm{MgO}$ je otprilike $1 / 10^{5}$ od ukupnog pritiska i to nije dovoljno za detekciju $\mathrm{MgO}$ u emisionom spektru. $\mathrm{Na}$ ovim temperaturama i pritiscima, oko 90\% magnezijuma je u formi $\mathrm{Mg}^{+}$i $10 \%$ kao atomski $\mathrm{Mg}$. Na nešto nižim temperaturama oko $9000 \mathrm{~K}$ parcijalni pritisti $\mathrm{Mg}$ i $\mathrm{Mg}^{+}$postaju jednaki, a na nižim temperaturama atomski $\mathrm{Mg}$ je dominantna forma magnezijuma.

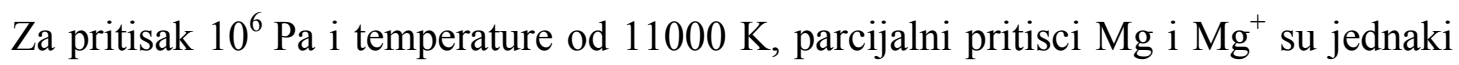
(Sl.7.8-b). Na temperaturama nižim od $11000 \mathrm{~K}$ u sastavu plazme dominira Mg, a iznad $11000 \mathrm{~K} \mathrm{Mg}^{+}$. Viši pritisci (u odnosu na $10^{5} \mathrm{~Pa}$ ) favorizuju građenje $\mathrm{MgO}$, i na $11000 \mathrm{~K}$ otprilike $0.1 \%$ magnezijuma je u formi $\mathrm{MgO}$. Na pritisku od $10^{7} \mathrm{~Pa}$ i temperaturi od $11000 \mathrm{~K}$ otprilike $2 \% \mathrm{Mg}$ nalazi u formi $\mathrm{MgO}$ (SI. 7.8-c). Parcijalni pritisak $\mathrm{Mg}^{+}$jona kao i elektrona se u tom slučaju smanjuju zahvaljujući pomeranju ravnoteže reakcije jonizacije ulevo, $\mathrm{Mg} \rightarrow \mathrm{Mg}^{+}+\mathrm{e}^{-}$. Pri pritiscima od $10^{8} \mathrm{~Pa}$ i temperaturama od $11000 \mathrm{~K}$ parcijalni pritisak $\mathrm{MgO}$ 
vrste premašuje parcijalni pritisak jona $\mathrm{Mg}^{+}$i za faktor četiri niži od parcijalnog pritiska najzastupljenije vrste, atomskog $\mathrm{Mg}$ (Sl. 7.8-d).
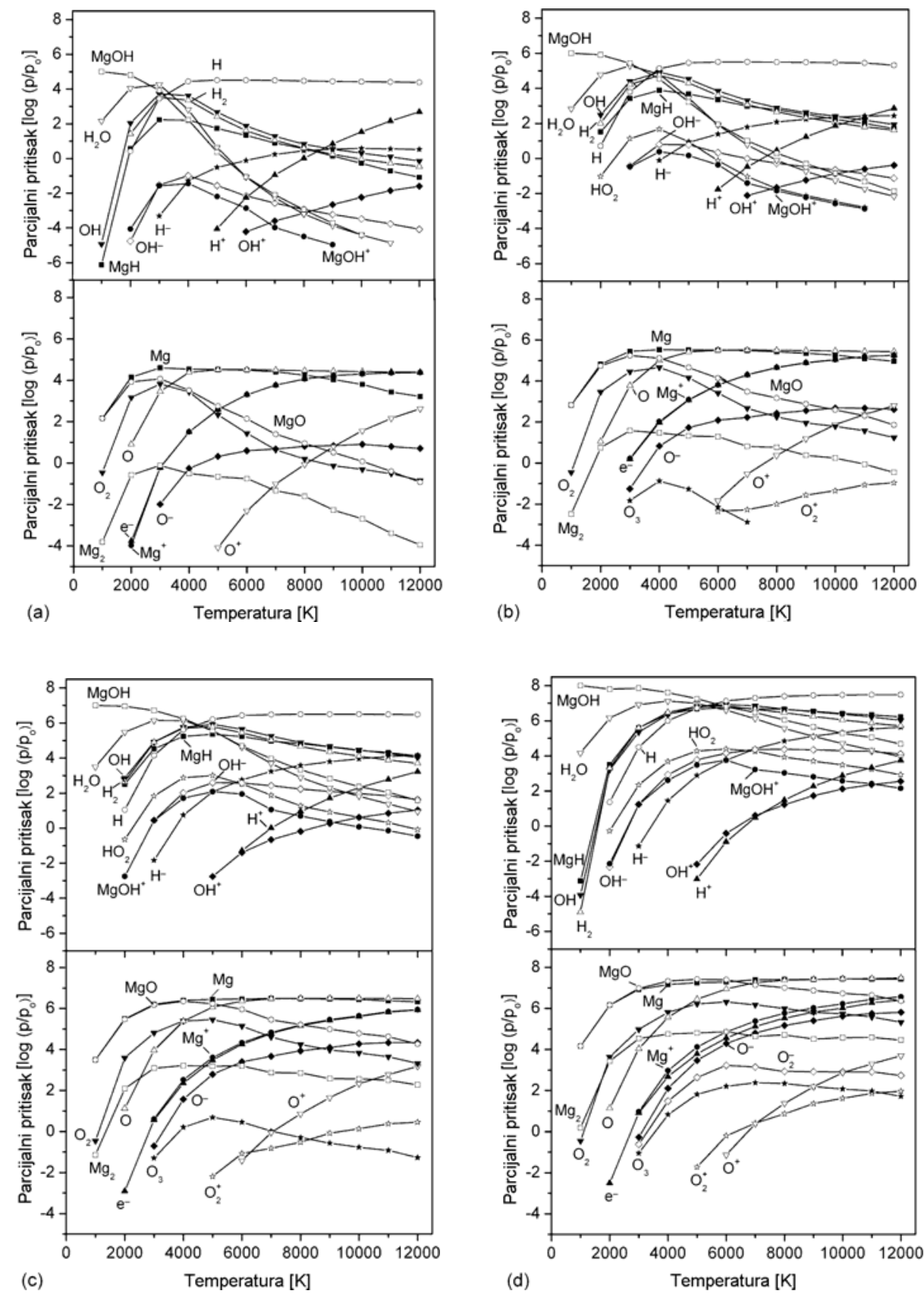

Slika 7.8. Ravnotežni sastav plazme koja sadrži magnezijum i kiseonik u molskom odnosu 1:1. $\mathrm{p}_{0}=10^{5} \mathrm{~Pa}$. (6a) $\mathrm{p}=10^{5} \mathrm{~Pa} ;(6 \mathrm{~b}) \mathrm{p}=10^{6} \mathrm{~Pa} ;(6 \mathrm{c}) \mathrm{p}=10^{7} \mathrm{~Pa} ;(6 \mathrm{~d}) \mathrm{p}=10^{8} \mathrm{~Pa}$

Naši rezultati pokazuju da je populacija $\mathrm{B}^{1} \Sigma^{+}$elektronskog stanja $\mathrm{MgO} 7 \% \mathrm{u}$ poređenju sa osnovnim što jeste dovoljno za pojavu emisionog spektra. 
Temperaturu plazme u toku PEO procesa je moguće proceniti iz OH traka. Na SI.7.9 prikazan je luminescentni spektar $u$ opsegu od $31000 \mathrm{~cm}^{-1}$ do $33000 \mathrm{~cm}^{-1}$ osnovnog prelaza $\mathrm{A}^{2} \Sigma^{+}-\mathrm{X}^{2} \Pi$ od $\mathrm{OH}$ sa nerazloženim rotacionim linijama na $32364 \mathrm{~cm}^{-1}, 32484 \mathrm{~cm}^{-1}$, $32597 \mathrm{~cm}^{-1}$ i $32622 \mathrm{~cm}^{-1}$. Primenjujući postupak Izarra-e [207], procenjena je temperatura $3500 \mathrm{~K} \pm 500 \mathrm{~K}$.

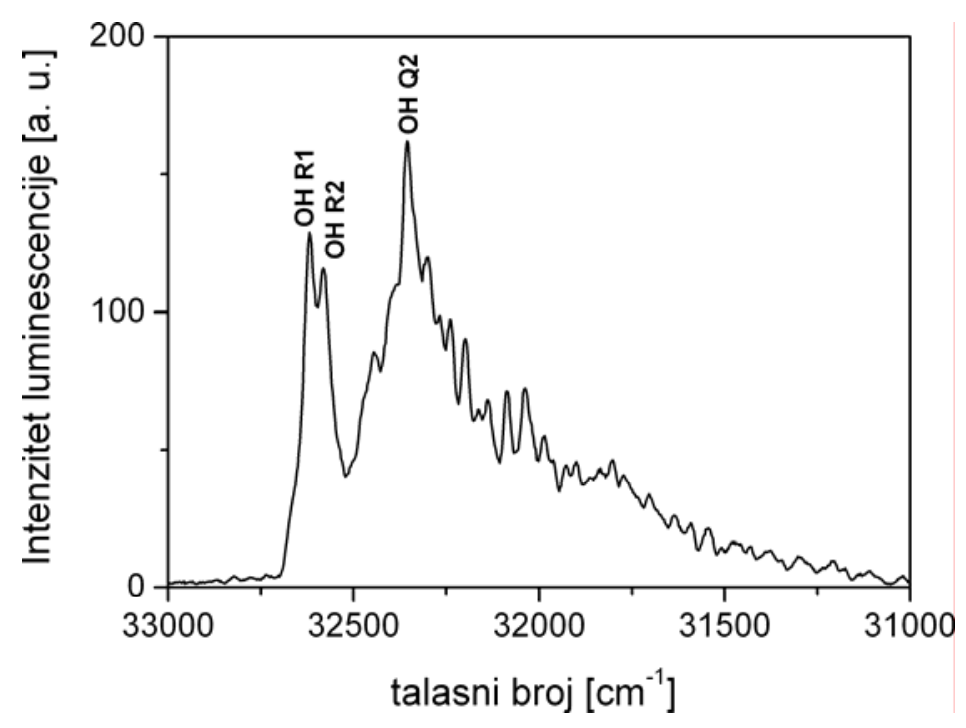

Slika 7.9. $A^{2} \Sigma^{+}\left(v^{\prime}=0\right)-X^{2} \Pi\left(v^{\prime \prime}=0\right)$ luminescentni spektar $\mathrm{OH}$ između $31000 \mathrm{~cm}^{-1}$ i $33000 \mathrm{~cm}^{-1}$

Razlika između rezultata dobijenih iz razrešene strukture $\mathrm{MgO}$ trake i nedefinisane strukture $\mathrm{OH}$ trake mogu se objasniti uzimanjem u obzir više različitih faktora. U prvom slučaju govorimo o vibracionoj temperaturi a u drugom o rotacionoj i moguće je da ova dva modela nisu u međusobnoj ravnoteži. Prema M.D. Klapkiv-u i saradnicima [98], kanali za plazma pražnjenja se sastoje od centralne zone sa temperaturama oko $7000 \mathrm{~K}$ i periferne zone sa nižim temperaurama. C.S. Dunleavy i saradnici [97] su procenili temperaturu periferne zone poređenjem intenziteta $\mathrm{H}_{\alpha}$ i $\mathrm{H}_{\beta}$ linije na $3500 \mathrm{~K}$, dok su jonske linije $\mathrm{Mg}^{+}$i Si ${ }^{+}$koristili za procenu temperature vrelog jezgra plazme i došli do podatka $16000 \mathrm{~K} \pm 3500 \mathrm{~K}$. Elektronsku gustinu vrelog jezgra procenili su na osnovu širenja $\mathrm{Mg}^{+} \mathrm{i} \mathrm{Si}^{+}$linija i došli do vrednosti od $\sim 5 \cdot 10^{17} \mathrm{~cm}^{-1}$, a za hladniji periferni sloj $\sim 10^{15} \mathrm{~cm}^{-1}$ i došli do zaključka da se lokalna termodinamička ravnoteža ostvaruje jedino u vrelom jezgru, dok je hladnija okolina u stanju parcijane termodinamičke ravnoteže. Ovo ukazuje da se $\mathrm{OH}$ molekuli formiraju i egzistiraju u hladnijem, perifernom regionu plazme [199]. 


\section{ZAKLJUČAK}

Plazma elektolitička oksidacija je obećavajuća tehnologija budućnosti za proizvodnju oksidnih površina na metalima sa izvanrednim hemijskim i mehaničkim osobinama. Oksidne površine pokazuju odličnu otpornost na habanje, trenje, koroziju, izvanredne termičke i električne osobine itd. PEO tehnika ne zahteva velika finansijska ulaganja, ne zagađuje okolinu i može se primeniti na jako velikom broju metala i njihovih legura. Osobine oksidnih površina dobijenih PEO procesom pre svega zavise od vrste izabranog metala i elektrolita. Ova doktorska disertacija daje nove informacije o procesima mikro pražnjenja i osobinama oksidnih slojeva dobijenih u toku PEO procesa na ventilnim metalima: aluminijumu, titanijumu, tantalu i magnezijumu. Važno je napomenuti i da se u ovoj disertaciji, po prvi put $\mathrm{u}$ do sada poznatoj literaturi, ispituje PEO u heteropoli kiselinama koje sadrže volfram, silicijum i fosfor (volframsilicijumska kiselina - WSiA i volframfosforna kiselina - WPA). Spoljašnji deo oksidnih slojeva formiranih pod ovim uslovima sadrži visok procenat bronzi koje su poznate po odličnim katalitičkim, poluprovodnim i antikorozivnim osobinama.

Neposredni rezulati istraživačkog rada predstavljenog u ovoj disertaciji su:

- Praćenjem zavisnosti napona anodizacije od vremena, jasno se u slučaju svih ispitivanih ventilnih metala, izdvajaju tri etape. $\mathrm{Na}$ samom početku, napon anodizacije linearno raste $\mathrm{i}$ sistem se ponaša u sladu sa Omovim zakonom. Dostizanjem kritičnog napona, na površini uzorka se javljaju prva varnična pražnjenja i naponska kriva odstupa od linearnosti. U ovoj etapi procesa jonska struja je za nekoliko redova veličina veća od elektronske komponente. Kritični napon anodizacije zavisi od uslova anodizacije (temperature i vrste elektrolita, gustine struje anodizacije i izabranog metala). U slučaju anodizacije aluminijuma u 0.001 M rastvoru WSiA ovaj napon iznosi $\sim 500 \mathrm{~V}$, titanijuma i tantala $\sim 420 \mathrm{~V}$, dok je u slučaju manezijuma u rastvoru $\mathrm{Na}_{2} \mathrm{SiO}_{3} \cdot 5 \mathrm{H}_{2} \mathrm{O}$ i $\mathrm{KOH}$ vrednost napona $\sim 230 \mathrm{~V}$. U završnim fazama procesa, doprinos elektronske struje ukupnoj gustini je daleko veći od jonske i nagib naponske krive se približava nultoj vrednosti.

- Početak anodizacije aluminijuma i magnezijuma je praćem slabom anodnom luminescencijom. Intenzitet luminescencije raste kvazi-eksponencijalno sa 
naponom anodizacije, odnosno vremenom anodizacije. Postizanjem kritičnog napona anodizicije, na anodnu luminescenciju se superpornira svetlosni intenzitet izazvan mikro pražnjenjima i ukupan intenzitet luminescencije raste. $\mathrm{U}$ toku anodizacije tantala i titanijuma nije zapažena anodna luminescencija.

- PEO procesi na svim ispitivanim metalima pokazuju tendenciju da se broj mikro pražnjenja smanjuje sa vremenom, a da površine poprečnih preseka mikro pražnjenja rastu. Mikro pražnjenja se, u toku PEO procesa, generišu prilikom proboja na takozvanim "slabim mestima" na površini uzorka. Na slabim mestima je otpor kretanju elektrona manji i stuja pronalazi svoj put kroz oksidni sloj. Broj slabih mesta se u toku PEO procesa smanjuje, te se prolaz iste gustine struje tada lokalizuje na preostalim slabim mestima, uslovljavajući manji broj mikro pražnjenja u završnim etapama procesa i porast njihovih površina poprečnih preseka.

- Procenat aktivne površine istovremeno izložen događajima mikro pražnjenja takođe raste u početku PEO procesa, dostiže svoj maksimum a potom naglo opada. Za aluminijum, u toku anodizacije na $25 \mathrm{~mA} / \mathrm{cm}^{2}$, taj procenat iznosi $\sim 2.5 \%$ i dostiže se u privih 1.5 min procesa. Procenat oksidne površine istovremeno izložen događajima mikro pražnjenja u slučaju tantala (anodizacija na $70 \mathrm{~mA} / \mathrm{cm}^{2}$ ) najveći je posle 2.5 minuta od početka PEO procesa $(\sim 5 \%)$ i potom kao i kod ostalih metala, monotono opada. Titanijum pri anodizaciji na $150 \mathrm{~mA} / \mathrm{cm}^{2}$, karakterišu nešto više vrednosti maksimalnog procenta aktivne površine $(\sim 8 \%)$ i to 1 minut od početka PEO procesa. PEO proces na magnezijumu, pri anodizaciji od $100 \mathrm{~mA} / \mathrm{cm}^{2}$ pokazuje slično ponašanje i 2 min nakon anodizacije, procenat aktivne površine iznosi $\sim 6 \%$.

- Sa porastom vremena PEO procesa broj kanala za pražnjenje se smanjuje, dok njihov dijametar raste, što je u korelaciji sa rezultatima analize PEO procesa $u$ realnom vremenu. Uočava se prisustvo pukotina i kanala na mestima gde su se lokalizovala mikro pražnjenja i lokalno razvijale visoke temperature za vrlo kratko vreme. Pošto se broj mikro kanala za pražnjenje smanjuje, a njihov dijametar raste, javljaju se neuniformnosti na površini oksidnog sloja, što dovodi do povećanja hrapavosti. 
- EDS analiza sastava površina dobijenih oksidnih slojeva za tri metala (titanijum, aluminijum i tantal) pokazuje da su glavni elementi detektovani na površini metala koji se izlaže PEO tretmanu kiseonik i volfram. U svim eksperimentima potvrđeno je da sadržaj volframa na površini raste sa trajanjem PEO procesa, dok sadržaj metala koji potiče od substrata opada. Kako se elementi iz elektrolita ugrađuju u toku PEO procesa u spoljnji sloj oksidne površine, to i sadržaj volframa raste. Elementarni sastav površine oksidnih slojeva na titanijumu u WPA je isti kao kod slojeva dobijenih $\mathrm{u}$ WSiA, osim što u slučaju PEO procesa u WPA odnos volframa, titanijuma i kiseonika ostaje skoro konstantan. Dva su razloga zašto se to dešava. Prvi je što su prezentovani EDS rezultati integralni, odnosno predstavljaju elementarni sastav cele površine. Drugo, WPA je jača heteropoli kiselina od WSiA i rastvara dobijene oksidne površine mnogo više nego WSiA. To dovodi do povećanja dijametra kanala za pražnjenje oksidnih slojeva dobijenih u WPA u odnosu na slojeve dobijene u WSiA, odnosno do manje brzine rasta oksidnog sloja. Posledica toga je skoro konstantan elementarni sastav površina oksidnih slojeva dobijenih u WPA. Pokazano je i da je sadržaj aluminijuma i volframa mnogo veći u kanalima za pražnjenje nego u okolini kanala. Sadržaj kiseonika se može smatrati konstantnim u poređenju sa sadržajem metala.

- Oksidni slojevi su delimično kristalizovani i uglavnom se sastoje iz odgovarajućih oksida metala. Oksidni slojevi formirani na aluminijumu se sastoje iz kristala $\gamma-\mathrm{Al}_{2} \mathrm{O}_{3}$ i $\mathrm{WO}_{3}$. Na titanijumu su detektovani oksidi $\mathrm{WO}_{3} \mathrm{i}$ $\mathrm{TiO}_{2}$ (anatas), dok su na površinama oksidnih slojeva formiranih na tantalu pronađene kristalne faze $\mathrm{Ta}_{2} \mathrm{O}_{5}, \mathrm{WO}_{3}$ i $\mathrm{SiO}_{2}$.

- Ramanovi spektri oksidnih slojeva aluminijuma, titanijuma i tantala su slični referentnom Ramanovom spektru WSiA izložene termalnom tretmanu na 550 ${ }^{\circ} \mathrm{C}$. Iz ovoga možemo zaključiti da su se tokom PEO procesa formirale odgovarajuće bronze tipa $\mathrm{ReO}_{3}$ sa karakterističnim istežućim vibracionim trakama (W-O-W) na $805 \mathrm{~cm}^{-1}$ i $706 \mathrm{~cm}^{-1}$ i savijajućom trakom na $273 \mathrm{~cm}^{-1}$. Vibraciona traka na $1000 \mathrm{~cm}^{-1}$ pripisuje se istežućim vibracijama Si-O sistema. 
- Sve detektovane linije u optičko emisionim spektrima u toku PEO procesa pripadaju ventilnim metalima i jonskim i atomskim elementima prisutnim u elektrolitu. Najintenzivnije linije elemenata iz elektrolita koje se mogu detektovati u optičko emisionim spektrima pripadaju Balmerovoj seriji za vodonik $\mathrm{H}_{\alpha}$ na $656.28 \mathrm{~nm} \mathrm{i}_{\beta}$ na $486.13 \mathrm{~nm}$, kao i linije $\mathrm{K}$ I na $766.57 \mathrm{~nm}$ i $769.94 \mathrm{~nm}, \mathrm{Na}$ I na $588.99 \mathrm{~nm}$ i 589.59 nm, u elektrolitima koji sadrže kalijum i natrijum. Jake linije su i O I na $777.19 \mathrm{~nm}, 777.42 \mathrm{~nm}, 777.54 \mathrm{~nm}$, i tri O I linije na $844.62 \mathrm{~nm}, 844.64 \mathrm{~nm}$ i $844.66 \mathrm{~nm}$. U optičko emisionim spektrima može se uočiti i mnogo slabih linija O II, W I i vodonikova linija $\mathrm{H}_{\gamma}$ na 434.05 nm. U toku PEO procesa na aluminijumu i magnezijumu mogu se uočiti emisione linije koje potiču od substrata. Jake linije Al I na $394.40 \mathrm{~nm}$ i $396.15 \mathrm{~nm}$, kao i triplet Al II na $705.20 \mathrm{~nm}, 705.67 \mathrm{~nm}$ i $706.38 \mathrm{~nm}$ se javljaju prilikom PEO procesa na aluminijumu. Kod magnezijuma se javljaju sledeće linije: $\mathrm{Mg}$ I na $383.23 \mathrm{~nm}$ i $383.83 \mathrm{~nm}, \mathrm{Mg}$ II na $448.11 \mathrm{~nm}$ i $448.13 \mathrm{~nm}$, kao i Mg I na $516.73 \mathrm{~nm}, 517.27 \mathrm{~nm}$ i $518.36 \mathrm{~nm}$. Prilikom PEO procesa na titanijumu i tantalu se ne mogu zapaziti linije koje potiču iz substrata. Najverovatnije je ovo posledica mnogo više temperature topljenja tantala $\left(\sim 3000{ }^{\circ} \mathrm{C}\right)$ i titanijuma $\left(\sim 1668{ }^{\circ} \mathrm{C}\right)$ u odnosu na aluminijum $\left(660{ }^{\circ} \mathrm{C}\right)$ i magnezijum $\left(650^{\circ} \mathrm{C}\right)$.

- Pored jasno izraženih atomskih i jonskih linija, u optičko emisionom spektru PEO procesa na magnezijumu, jasno je vidljiva i vibraciona traka $\mathrm{MgO}$ koja odgovara elektronskom prelazu sa pobuđenog $\mathrm{B}^{1} \Sigma^{+}$nivoa na osnovni elektronski nivo $\mathrm{X}^{1} \Sigma^{+}$. U spektru PEO procesa na aluminijumu opaža se jaka vibraciona traka $\mathrm{AlO}$ sistema koja odgovara elektronskom prelazu sa pobuđenog $\mathrm{B}^{2} \Sigma^{+}$nivoa na osnovni elektronski nivo $\mathrm{X}^{2} \Sigma^{+}$.

- U slučaju PEO procesa na aluminijumu i magnezijumu, koristeći spektroskopske podatke dobijene za $\mathrm{AlO}, \mathrm{OH}$ i $\mathrm{MgO}$ trake, uz primenu kvantno-mehaničkih proračuna, određene su temperature plazme. Iz vibracionih traka $\mathrm{MgO}$ procenjeno je da su temperature plazme (11000 \pm 2000) K, dok su u slučaju podataka iz $\mathrm{OH}$ trake dobijene nešto niže vrednosti temperature $(3500 \pm 500) \mathrm{K}$. Iz analiza vibracione trake AlO u slučaju PEO procesa u limunskoj kiselini procenjena temperatura je $(8000 \pm 2000) \mathrm{K}$. 
- Za merenje elektronskih koncentracija korišćena je Balmerova linija $\mathrm{H}_{\beta}$. Balmerova linija $\mathrm{H}_{\alpha}$ je veoma jaka $u$ toku PEO procesa $\mathrm{i}$ jako samoapsorbovana. Iz tog razloga $\mathrm{H}_{\alpha}$ linija nije pogodna za pouzdanu analizu oblika spektralnih linija. Slaba Balmerova linija $\mathrm{H}_{\gamma}$ u PEO procesu interferira sa O II linijama i takođe nije pouzdana za analizu. Oblik $\mathrm{H}_{\beta}$ linije, dobijen u toku PEO procesa na titanijumu i tantalu, se može pouzdano fitovati samo sa dva Lorencova profila. Iz poluširina fitovanih linija su dobijene dve elektronske koncentracije od $\sim 0.8 \cdot 10^{15} \mathrm{~cm}^{-3} \mathrm{i} \sim 2.1 \cdot 10^{16} \mathrm{~cm}^{-3}$. Ove dve elektronske koncentracije su bliske odgovarajućim elektronskim koncentracijama dobijenim iz spektralne analize $\mathrm{H}_{\beta}$ linije $\mathrm{u}$ toku PEO procesa na aluminijumu.

Predstavljeni rezultati pokazuju da tehnika plazma elektrolitičke oksidacije može biti uspešno korišćena sa ciljem poboljšanja osobina ventilnih metala. Detektovanjem osnovnih paramatera PEO procesa (temperatura plazme, elektronska gustina, distribucija mikro pražnjenja i aktivna površina) i karakterizacijom dobijenih oksidnih slojeva (morfologija, hrapavost, mikro tvrdoća, hemijski i fazni sastav) identifikovani su parametri koji utiču na mogućnost dalje primene ove metode. Dobijeni rezultati omogućavaju neposrednu primenu plazma elektrolitičke oksidacije ventilnih metala $u$ fotokatalizi, zaštiti od korozije i biomedicini. Neka od ovih istraživanja su već u toku. 


\section{LITERATURA}

[1] H.I. Wu, Y.L. Cheng, L.L. Li, Z.H. Chen, H.M. Wang, Z. Zhang, Appl. Surf. Sci. 253(2007) 9387.

[2] P. Bala Srinivasan, C. Blawert, W. Dietzel, Mater. Sci. Eng. A 494 (2008) 401.

[3] F. Monfort, A. Berkani, E. Matykina, P. Skeldon, G.E. Thompson, H. Habazaki, K.Shimizu, Corros. Sci. 49 (2007) 672.

[4] J. A. Curran, H. Kalkanci, Y. Magurova, T.W. Clyne, Surf. Coat. Technol. 21 (2007) 8683.

[5] E. Matykina, R. Arrabal, P. Skeldon, G.E. Thompson, Acta Biomater. 5 (2009) 1356.

[6] G. A. Markov, V.V. Tatarchuk, M.K. Mironova, Ser. Khim. Nauk, 37 (1983) 34.

[7] H. J. Song, S. H. Park, S.H. Jeong, Y. J. Park, J. Mater. Process. Technol.209 (2009) 864.

[8] A. Da Forno, M. Bestetti, Surf. Coat. Technol. 205 (2010) 1783.

[9] P. Angerer, N. Kiss, Ch. Löcker, A. Gavrilović, W. Artner, N. Godja, G.E. Nauer, Surf. Coat. Technol. 153 ( 2002) 276.

[10] V. Samsonov, M. Hiterer, US Pat. 5, 616, 229, Apr.1, 1997.

[11] A. Yerokhin, A.A. Voevodin, R. D. Schmertzler, US Pat. 5,720,866, Feb. 24, 1998.

[12] E.L. Schmeling, B. Roschenbleck, M.H. Weidemann, US Pat. 4,978,432, Dec. 18, 1990.

[13] D.E. Bartak, B.E. Lemieux, E.R. Woolsey, US Pat. 5,264,113, Nov. 23, 1993.

[14] A.L. Yerokhin, X. Nie, A. Leyland, A. Matthews, S.J. Dowey, Surf. Coat. Technol. 122 (1999) 73.

[15] S. Moon, Y. Jeong, Corros. Sci. 51 (2009) 1506.

[16] P. B. Srinivasan, C. Blawert, W. Dietzel, Corros. Sci. 50 (2008) 2415.

[17] J. Liang, L. Hu, J. Hao, Appl. Surf. Sci. 253 (2007) 4490.

[18] L.Xijin, L. XingYang, L. Ben Li, Appl. Surf. Sci. 257 (2011) 9135

[19] S. Stojadinovic, R. Vasilic, I. Belca, M. Petkovic, B. Kasalica, Z. Nedic, Lj. Zekovic, Corros. Sci. 52 (2010) 3258.

[20] V.S. Rudnev, I.V. Lukiyanchuk, V.V. Kon'shin, P.S. Gordienko, Rus. J. Appl. Chem.75 (2002) 1082.

[21] V.S. Rudnev, Prot. Met. 44 (2008) 263.

[22] D.G. Barton, S.L. Soled, E. Iglesia, Top. Catal. 6 (1998) 87. 
[23] M.R. Bayati, H. Zargar, R. Molaei, F. Golestani-Fard, E. Kajbafvala, S. Zanganeh, Colloids Surf. A 355 (2010) 187.

[24] U.B. Mioc, M.R. Todorovic, M. Davidovic, Ph. Colomban, I. Holclajtner-Antunovic, Solid State Ionics, 176 (2005) 3005.

[25] U.B. Mioc, M. Davidovic (Eds.), Fast Proton-Ion Transport Compounds, Transworld Research Network, Kerala, India, 2010.

[26] U.B. Mioc, R. Dimitrijevc, M. Davidovic, Z. Nedic, M. Mitrovic, Ph. Colomban, J. Mater. Sci. 29 (1994) 3705

[27] U.B. Mioc, R.Z. Dimitrijevi , M.M. Mitrovic, Z.P. Nedic, J. Serb. Chem. Soc. 60 (1995) 959.

[28] N. Nakamoto, Infrared and Raman Spectra of Inorganic and Coordinated Compounds, third ed., Wiley, New York, 1978, USA.

[29] C.L. Hill (Ed.), Polyoxometalates Chem. Rev. 98 (1998) 1.

[30] M.T. Pope, A. Müller, Polyoxometalate Chemistry from Topology via Self-Assembly to Applications, Kluwer Academic Publishing, Dordrecht, 2001, The Netherlands.

[31] A.L. Yerokhin, A. Leyland, A. Matthews, Appl. Surf. Sci. 200 (2002) 172

[32] A.L. Yerokhin, L.O Snizhko, N.L. Gurevina, A.Leyland, A. Pilkington, A. Matthews, J.Phys.D: Appl. Phys. 36 (2003) 2110.

[33] R.O. Hussein, X. Nie, D.O. Northwood, A.L. Yerokhin, A Matthews, J. Phys. D: Appl, Phys. 43 (2010) 105.

[34] R.O. Hussein, X. Nie , D.O. Northwoo, Surf. Coat. Technol. 205 (2010)1659.

[35] S. Ikonopisov, Electrochim. Acta 22 (1977) 1077.

[36] J. Montero, M. Fernandez, J.M. Albella, Electrochim. Acta. 32 (1987) 171.

[37] V. I. Tchernenko, L. A. Snezhko, I. I. Papanova, Coatings by Anodic Spark Electrolysis, Khimiya, Leningrad, 1991, Russia.

[38] G. I. Skanavi, Physics of Dielectrics. Strong Fields, Izdatelstvo Fiz.-Mat. Literatury, Moscow, 1958, Russia.

[39] T. B. Van, S.D. Brown, G.P. Wirtz, Am. Ceram. Soc. Bull. 56 (1977) 563.

[40] X. Nie, Q. K. Hao, J. M. Wei, J. Wuhan Univ. Technol 11 (1996) 28.

[41] S. S. Kutateladze, Fundamentals of Heat Exchange Theory, Atom- Izdat, Moscow, 1979, Russia.

[42] A. Gunterschultze, H. Betz, Electrolytkondensatoren, Krayn, Berlin, 1937, Germany. 
[43] D. Yu. Kharitonov, E. I. Gutsevich, G. I. Novikov, A. A. Fridman, On Mechanism of Pulsed Electrolytic Spark Oxidation in Saturated Sulfuric Acid, TsNIIAtomInform, Moscow, 1988, Russia.

[44] G.A. Markov, V.V. Tatarchuk, M.K. Mironova, 1983 Izvest.SO AN SSSR. Ser. Khim. Nauk 3 34, Russia.

[45] S. Ikonopisov, A. Girginov, M. Machrova, Electrochim. Acta 24 (1979) 451.

[46] N. Klein, Thin Solid Films 50 (1978) 223.

[47] J. M. Albella, I. Montero, J. M. Martinez-Duart, Electrochim. Acta 32 (1987) 255.

[48] Zhukov M F, Dandaron G-N B, Zambalaev Zh Zh and Fedotov V A 1984 Izvest. SO AN SSSR. Ser. Techn. Nauk 4 100, Russia.

[49] V.V. Bakovets, O.V. Polyakov, I.P. Dolgovesova 1991 Plasma Electrolytic Anode Treatment of Metals, Novosibirsk: Nauka, Russia.

[50] A.V. Epelfeld, V.B. Lyudin, O.N. Dunkin, O.S. Nevskaya, Bull. Russ. Acad. Sci. Phys. $64(2000) 610$.

[51] W. Krysmann, P. Kurze, K.H. Dittrich, H.G. Schnieder, Cryst. Res. Technol. 19 (1984) 973.

[52] Yu.V. Magurova, A.V. Timoshenko, Zashch. Met. 31 (1995) 414,.

[53] A. Hickling, M.D. Ingram, Trans. Faraday Soc. 60 (1964) 783.

[54] N. M. Gegechkori, Sov. J. Exp. Tech. Phys. 21 (1951) 493.

[55] V. A. Fyedorov, B. B. Belozerov, N. D. Velikoselskaya, Fiz. Khim. Obrab. Mater. (1) (1991) 87.

[56] C. Blawert, W. Dietzel, E. Ghali, G. Song, Adv. Eng. Mater. 8 (2006) 511.

[57] P.S. Gordienko, S.V. Gnedenkov, Micro Arc Oxidation of Titanium and its Alloys, Dalnauka, Vladivostok, 1997, Russia.

[58] V. I. Tchernenko, L. A. Snizhko, I. I. Papanova, Coatings Khimiya, Leningrad, 1991, Russia.

[59] P. S. Gordienko, Coating Formation on Anodically Polarised Electrodes at the Potentials of Sparking and Breakdown, Dal- nauka, Vladivostok, 1996, Russia.

[60] A.L. Yerokhin, V.V. Lyubimov, R.V. Ashitkov, Fiz. Khim. Obrab. Mater. 5 (1996) 39.

[61] P. Kurze, W. Krysmann, G. Marx, Z. Wiss, Tech. Hochsch. Karl-Marx-Stadt. 24 (1982) 139.

[62] E.V. Koroleva, G.E. Thompson, G. Hollrigl, M. Bloeck, Corr. Sci. 41 (1999) 1475. 
[63] J.R. Morlidge, P. Skeldon, G.E. Thompson, H. Habazaki, K. Shimizu, G.C. Wood, Electrochim. Acta. 44 (1999) 2423.

[64] D.D. Macdonald, M. Urquidi-Macdonald, J. Electrochem. Soc.137 (1990) 2395.

[65] G.E. Thompson, P. Skeldon, K. Shimizu, G.C. Wood, Philos. Trans. R. Soc. Lond. A $350(1995) 143$.

[66] H.Y. Zheng, Y.K. Wang, B.S. Li, G.R. Han, Mater. Lett. 59 (2005) 139.

[67] S. Pengpeng, Yi Lu, Y. Yi , J. Xiaoyan, Z. Milin, Surf. Coat. Technol. 205 (2011) 4500.

[68] Y.J. Guan, Y. Xia, F.T. Xu, Surf. Coat. Technol. 202 (2008) 4204.

[69] J.M. Wheeler, C.A. Collier, J.M. Paillard, J.A. Curran, Surf. Coat. Technol. 204 (2010) 3399

[70] Y. J. Guan, Y. Xia, G. Li, Surf. Coat. Technol. 202 (2008) 4602.

[71] A. Ghasemi, V.S. Raja, C. Blawert, W. Dietzel, K.U. Kainer, Surf. Coat. Technol. 202 (2008) 3513.

[72] R. Arrabal, E. Matykina, F. Viejo, P. Skeldon, G.E. Thompson. Corros. Sci. 50 (2008) 1744.

[73] C.E. Barchiche, D. Veys-Renaux, E. Rocca, Surf. Coat. Technol. 205 (2011) 4243.

[74] R. Arrabal, E. Matykina, T. Hashimoto, P. Skeldon, G.E. Thompson, Surf. Coat. Technol. 203 (2009) 2207.

[75] G. Rapheal, S. Kumar, C. Blawert, B. Narendra Dahotre, Wear, 271 (2011) 1987.

[76] A. S. Gnedenkov, S. L. Sinebryukhov, D.V. Mashtalyar, S.V. Gnedenkov, Physics Procedia, 23 (2012) 98.

[77] D. J. Shen, Y.L. Wang, P. Nash, G.Z. Xing, J. Mater. Process. Technol. 205 (2008) 477.

[78] G. Sundararajan, L. Krishna, Surf. Coat. Technol. 167 (2003) 269.

[79] J. A. Curran, T.W. Clyne. Surf. Coat. Technol. 199 (2005) 168.

[80] F. Monfort, A. Berkani, E. Matykina, P. Skeldon, G.E. Thompson, H. Habazaki, K. Shimizu, Corr. Sci. 49 (2007) 672.

[81] F. Jaspard-Mecuson, T. Czerwiec, G. Henrion, T. Belmonte, L. Dujardin, A. Viola, J. Beauvir, Surf. Coat. Technol. 201 (2007) 8677.

[82] H. Kalkanci, S. C. Kurnaz. Surf. Coat. Technol. 203 (2008) 15.

[83] F.Y. Jin, K. Wang, M. Zhu, L.R. Shen, J. Li, H.H. Hong, P.K. Chu, Mater. Chem. Phys. 114 (2009) 398.

[84] D. J. Shen, Y.L. Wang, P. Nash, G.Z. Xing, J. Mater. Process. Technol. 205 (2008) 477.

[85] J. A. Curran, T.W. Clyne, Surf. Coat. Technol. 199 (2005) 168. 
[86] W.C. Gu, G.H. Lv, H. Chen, G.L. Chen, W.R. Feng, S.Z. Yang. Mater. Sci. Eng. A 447 (2007) 158.

[87] B.H. Long, H.H. Wu, B.Y. Long, J.B. Wang, N.D Wang, X.Y. Lu, Z.S. Jin, Y.Z. Bai, J.Phys.D: Appl. Phys. 38 (2005) 3491.

[88] R. Arrabal, E. Matykina, F. Viejo, P. Skeldon, G.E. Thompson, M.C. Merino, Appl. Surf. Sci. 254 (2008) 6937.

[89] R. Arrabal, E. Matykina, P. Skeldon, G.E. Thompson, A. Pardo, J. Electrochem. Soc. 155 (2008) 101.

[90] T.H. Teh, A. Berkani, S. Mato, P. Skeldon, G.E. Thompson, H. Habazaki, K. Shimizu, Corr. Sci. 45 (2003) 2757.

[91] I. Levin, D. Brandon, J. Am. Ceram. Soc. 81 (2012) 1995.

[92] A. Boumaza, L. Favaro, J. Lédion, G. Sattonnay, J.B. Brubach, P. Berthet, A.M. Huntz, P. Roy, R. Tétot, Journal of Solid State Chemistry, 182 (2009) 1171.

[93] K. J. Morrissey, K. K. Czanderna, R. P. Merril, C. B. Carter, Ultramicroscopy 18 (1985) 379.

[94] W. Xue, Z. Deng, Y. Lai, R. Chen, J. Am. Ceram. Soc. 81 (1998) 1365.

[95] Y. Dai, Y. Wang, S.G. Greenbaum, S.A. Bajue, D. Golodnitsky, G. Ardel, E. Strauss, E. Peled, Electrochim. Acta 43 (1988) 1557.

[96] E. Matykina, A. Berkani, P. Skeldon, G.E. Thompson Electrochim. Acta 53 (2007) 1987.

[97] C. S. Dunleavy, I. O. Golosnoy, J. A. Curran, T.W. Clyne. Surf. Coat. Technol. 203 (2009) 3410.

[98] M. D. Klapkiv, H. M. Nykyforchyn, V. M. Posuvailo. Mater. Sci. 30 (1994) 333.

[99] F. Mecuson, T. Czerwiec, T. Belmonte, L. Dujardin, A. Viola, G. Henrion. Surf. Coat. Technol. 200 (2005) 804.

[100] R. O.Hussein, X. Nie, D. O. Northwood, Mater. Chem. Phys. 134 (2012) 484.

[101] G. A. Markov, V.V. Tatarchuk, M. K. Mironova, Izv. SO AN SSSR. Ser. Khim. Nauk 3 (1983) 34, Russia.

[102] P. Kurze, W. Krysmann, G. Marx, Z. Wiss, Tech. Hochsch. Karl- Marx-Stadt 24 (1982) 139.

[103] V. I. Tchernenko, L.A. Snezhko, I. I. Papanova, Coatings by Anodic Spark Electrolysis, Khimiya, Leningrad, 1991, Russia. 
[104] K. A. Naugil'nykh, N. A. Roy, Electric Discharges in Water Nauka, Moscow, 1971, Russia.

[105] J. Jovović, S. Stojadinović, N. M. Šišović, N. Konjević, Surf. Coat. Technol. 206 (2011) 24 .

[106] M. A. Gigosos, M. A. Gonzalez, V. Cardenoso, Spectrochim. Acta, Part B 58 (2003) 1489.

[107] M. Ivković, S. Jovićević, N. Konjević, Spectrochim. Acta, Part B 59 (2004) 591.

[108] J. T. Davies, J. M. Vaughan, Appl. J. 137 (1963) 1302.

[109] L.O. Snizhko, A.L. Yerokhin, A. Pilkington, N.L. Gurevina, D.O. Misnyankin, A. Leyland, A. Matthews, Electrochim. Acta 49 (2004) 2085.

[110] S. Stojadinovic, M. Peric, M. Petkovic, R. Vasilic, B. Kasalica, I. Belca, J. Radic-Peric, Electrochim. Acta 56 (2011) 10122.

[111] M.D. Saksena, G.S. Ghodgaonkar, M. Singh, J. Phys. B. At. Mol. Opt. Phys. 22 (1989) 1993.

[112] C. T. Londhe, K. Sunanda, M. D. Saksena, S.H. Behere, J. Mol. Spectrosc. 263 (2010) 178.

[113] C. Zenouda, P. Blottiau, G. Chambaud, P. Rosmus, J. Mol. Struct. (Theochem) 458 (1999) 61.

[114] E. Ryshkewitch, Oxide ceramics (New Yourk), 1960, USA.

[115] B. Kasalica, M. Petkovic, I. Belca, S. Stojadinovic, Lj Zekovic, Surf. Coat. Technol. 203 (2009) 20

[116] B.H. Long, H.H. Wu, B.Y. Long, J.B. Wang, N.D Wang, X.Y. Lu, Z.S. Jin, Y.Z. Bai, J. Phys. D: Appl. Phys. 38 (1005) 3491.

[117] L.A. Snezhko, V. I. Chernenko. N.a. Elektron. obrabotka materialov, 2 (1983) 25.

[118] S. V. Gnedenkov, O. A. Khrisanfova, A. G. Zavidnaya, S. L. Sinebrukhov, A. N. Kovryanov, T. M. Scorobogatova, P. S. Gordienko, Surf. Coat. Technol. 123 (2000) 24.

[119] O. A. Golovanova, A. M. Sizikov. N.a. Izvestiya Vuzov. Khimiya i Khimich-eskaya Tekhnologiya, 39 (1996) 85.

[120] G. A. Markov, M. K. Mironova. Microarc oxidation of aluminium and its alloys in concentrated sulfuric acid, VINITI, Novosibirsk,1988, Russia.

[121] L. A. Snizhko. N.a. In Abstracts of papers, respublikanskii nauchnotekhnicheskii seminar “Anod-88“ (Republic scientic-technical seminar“Anode-88”) page 77, Kazan, 1988. 
[122] O. P. Terleeva, V. I. Belevantsev, A. I. Slonova. Prot. Met. 39 (2003) 50.

[123] F. Monfort, A. Berkani, E. Matykina, P. Skeldon, G.E. Thompson, H. Habazaki, K. Shimizu, Corr. Sci. 49 (2007) 672.

[124] A.L. Yerokhin, A. Shatrov, V. Samsonov, P. Shashkov, A. Pilkington, A. Leyland, A. Matthews, Surf. Coat. Technol. 199 (2005) 150.

[125] X. Nie, A. Leyland, H.W. Song, A.L. Yerokhin, S.J. Dowey, A. Matthews, Surf. Coat. Technol. 116 (1999) 1055.

[126] Y. M. Kim, D.Y. Hwang, C.W. Lee, B. Yoo, D.H. Shin, Kor. J. Met. Mater. 48 (2010) 49.

[127] Y.G. Ko, S. Namgung, D.H. Shin, Surf. Coat. Technol. 205 (2010) 2525.

[128] J. Li, H. Cai, X. Xue, B. Jiang, Mater. Lett. 64 (2010) 2102.

[129] Y. K. Wang, L. Sheng, R. Z. Xiong, B. S. Li, Surf. Eng. 15 (1999) 109.

[130] T. Wei, F. Yan, J. Tian, J. Alloys. Compd. 389 (2004) 169.

[131] Y. Ma, X. Nie, D.O. Northwood, H. Hu, Thin Solid Films 469/470 (2004) 472.

[133] M. Petković, S. Stojadinović, R. Vasilić, I. Belča, Z. Nedić, B. Kasalica, U.B. Mioč, App. Surf. Sci. 257 (2011) 9555.

[134] S. Stojadinovic, R. Vasilic, M. Petkovic, Z. Nedic, B. Kasalica, I. Belca, Lj. Zekovic, Electrochem. Acta 55 (2010) 3857.

[135] W. D. Brewer, R. K. Bird, T.A. Wallace, Mater. Sci. Eng. A (1998) 243.

[136] S. C. Tjong, Y.W. Mai, Compos. Sci. Technol. 68 (2008) 583

[137] Y. Yamashita, I. Takayama, H. Fujii, T. Yamazai, Nippon. Steel. Tech. Rep. 85 (2002) 11.

[138] V. Cannillo, J. Colmenares-Angulo, L. Lusvarghi, F. Pierli, S. Sampath, J. Eur. Ceram. Soc. 29 (2009) 1665.

[139] M. Geetha, A.K. Singh, R. Asokamani, A.K. Gogia, Prog. Mater. Sci. 54 (2009) 397.

[140] D. M. Brunette, P. Tengvall, M. Textor, P. Thomsen, Material Science SurfaceScience Engineering Biological Response and Medical Applications, Berlin: Springer-Verlag, 2001, Germany.

[141] R.W. Schutz, H.B. Watkins, Mater. Sci. Eng. A 243 (1998) 305.

[142] M. Rahman, Z.G. Wang, Y.S. Wong, JSME Int. J. Ser. C 49 (2006) 11.

[143] Y.M. Wang, D.C. Jia, L.X. Guo T.Q. Lei, B.L. Jiang, Mater. Chem. Phys. 90 (2005) 128. 
[144] T. Moskalewicz, F. Smeacetto, A. Czyrska-Filemonowicz, Surf. Coat. Technol. 203 (2009) 2249.

[145] B. Feng, J.Y. Chen, S.K. Qi, L. He, J.Z. Zhao, X.D. Zhang, J. Mater. Sci. Mater. Med. $13(2002) 457$.

[146] S. Ban, S. Maruno, Biomaterials 19 (1998) 1245.

[147] T. F. Stoica, C. Morosanu, A. Slav, Thin Solid Films 516 (2008) 8112.

[148] D.G. Wang, C. Z. Chen, H. Ting, T.Q. Lei, J. Mater. Sci. Mater. Med. 19 (2008) 2281.

[149] D. J. Haders, A. Burukhin, E. Zlotnikov, R. E. Riman, Chem. Mater. 20 (2008) 7177.

[150] F.X.B. Xiao, R. F. Liu, Y.Z. Zheng, Mater. Lett. 59 (2005) 1660.

[151] S. Ban, S. Maruno, J. Biomed. Mater. Res. 42 (1998) 387.

[152] K. De Groot R. Geesink, C.P.A.T. Klein, P. Serekian, J. Biomed. Mater. Res. 21 (1987) 1375.

[153] A.L. Yerokhin, X. Nie, A. Leyland, A .Matthews, Surf. Coat. Technol. 130 (2000) 195.

[154] W. Xue, C. Wang, Z. Deng, T. Zhang, ISIJ Int. 42 (2002) 651.

[155] Y. Han, S. Hong, K. Xu, Surf. Coat. Technol. 168 (2003) 249.

[156] V.I. Kalita, Fizika Khimiya Obrab. Materialov 5 (2000) 28.

[157] G. Daculsi, O. Laboux, O. Malard, P. Weiss, J. Mater. Sci. Mater. Med., 14 (2003) 195.

[158] Yu.R. Kolobov, Yu.P. Sharkeev, A.V. Karlov, Deformatsiya Razrushenie Materialov, 4 (2005) 2 .

[159] D.G. Barton, S.L. Soled, E. Iglesia, Top. Catal. 6 (1998) 87.

[160] V. Lukiyanchuk, V.S. Rudnev, V.G. Kuryavyi, P.S. Gordienko, Russ. J. Appl. Chem. 77 (2004) 1460.

[161] V. Lukiyanchuk, V.S. Rudnev, Inorg. Mater. 43 (2007) 264.

[162] S. Stojadinovic, R. Vasilic, I. Belca, M. Petkovic, B. Kasalica, Z. Nedic, Lj. Zekovic, Corros. Sci. 52 (2010) 3258.

[163] U.B. Mioč, S. Stojadinović, Z. Nedić, Materials. 3 (2010) 110.

[164] S. Stojadinović, R. Vasilić, M. Petkovic, Lj. Zeković, Surf. Coat. Technol. 206 (2011) 575

[165] M. Klisch, J. Sol-Gel Sci. Technol. 12 (1998) 21.

[166] U. B. Mioč, R. Dimitrijević, M. Davidović, Z. Nedić, M. Mitrović, Ph. Colomban, J. Mater. Sci. 29 (1994) 3705.

[167] S. Stojadinovic, M. Tadic, I. Belca, B. Kasalica, Lj. Zekovic, Electrochim. Acta 52 (2007) 7166. 
[168] L. Wang, L. Chen, Z.C. Yan, W. Fu, Surf. Coat. Technol. 205 (2010) 1651.

[169] K. A. McKinley, N. P. Sandler, Thin Solid Films, 440 (1996) 290.

[170] R.W. Buckman, Jr. JOM. 52 (2000) 40.

[171] T. Miyazaki, H.M. Kim, T. Kokubo, C. Ohtsuki, H. Kato, T. Nakamura, Biomaterials $23(2002) 827$.

[172] Q. Lu, S. Mato, P. Skeldon, G.E. Thompson, D. Masheder, Thin Solid Films. 429 (2003) 238.

[173] W.W. Albrecht, in: P. Moller, P. Cerny, F. Saupe' (Eds.), Lanthanides, Tantalum and Niobium, Springer, Berlin, 1989, Germany.

[174] P. M. Natishan, E. McCafferty, P.R. Puckett, S. Michel, Corros. Sci. 38 (1996) 1043.

[175] R.W. Berry, P.M. Hall, M.T. Harris. Thin film technology. New York: Van Nostrand Reinhold; 1968, USA.

[176] W. D. Westwood, N. Waterhouse, P.S. Wilox. Tantalum thin films. London: Academic Press; 1975, England.

[177] F. Zernike. [Chapter 5]. In: Tamir T, editor. Integrated optics, topics in applied physics, New York: Springer; 1979, USA.

[178] W. M. Paulson, F. S. Hickernell, R. L .Davis. J. Vac. Sci. Technology. 16 (1979) 307.

[179] R.L. Davis, F.S. Hickernell, Proc. Soc. Photo-Opt Instrum. Eng. 27 (1982) 408.

[180] P. Kofstad, J. Electrochem. Soc. 109 (1962) 776.

[181] D. J. Smith, L. Young., D. J. Smith, L. Young J. Electrochem. Soc. 28 (1981) 22.

[182] S. Tanimoto, M. Matsui, K. Kamisako, K. Kuroiwa, Y. Tarui, J. Electrochem. Soc.139 (1992) 320 .

[183] P.L. Young, J. Appl. Phys. 47 (1976) 235.

[184] Z. Jung-Ying, Q. Fang, I.W. Boyd, J. Appl. Surf. Sci. 138 (1999) 320.

[185] N. Inoue, T. Ninomiya, S. Kashiwabara, J. Appl. Phys. A 69 (1999) 609.

[186] Z. Mingfei, F. Zhengwen, Y. Haijun, Z. Zhuangjian, Q. Qizong, J. Appl. Surf. Sci. 108 (1997) 399.

[187] M. Petković, S. Stojadinović, R. Vasilić, Lj. Zeković, Appl. Surf. Sci. 257 (2011) 10590.

[188] R. Dreiner, K. Lehovec, J. Schimmel, J. Electrochem. Soc. 112 (1965) 395.

[189] S. Stojadinović, J. Jovović, M. Petković, R. Vasilić, N. Konjević, Surf. Coat. Technol. 205 (2011) 5406. 
[190] I.V. Lukiyanchuk, V.S. Rudnev, V.G. Kuryavyi, D.L. Boguta, S.B. Bulanova, P.S. Gordienko, Thin Solid Films 446 (2004) 54.

[192] B.L. Mordike, T. Ebert, Mater. Sci. Eng. A 302 (2001) 37.

[193] G.L. Makar, J. Kruger, Int. Mater. Rev. 38 (1993) 138.

[194] T. Yabe, M.S. Mohamed, S. Uchida, C. Baasandash, Y. Sato, M. Tsuji, Y. Mori, J. Appl. Phys. 101 (2007) 123106.

[195] G. Song, S. Song, Adv. Eng. Mater. 4 (2007) 298.

[196] J.E. Gray, B. Luan, J. Alloys. Compd. 336 (2002) 88.

[197] A. R. Shashikala, R.Umarani, S. M. Mayanna, A. K.Sharma, Int. J. Electrochem. Sci. 3 (2008) 993 .

[198] Y. W. Song, D.Y. Shan, E. H. Han, Mater. Corros. 58 (2007) 506.

[199] S. Stojadinovic, M. Peric, J. Radic-Peric, R. Vasilic, M. Petkovic, Lj. Zekovic, Surf. Coat. Technol. 206 (2012) 2905.

[200] S. Stojadinović, R. Vasilić, M. Petković, I. Belča, B. Kasalica, M. Perić, Lj. Zeković, Electrochim. Acta 59 (2012) 354.

[201] P. N. Ghosh, P.C. Mahanty, B.C. Mukkerjee, Phys. Rev. 35 (1930) 1491.

[202] A. Lagerqvist, Ark. Mat. Aston. Fys. A 29 (1943) 1.

[203] D.S. Pešić, Proc. Phys. Soc. 76 (1960) 844.

[204] R.W.B. Pearse, A.G. Gaydon, The Identification of Molecular Spectra, Chapman and Hall, London, 1976, England.

[205] K. P. Huber, G. Herzberg, Molecular Spectra and Molecular Structure, Constants of Diatomic Molecules, Van Nostrand, New York, 1979, USA.

[206] D. S. Pešić, Proc. Phys. Soc. 83 (1964) 885.

[207] C. de Izarra, J. Phys. D: Appl. Phys. 33 (2000) 1697. 


\section{SPISAK PUBLIKACIJA IZ DOKTORSKE DISERTACIJE}

1. S. Stojadinović, R. Vasilić, M. Petković, I. Belča, B. Kasalica, M. Perić, Lj. Zeković,

"Luminescence during anodization of magnesium alloy AZ31",

Electrochimica Acta 59 (2012) 354-359.

2. S. Stojadinović, M. Perić, J. Radić-Perić, R. Vasilić, M. Petković, Lj. Zeković,

"Luminescence of the $B^{1} \Sigma^{+}-X^{1} \Sigma^{+}$band system of $\mathrm{MgO}$ during plasma electrolytic oxidation of magnesium alloy",

Surface \& Coatings Technology 206 (2012) 2905-2913.

3. M. Petković, S. Stojadinović, R. Vasilić, I. Belča, Z. Nedić, B. Kasalica, U.B. Mioč, "Preparation of silicate tungsten bronzes on aluminum by plasma electrolytic oxidation process in 12-tungstosilicic acid",

Applied Surface Science 257 (2011) 9555- 9561.

4. M. Petković, S. Stojadinović, R. Vasilić, Lj. Zeković,

"Characterization of oxide coatings formed on tantalum by plasma electrolytic oxidation in 12-tungstosilicic acid”,

Applied Surface Science 257 (2011) 10590-10594.

5. S. Stojadinović, J. Jovović, M. Petković, R. Vasilić, N. Konjević,

"Spectroscopic and real-time imaging investigation of tantalum plasma electrolytic oxidation (PEO)",

Surface \& Coatings Technology 205 (2011) 5406-5413.

6. S. Stojadinović, R. Vasilić, M. Petković, Lj. Zeković,

"Plasma electrolytic oxidation of titanium in heteropolytungstate acids",

Surface \& Coatings Technology 206 (2011) 575-581.

7. S. Stojadinović, M. Perić, M. Petković, R. Vasilić, B. Kasalica, I. Belča, J. Radić-Perić, "Luminescence of the $B^{2} \Sigma^{+}-X^{2} \Sigma^{+}$band system of AlO during plasma electrolytic oxidation of aluminum”,

Electrochimica Acta 56 (2011) 10122-10129. 
8. S. Stojadinovic, R. Vasilic, I. Belca, M. Petkovic, B. Kasalica, Z. Nedic, Lj. Zekovic, "Characterization of the plasma electrolytic oxidation of aluminium in sodium tungstate", Corrosion Science 52 (2010) 3258-3265.

9. S. Stojadinovic, R. Vasilic, M. Petkovic, Z. Nedic, B. Kasalica, I. Belca, Lj. Zekovic, "Luminescence properties of oxide films formed by anodization of aluminum in 12tungstophosphoric acid",

Electrochimica Acta 55 (2010) 3857-3863.

10. B. Kasalica, M. Petkovic, I. Belca, S. Stojadinovic, Lj. Zekovic,

"Electronic transitions during plasma electrolytic oxidation of aluminum", Surface \& Coatings Technology 203 (2009) 3000-3004. 


\section{BIOGRAFIJA}

\section{Lični podaci}

Ime i prezime: Marija M. Petković

Datum rođenja: 19.05.1982. godine

Mesto rođenja: Smederevo, Srbija

\section{Obrazovanje}

- 2001. godine maturira u Gimnaziji Smederevo na prirodno-matematičkom smeru.

- 2006. godine diplomira na Fakultetu za fizičku hemiju, Univerziteta u Beogradu sa srednjom ocenom 9,10 u toku studija i sa ocenom 10 na diplomskom radu.

- 2007. godine upisuje doktorske studije na Fizičkom fakultetu, Univerziteta u Beogradu na smeru Primenjena i kompjuterska fizika.

\section{Radno iskustvo}

- Zaposlena na Fizičkom fakultetu, Univerziteta u Beogradu, od 1. januara 2007. godine na projektima Ministarstva za obrazovanje i nauku.

- Svoj naučnoistraživački rad započinje 2007. godine u okviru međunarodnog projekta FP6 "Reinforcing nanostructure laboratory", na Katedri za Primenjenu fiziku i metrologiju.

- U periodu od 2008. do 2010. godine, radila je projektu "'Ugljenične i neorganske nanotube',

- Od 2011. godine zaposlena je na projektu ", Grafitne i neorganske nanostrukture niske dimenzionalnosti'”. 


\section{Nagrade i priznanja}

- Dobitnica priznanja Srpskog Hemijskog Društva (SHD) za 2007. godinu.

- Dobitnica nagrade Fizičkog fakulteta za najboljeg mladog istraživača za 2011. godinu.

\section{Radovi u vodećim međunarodnim časopisima}

1. B. Kasalica, M. Petković, I. Belča, S. Stojadinović, Lj. Zeković,

"Electronic transitions during plasma electrolytic oxidation of aluminum", Surface \& Coatings Technology 203 (2009) 3000-3004. [IF 2.141/2010].

2. S. Stojadinović, Z. Nedić, I. Belca, R. Vasilić, M. Petković, B. Kasalica, Lj. Zeković,

"The effect of annealing on the photoluminescent and optical properties of porous anodic alumina films formed in sulfamic acid", Applied Surface Science 256 (2009) 763-767. [IF 1.795/2010].

3. S. Stojadinovic, R. Vasilić, M. Petković, Z. Nedic, B. Kasalica, I. Belča, Lj. Zeković, "Luminescence properties of oxide films formed by anodization of aluminum in 12tungstophosphoric acid", Electrochimica Acta 55 (2010) 3857-3863. [IF 3.650/2010].

4. S. Stojadinović, R. Vasilić, I. Belča, M. Petković, B. Kasalica, Z. Nedić, Lj. Zeković,

"Characterization of the plasma electrolytic oxidation of aluminium in sodium tungstate",

Corrosion Science 52 (2010) 3258-3265. [IF 3.265/2010].

5. I. D. Belča, M. Petković, S. Stojadinović, B. Kasalica, J.S. Belča, Lj.D. Zeković, "Matrix of rectangular pores obtained by AFM nanoindentation and electrolytic oxidation of $\mathrm{Al}$ ", 
Applied Physics A: Materials Science and Processing 104 (2011) 295-299. [IF $1.765 / 2010]$.

6. S. Stojadinović, J. Jovović, M. Petković, R. Vasilić, N. Konjević, "Spectroscopic and real-time imaging investigation of tantalum plasma electrolytic oxidation (PEO)",

Surface \& Coatings Technology 205 (2011) 5406-5413. [IF 2.141/2010].

7. M. Petković, S. Stojadinović, R. Vasilić, I. Belča, Z. Nedić, B. Kasalica, U.B. Mioč,

"Preparation of silicate tungsten bronzes on aluminum by plasma electrolytic oxidation process in 12-tungstosilicic acid", Applied Surface Science 257 (2011) 9555- 9561. [IF 1.795/2010].

8. M. Sarvan, M. Perić, Lj. Zeković, S. Stojadinović, I. Belča, M. Petković, B. Kasalica, "Identification of the $\mathrm{C}^{2} \Pi-\mathrm{X}^{2} \Sigma^{+}$band system of $\mathrm{AlO}$ in the ultraviolet galvanoluminescence obtained during aluminum anodization" Spectrochimica Acta A: Molecular and Biomolecular Spectroscopy 81 (2011) 672678. [IF 1.770/2010].

9. M. Petković, S. Stojadinović, R. Vasilić, Lj. Zeković, "Characterization of oxide coatings formed on tantalum by plasma electrolytic oxidation in 12-tungstosilicic acid", Applied Surface Science 257 (2011) 10590-10594. [IF 1.795/2010].

10. S. Stojadinović, R. Vasilić, M. Petković, Lj. Zeković, "Plasma electrolytic oxidation of titanium in heteropolytungstate acids", Surface \& Coatings Technology 206 (2011) 575-581. [IF 2.141/2010].

11. S. Stojadinović, M. Perić, M. Petković, R. Vasilić, B. Kasalica, I. Belča, J. RadićPerić,

"Luminescence of the $\mathrm{B}^{2} \Sigma^{+}-\mathrm{X}^{2} \Sigma^{+}$band system of AlO during plasma electrolytic oxidation of aluminum", 
Electrochimica Acta 56 (2011) 10122-10129. [IF 3.650/2010].

12. S. Stojadinović,R. Vasilić, M. Petković, I. Belča, B. Kasalica, M. Perić, Lj.

Zeković,

"Luminescence during anodization of magnesium alloy AZ31",

Electrochimica Acta 59 (2012) 354-359. [IF 3.650/2010].

13. S. Stojadinović, M. Perić, J. Radić-Perić, R. Vasilić, M. Petković, Lj. Zeković,11

"Luminescence of the $\mathrm{B}^{1} \Sigma^{+}-\mathrm{X}^{1} \Sigma^{+}$band system of $\mathrm{MgO}$ during plasma electrolytic

oxidation of magnesium alloy",

Surface \& Coatings Technology 206 (2012) 2905-2913. [2.141/2010].

\section{Radovi u zbornicima međunarodnih konferencija}

\section{Usmena izlaganja}

1. M. Petković, S. Stojadinović, R. Vasilić, I. Belca, B. Kasalica, Z. Nedić, Lj. Zeković,

"Characterization of the plasma electrolytic oxidation of aluminium in electrolytes that produce barrier oxide films", Ninth young researchers' conference materials sciences and engineering, 2010, Belgrade, Book of abstracts, 34 .

2. M. Petković, S. Stojadinović, R. Vasilić, I. Belca, B. Kasalica, Lj. Zeković, "Characterisation of bronze surface coatings on titanium formed by plasma electrolytic oxidation in 12-tungstosilicic acid", Tenth young researchers' conference materials sciences and engineering, 2011, Belgrade, Book of abstracts, 38.

\section{Poster prezentacije}

1. S. Stojadinović, B. Kasalica, I. Belča, M. Sarvan, M. Tadić, M. Petković, Lj. Zeković,

"The effect of annealing on the galvanoluminescence spectra of barrier anodic oxide films formed in organic electrolytes", XVII Symposium on Condensed Matter Physics - SFKM 2007, Vršac 226-229. 
2. M. Petković, S. Stojadinović, R. Vasilić, I. Belča, B. Kasalica, Lj. Zeković, "Plasma electrolytic oxidation of aluminum in heteropolyacids", XVIII Symposium on Condensed Matter Physics - SFKM 2011, Belgrade, Book of abstracts, 73.

\section{Radovi u zbornicima domaćih konferencija}

\section{Usmena izlaganja}

1. S.Stojadinović, B. Kasalica, I. Belča, M. Tadić, M. Sarvan, M. Petković, D. Nikolić, Lj. Zeković,

"Uticaj temperaturnog pretretmana površine aluminijuma na galvanoluminescenciju poroznih anodnih oksidnih slojeva", LI ETRAN, Igalo, 2007, N.M1.4. 1-4.

2. S. Stojadinović, I. Belča, R. Vasilić, B. Kasalica, M. Petković, M. Tadić, M. Sarvan, Lj. Zeković,

"Fotoluminescentne karakteristike poroznih oksidnih slojeva dobijenih anodizacijom aluminijuma u sulfaminskoj kiselini”, LIII ETRAN, Vrnjačka Banja, 2009, NM 1.9-14.

3. S. Stojadinović, R. Vasilić, I. Belča, B. Kasalica, M. Petković, Z. Nedić, M. Sarvan, Lj. Zeković,

"Plazma elektrolitička oksidacija aluminijuma u elektrolitima koji sadrže volfram",

LIV ETRAN, Donji Milanovac, 2010, NM 1.1-1-4.

4. M. Petković, S. Stojadinović, R. Vasilić, I. Belča, B. Kasalica, Lj. Zeković, "Plazma elektrolitička oksidacija tantala", LV ETRAN, Banja Vrućica, 2011, NM 1.1-1-4.

\section{Radovi u domaćim časopisima}

1. M. Petković, S. Stojadinović, R. Vasilić, I. Belča, B. Kasalica, Lj. Zeković, "Plasma Electrolytic Oxidation of Tantalum", Serbian Journal of Electrical Engineering 9(1) (2012) 81-94. 
Stručna usavršavanjai kursevi

- Training course, Molecular design and computer-assisted combinatorial chemistry (ICS UNIDO), Trieste 2007. Italia. 
Прилог 1.

\section{Изјава о ауторству}

Потписани-а Марија М. Петковић

број уписа 738

\section{Изјављујем}

да је докторска дисертација под насловом

Плазма електролитичка оксидација вентилних метала

- резултат сопственог истраживачког рада,

- да предложена дисертација у целини ни у деловима није била предложена за добијање било које дипломе према студијским програмима других високошколских установа,

- да су резултати коректно наведени и

- да нисам кршио/ла ауторска права и користио интелектуалну својину других лица.

Потпис докторанда

у Београду, 24.05.2012. године

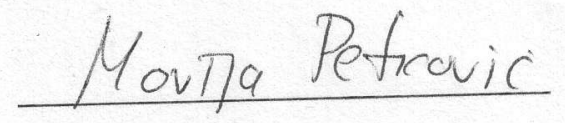




\section{Прилог 2.}

\section{Изјава о истоветности штампане и електронске верзије докторског рада}

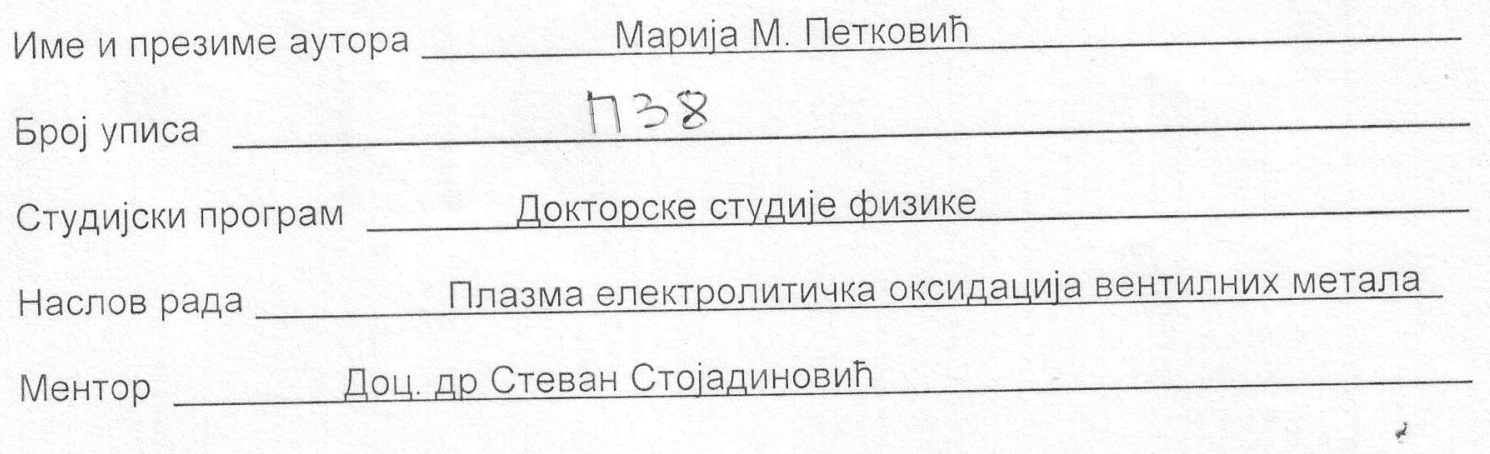

Потписани _. Марија М. Петковић

изјављујем да је штампана верзија мог докторског рада истоветна електронској верзији коју сам предао/ла за објављивање на порталу Дигиталног репозиторијума Универзитета у Београду.

Дозвољавам да се објаве моји лични подаци везани за добијање академског звања доктора наука, као што су име и презиме, година и место рођења и датум одбране рада.

Ови лични подаци могу се објавити на мрежним страницама дигиталне библиотеке, у електронском каталогу и у публикацијама Универзитета у Београду.

Потпис докторанда

У Београду, 24:05.2012.године

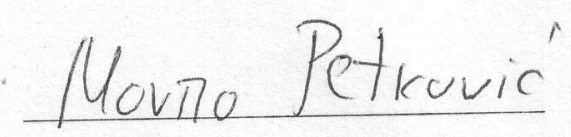




\section{Прилог 3.}

\section{Изјава о коришћењу}

Овлашћујем Универзитетску библиотеку „Светозар Марковић" да у Дигитални репозиторијум Универзитета у Београду унесе моју докторску дисертацију под насловом:

П^азма електролитичка оКсиАација вентилних мета^а

која је моје ауторско дело.

Дисертацију са свим прилозима предао/ла сам у електронском фрормату погодном за трајно архивирање.

Моју докторску дисертацију похрањену у Дигитални репозиторијум Универзитета у Београду могу да користе сви који поштују одредбе садржане у одабраном типу лиценце Креативне заједнице (Creative Commons) за коју сам се одлучио/ла.

1. Ауторство

2. Ауторство - некомерцијално

3. Ауторство - некомерцијално - без прераде

4. Ауторство - некомерцијално - делити под истим условима

5. Ауторство - без прераде

6. Ауторство - делити под истим условима

(Молимо да заокружите само једну од шест понуђених лиценци, кратак опис лиценци дат је на полеђини листа).

Потпис докторанда

у Београду, 24.05.2012. године

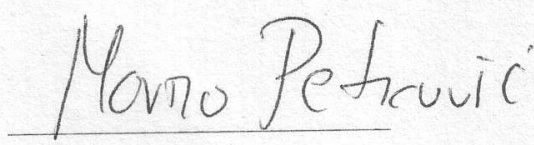

